\title{
Urban human-wildlife conflict: North Island kākā \\ (Nestor meridionalis septentrionalis) in Wellington City
}

By

Kerry E. Charles

\author{
A thesis submitted to the \\ Victoria University of Wellington \\ in partial fulfilment of the requirements \\ for the degree of \\ Master of Science in Conservation Biology.
}

Victoria University of Wellington

2013 


\section{Abstract}

Human-wildlife conflict is common wherever humans and wildlife coexist and is a growing problem in urban landscapes. Successfully mitigating conflict with wildlife requires an understanding of the ecological and social dimensions of the problem. In Wellington City, New Zealand, a human-wildlife conflict is beginning to emerge with North Island kākā (Nestor meridionalis septentrionalis:

Nestoridae), a threatened endemic parrot that was reintroduced to the city in 2002. Kākā damage property but especially damage tree bark while foraging for sap. In this thesis, I investigate the conflict with kākā using ecological, behavioural and social science approaches to understand the problem and recommend ways to mitigate the growing conflict with kākā.

To investigate tree selection for sap foraging by kākā, I sampled the characteristics, microhabitat and distribution (independent variables) of 282 trees at 15 sites across public greenspaces in Wellington City, and used model averaging to determine the relative influence of independent variables on the binary dependant variable - presence/absence of bark damage. Tree size ( $\sum \omega_{i}$ [Akaike weight] $=0.859)$ and site exposure $\left(\sum \omega_{i}=0.739\right)$ had the greatest influence on tree selection for sap feeding. Kākā were found to prefer larger

trees $\left(\bar{x} \pm\right.$ SE, DBH: $\left.\bar{x}_{\text {damaged }}=64.8 \pm 5.2 \mathrm{~cm}, \bar{x}_{\text {undamaged }}=32.9 \pm 4.5 \mathrm{~cm}\right)$ at more exposed sites. Exotic species were significantly more likely to have been damaged than native species (Fisher's exact test, $p<0.001$ ). Seven of 10 tree species damaged were exotic, and exotic conifers, such as macrocarpa (Cupressus macrocarpa) and Lawson cypress (Chamaecyparis lawsoniana) were the most commonly damaged species.

I used instantaneous scan sampling to record kākā behaviour during 25 60-100 minute observation periods at Anderson Park, Wellington Botanic Garden, and during 12 opportunistic observations of sap feeding kākā in Wellington City 
during other research activities. Forty observations of sap feeding were made and 20 sap feeding kākā identified. Based on estimated sex, females were no more likely to sap feed than males (exact binomial test $p=0.916$ ) and both adults and juveniles were observed sap feeding. Kākā were observed displacing sap-feeding conspecifics and defending sap feeding sites from tui (Prosthemadera novaeseelandiae). This indicates that sap is an important resource across sexes and life stages of kākā and is not just a supplementary food for females before breeding as previously hypothesised. Since supplementary food is provided by Karori Wildlife Sanctuary and utilised by the identified kākā, and 34\% of Wellington residents provide food and water for birds, it is unlikely that further provision of supplementary food will reduce sap feeding.

To investigate residents' attitudes and problems with birds, I hand-delivered 1030 questionnaires to households in 10 Wellington City suburbs. I then assessed the relationship between a person's attitude and their biodiversity knowledge, engagement with birds and greenspaces and experience of bird problems. An extraordinary survey return rate of $61.8 \%(n=635)$ revealed that residents had overwhelmingly positive attitudes towards native birds, despite $25 \%$ experiencing a bird problem. Planting trees to attract birds was the only predictor to provide substantial inference for attitude $\left(\omega_{i}=0.873\right)$. Experiencing a problem with birds was not an influential predictor of attitude when modelled alone $\left(\triangle \mathrm{AIC}=17.50, \omega_{i}=0.000\right)$, but when combined additively $\left(\omega_{i}=0.568\right)$ and interactively $\left(\omega_{i}=0.400\right)$ with planting to attract birds these models comprised the confidence set. Respondents who had planted to attract birds were more likely to have more positive attitudes than the rest of the population even when they reported a bird problem. Hence, attitude to birds and tolerance of problems they cause was most closely associated with a person's positive engagement with birds rather than their negative experiences. 
I also sought to understand the causes and mediators of avian-human conflict more broadly by modelling the characteristics of urban avian conflict species from the global literature to determine the characteristics that increase the likelihood of a bird species generating conflict in an urban landscape. The confidence model set from this analysis was applied to the New Zealand native avifauna already living in New Zealand's cities to generate a relative measure of each species' potential to generate conflict. Dietary breadth was the leading predictor of a species causing conflict in urban landscapes $\left(\omega_{i}=0.851\right)$, with conflict species having broader diets ( $\bar{x}=4.1 \pm 0.38$ dietary categories) than nonconflict species $(\bar{x}=3.1 \pm 0.13)$. Wide dietary breadth may allow a species to take advantage of novel and varied food sources in the urban environment, leading to increased population size and density, amplifying the problems caused by birds and exceeding residents' tolerance levels. The confidence model of conflict characteristics, comprising the variables dietary breadth, flocking, clutch size, grainivory, territoriality and non-ground nesting, identified pukeko (Porphyrio porphyria), red-billed gull (Larus scopulinus) and kākā (Nestor meridionalis) as the three New Zealand species most likely to generate conflict in urban landscapes.

Kākā damage to trees and property may increase in Wellington City and an integrated social and ecological approach to managing conflict is recommended. Monitoring should target trees most likely to be damaged by kākā, particularly large exotic conifers at exposed sites. In the long-term, the impact of kākā tree damage may be mitigated by planting tree species more resilient to damage, especially native species favoured for sap feeding. Retaining favoured sapfeeding trees in areas where they pose minimal hazard may minimise the negative impacts of bark damage. Further research is required to identify tree species resilient to bark damage, as well as repellents and aversion techniques to reduce damage to property and highly valued trees. Wellington residents, particularly those who engage with birds by planting, may be willing to tolerate problems caused by birds such as kākā. A pre-emptive approach integrating 
social and ecological strategies to facilitate tolerance but also reduce the negative impacts of damage may mitigate the emerging conflict caused by kākā in Wellington City. 


\section{Acknowledgements}

Firstly, I would like to thank my supervisor, Dr Wayne Linklater, for his support and contribution to this research project, for continually challenging me to do more and better, and for always making time to discuss and read over endless drafts (even when his daughter was merely days old!).

Thanks go to James Jones, Julian Emeny and Jeff Paris of Wellington City Council, and David Neal of Living Planet for identifying tree damage, assisting with tree identification and for valuable discussions. Thanks also to Myfanwy Emeny of Wellington City Council for supporting this research project. This research was funded by a grant to the Centre for Biodiversity and Restoration Ecology from the Parks and Gardens section of Wellington City Council.

I would also like to acknowledge the support of the Karori Sanctuary Trust, especially for providing access to data on banded kākā. Particular thanks to Raewyn Empson and Bernard Smith of Karori Sanctuary Trust for sharing their knowledge and observations.

I would like to extend particular thanks to Judi Lapsley Miller for her support and contribution to this research. Judi undertook the kākā sex analysis used in this thesis, assisted with editing and was always willing to share her knowledge, insights, observations and especially her infectious enthusiasm for the big brown budgies. Many thanks also to Linton Miller for his contributions and editing assistance.

This research could not have taken place without the contribution of the Wellington public. I thank those who responded to the household survey and to requests for kākā sightings and damage reports. I especially thank those who invited me into their homes to show me 'their' kākā (and their damage) and to share their experiences and opinions. 
Finally, I would like to acknowledge my friends and family. Many good friends, office-mates and fellow students have provided support, friendship and welcome distraction, and have helped make this journey an enjoyable one. Last, but definitely not least, special thanks and appreciation goes to my family for their unfailing love, encouragement and support. 


\section{Table of Contents}

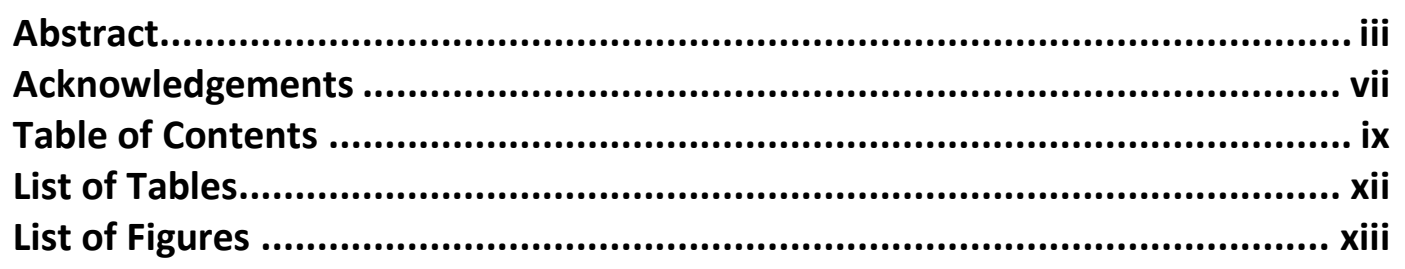

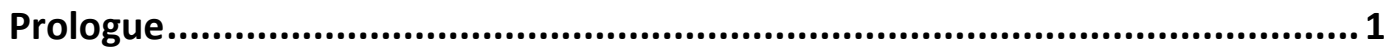

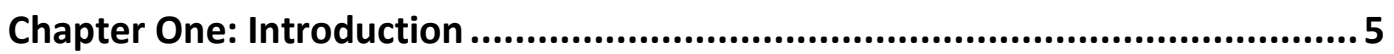

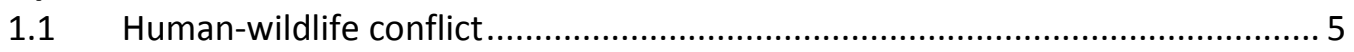

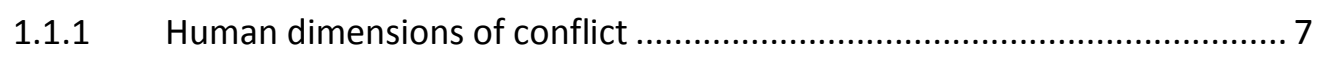

1.1.2 Human-wildlife conflict in the urban landscape ...................................... 8

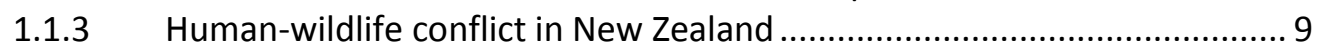

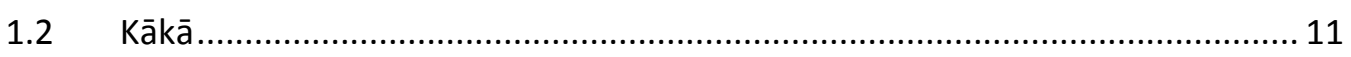

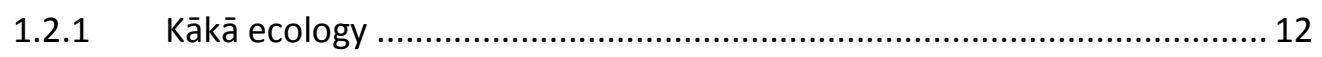

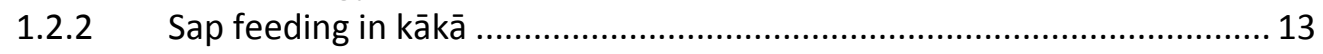

1.3 Conflict with kākā in Wellington City ........................................................... 16

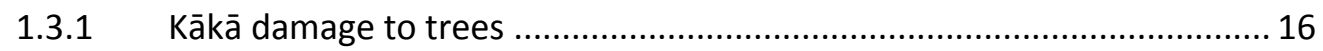

1.3.2 Other damage caused by kākā................................................................ 17

1.3.3 The emerging conflict in Wellington City ................................................ 17

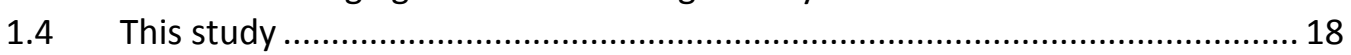

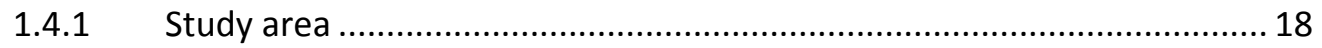

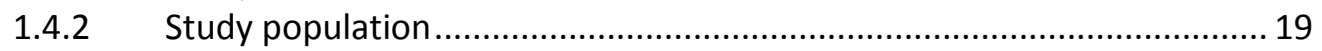

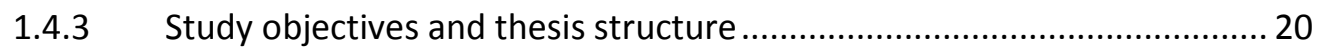

Chapter Two: Tree damage in Wellington as a result of foraging for sap and bark-dwelling invertebrates by the North Island kākā (Nestor meridionalis

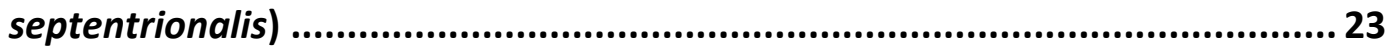

Chapter Three: The characteristics of trees selected by kākā for sap foraging . 35

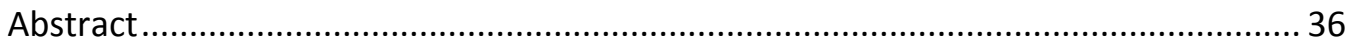

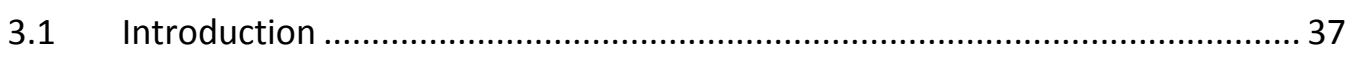

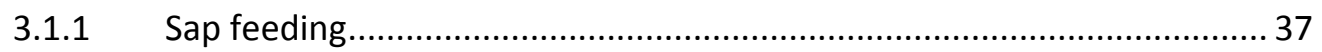

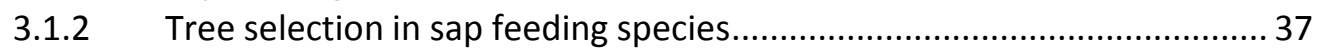

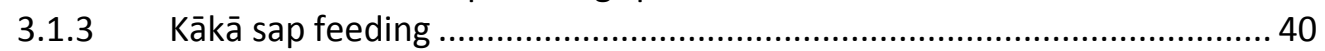

3.1.4 Kākā sap feeding in Wellington............................................................... 41

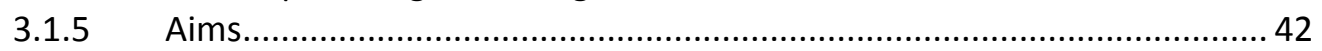

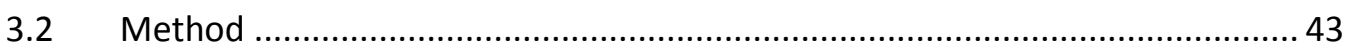

3.2.1 Kākā distribution and damage mapping ................................................ 43

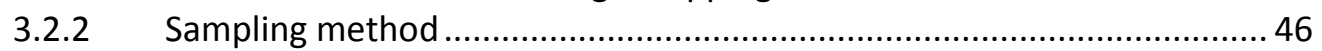

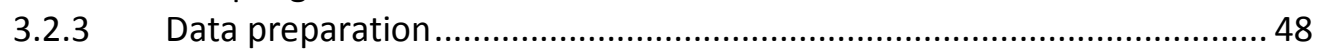




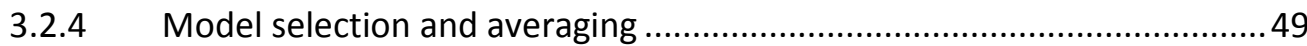

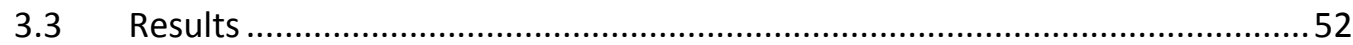

3.3.1 Description of sampled trees and sites ..............................................52

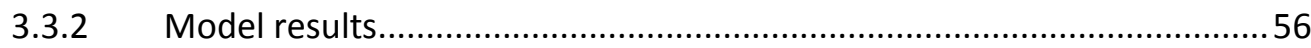

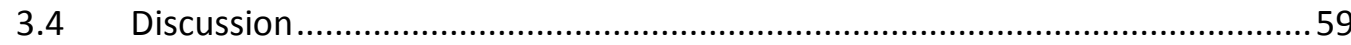

3.4.1 Characteristics of trees selected for sap feeding .....................................59

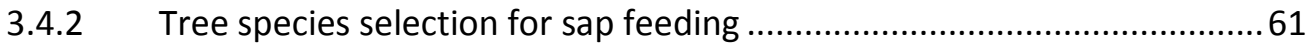

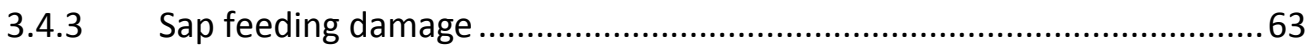

3.4.4 Limitations and further research priorities ..............................................64

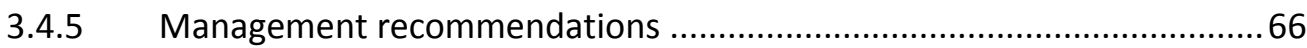

Chapter Four: Behaviour and characteristics of sap feeding kākā .................. 69

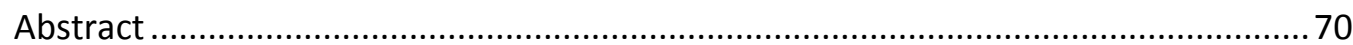

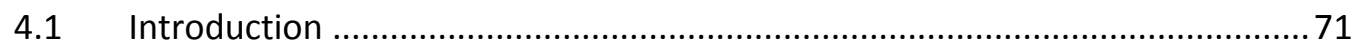

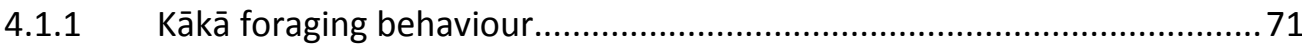

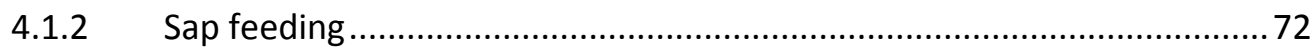

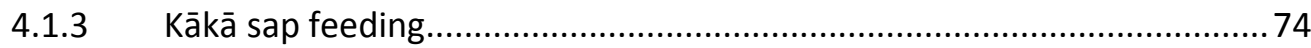

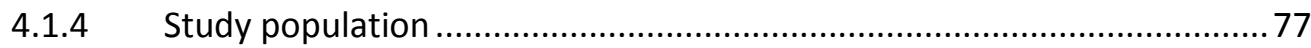

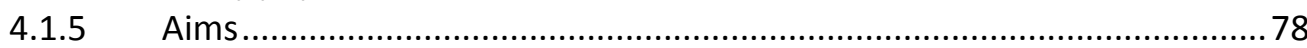

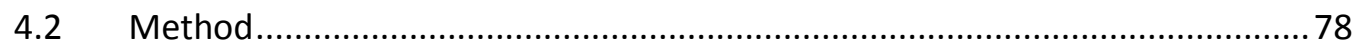

4.2.1 Observations of kākā behaviour........................................................... 78

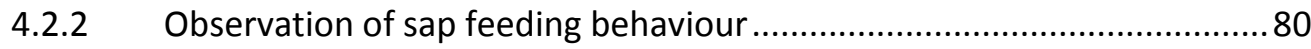

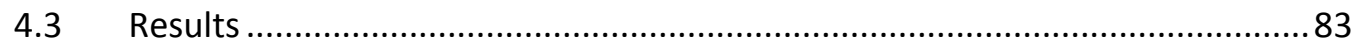

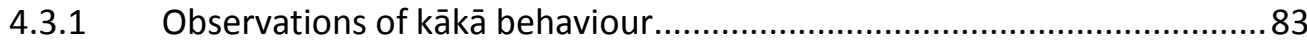

4.3.2 Observations of kākā sap feeding behaviour ................................................ 86

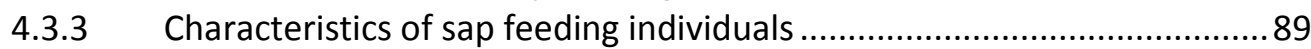

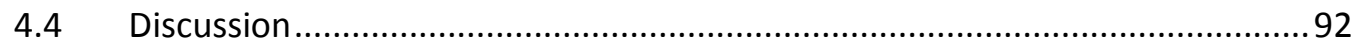

\section{Chapter Five: Tolerating, and planting for birds: Avian-human conflict in New}

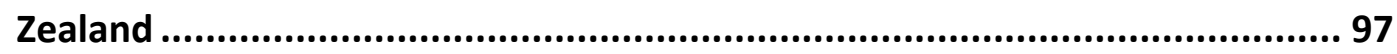

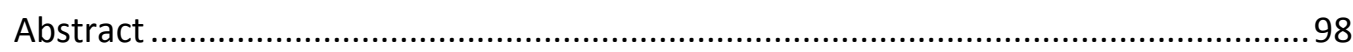

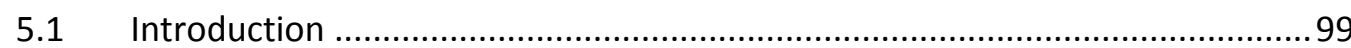

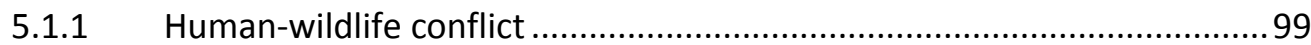

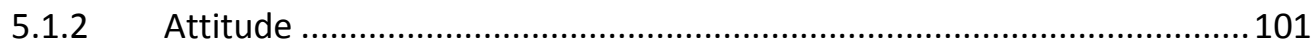

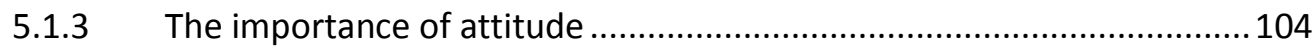

5.1.4 Human dimensions of wildlife in New Zealand ............................................ 105

5.1.5 Human dimensions of conflict with kākā .................................................. 106

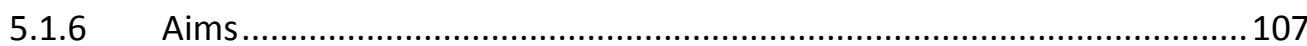

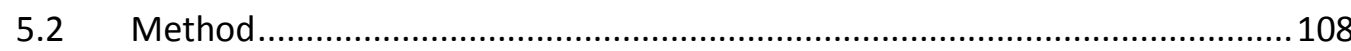

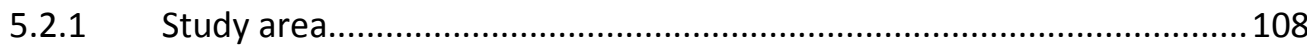

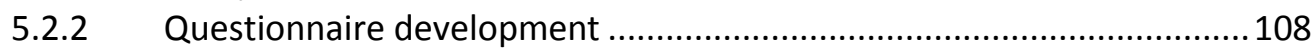

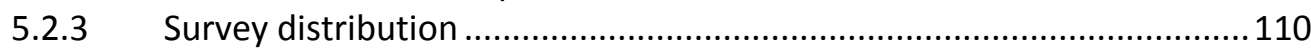

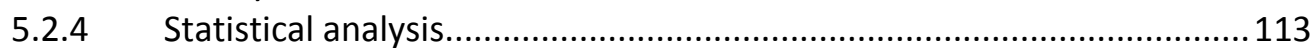

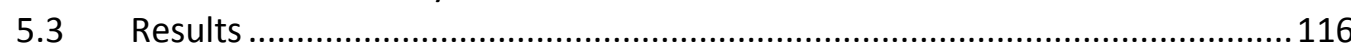

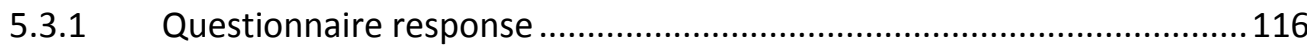




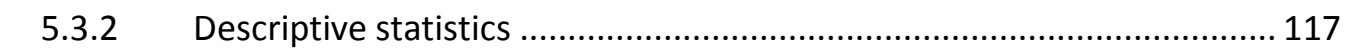

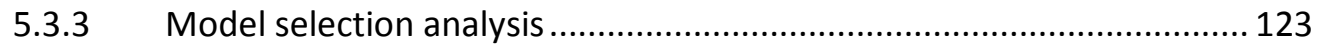

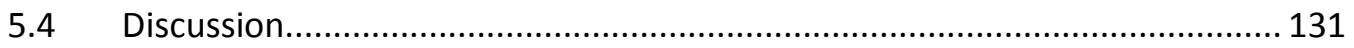

5.4.1 Experiencing bird problems ................................................................ 131

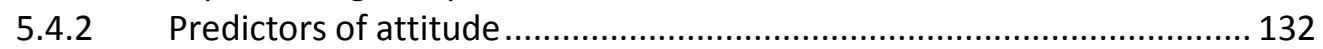

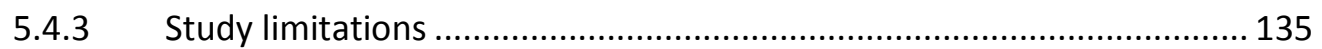

5.4.4 Management recommendations .................................................... 136

Chapter Six: Dietary breadth as a predictor of potential avian-human conflict in

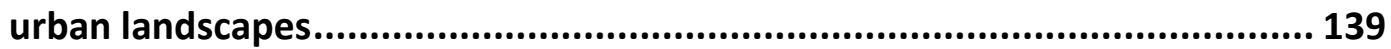

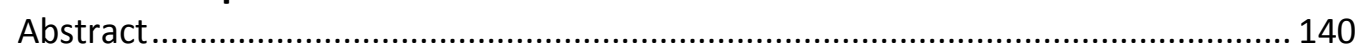

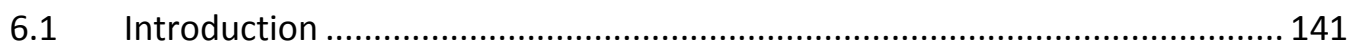

6.1.1 Potential conflict characteristics of birds.............................................. 142

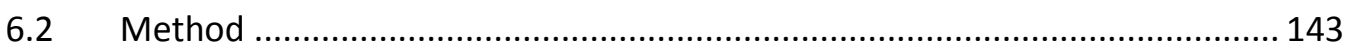

6.2.1 Literature review and species selection.............................................. 143

6.2.2 Model development and data collection .............................................. 145

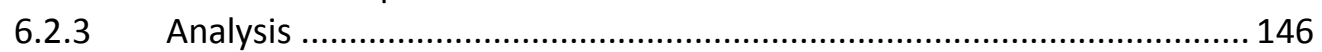

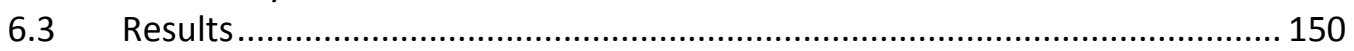

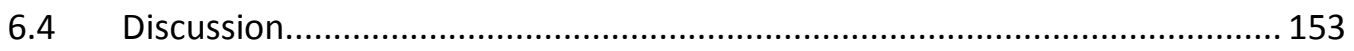

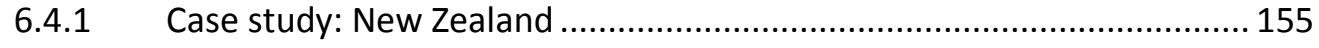

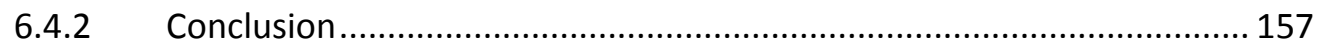

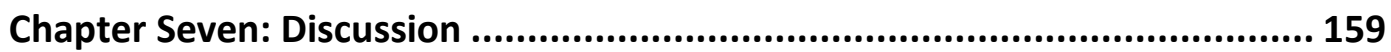

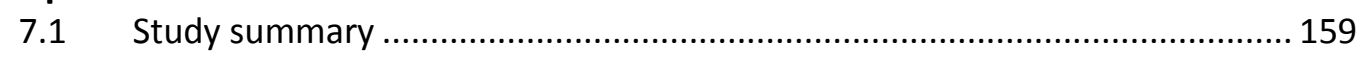

7.2 Management of urban wildlife conflict ....................................................... 163

7.3 Management recommendations .................................................................. 164

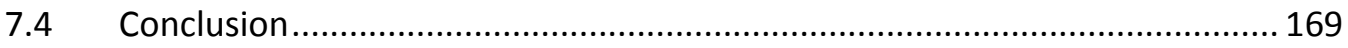

Appendix I: Correlation and association matrices ...................................... 170

Appendix II: Candidate model set for model averaging ............................. 174

Appendix III: Questionnaire .................................................................. 178

Appendix IV: Candidate model set for demographic analysis ...................... 184

Appendix V: Species list for conflict analysis............................................ 185

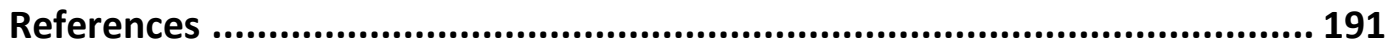




\section{List of Tables}

Table 2.1 Tree species observed to have bark damage caused by North Island Kākā (Nestor meridionalis septentrionalis) in Wellington, New Zealand.

Table 3.1 Comparison of inference provided by the global model (comprising all eight fixed-effects) with and without each of the two random-effect terms; Site/Group and Species.

Table 3.2 The number of trees of each species sampled that were observed with and without bark damage resulting from sap foraging by kākā.

Table 3.3 Summed Akaike weights of all model containing each fixed-effect. ....57

Table 4.1 Ethogram of kākā behaviour, developed from observations of kākā in trees at Wellington Botanic Garden from June to August 2012.

Table 4.2 Number and total duration of behavioural observations of kākā observed foraging for sap in Wellington between November 2011 and November 2012 90

Table 5.1 Rotated factor matrix obtained during exploratory factor analysis of the eight questions used to explore respondents' attitude to birds and bird problems.

Table 5.2 The two candidate model sets, a) 14 candidate models for the initial analysis exploring four potential predictors of attitude towards birds, and b) the 13 candidate models for the final analysis exploring the impact of experiencing a problem on the four potential predictors of attitude towards birds. 129

Table 6.1. The candidate models for conflict between humans and bird species in urban areas

Table 6.2 List of New Zealand urban bird species and their relative likelihood of generating conflict based on the confidence set of models. 152 


\section{List of Figures}

Figure 2.1 Currently known distribution of tree damage caused by North Island kākā (Nestor meridionalis septentrionalis) in Wellington, New Zealand.

Figure 2.2. Damage to Eucalyptus sp. in Wellington, New Zealand as a result of sap feeding by North Island kākā.

Figure 2.3 Damage to Thujopsis dolabrata in Wellington, New Zealand as a result of sap feeding by North Island kākā..... 28

Figure 3.1 Spatial extent of kākā in the Wellington City, developed from sightings collated from public submissions in 2010 and 2011 to the 'report-a-bird' form on the Zealandia-Karori Wildlife Sanctuary website and responses to a request for sightings published in The Dominion Post (6 March 2012) and on relevant websites and distributed via email lists and social media.

Figure 3.2 The distribution of tree damage in Wellington City identified through personal observation and reports of damage supplied by the public in response to a request published in The Dominion Post (6 March 2012) and on relevant websites, and distributed via email lists and social media

Figure 3.3 Map of Wellington City showing the location of the three groups at 15 sites at which trees were sampled and whether kākā damage was found on at least one tree in the group..

Figure 3.4 Mean $( \pm \mathrm{SE})$ of tree characteristics for trees sampled with and without bark damage. a) Diameter at breast height $(\mathrm{DBH}, \mathrm{cm})$, b) Topographic exposure (TOPEX), c) Solute value, d) Bark thickness ( $\mathrm{mm}$ ), e) Aspect (northerly or southerly), f) Minimum distance to Karori Wildlife Sanctuary fence (km), g) Anthropogenic disturbance (Distance to nearest house or road, $\mathrm{m}$ ), h) Altitude (MSL).

Figure 4.1 Locations of the six sites in Wellington City where kākā were observed sap feeding between November 2011 and November 2012, showing the number of times sap feeding was observed at the site. 
Figure 4.2 Number of minutes of each behaviour category observed during a total of 804 minutes of kākā observation over 25 days at Anderson Park, between mid-August and late-September 2012.

Figure 4.3 Percentage of observation time spent by kākā on different behaviours by kākā that fledged in the 2010/11 season (total observation time: 158 mins) and 2011/12 season (total observation time: 336 mins).

Figure 5.1 Household survey delivery locations, showing the two randomly determined start points for survey delivery (black dots) within each of the nine suburbs surveyed....

Figure 5.2 Percentage of survey respondents $(n=635)$ that, a) engaged with wildlife by planting trees to encourage birdlife or by putting food or water out for birds, b) visited public green spaces in the past year, by frequency of visitation, c) correctly identified bird species from pictures of 8 different species, and d) correctly identified the three top threats to New Zealand's native plants and animals

Figure 5.3 a) The percentage of respondents reporting a problem with birds, and the main causes of problems caused by b) all birds and c) kākā.

Figure 5.4 The distribution of responses to the eight questions exploring respondents' attitudes towards birds and bird problems.

Figure 5.5 Proportion of respondents with a positive attitude towards birds according to whether they reported having experienced a problem with birds across each of the four predictors of attitude, a) planting trees or plants to attract birds, b) greenspace visitation, c) biodiversity awareness, and d) providing supplementary foods or water for birds.

Figure 6.1 Dietary breadth, measured as the number of dietary categories consumed from, for conflict and non-conflict causing species. 


\section{Prologue}

In late 2009, bark damage on trees around Wellington City was noticed by Wellington City Council employees, particularly aborists responsible for trees in city parks and the Wellington Botanic Garden. Trees had many horizontal gouges or patches of bark removed. Although the cause of the damage was initially unknown, eventually kākā were observed causing the damage.

Kākā, extinct in the Wellington region for over 100 years, were reintroduced at Zealandia-Karori Wildlife Sanctuary in 2002. As the population grew, kākā were increasingly observed throughout inner city suburbs, and observations of tree damage also increased. A meeting was held in May 2010 to discuss the emerging problem of tree damage with representatives from organisations including the Wellington City Council, Wellington Botanic Garden, Karori Wildlife Sanctuary and the Department of Conservation. It was decided that research was needed to better understand the distribution, causes and potential management of the problem. Damage to trees, but potentially also other property, is a new cause of human-wildlife conflict in Wellington City.

When I began this study in February 2011, it was not known why kākā caused damage to tree bark. Discussions with arborists, council employees and Wellington residents generated a number of hypotheses; including that bark stripping was a play activity, that it was caused by destructive 'teenage' kākā, or that kākā were foraging for some type of food, perhaps sap or invertebrates living in tree bark.

My initial research focused on understanding the scope of the problem in Wellington City. I undertook site visits to view tree damage with Wellington City Council employees and private arborists and I visited many residents who had experienced tree or property damage from kākā. This initial research resulted in the publication of a short article in Notornis, the journal of the Ornithological 
Society of New Zealand. This publication forms Chapter Two of this thesis. In this chapter, I describe the bark damage resulting from foraging for sap and/or barkdwelling invertebrates. Since the manuscript was submitted for publication in early 2012 , further research has led me to conclude that invertebrate feeding is not a primary cause of the characteristic bark damage in the urban landscape of Wellington City and, therefore, the remainder of the thesis focuses on sap feeding.

Preliminary observations of the varied and seemingly selective distribution of tree damage led me to question how and why kākā select trees for sap feeding. This was also the primary question asked by those managing trees and parks in Wellington City and wanting to manage the future costs and risks posed by tree damage. This led to an investigation of the characteristics of trees and sites with and without bark damage to determine what influences the selection of sap feeding trees.

Little research into sap feeding by kākā had been done previously, and there was not much known about why kākā feed on sap and which birds engage in this type of foraging. The Wellington population was ideal for a behavioural study as there were a high proportion of individuals banded and of known age and sex.

From the beginning of this study, I encountered the varied and passionate opinions of those affected by kākā damage. These ranged from people with an almost obsessive dedication to feed and care for kākā, to people who were in favour of kākā population control via lethal means. Understanding the opinions, attitudes, perspectives and experiences of stakeholders is an important part of managing wildlife conflicts. Hence, I also conducted a social study considering people's attitudes to birds and experience with bird problems.

Over the course of the research, I was struck by the comparatively low levels of conflict between people and wildlife and the limited research into humanwildlife conflict in New Zealand. This was in contrast to widespread, serious and well-researched problems described in the literature from other countries. This 
led me to consider more broadly what generates human-wildlife conflict. I was curious as to whether the low levels of human-wildlife conflict in New Zealand were due to characteristics of our wildlife; predominantly birds with few large or dangerous species, or due to landscape features such as low human population density, small cities and low intensity of urbanisation. The literature analysis presented in this thesis resulted from this broader interest in urban conflict and its future in New Zealand.

The charismatic and cheeky nature of kākā and their loud distinctive calls make them a conspicuous and engaging part of the city's avifauna. Although my research has focused on the problems that kākā cause, like many residents of Wellington, I have not been able to resist being won over by their charms. It is my hope that this research will make a real contribution to ensuring that kākā continue to be appreciated and valued residents of Wellington City by enabling us to manage the problems posed by our coexistence. 


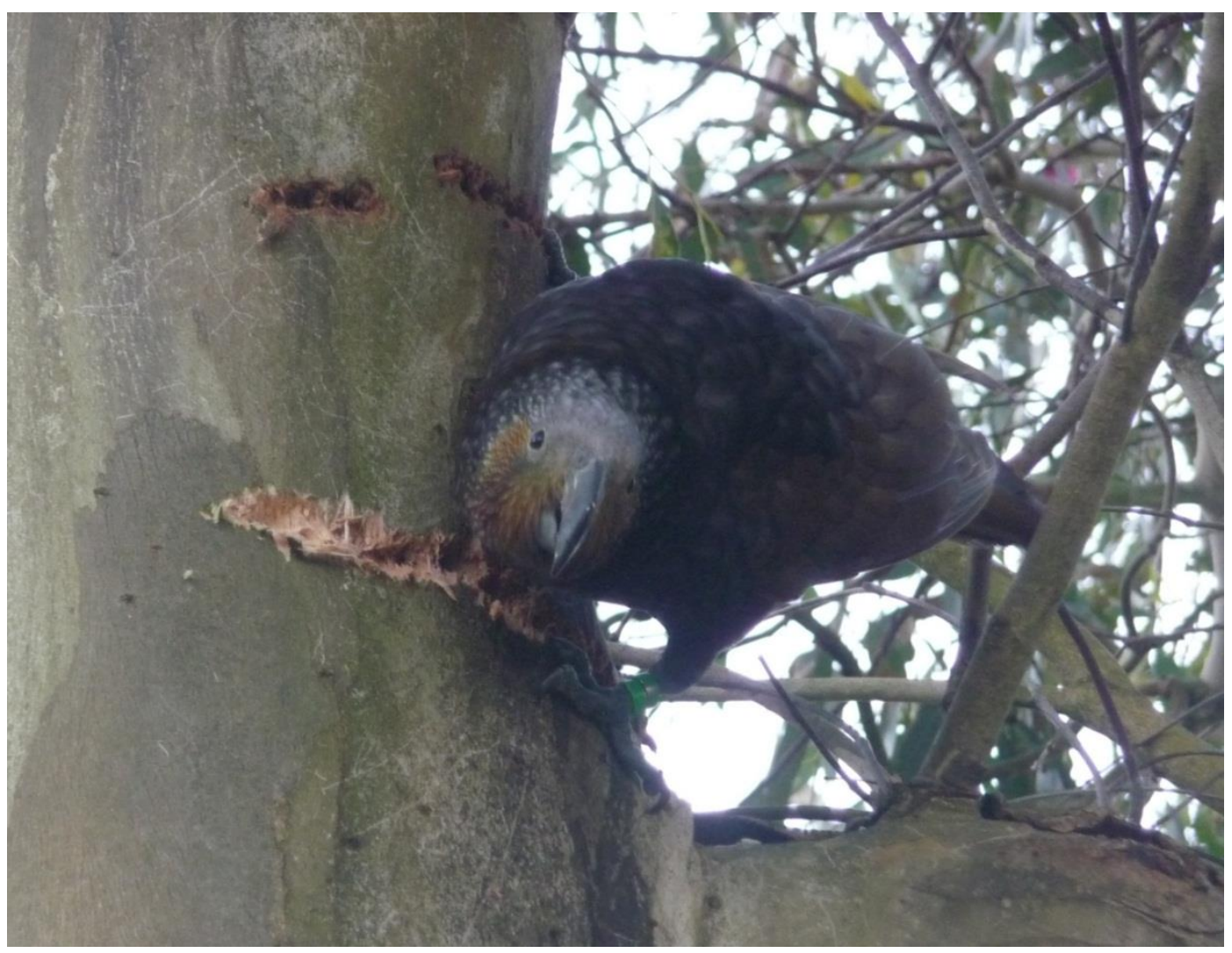

A juvenile kākā sap feeding by forming transverse gouges through the bark of Eucalyptus leucoxylon. Anderson Park, Wellington Botanic Garden, September 2012. 


\section{Chapter One: Introduction}

\subsection{Human-wildlife conflict}

Human-wildlife conflict is growing in severity and frequency worldwide (Dickman 2010) and is a common problem wherever humans and wildlife coexist (Distefano 2004). Traditionally, human-wildlife conflict was defined as a situation in which "the needs and behaviour of wildlife impact negatively on the goals of humans or when the goals of humans impact negatively on the needs of wildlife" (Madden 2004). It is increasingly recognised, however, that conflict is seldom simply the result of negative interactions with wildlife, but often represents disagreements between people over wildlife related issues (Marshall et al. 2007). This can result in complex interpersonal conflict situations in which social divisions arise from conflict with wildlife or over wildlife, or where wildlife conflicts are projections of social conflicts (Knight 2000). Conflicts between humans and wildlife and between humans about wildlife are some of the most widespread and complex issues in contemporary conservation and critically threaten the survival of many wildlife species (Dickman 2010).

Damage caused by wildlife is one of the most common sources of human-wildlife conflict (Peterson et al. 2010). A recent synthesis found that livestock and crop damage generate the most human-wildlife conflicts (Peterson et al. 2010). Damage to fisheries, gardens, buildings and other property are also common causes of conflict. Animals can also generate conflict by threatening human safety, through attacks, collisions and transmission of zoonotic disease (Conover 2001). The financial, social, psychological and public health costs of wildlife damage can be considerable and tend to be unevenly distributed across landscapes and communities (Distefano 2004). 
Conflict scenarios are rarely simple and each has its own dynamic combination of ecological, social, cultural, political and behavioural complexities (Madden 2004). Due to the complex nature of conflict, an in-depth understanding of the context, causes and consequences of a conflict situation is necessary before effective conflict management strategies can be developed (Madden 2004; Jonker et al. 2006).

Collecting baseline ecological information on the species involved in conflict is an important first step in managing human-wildlife conflicts (Treves et al. 2006). Understanding the biology, ecology and behaviour of a conflict species provides insight into the drivers of conflict and may inform the development of management strategies to reduce the negative impacts of wildlife on humans (Conover 2001). For example, research into the resource requirements and preferences of woodpeckers (Picidae spp.) in the north-eastern United States led to recommendations for housing materials to reduce property damage from these species (Harding et al. 2009). Despite the importance of research, ecological data is lacking for many conflict-causing species because gathering indepth data is time consuming, difficult and costly (Adams \& Lindsey 2010; White \& Ward 2010; Young et al. 2010) and may be seen as less important than implementing management or providing compensation (Treves et al. 2006). Failing to prioritise research, however, results in management that is poorly informed, rarely evaluated and often ineffective (White \& Ward 2010).

Traditionally, management of human-wildlife conflicts focused on reducing wildlife populations, especially the removal of problem individuals, through translocation or lethal means. Particularly in urban areas, lethal techniques are becoming increasingly unacceptable due to regulation, public opposition and safety concerns (Messmer 2009; White \& Ward 2010). Translocation is labour intensive, costly and self-limiting over time (Adams 1994). Low survival rates after translocation mean this method may be no more humane than lethal control (Massei et al. 2010). Additionally, population reduction may be an 
ineffective strategy for long term conflict mitigation as populations often rapidly return to their original size through compensatory reproduction, recolonisation and return of translocated individuals. These traditional approaches have limited effectiveness as they do not address the root causes of conflict (Carlos et al. 2009).

\subsubsection{Human dimensions of conflict}

Understanding the social, economic and political context of a conflict is equally as important as understanding the ecological context (Madden 2004; White \& Ward 2010). Research into the human dimensions of wildlife conflict is becoming increasingly common, particularly in North America and Europe (White et al. 2005; Carlos et al. 2009; Glikman et al. 2012). Human dimensions research includes consideration of people's beliefs, values, attitudes, tolerance and experiences with wildlife. Social research may also consider the impact of cultural norms and expectations, economic and political disparities and social discourse on shaping human-wildlife conflicts (Dickman 2010; Peterson et al. 2010). Investigating conflict from a social and cultural perspective provides an understanding of the diverse factors that drive people's relationships with wildlife (Dickman 2010; White \& Ward 2010) and may promote the development of more effective and socially acceptable solutions (Jonker et al. 2006; Whiting \& Miller 2008; Consorte-McCrea 2011).

Although ostensibly caused by negative interactions between humans and wildlife, many wildlife conflicts include equally important human-human conflicts between people with differing goals, attitudes, values, perspectives and levels of wealth, resource access or empowerment (Madden 2004). Hence, human-wildlife conflicts often represent human social conflicts or reflect social tensions and discontent rather than solely problems with wildlife (Knight 2000; Dickman 2010). In these cases, an understanding of the human dimensions is vital, and effective management relies on reaching compromises between 
stakeholder groups as much as it does on managing wildlife (White \& Ward 2010).

It is often assumed that there is a direct and proportional relationship between the level of damage, the level of conflict it engenders and the response provoked (Dickman 2010). However, public perceptions of a conflict problem may differ from reality and therefore, reducing the level of damage may not address the conflict (Madden 2004; Dickman 2010). Perceptions and attitudes are based not only on fact and personal experience, but also wider social experiences, cultural norms, expectations and beliefs (Kretser et al. 2009; Dickman 2010). Therefore, understanding and managing people's attitudes, perspectives and tolerance levels may be a more effective strategy than simply managing wildlife populations.

\subsubsection{Human-wildlife conflict in the urban landscape}

In recent decades, successful conservation efforts and the expansion of urban areas into wildlife habitats have led to growing animal populations in cities and an increase in urban human-wildlife conflict (Messmer 2000; Jonker et al. 2006). Wildlife species can impose a variety of costs on urban residents including damage to vegetation or property, aggressive behaviour, disturbing residents with noise, transmission of diseases and causing concern for the safety of residents or pets (Temby 2004; Peterson et al. 2010). A study carried out more than a decade ago found over $60 \%$ of urban and suburban households in the US experienced wildlife problems, resulting in a mean cost of $\$ 63$ per household per annum (Conover 1997). More recent research suggests that the incidence and severity of problems continues to grow (e.g. Temby 2004; Thornton \& Quinn 2009; Taylor et al. 2011).

The urban landscape can have dramatic effects on a species, altering behaviour, ecology, population dynamics and habitat utilisation (Ditchkoff et al. 2006; Francis \& Chadwick 2012) and this may have important consequences for management of urban conflict (Jones \& Thomas 1998). Hence, urban-specific 
ecological knowledge of the species is needed. Research undertaken in unaltered landscapes may not be directly applicable to the ecology of animals or their conflict with people in urban landscapes.

The successful management of urban wildlife conflicts may have important implications for biodiversity conservation. Direct experience with the natural world influences an individual's support for conservation (Chawla 1999; Miller \& Hobbs 2002). With the majority of the world's population now resident in cities, biodiversity conservation increasingly depends on the ability of urban residents to maintain a connection with nature through direct experience of the natural world within the urban environment (Dunn et al. 2006). Unfortunately, the wildlife and plant species encountered by urban residents largely have negative associations as pests or weeds (Dunn et al. 2006) and may cause damage, nuisance or threaten resident safety. Negative experiences with urban wildlife can have a detrimental impact on people's attitudes; altering a person's perception of wildlife (West \& Parkhurst 2002; Jonker et al. 2006), increasing their support for species control (West \& Parkhurst 2002) and reducing wider support for conservation (Naughton-Treves \& Treves 2005). Therefore, in addition to ensuring urban residents experience the natural world, it is also important that these experiences are positive or at least tolerated. Hence, management of human-wildlife conflicts is crucial to improve people's experience of urban wildlife and ensure that urban dwellers continue to value wildlife. Therefore, reducing wildlife conflicts in urban areas may play a crucial role in ensuring the economic and political support of urban residents for biodiversity conservation, both within and beyond their city.

\subsubsection{Human-wildlife conflict in New Zealand}

In comparison with many other countries, levels of wildlife conflict in New Zealand are relatively low and there has been very little study of human-wildlife conflict here. New Zealand's lack of native land mammals may contribute to this 
low level of conflict since large-bodied, conspicuous and dangerous species are particularly likely to generate conflict (Dickman 2010).

The most well-known New Zealand native species that causes conflict is the kea (Nestor notabilis). Kea damage vehicles, buildings and other property in settlements, carparks and ski fields in alpine areas of the South Island, particularly when attracted by food waste or intentionally-provisioned food (Peat 1995; Diamond \& Bond 1999). Kea will also attack sheep on high-country farms to feed on subcutaneous fat. The injuries may result in the death of the sheep from blood poisoning (Peat 1995; Diamond \& Bond 1999). These problems have resulted in conflicts with farmers, businesses, residents and visitors. Problem birds may be relocated by the Department of Conservation, but illegal killing of kea has also occurred (Kea Conservation Trust 2013a). Research is underway into methods to deter kea from investigating and destroying anthropogenic objects and to quantify the impact of kea on high-country farms (Clio Reid, pers. comm., Mussen 2012; Kea Conservation Trust 2013b).

New Zealand is one of the most highly urbanised countries in the world, with $86 \%$ of its population living in cities (Statistics New Zealand 2006a). The comparatively low levels of human-wildlife conflict in New Zealand cities is perhaps due to the relatively small size and low density of urban areas. Exotic bird species appear to be the main cause of conflicts in New Zealand urban areas, particularly when people's tolerance levels and perspectives on the acceptability of management differ. Australian magpies (Gymnorhina tibicen) may threaten and attack people (Burdon 2010) and black swan (Cygnus atratus) foul parks and lakeshores and can also be aggressive, particularly when attracted by provisioned food (Brockie 1997). A range of bird species cause problems due to noise, odour and fouling when roosting (Brockie 1997; West 2005; Krimowa 2011; Ryan 2011). Conflict with native bird species in urban areas is rare.

The only reported studies of urban conflict in New Zealand have focused on the synurbic feral rock pigeon (Columba livia) in Wellington City (Krimowa 2011; 
Ryan 2011). This species causes conflict due to fouling, public health concerns and their tendency to forage around people (Ryan 2011). Public feeding was identified as a key determinant of pigeon distribution in both studies and reducing the provision of supplementary food was recommended to reduce pigeon populations and conflict with people (Krimowa 2011; Ryan 2011).

\subsection{Kākā}

The kākā (Nestor meridionalis: Nestoridae) is a large $(38-44 \mathrm{~cm})$ parrot endemic to New Zealand (Higgins 1999). There are two subspecies, the North Island ( $N$. meridionalis septentrionalis) and the South Island (N. m. meridionalis) kākā. Both subspecies are olive-brown, with orange-yellow ear coverts, a grey forehead, and a crimson belly and under-wings (See photographs in this thesis, Higgins 1999). Kākā have a long, slender, downcurved bill, with a sharp upper mandible and a narrow, chisel-like lower mandible (Higgins 1999). The tongue has a brush-like tip (Buller 1888). Males have a similar appearance to females, with a slightly larger body and longer bill (Moorhouse et al. 1999).

Until the early $20^{\text {th }}$ century, kākā were widespread and abundant in native forests throughout mainland New Zealand (Buller 1888). In the last century, however, populations have dramatically declined and they are now common in only a fraction of their former range (Robertson et al. 2007). Predator-free offshore islands support reasonably-sized stable populations, however mainland populations are localised to large forest tracts, such as Pureora and Whirinaki Forests in the North Island, and Nelson Lakes and Westland in the South Island (O'Donnell \& Rasch 1991). The dramatic decline in mainland populations can be predominantly attributed to the impacts of introduced predators and competitors, as well as habitat loss due to forest clearance (Beggs $\&$ Wilson 1987; O’Donnell \& Rasch 1991; Wilson et al. 1998; Moorhouse et al. 2003). Introduced species such as possums (Trichosurus vulpecula) and wasps (Vespula 
spp.) compete with kākā for high-energy foods such as flowers, fruits and honeydew (Beggs \& Wilson 1991; Moorhouse 1997; Wilson et al. 1998). Introduced mammals including rats (Rattus spp.) and stoats (Mustela erminea) prey on kākā eggs, chicks and nesting females (Wilson et al. 1998; Moorhouse et al. 2003; Greene et al. 2004). Kākā populations often exhibit a strong sex ratio bias towards males due to predation of nesting females (Greene et al. 2004). Mainland populations continue to decline in areas without extensive and sustained pest control (Greene et al. 2004). Kākā are classified as nationally vulnerable by Miskelly et. al (2008) and by the IUCN as endangered with a declining population trend (IUCN 2012).

\subsubsection{Kākā ecology}

Kākā are found in a range of forest types including broadleaf, podocarp and beech forests (Higgins 1999). Adults have relatively small home ranges but will occasionally make substantial excursions outside of this core area. Males in Nelson Lakes National Park had home range sizes of up to 1600 ha (O'Donnell \& Rasch 1991) but considerably smaller home range sizes of $12.7 \pm 2.9$ ha $(\bar{x} \pm$ SE) were found in the North Island (Beaven 1996). Home range size is likely to vary across the year and may peak in spring (Beaven 1996). Kākā can be fairly localised, returning to the same position, even the same tree repeatedly throughout the year (Beaven 1996). Recently fledged kākā disperse widely, moving large distances (in some cases $>30 \mathrm{~km}$, Greene et al. 2004).

Kākā can cover large distances. Some females regularly move up to $20 \mathrm{~km}$ a day (O'Donnell \& Rasch 1991) and a juvenile has been described travelling $100 \mathrm{~km}$ in a week near Nelson (Beaven 1996). A kākā reared at Karori Wildlife Sanctuary (KWS)dispersed $100 \mathrm{~km}$ to Mt Bruce National Wildlife Centre, before returning (Miskelly et al. 2005).

Kākā have a diverse diet and a wide repertoire of foraging behaviours (O'Donnell \& Dilks 1994; Moorhouse 1997). The main components of their diet are invertebrates (particularly wood-dwelling larvae), seeds, fruits, nuts, nectar, 
honeydew and tree sap (O'Donnell \& Dilks 1989; Moorhouse 1997). Although they have a diverse diet, kākā have been described as sequential specialists (O'Donnell \& Dilks 1994) as they move between different food sources over the seasonal cycle.

Kākā are social birds, often seen in small flocks of 3-5 or up to 10 birds (van Horik 2005). Although often solitary when foraging, they may congregate in groups of up to 20 at a food source (Moorhouse 1991; Moorhouse 1997). The kākā's vocal repertoire consists of five call types, used in different spatial and social circumstances (van Horik et al. 2007).

The breeding season for kākā is between October and July (Moorhouse et al. 2003). Eggs are laid in a hollow in mature, dead or decaying trees on a bed of woodchips chewed from the cavity's walls (Powlesland et al. 2009). Usual clutch and brood sizes are four and two respectively (Moorhouse 1991) and fledglings become independent after five to six months.

Kākā are episodic breeders, nesting only in years when food is abundant (O'Donnell \& Rasch 1991; Greene et al. 2004). Timing of reproduction is closely linked to mast seeding and fruiting of particular trees (Greene et al. 2004). For example, in Big Bush in the northern South Island, breeding only occurred every 2-3 years during red beech (Nothofagus fusca) mast seeding (Wilson et al. 1998). Breeding success is also linked to food abundance in the North Island (Moorhouse 1991).

\subsubsection{Sap feeding in kākā}

Sap is an important seasonal food source for kākā (Beggs \& Wilson 1987; O'Donnell \& Dilks 1989). To obtain sap, kākā use their beak to remove bark from a trunk or branch and then lick sap from the tree's exposed cambial layer. The kākā's brush-like tongue is effective in collecting liquids such as nectar and sap (Garrod 1872). Two different techniques of sap feeding have been described; stripping bark to expose the surface cambium and the prising open of horizontal 'trapdoors' in the bark layer (O'Donnell \& Dilks 1989). 
Phloem sap is a nutrient-rich food source, comprised mainly of sucrose and other carbohydrates (Snyder 1992; Beck 2010). Sap can be low in toxins and feeding deterrents (Douglas 2006). The yellow-bellied glider, a marsupial of similar size to the kākā, can satisfy its daily energy needs relatively quickly by foraging on sap at just two or three sites on a Eucalyptus tree (Smith 1982). Hence, although removing bark is energy and time intensive, kākā may be able to satisfy their energy requirements in a short time with this foraging strategy.

Sap feeding may provide a high-energy source of food during periods when little nectar is available (Beggs \& Wilson 1987; O'Donnell \& Dilks 1989). Observations of sap feeding by kākā have predominantly occurred in late winter and early spring (O'Donnell \& Dilks 1989; Beaven 1996; Berry 1998) at a time when there is little nectar or flower sources available and energy needs are high due to cold weather (Weathers et al. 1984; O'Donnell \& Dilks 1994). Sap may also flow faster or at higher pressure in early spring so may be more easily accessible at this time of year (O'Donnell \& Dilks 1989).

Sap feeding may be a particularly important food source for female kākā (Greene et al. 2004). Only one male has previously been observed sap feeding (Beaven 1996). At Mt Bruce Reserve, in the southern North Island, only females have been observed feeding on sap, and only older females have been observed using the more specialised horizontal 'tapping' technique. Thus, sap feeding may be a learned skill that is acquired with age (Berry 1998). Sap feeding was also restricted to females on Kapiti Island (Moorhouse 1997) and the majority of sap feeding observations at Whirinaki, in the Bay of Plenty, were of female kākā (Beaven 1996). This may be because females have higher energy requirements in the lead-up to breeding (Beaven 1996). It has also been suggested that kākā may use hormonal indicators or increased nutrient content in sap to predict mast seed production (Wilson et al. 1998), and so allow synchronisation of breeding with high food availability (Moorhouse et al. 2003). 
Feeding on sap is a rare behaviour among vertebrates, probably because it is a difficult food to exploit (Snyder 1992). A few woodpecker species feed extensively on sap (Subfamily: Picinae, Tate 1973; Kozma 2010), as do yellowbellied (Petaurus australis, Goldingay 1987; Mackowski 1988) and sugar gliders (Petaurus breviceps, Smith 1982). A few species of marmoset (Family:

Callitrichidae, Coimbra-Filho \& Mittermeier 1976; Lacher et al. 1984) and squirrel (Sciurus spp., Kenward 1982; Snyder 1992) are also known to feed on sap. In addition to woodpeckers, there are few bird species that cause and maintain bark wounds in order to feed on sap. The glossy flowerpiercer (Diglossa lafresnayii, Martin et al. 2009), and the 'akiapōlā'au (a species of Hawaiian honeycreeper, Hemignathus munroi, Pejchar \& Jeffrey 2004) are the only other birds reported to cause bark wounds for sap feeding. No parrot species other than kākā have been observed producing bark wounds for sap feeding, although the crimson rosella (Platycercus elegans) has been observed maintaining the flow of sap at wounds created by the yellow-bellied glider (Chapman et al. 1999). The kākā is the only vertebrate species known to feed on sap in New Zealand.

The bark damage caused when kākā feed on sap has been observed on a range of native and exotic tree species across New Zealand. Damage has been noted in native forests in the North (Beaven 1996; Berry 1998) and South (O'Donnell \& Dilks 1989, Beggs \& Wilson 1987, Innes 1994) Islands, on Stewart Island, and a number of other offshore Islands (Innes 1980; O'Donnell 1993). Native tree species that have been observed with sap feeding damage include rata (Metrosideros spp. O’Donnell \& Dilks 1989, Berry 1998), kanuka (Kunzea ericoides, Chris Smuts-Kennedy, pers. comm.), rimu (Dacrydium cupressinum, Holloway 1948; O'Donnell 1993), matai (Prumnopitys taxifolia, Beaven 1996), tawa (Beilschmiedia tawa), mahoe (Melicytus ramiflorus, Berry 1998) and tōtara (Podocarpus totara, O'Donnell 1993; Beaven 1996). Exotic plantation and amenity trees have also been damaged at a number of sites across the mainland and on offshore islands (Beaven 1996, Innes 1994, Berry 1998). 


\subsection{Conflict with kākā in Wellington City}

\subsubsection{Kākā damage to trees}

Bark damage from kākā foraging for sap was first observed on trees in Wellington City in 2009. Damaged trees have since been observed in many inner city suburbs and on private as well as public land, including in the Wellington Botanic Garden. Tree damage is highly variable in presence and extent across sites and individual trees. In some areas, damage is located on one or a few clustered trees with surrounding trees undamaged. In other areas, large groves of trees have been damaged. Damage has not been found on trees at many other sites. A damaged tree may be covered by many hundreds of scars, or only have one or two patches of removed bark. Tree damage has been observed on a wide range of exotic and native tree species in Wellington.

There are two characteristic types of tree damage resulting from kākā sapforaging in Wellington City. The first has been observed on only a small number of species in Wellington, predominantly Eucalyptus spp., and consists of transverse gouges through the bark spaced at regular intervals along the trunk and main branches. The other damage type is characterised by patches of exposed vascular cambium where strips of bark have been peeled off the trunk and branches. This type of damage has been observed on a variety of species, particularly conifers.

Bark damage caused by kākā can significantly impact on the structural and physiological health of a tree. Damage compromises the structural integrity of the tree, leaving it vulnerable to branch failure especially during high winds (James Jones, Wellington Botanic Garden, pers. comm.). Bark damage can induce epicormic growth, rapid shoot elongation and reduced secondary growth that results in numerous weak lateral stems. Bark damage may also cause foliage browning or loss and can lead to dieback of the entire crown (Innes 1994). Bark 
removal may also increase physiological stress and susceptibility to pathogens (Beaven 1996). A California redwood (Sequoia sempervirens) felled at Wellington Botanic Garden was observed with decay that had spread deep into the branch tissue from the bark removal site.

\subsubsection{Other damage caused by kākā}

In addition to removing the bark of trees, kākā cause other vegetation and property damage in Wellington City. Residents have reported the loss of crops of fruit or nuts from trees as well as damage to buildings' joinery, guttering, cladding and chimneys. Kākā have destroyed wooden nestboxes installed to facilitate their own and other native species' breeding at Karori Wildlife Sanctuary. Exploratory and destructive behaviour may also have detrimental effects for kākā as this has led to poisoning from heavy metals or other toxins, causing death in some cases (Karori Sanctuary Trust 2012a).

Similar problems caused by sulphur-crested cockatoo (Cacatua galerita) and Little Corella (Cacatua sanguinea) in Australia provide examples of the potential for intelligent parrots to generate serious human-wildlife conflict in urban areas. Particularly when attracted by supplementary food provision, these birds damage wiring, buildings, garden furniture and solar water heating systems on rooftops (Temby 2004, 2010).

\subsubsection{The emerging conflict in Wellington City}

Since bark damage increases the likelihood of structural failure, such as branch fall, damaged trees are a hazard in urban areas. In Wellington, bark damage has been observed on trees next to roads and walkways, in parks frequented by people, and near to powerlines and houses. Damaged trees must be monitored, and hazardous branches or whole trees removed if they are a risk. Tree monitoring, pruning and removal is time-consuming and costly.

Many damaged trees provide value as amenity plantings on public and private property. Some trees damaged by kākā are over 50 to 100 years old and some are listed on the New Zealand Tree Register (New Zealand Notable Trees Trust 
2012). In particular, considerable damage has occurred on trees in the Wellington Botanic Garden. This garden contains many nationally and globally rare tree species and cultivars as well as trees of historical and cultural importance (Shepherd \& Cook 1988; Hill 2003). The Wellington Botanic Garden is recognised as a Historical Area by the New Zealand Historic Places Trust and as a heritage area under the Wellington City Council District Plan (Hill 2003). Many of the trees that have sustained damage from kākā sap foraging have irreplaceable historical value. For example, the Wellington Botanic Garden contains some of the earliest plantings of exotic conifers in New Zealand some of which have high levels of damage from kākā. These trees were crucial to the development of New Zealand's forestry industry, as tree species were trialled and seed for plantations was later sourced from these trees (Shepherd \& Cook 1988).

Damage on private property is also cause for concern. Safety risks are increased when residents are unaware of the presence of damage or the hazards posed by compromised tree structure. Costs of tree or branch removal can be significant and property damage may also impose high economic cost on residents.

\subsection{This study}

\subsubsection{Study area}

This study occurred in Wellington City, situated on the south-western coastal peninsular of the North Island, New Zealand $\left(41.28^{\circ} \mathrm{S}, 174.77^{\circ} \mathrm{E}\right)$. Wellington City is compact, covering an area of $290 \mathrm{~km}^{2}$. The central urban area is situated on the flat land surrounding the harbour, with residential areas and green belt on the surrounding hills.

An estimated 202,000 people reside in Wellington City (Wellington City Council 2013). The majority (77\%) of Wellingtonians are of European descent and smaller proportions are of Asian (13\%), Maori (7\%) or Pacific Island (5\%) ethnicity. 
Residents are relatively wealthy; $35 \%$ of residents earn over $\$ 50,000$ per annum, and are highly educated; $33 \%$ of residents hold a bachelor or higher degree. Females make up $52 \%$ of the population. Compared to the rest of New Zealand, there is a high proportion of people in the $25-34(18 \%)$ and $35-49(24 \%)$ age groups (Wellington City Council 2013).

Wellington has a mild temperate climate. Average monthly temperatures range from $17^{\circ} \mathrm{C}$ in February to $9^{\circ} \mathrm{C}$ in July (Wellington City Council 2012a). On average, there are 2065 hours of sunshine annually and $1249 \mathrm{~mm}$ of rain. Wind is a strong feature of the climate with an average of 22 days of gale force wind per year (days with a mean speed above 63km/hour, NIWA 2012).

Wellington City comprises considerable areas of greenspace, including remnant, regenerating and planted forest, parks, reserves and sports fields (Wellington City Council 2012c). There are approximately 3,600 hectares of Council-owned greenspace in Wellington City compared to 4,300 hectares of built urban environment, making Wellington one of New Zealand's greenest cities (Wellington City Council 2012c). Wellington City Council manages a number of substantially-sized greenspaces in the city, including the Wellington Botanic Garden, the Town Belt, Outer Green Belt and Otari/Wilton Bush- a reserve of remnant old-growth native forest (Wellington City Council 1998). ZealandiaKarori Wildlife Sanctuary $\left(41.290^{\circ} \mathrm{S} 174.753^{\circ} \mathrm{E}\right)$ is a 252 ha ecological restoration site situated less than $2 \mathrm{~km}$ from the centre of Wellington City. The sanctuary is surrounded by a mammal predator exclusion fence and all species of introduced mammals except house mice (Mus musculus) have been eradicated from the sanctuary.

\subsubsection{Study population}

North Island kākā were reintroduced to Wellington City, after being locally extinct for approximately 100 years, with the initial release of six captive-reared kākā to KWS in August 2002 (Miskelly et al. 2005). Subsequent translocations, immigration from nearby populations, and considerable local breeding success 
have led to a current estimated population in the Wellington area of approximately 180-250 birds (Karori Sanctuary Trust, unpubl. data).

Within KWS, kākā are provided with nest-boxes and year-round supplementary food, comprising sugar-water and commercially-prepared parrot pellets and nectivore mix (Raewyn Empson, Karori Sanctuary Trust, pers. comm.). The kākā population is closely monitored, particularly during breeding, and chicks from artificial nest boxes are fitted with individually-identifying coloured leg bands and microchipped before fledging. Until recently, unbanded adult kākā were also captured and tagged. A high proportion of the population is banded allowing individual identification and the collection of breeding, parentage and movement data. Although there is considerable information about the population within KWS, little is known about their movements, distribution or behaviour outside the sanctuary's fence.

Public reports indicate that kākā are commonly heard and sighted in the suburbs surrounding the sanctuary and sightings have been reported as far afield as Makara $\left(41.268^{\circ} \mathrm{S} 174.705^{\circ} \mathrm{E}\right)$, Tawa $\left(41.177^{\circ} \mathrm{S}, 174.820^{\circ} \mathrm{E}\right)$ and Red Rocks $\left(41.346^{\circ} \mathrm{S}, 174.689^{\circ} \mathrm{E}\right)$ on Wellington's south coast.

The KWS population has had considerable breeding success, with 78 and 60 kākā chicks fledged from artificial nestboxes in the 2010-11 and 2011-12 seasons, respectively (Karori Sanctuary Trust 2011, 2012a). At KWS clutches of up to six eggs and broods of three to five chicks are common (Karori Sanctuary Trust, unpubl. data)- much higher rates than the four eggs and two chicks reported elsewhere (Moorhouse 1991). Some females in the Wellington kākā population breed every year and some breed twice in one season. The high breeding success has resulted in a demographically-skewed population with a much larger proportion of juvenile birds than adults.

\subsubsection{Study objectives and thesis structure}

For this study, I investigated the emerging human-wildlife conflict caused by kākā in Wellington City, with a particular focus on sap feeding. If the kākā population 
in Wellington continues to grow, damage to trees and property is also likely to increase.

Human-wildlife conflicts are often well-established and intractable before research and management is implemented (Fall \& Jackson 2002). This study seized an opportunity to investigate a human-wildlife conflict as it emerged. This will enable the social and ecological drivers of conflict to be identified and addressed early and increase the potential for successful conflict mitigation.

This thesis begins with a short article based on preliminary research describing the tree damage caused by kākā in Wellington City. In Chapters Three and Four, I consider the ecological and behavioural characters of sap feeding. In Chapter Three, I investigate characteristics of trees and sites with bark damage to determine what influences tree selection by sap foraging kākā. In the fourth chapter, I describe sap feeding behaviour and identify the demographic characters of birds observed foraging for sap. In Chapter Five, I consider the human dimension of conflict with birds in Wellington City. A household questionnaire was used to investigate attitudes towards birds and bird-related problems and to determine factors that influence residents' attitudes. I investigate how experiencing problems caused by birds may influence attitudes, especially how conflict may change or moderate existing relationships between residents' attitude and their knowledge and engagement. In Chapter Six, I review the global literature on urban bird conflict to determine what characteristics of species increase the likelihood of a native bird species generating conflict in an urban landscape. A quantitative and comparative analysis of species and cogenera that do and do not cause conflict in urban landscapes is conducted. The final chapter summarises and discusses the overall findings of this study and provides recommendations and avenues for further study.

The chapters of this thesis are written as separate manuscripts for publication and so some repetition occurs between the chapters, especially in descriptions of the study site and problem. 



\section{Chapter Two: Tree damage in Wellington as a result of foraging for sap and bark- dwelling invertebrates by the North Island kākā (Nestor meridionalis septentrionalis)}

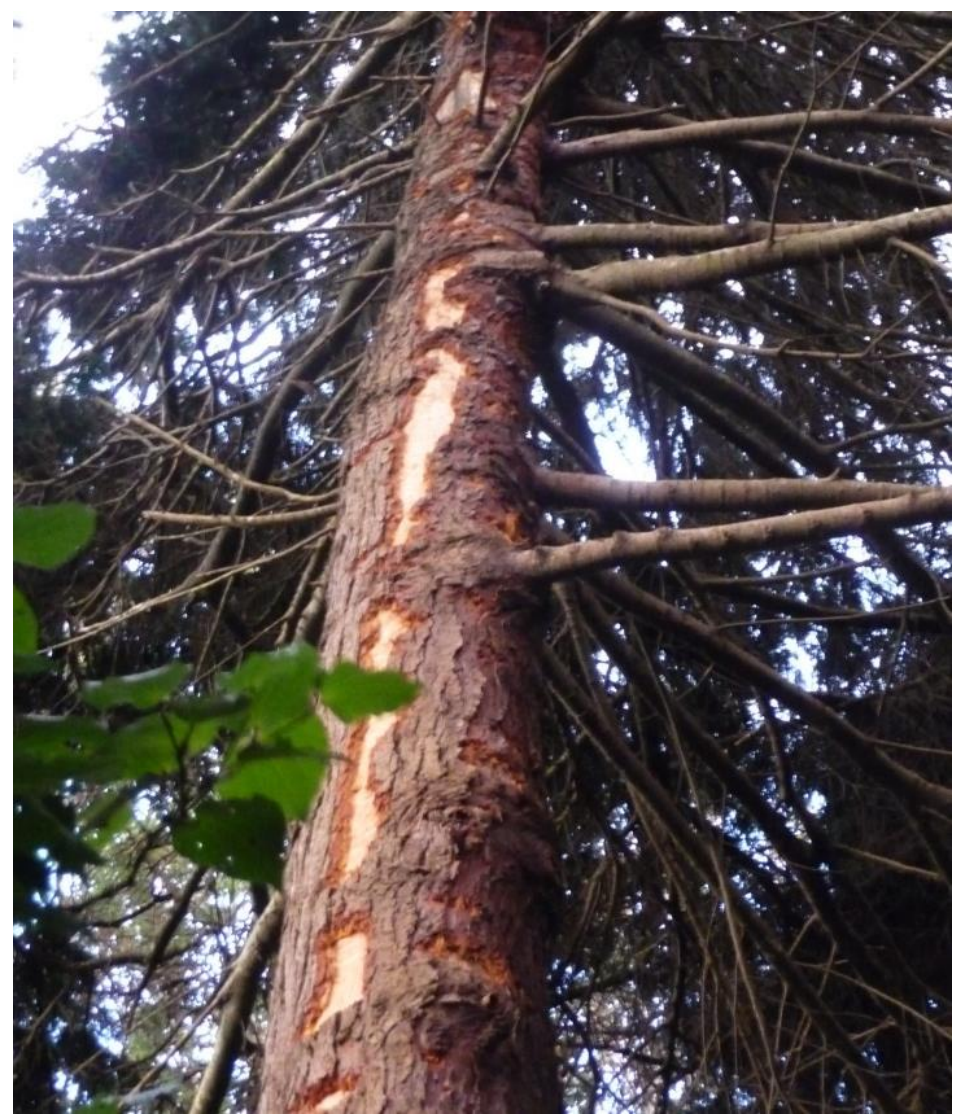

A Lawson cypress (Chamaecyparis lawsoniana) with removed patches of bark caused by sap foraging by kākā. Northland, Wellington.

Published as: Charles, K. E. 2012. Tree damage in Wellington as a result of foraging for sap and bark-dwelling invertebrates by the North Island kākā (Nestor meridionalis septentrionalis). Notornis 59:180-184.

This chapter has been reformatted for thesis consistency but has not been updated since publication. 
Kākā (Nestor meridionalis) forage for sap and invertebrates by removing bark and digging into the wood of live and dead trees. Damage to live trees as a result of sap feeding has been observed in native and plantation forests around the country, including in Westland (O'Donnell \& Dilks 1989), Nelson (Innes 1994), Pureora (Innes 1994), Whirinaki (Beaven 1996), and on Stewart and Little Barrier Is (O'Donnell 1993). Two techniques of sap feeding have been described: stripping bark to expose the surface cambium, and the prising open of horizontal 'trapdoors' (O'Donnell \& Dilks 1989). Kākā also feed on a variety of bark or wooddwelling invertebrates, particularly kanuka longhorn beetles (Ochrocydus huttoni) in mountain beech (Nothofagus solandri var. cliffortioides, Beggs \& Wilson 1987) and Hall's Totara (Podocarpus hallii, O’Donnell \& Dilks 1994). Although sap and bark-dwelling invertebrate foraging is known anecdotally, there is little literature describing the behaviour or resulting tree damage. Damage has not been previously described in urban areas, and apart from a study of sap feeding damage in plantation forests (Beaven 1996), research has been restricted to native forests. In this study, I detail the damage done to trees in urban areas of Wellington City from a reintroduced population of kākā. 


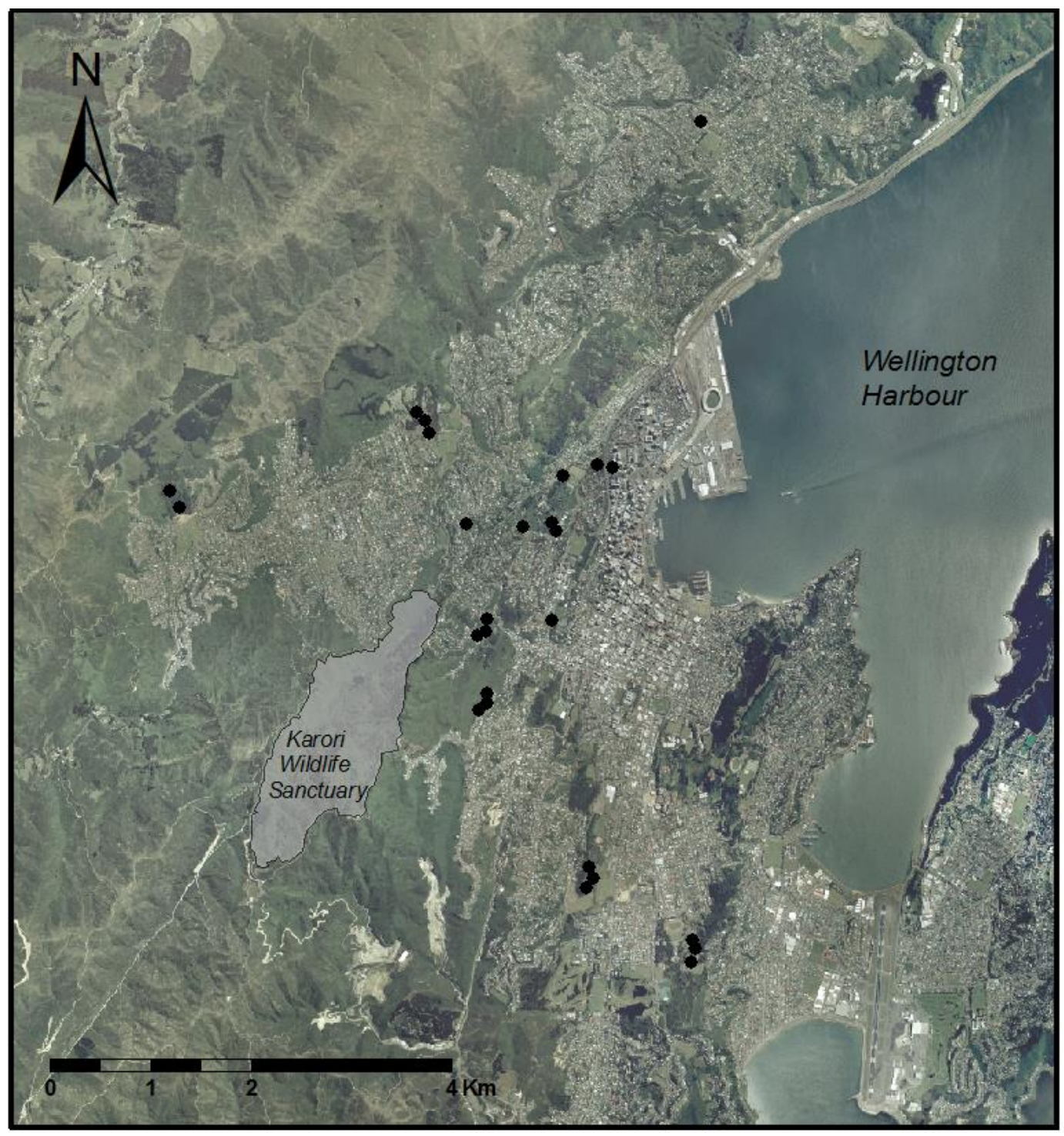

Figure 2.1 Currently known distribution of tree damage caused by North Island kākā (Nestor meridionalis septentrionalis) in Wellington, New Zealand. 
North Island kākā (N. m. septentrionalis) were reintroduced to the Wellington region with the release of six captive-reared kākā to Karori Wildlife Sanctuary ($41.290^{\circ} \mathrm{S}, 174.753^{\circ} \mathrm{N}$ ) in Aug 2002 (Miskelly et al. 2005). Subsequent translocations and local breeding have led to a current population in the area of 200 birds (Karori Sanctuary Trust, unpubl. data). Kākā are provided with supplementary food and nest boxes within the sanctuary's predator-proof fence but range widely outside the sanctuary. They are a commonly sighted in the suburbs surrounding the sanctuary and have been seen as far afield as Makara $\left(41.268^{\circ} \mathrm{S} 174.705^{\circ} \mathrm{E}\right)$, Tawa $\left(41.177^{\circ} \mathrm{S} 174.820^{\circ} \mathrm{E}\right)$ and Red Rocks $\left(41.346^{\circ} \mathrm{S}\right.$, $\left.174.689^{\circ} \mathrm{E}\right)$. The establishment and growth of the kākā population in Wellington is a wildlife restoration success.

From mid-2010 to mid-2012 I have been collating reports of bark damage from the public and Wellington City Council and Wellington Botanic Garden employees. All reports of damage were followed up and personally observed by myself to confirm that damage can be attributed to kākā. Additional tree damage has also been identified by opportunistic personal observation during other fieldwork. Bark damage was observed on trees in the Wellington Botanic Garden, Wellington City Council parks, road reserves and verges and on private land in many suburbs throughout the city

Two types of tree damage have been observed. The first consists of transverse gouges spaced at regular intervals along the trunk and main branches (Figure 2.2). These often expose the vascular cambium and dried sap can be present. Gouges can be up to $40 \mathrm{~cm}$ long but rarely extend beyond $2 / 3$ of the circumference of the trunk or branch. Similar to observations by O'Donnell and Dilks (1989) on southern rata (Metrosideros umbellata), trees with signs of sap feeding often have hundreds of scars. Trees near to those with extensive damage have been observed with 1-5 scars, suggesting that kākā may test a number of trees before selecting a preferred tree for foraging. This type of damage was observed on only a small number of species in Wellington, predominantly 
Eucalyptus spp. This technique of sap feeding appears to be distinct from the 'trapdoors' described by O'Donnell and Dilks (1989) as cambium is exposed in a continuous horizontal scar and bark is removed rather than levered downward.

The other type of damage is characterised by strips of bark being peeled off the trunk and/or branches of a tree (Figure 2.3). This results in patches of exposed vascular cambium that vary in size from a few centimetres to up to $2 \mathrm{~m}$ long. Some trees may only have one patch of removed bark whereas others have many areas of damage on the trunk and/or lateral branches. This type of damage has been observed on a wide variety of species, particularly conifers.

Damage has been observed on $>32$ taxonomically diverse tree species in Wellington city (Table 2.1). In some cases, damage is selective and localised, with damage located on one or a few clustered trees with surrounding trees undamaged. In other areas, such as the Wellington Botanic Garden, large groves of trees have been damaged. This represents the first known observation of kākā damage on many of these species and on such a large number of tree species in one area. It has been suggested that sap feeding behaviour is not common and is likely to be restricted to a few plant species (O'Donnell 1993). Observations in Wellington city indicate that kākā may be able to utilise sap from a wider variety of tree species than previously thought. 


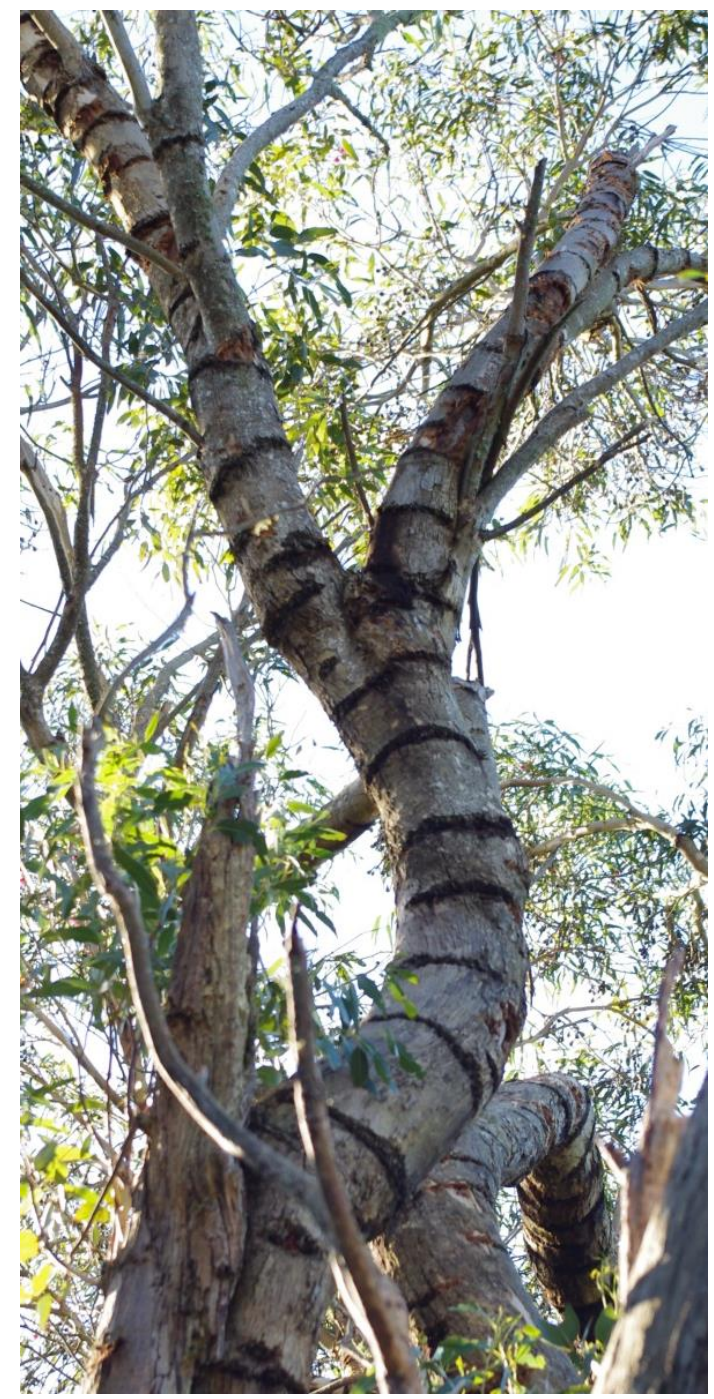

Figure 2.2. Damage to Eucalyptus sp. in Wellington, New Zealand as a result of sap feeding by North Island kākā. Horizontal gouges through the bark layer are characteristic of damage to this tree genus

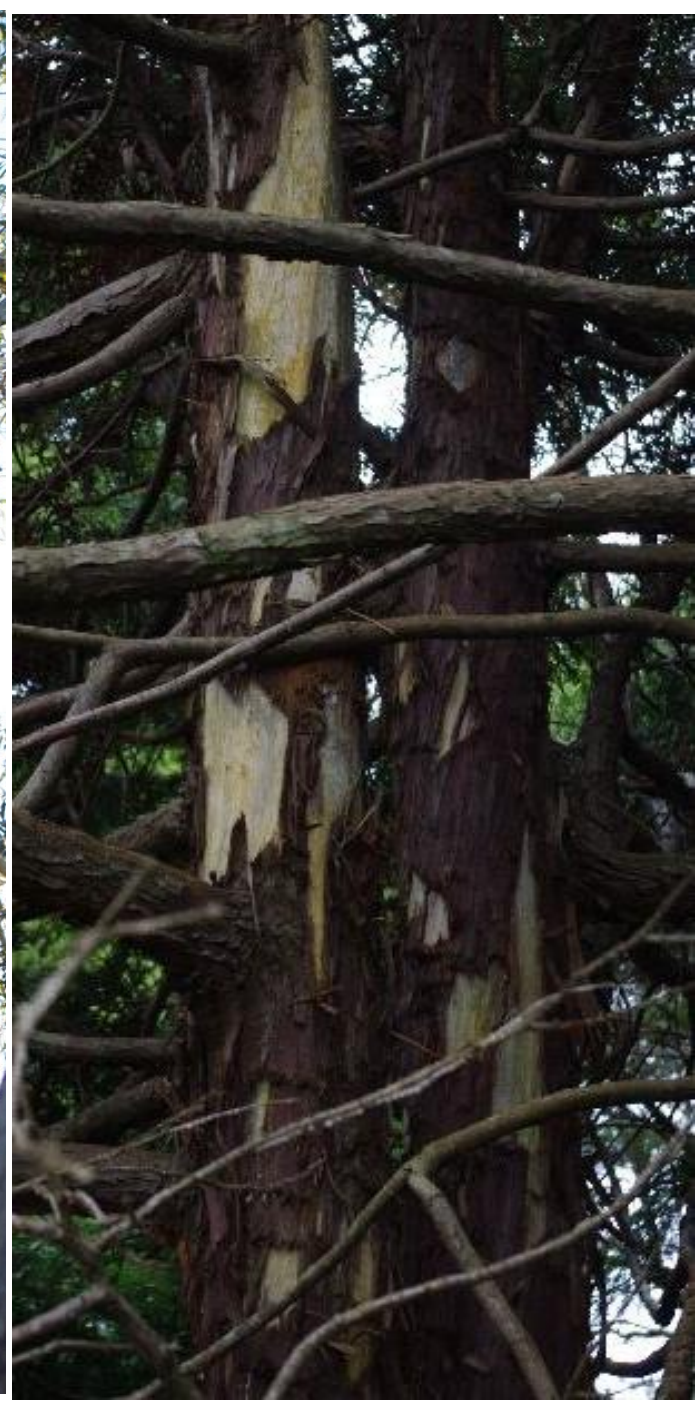

Figure 2.3 Damage to Thujopsis dolabrata in Wellington, New Zealand as a result of sap feeding by North Island kākā. This type of damage is present on many tree species, particularly conifers. 
Table 2.1 Tree species observed to have bark damage caused by North Island Kākā (Nestor meridionalis septentrionalis) in Wellington, New Zealand.

Unless otherwise indicated all damage has been observed directly by the author.

\begin{tabular}{|c|c|c|}
\hline Species & Common Name & Location \\
\hline Chamaecyparis lawsoniana & Lawson cyprus & WBG $^{1}$, Brooklyn \\
\hline Thujopsis dolabrata & Japanese cyprus & WBG \\
\hline Taxodium distichum & Bald cyprus & WBG \\
\hline Sequoia sempervirens & California redwood & WBG \\
\hline Sequoiadendron giganteum & Giant sequoia & WBG \\
\hline Metasequoia glyptostroboides & Dawn redwood & $W_{B G}{ }^{2}$ \\
\hline Cupressus macrocarpa & Macrocarpa & WBG, Newtown \\
\hline Pseudotsuga menziesii & Douglas fir & WBG \\
\hline Pinus radiata & Radiata pine & WBG \\
\hline Pinus nigra & European black pine & WBG \\
\hline Pinus pinaster & Maritime pine & WBG \\
\hline Betula pendula & Silver birch & WBG \\
\hline Thuja plicata & Western red cedar & $W_{B G}{ }^{2}$ \\
\hline Cedrus atlantica & Atlas cedar & $W_{B G}{ }^{2}$ \\
\hline Cedrus deodara & Himalayan cedar & $W_{B G}{ }^{2}$ \\
\hline Cryptomeria japonica & Japanese cedar & Newtown \\
\hline Juniperus chinensis & Chinese juniper & WBG \\
\hline Eucalyptus pulchella & White peppermint & $W_{B G}{ }^{2}$ \\
\hline Eucalyptus gunnii & Cider gum & Newtown \\
\hline Eucalyptus Spp. (unidentified) & Eucalyptus & Aro Valley, Newtown \\
\hline Acacia Sp. (unidentified) & Acacia & Brooklyn \\
\hline Quercus robur & English oak & $W_{B G}{ }^{2}$ \\
\hline Chiranthodendron pentadactylon & Devil's hand tree & WBG \\
\hline Liriodendron tulipifera & Tulip tree & $W_{B G}{ }^{2}$ \\
\hline Prunus serrulata & Flowering cherry & Northland, Aro Valley \\
\hline Prumnopitys ferruginea & Miro & $W B G^{2}$ \\
\hline Vitex lucens & Puriri & $W_{B G}{ }^{2}$ \\
\hline Sophora microphylla & Kowhai & WBG \\
\hline Kunzea ericoides & Kanuka & WBG \\
\hline Melicytus ramiflorus & Mahoe & Karori Wildlife Sanctuary \\
\hline Lophomyrtus bullata & Ramarama & Karori Wildlife Sanctuary \\
\hline Pseudopanax arboreus & Five finger & Khandallah \\
\hline
\end{tabular}

${ }^{1}$ Wellington Botanic Garden. ${ }^{2}$ Observed by James Jones, Wellington Botanic Garden 
Tree damage in Wellington has been observed predominantly on conifers and Eucalyptus species. Previous observations of kākā sap feeding in native forest habitats have also predominantly been on Myrtaceae species; rata (O'Donnell \& Dilks 1989), hybrid rata/pohutukawa (O’Donnell 1993), and kanuka (Kunzea ericoides, Chris Smuts-Kennedy, pers. comm.), or conifers; rimu (Dacrydium cupressinum, O’Donnell 1993), matai (Prumnopitys taxifolia, Beaven 1996), tawa (Beilschmiedia tawa) and totara (Podocarpus totara, O’Donnell 1993; Beaven 1996). Why these taxa are favoured is unknown. Perhaps it is due to the sugar concentration or volume of sap, or bark characteristics affecting sap accessibility. Removing bark to feed on sap is rare among vertebrates, yet among other sap feeders similar tree species are targeted. Marsupial gliders in Australia specialise in feeding on Eucalyptus sap (Craig 1985), and Hawaiian honeycreepers (Hemignathus munroi) forage for sap exclusively on Metrosideros polymorpha (Pejchar \& Jeffrey 2004).

Native tree species in Wellington city, particularly within the Karori Wildlife Sanctuary, have also sustained damage. Sap feeding scars have been identified on mahoe (Melicytus ramiflorus), ramarama (Lophomyrtus bullata) and kanuka and two female kākā were observed removing bark and licking exudate from the exposed sapwood of mahoe (pers. obs.). Scars resulting from extraction of Pururi moth (Aenetus virescens) larvae from mahoe trunks have also been observed within Karori Wildlife Sanctuary (pers. obs.). Bark damage has not been observed in Wellington on totara, rimu, rata or pohutukawa (Metrosideros excelsa), despite their presence near to damaged trees.

The tree damage caused by kākā in Wellington is a concern for a number of reasons. Damage compromises the structural integrity of the tree, leaving it vulnerable to branch fall especially during high winds (James Jones, pers. comm.). Epicormic growth has been observed on damaged Eucalyptus spp.. This is characterised by rapid shoot elongation with little secondary growth, resulting in 
numerous weak stems. Due to their location in urban streets, parks and backyards these trees are a significant hazard.

Bark damage may cause crown dieback (Innes 1994) and this has occurred on a number of trees in Wellington. Dieback and epicormic growth indicate physiological stress which may increase a tree's vulnerability to infection (Schoeneweiss 1975) and bark removal may increase susceptibility to pathogens (Beaven 1996). Damaged trees must be monitored, and hazardous branches or whole trees removed if they are assessed as a risk.

Damage appears to be mainly present in large mature trees. In the Botanic Garden many of the trees targeted have historical value as they represent some of the earliest plantings of exotic trees, particularly conifers, in New Zealand. Damaged trees include those listed as notable trees.

In addition to removing the bark of trees, there is some evidence that kākā cause other vegetation and property damage in Wellington City. This includes anecdotal reports from residents that kākā are eating crops of fruit or nuts and causing minor damage to joinery, cladding and chimneys. Similar problems caused by sulphur-crested cockatoo (Cacatua galerita) in Australia provide an example of the potential for parrots to generate human-wildlife conflict in urban areas. When attracted by food provision, these birds damage garden furniture, window and door frames and solar water heating systems (Temby 2004).

Damage on private property, although unlikely to have significant impact on livelihoods, is still cause for concern. Residents may be unaware of the safety risks posed by limbs weakened by bark removal. Property damage from kākā may also change people's attitudes and behaviour toward kākā and perhaps lessen their support for conservation. Ensuring public support is vital for private conservation organisations, such as the Karori Sanctuary Trust, that rely on donations from the public. Overseas research has found that experiencing property damage by wildlife may reduce people's support for conservation (Gadd 2005). 
A detailed study of sap feeding may be important to the long term conservation of kākā (O'Donnell \& Dilks 1989) and the Wellington population is ideal for studying this behaviour. The population is almost entirely banded and breeding is closely monitored, enabling individual identification and the collection of age, sex and group relationship data. The presence of kākā in an urban area also provides increased opportunities to directly observe the behaviour of kākā while engaged in sap and invertebrate foraging.

It has been suggested that sap may be an important supplementary food during late winter and early spring when there is a shortage of high energy food available (O’Donnell \& Dilks 1989). Supplementary food (sugar water, parrot pellets, and a commercially prepared nectivore food) is provided within Karori Sanctuary year round, and the availability of easily accessible high quality food may reduce the need for sap feeding. The identity of kākā visiting feeders within the sanctuary is monitored monthly and provides an opportunity to investigate whether the same or different individuals also engage in sap foraging.

Given recent breeding success, it is likely that the kākā population in Wellington will continue to grow and therefore this problem is likely to increase. Further study of kākā behaviour that results in tree damage is warranted. Investigation into tree and site selection for sap and invertebrate foraging and the extent of damage in Wellington city will provide an understanding of the current situation and may enable predictions as to future changes. Research may enable practical recommendations for reducing damage and mitigating costs associated with monitoring and tree removal.

Research into social as well as ecological aspects of wildlife issues has been found to be vital in understanding and managing human wildlife conflicts overseas (Dickman 2010). Consideration of people's attitudes towards kākā and kākā damage will provide an understanding of the scope of this issue from a human perspective. With continued conservation success, avian-human conflict 
may increase in New Zealand and it is important to investigate how experience of conflict may impact on environmental attitudes, beliefs and behaviours. 



\section{Chapter Three: The characteristics of trees selected by kākā for sap foraging}

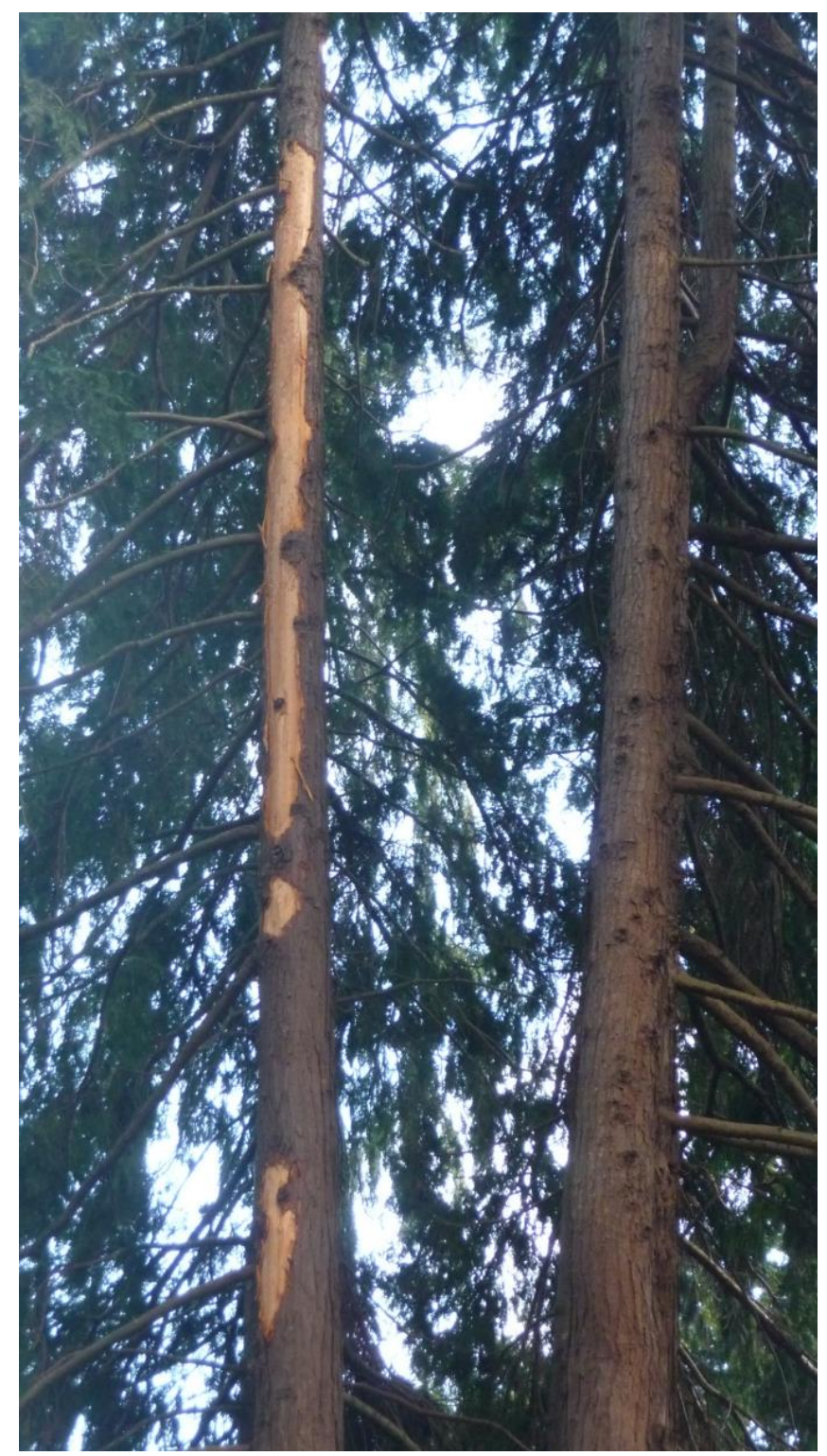

Two Lawson cypress (Chamaecyparis lawsoniana) trees in Wellington Botanic Garden. One has been extensively damaged by kākā, the other has no damage. 


\section{Abstract}

Kākā (Nestor meridionalis) forage for phloem sap by removing bark from trees. A range of exotic and native tree species have been damaged by kākā sap foraging in Wellington City and this has led to an emerging conflict with residents because of increased risks of branch and tree fall, loss of amenity values and financial costs of tree management. It is not known how kākā select trees for sap feeding. The aim of this study was to quantify what characteristics of trees and sites make trees prone to sap feeding. I sampled the characteristics, microhabitat and distribution of 282 trees, in 45 groups, at 15 sites across public parks and reserves in Wellington City. An Information-Theoretic approach to model selection and averaging was employed to determine the relative influence of variables on tree selection for sap feeding. Damage was observed on 85 trees of 10 different species. Exotic tree species, especially conifers such as macrocarpa (Cupressus macrocarpa) and Lawson cypress (Chamaecyparis lawsoniana), were significantly more likely to have been damaged than native species (Fisher's exact test, $p<0.001)$. A tree's diameter at breast height $(\mathrm{DBH})$ was the most influential predictor of tree selection $\left(\Sigma \omega_{i}=0.859\right)$ and mean DBH of damaged trees $(\bar{x} \pm S E, 64.8 \pm 5.2 \mathrm{~cm})$ was twice that of undamaged trees $(32.9 \pm 4.5 \mathrm{~cm})$. Topographic exposure was also an influential predictor of tree selection $\left(\sum \omega_{i}=\right.$ 0.739). Kākā select larger trees at more exposed sites for sap feeding. Monitoring to identify hazardous trees should be targeted towards large exotic conifers at exposed sites. Planting species, such as native conifers, that are favoured for sap feeding yet resilient to the effects of bark damage, may mitigate the problems associated with kākā tree damage. 


\subsection{Introduction}

\subsubsection{Sap feeding}

Stripping, removing or piercing bark in order to feed on sap and other plant exudates is a rare behaviour among vertebrates (Snyder 1992). The most wellknown and studied sap-feeders are the woodpeckers, such as the yellow-bellied sapsucker (Sphyrapicus varius, Tate 1973; Eberhardt 2000) and the white-fronted (Melanerpes cactorum, Blendinger 1999) and white-headed woodpecker (Picoides albolarvatus, Kozma 2010). The 'akiapōlā'au, a Hawaaian honeycreeper (Hemignathus munroi, Pejchar \& Jeffrey 2004), and the glossy flowerpiercer (Diglossa lafresnayii, Martin et al. 2009) are the only other birds described in the literature as causing bark wounds for sap feeding. Other vertebrate species that feed on sap are the marsupial yellow-bellied (Petaurus australis, Mackowski 1988; Goldingay 1991) and sugar gliders (Petaurus breviceps, Smith 1982), a few species of squirrel (Sciurus spp., Kenward 1982; Kenward et al. 1988; Heinrich 1992; Snyder 1992) and marmoset (Family: Callitrichidae, Coimbra-Filho \& Mittermeier 1976; Lacher et al. 1984). The kākā is the only parrot species known to produce bark wounds in order to feed on sap, although the crimson rosella (Platycercus elegans) has been observed maintaining sap flow at wounds created by the yellow-bellied glider (Chapman et al. 1999).

\subsubsection{Tree selection in sap feeding species}

A feature common to all sap-feeding vertebrates is how highly selective they are of individual trees for sap-feeding. Studies of preference (resource selection) usually compare the use of trees for sap feeding (i.e. presence of characteristic bark damage) with tree availability, due to the difficulties of discerning use from non-use. The factors involved in tree selection and the mechanisms used for tree choice have been studied in a few sap feeding species yet remain poorly understood and there is little consensus between studies (Snyder 1992). This may be due to the complexity and large number of influences on tree selection. For example, multiple mechanisms are likely to affect sap flow, content and 
availability (Goldingay 1987) and can differ across season, habitat and geographic locality (Blendinger 1999; Eyre \& Goldingay 2005).

Studies of tree selection by yellow-bellied gliders have found a range of factors may be important, with preferential feeding on larger trees (Eyre \& Goldingay 2005) with greater sap flow (Goldingay 1987) and thinner bark (Mackowski 1988). The 'akiapōlā'au was also found to preferentially select trees that are larger, with greater sap flow, and thinner bark but also those situated on an easterly aspect (Pejchar \& Jeffrey 2004). A study of yellow-bellied sapsucker, however, found no difference in bark thickness, bark moisture, crown size, soil moisture, tree density or distance from nest between used and unused trees (Eberhardt 2000). Tree size may impact on the quality or availability of sap as larger trees may have increased surface area for photosynthesis and increased hydrostatic pressure (Crafts \& Crisp 1971; Pejchar \& Jeffrey 2004).

Despite ambiguity about what characters of trees are selected, sap feeders can be highly selective of tree species and many preferentially feed on only one or a few species. Yellow-bellied gliders will forage from a maximum of three tree species at a site but most commonly from a single species (Eyre and Goldingay 2005). The 'akiapōlā'au feeds exclusively on sap from Metrosideros polymorpha (Pejchar \& Jeffrey 2004). In Brazilian gallery forests, the common marmoset (Callithrix jacchus penicillata) was found to feed on 14 tree species but $87 \%$ of damage occurred on just three of those (Lacher et al. 1984). Other sap feeding animals feed on a much wider suite of tree species, such as the yellow-bellied sapsucker which has been described feeding on up to 250 different species across its range (Ostry \& Nicholls 1976). The tree species selected may vary seasonally, as it does for white-bellied woodpecker (Blendinger 1999), and geographically, such as the different eucalyptus species fed on by yellow-bellied gliders in different locations (Goldingay 1991; Chapman et al. 1999).

Many sap feeding species, such as the 'akiapōlā'au, yellow-bellied glider and magellanic woodpecker, preferentially forage on larger trees (Pejchar \& Jeffrey 
2004; Eyre \& Goldingay 2005; Schlatter \& Vergara 2005). Sap production and accessibility may influence the quality and quantity of the sap resource provided by a tree and a number of sap feeding species select trees based on sap characteristics. Sap flow volume was higher and flow latency shorter in trees selected for feeding by the 'akiapōlā'au (Pejchar \& Jeffrey 2004). Trees in use for sap feeding by yellow-bellied gliders had a higher sap flow volume (Goldingay 1987). Sap feeders may also select trees based on higher sugar, protein or nutrient concentrations in sap (Snyder 1992). Conversely, trees may be selected based on lower levels of secondary defence compounds in the sap or bark (Goldingay 1991; Snyder 1992; Pejchar \& Jeffrey 2004).

Breaching the outer bark layer to access phloem tissue is likely to be the greatest barrier to sap feeding. Bark characteristics, therefore, may be important in determining sap accessibility and tree selection. The yellow-bellied glider (Mackowski 1988) and 'akiapōlā'au (Pejchar \& Jeffrey 2004) preferentially target trees with smooth and thin bark for sap feeding. Nevertheless, the importance of bark thickness to tree selection may also depend on a species' ability to remove or penetrate the bark. Bark thickness did not differ between used and unused trees for yellow-bellied sapsuckers (Eberhardt 2000). The ease at which yellowbellied sapsuckers can penetrate bark may mean that other factors become more important in tree selection.

A tree's microhabitat may influence its selection for sap foraging. Tree density, slope, aspect and altitude impact on microhabitat conditions such as local temperature, light and water availability, and competition for these resources (Pejchar \& Jeffrey 2004). These factors may directly impact on an animal during sap foraging or may indirectly influence tree selection by impacting on other characteristics such as the quality and quantity of sap. For example, trees at lower densities may receive more light and experience less competition which may lead to more concentrated or faster flowing sap. The trees on east-facing slopes favoured by the 'akiapōlā'au and the yellow-bellied glider (Pejchar \& 
Jeffrey 2004; Eyre \& Goldingay 2005) may receive greater sun exposure or higher levels of soil moisture (Bale et al. 1998; Pejchar \& Jeffrey 2004). For similar reasons, yellow-bellied glider sap feeding trees were located mid-slope (Craig 1985), and on convex topography for 'akiapōlā'au (Pejchar \& Jeffrey 2004).

\subsubsection{Kākā sap feeding}

Sap is an important seasonal food source for kākā (Nestor meridionalis: Nestoridae, Beggs \& Wilson 1987; O'Donnell \& Dilks 1989). Kākā strip patches or tear gouges through bark leaving characteristic bark wounds. They lick or scrape phloem sap that leaks from wounded edges and wells on the exposed cambial surface (Innes 1980; O'Donnell \& Dilks 1989; Charles 2012). They will also lick sap from bark pieces as they are removed from the tree (Beaven 1996).

Sap feeding occurs on a range of native and exotic tree species. Native species that are commonly used include southern rata (Metrosideros umbellata, O'Donnell \& Dilks 1989), rimu (Dacrydium cupressinum, O'Donnell \& Dilks 1989; O'Donnell 1993), matai (Prumnopitys taxifolia, Beaven 1996), tawa (Beilschmiedia tawa), mountain beech (Nothofagus solandri var. cliffortioides, Beggs 1988), mahoe (Melicytus ramiflorus, Berry 1998) and tōtara (Podocarpus totara, O'Donnell 1993; Beaven 1996). A range of exotic species, including Douglas fir (Pseudotsuga menziesii), macrocarpa (Cupressus macrocarpa), California redwood (Sequoia sempervirens), and many pine species, have also been described with characteristic sap feeding scars (Innes 1994; Beaven 1996; Berry 1998; Charles 2012).

The factors governing sap tree selection by kākā have received little study. In south Westland, $74 \%$ of sap feeding damage was found on southern rata despite this species comprising only $2.6 \%$ of canopy trees in the area (O'Donnell \& Dilks 1989). This study found that diameter at breast height (DBH) did not significantly influence tree selection, although there appeared to be a trend towards selection of larger trees. Early observations in Southland found scars on all sizes of rimu above $15 \mathrm{~cm}$ DBH (Holloway 1948). 
Beaven (1996) investigated tree selection by kākā in plantation forests but was not able to determine the factors important in the selection of individual trees. The presence or extent of damage was not found to be related to $\mathrm{DBH}$ or ground physiography. The amount of damage was found to be related to geographic location. More extensive damage occurred closer to native forest and did not occur further than $1 \mathrm{~km}$ from native forest. Beaven (1996) suggested that other factors such as a tree being higher than its neighbours may be important for selection.

\subsubsection{Kākā sap feeding in Wellington}

North Island kākā (N. m. septentrionalis) were reintroduced to Wellington City with the release of six captive-reared kākā to Zealandia-Karori Wildlife Sanctuary (hereafter KWS, $41.290^{\circ} \mathrm{S} 174.753^{\circ} \mathrm{E}$ ) in August 2002 (Miskelly et al. 2005). The population is currently estimated at $180-250$ birds (Karori Sanctuary Trust, unpubl. data).

In Wellington City, bark damage is widespread and found on trees in many public parks, reserves and forest fragments (hereafter greenspaces) and on private property. Kākā appear to be selective of trees for sap feeding (Charles 2012) and damaged trees are not spread evenly across the landscape. The extent and severity of damage varies between sites. In some cases, damage is localised, with sap feeding scars located on one or a few clustered trees with surrounding trees undamaged. In other areas large groves of trees have been damaged.

During preliminary research for this thesis, bark damage caused by kākā was observed on 32 tree species in Wellington (Charles 2012). Tree damage was predominantly seen on conifers and Eucalyptus species. Although exotic trees are more common in Wellington City, the few observations of sap feeding scars on native species suggests that kākā may preferentially feed on exotic tree species.

The tree damage caused by kākā in Wellington is a concern for a number of reasons. Damage compromises the structural integrity of trees (James Jones, 
Wellington Botanic Garden, pers. comm.), induces epicormic growth, causes foliage dieback (Innes 1994), and may increase trees' susceptibility to pathogens (Beaven 1996). Damaged trees are prone to branch failure and in extreme cases may be killed by sap foraging. Due to their location on private property and in urban streets and parks damaged trees are a significant hazard, posing risks to buildings, vehicles, power transmission lines and pedestrians. Damaged trees must be monitored and branches or whole trees removed if they pose a risk. Tree removal is costly and reduces the aesthetic and amenity values of trees.

Considerable damage has occurred to trees at the Wellington Botanic Garden (Charles 2012). In part due to its botanical collections, the Wellington Botanic Garden is recognised as a Historical Area by the New Zealand Historic Places Trust and as a heritage area under the Wellington City Council District Plan (Hill 2003). This living plant collection contains many rare tree species and cultivars, species not planted elsewhere in New Zealand and trees of historical and cultural importance (Shepherd \& Cook 1988; Hill 2003). Some trees that have been damaged by kākā at the Wellington Botanic Garden have irreplaceable historical value as they are some of the earliest plantings of exotic trees, particularly conifers, in New Zealand.

\subsubsection{Aims}

My aim was to investigate tree selection for sap foraging by kākā by determining the variables that influence the distribution of kākā-caused bark damage in Wellington City. It is clear that kākā sap feed more on some tree species than others. My interest was to understand the characters of trees that are selected for sap feeding. Characteristics that may influence tree selection for sap feeding identified from preliminary observation of kākā damage and literature on other sap feeding species were measured at the tree and site level. These measurements were compared for damaged and undamaged trees to determine their influence on tree and site selection to provide a greater understanding of kākā sap feeding ecology, particularly in an urban landscape. 
By understanding the factors that influence the distribution of sap feeding, and hence tree damage, it is hoped that recommendations can be made to limit the extent or severity of the problem in Wellington City. Understanding tree selection is the first step in devising ways to reduce the impact of sap feeding damage, including recommending tree species for future tree planting. Models that explain the distribution of damage may be used to predict areas or trees at greatest risk of kākā damage to aid in damage monitoring and mitigation.

\subsection{Method}

\subsubsection{Kākā distribution and damage mapping}

Visual and auditory observations ("sightings") of kākā and observations of kākā caused tree damage were collated and mapped. A request for sightings and reports of damage was published in a local newspaper (The Dominion Post, 6 March 2012) and on relevant websites and distributed via email lists and social media. These kākā sighting reports were combined with public submissions to the 'report-a-bird' form on the KWS website (Karori Sanctuary Trust 2012b) from 2010 and 2011 to produce a map of the spatial extent of kākā in Wellington City (

Figure 3.1). Since kākā were introduced relatively recently and the population is growing, any sites where kākā have been observed since reintroduction were included as part of the current distribution. The most extreme $5 \%$ of sightings points, defined as those furthest from the midpoint of sightings, were removed and a polygon of kākā extent was constructed around remaining sightings points following the periphery of the city.

In addition to the above methods, personal communications with landowners, private aborists, staff from KWS, Wellington Botanic Garden and Wellington City Council Parks \& Gardens, and personal observations during preliminary fieldwork were used to collate observations of trees damaged by kākā. I personally viewed 
all reported trees to confirm that damage fitted the characteristics of kākā sapfeeding damage. The distribution of trees damaged by kākā was mapped also (

Figure 3.2).

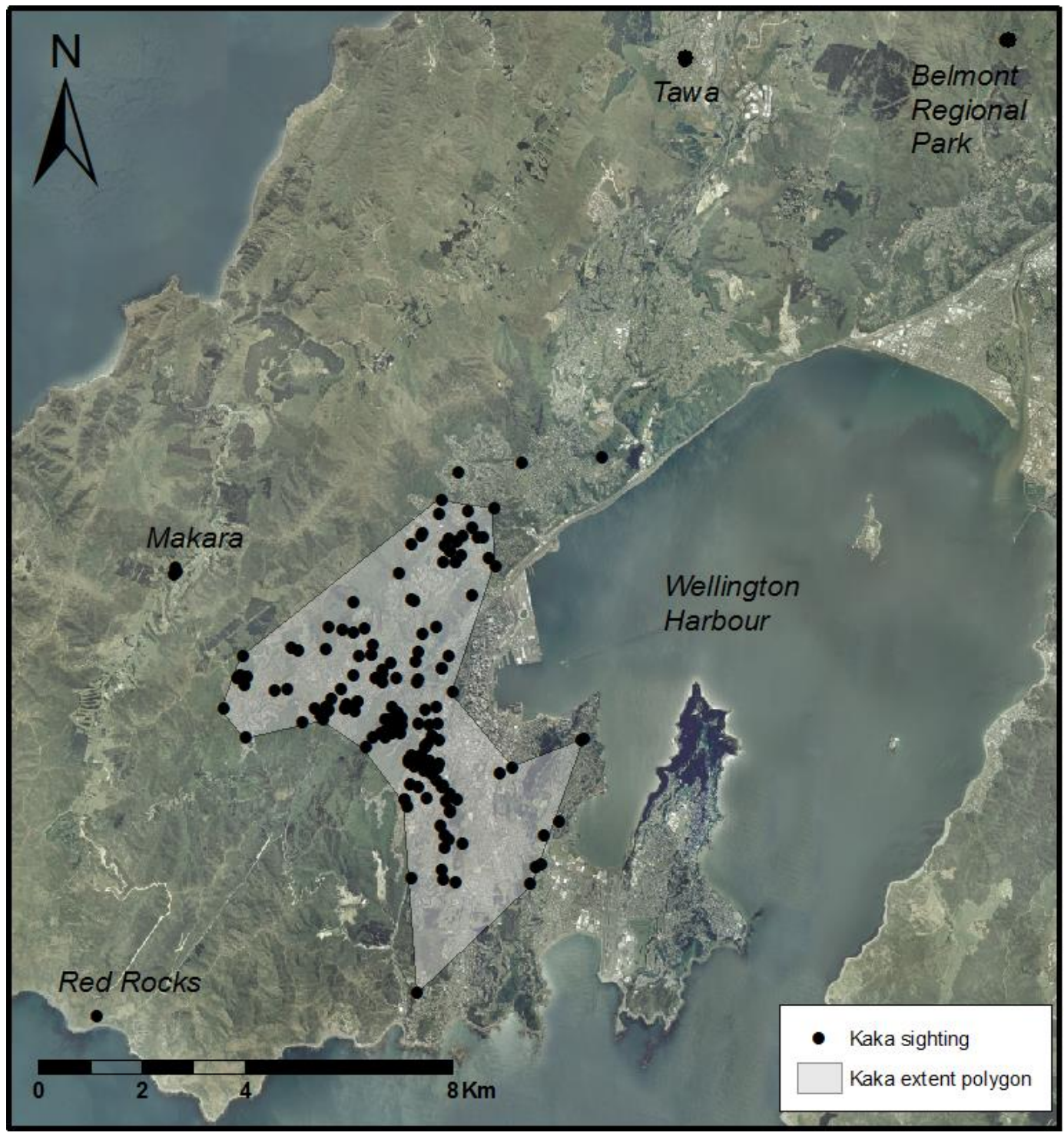

Figure 3.1 Spatial extent of kākā in the Wellington City, developed from sightings collated from public submissions in 2010 and 2011 to the 'report-a-bird' form on the Zealandia-Karori Wildlife Sanctuary website and responses to a request for sightings published in The Dominion Post (6 March 2012) and on relevant websites and distributed via email lists and social media. 


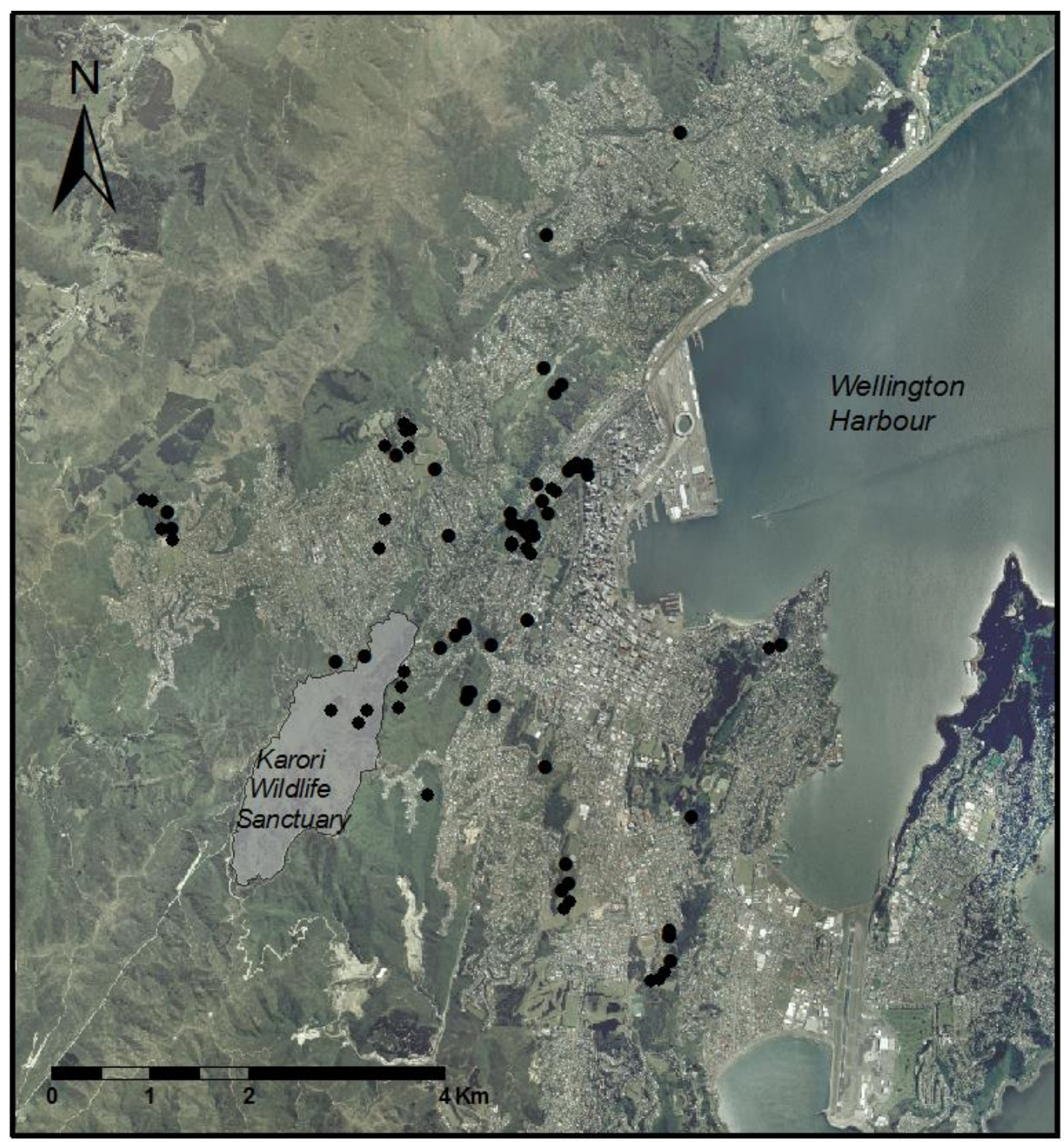

Figure 3.2 The distribution of tree damage in Wellington City identified through personal observation and reports of damage supplied by the public in response to a request published in The Dominion Post (6 March 2012) and on relevant websites, and distributed via email lists and social media. Black dots indicate the location of a damaged tree or trees. 


\subsubsection{Sampling method}

A stratified random sample of public greenspaces in Wellington City was selected for sampling from within the kākā extent polygon (

Figure 3.1). All greenspaces with known damage were selected $(n=5)$, and the remaining 10 sites were randomly selected. All sites were publically accessible Wellington City Council owned or managed areas.

A starting location for sampling within a site was randomly selected on a map of the site prior to my arrival and searching took place from this point until a damaged focal tree was found. This focal tree and the nine closest trees with overlapping canopies were defined as a group for the purposes of sampling. A tree group was defined in this way to be both tree-centric; as nearby trees exert competitive pressures on each other, and kākā-centric; as kākā will often climb and walk between trees along adjacent branches rather than flying. If fewer than nine trees formed a continuous canopy with the focal tree, all trees in the group were sampled. As kākā select mature trees for sap feeding, all trees sampled had a minimum DBH of $5 \mathrm{~cm}$ to exclude herbaceous plants and tree saplings. Tree species were not sampled in accordance with availability due to the relative rarity of sap feeding damage.

The focal tree and each of the nine neighbours were sampled for a suite of 12 variables: seven describing individual tree characteristics and five describing their microhabitat and distribution on the landscape. These variables were generated from previous research of sap foraging in kākā and other species, and preliminary observations in Wellington (Charles 2012).

Tree height; calculated using a hand held clinometer, species and diameter at breast height ( $\mathrm{DBH}$, measured at $1.3 \mathrm{~m}$ ) were recorded. A $50 \mathrm{~mm}$ diameter circular section of the outer bark layer (the rhytidome) was removed from a randomly selected point at breast height on the trunk of each tree using a hole saw to drill through the outer bark layer to expose living phloem tissue. Bark thickness was calculated as the mean of the bark thickness at three randomly 
selected points on the edge of each circle of bark removal. Bark type was categorised as smooth or ridged. Decorticating bark was included in the smooth bark category as the bark surface was smooth below shed bark.

Cambial electrical resistance and solute concentration of phloem tissue were assayed to provide a relative estimate of the energy available from sap feeding. Solute concentration of phloem tissue was measured in a similar way to that used by Martinez-Trinidad (2010). A piece of tissue $25 \times 10 \times 2 \mathrm{~mm}$ was excised from where the phloem had been exposed due to bark removal and placed in a vial with $1 \mathrm{ml}$ distilled water. After 48 hours, $0.3 \mathrm{ml}$ of water was tested using a hand-held refractometer (Atago Pocket PAL-06S) and salinity values were converted to Degrees Brix $\left(1^{\circ} \mathrm{Bx}=1\right.$ gram dissolved solid in 100 grams of solution). As sap is composed mainly of sugars (Stewart et al. 1973; Snyder 1992), this provides a measurement of relative carbohydrate concentration (Goldingay 1987).

Cambial electrical resistance was assayed in a manner similar to that used by Eberhardt (2000). Stainless steel electrodes of a DSE Q5300 digital multimeter were inserted vertically $20 \mathrm{~mm}$ apart into the exposed phloem layer to a depth of approximately $5 \mathrm{~mm}$. The minimum electrical resistance from 5 minutes of a pulsed electrical current was recorded at two points and averaged to provide a mean value of cambial electrical resistance (CER). CER measures the resistance to movement of an electrical current through the cambial tissue, which has been found to correlate with growth rate, phloem width (Carter \& Blanchard 1978) and live bark thickness (Kile et al. 1982). High vigour, wider phloem and thicker live bark all indicate a greater turnover of sap sugars and higher sugar availability to feeders (Mackowski 1988). Studies of yellow-bellied glider sap feeding have suggested that this species selects trees with lower CER (Mackowski 1988; Eberhardt 2000). Microhabitat variables; aspect and TOPEX (topographic exposure) were measured at each site, and surrounding tree density was measured for each tree. 
Aspect was a binary variable describing a site as north or south facing. TOPEX values were calculated as the sum of the inclination to the horizon at each of the eight cardinal points. Tree density was measured as the number of live trunks $\geq 5$ $\mathrm{cm}$ DBH within a $10 \mathrm{~m}$ radius of each sampled tree.

For each tree group, the shortest distance to the KWS fence, where kākā were released and supplementary food is available, was calculated using Google Earth (Version 5.1.3533.1731, Google Inc. 2009). Human disturbance was measured as the minimum distance from each tree group to a building or road also using Google Earth.

Trees were inspected using binoculars to identify bark damage caused by kākā. Sap feeding damage was identified as removed patches or transverse gouges in bark of the trunk or branches such that the outer and inner bark layers were removed to expose the vascular cambium underneath, which remained intact or superficially damaged. Bark chips on the ground below the tree often signalled the presence of kākā damage. If damage was observed, the type, location, height and extent were recorded. Damage was identified as being present on the lowest, middle and/or top third of the tree and located on the main bole and/or lateral branches. The extent of bark damage was estimated by sight as a percentage of total bark area for each tree. The health of each tree was assessed by estimating the foliage loss and browning as a percentage of the total canopy of the tree.

Up to three tree groups, each of up to ten trees, were sampled at each site. If a damaged tree was not identified after 60 minutes of searching at a site, damage was assumed to be negligible or absent and three randomly selected focal trees and tree groups were sampled.

\subsubsection{Data preparation}

Damaged and undamaged trees were compared for each independent variable using Students t-tests and Fisher's exact test. Exotic and native trees species 
were compared for damage presence and each of the independent variables using Fisher's exact tests and Mann-Whitney U tests.

The distribution of independent variables was assessed using plots and tests for skewness and kurtosis and influential observations and outliers were detected using Cook's and Mahalanobis distances. Variables not normally distributed were transformed. Brix, altitude, DBH, CER, disturbance and bark thickness were $\log _{10}$ transformed.

Collinearity of independent variables was assessed using a matrix of Pearson and point biserial correlations as appropriate for quantitative and dichotomous data (Appendix I Table AI.1). The independent variables were reduced where correlations revealed redundancy. Tree density showed multiple collinearity with six other variables; disturbance $(r=0.325, p<0.001)$, bark thickness $(r=-0.431, p$ $<0.001), \mathrm{DBH}(r=-0.445, p<0.001)$, distance to KWS $(r=-0.190, p=0.017)$, aspect $\left(r_{p b}=0.168, p=0.035\right)$ and tree height $(r=-0.373, p<0.001)$, but was considered the variable least likely to directly influence damage distribution and so was excluded from the model set. Tree height and DBH were highly correlated $(r=0.816, p<0.001)$. DBH was selected to represent tree size in the model set as it was more accurately measured than tree height. Bark type was also excluded from further analysis as it was highly correlated with bark thickness $\left(r_{p b}=0.583\right.$, $p<0.001$ ), a quantitative and more objective measure of bark characteristics. CER and Brix measurements were highly correlated $(r=-0.370, p<0.001)$ so a composite measure of sap solute concentration was formed by summing Brix and an inverse value of CER (Log Brix + (3-Log CER)).

\subsubsection{Model selection and averaging}

An Information-Theoretic (IT) approach was employed to explore factors that influence the selection of individual trees. Most tree species (16 of 31) were represented by fewer than five individuals and damage was found on just 10 of the 31 species sampled. Only those species that were found to have damage were included in the analysis. This resulted in 158 trees of 10 species at 12 sites 
being included in the IT analysis (Table 3.2). Reducing the dataset in this way removed the influential effect of species and focused the analysis on the individual tree characteristics influencing selection.

Variables describing tree characteristics, microhabitat and location were modelled against the binary response variable, presence (1) or absence (0) of sap feeding damage. The IT approach differs from traditional null hypothesis testing by quantitatively ranking and weighting competing hypotheses rather than using an arbitrary probability threshold to assess support for a hypothesis (Burnham \& Anderson 2002). An IT approach is superior to stepwise modelling (Johnson \& Omland 2004; Whittingham et al. 2006) and can be used in conjunction with model averaging to obtain robust parameter estimates (Grueber et al. 2011).

The limited literature on tree selection by kākā and other sap feeding species was insufficient to generate a useful set of a priori candidate models for kākā sap foraging. Therefore, I used an exploratory model averaging approach in which the model suite comprised every possible combination of 1 to 3 fixed-effects. Trees were not independent as they were sampled in groups and multiple groups were sampled per site. Tree group, nested within site, was included as a random effect in all models and in a model without fixed-effects. The random-effect model provides a comparison to evaluate the power of fixed-effects to explain variation in damage at tree, group and site scales. This resulted in 93 models, with each fixed-effect included in 29 of the models (Appendix II).

Akaike Information Criteria were calculated in the way described by Burnham and Anderson (2002) using the statistical software R 2.15.2 (R Foundation for Statistical Computing, Vienna, Austria, 2012). I used second-order Akaike Information Criterion (AICC) as the Information-Theoretic statistic due to small sample size (AICc is recommended when $n / K<40, n=158$ trees, $K=$ number of parameters in the model, Burnham \& Anderson 2002). A preliminary analysis was undertaken of the global model (containing all eight fixed-effects), with and without species as a random-effect and tree group and site as a nested random- 
effect (Table 3.1). This analysis showed that the addition of species as a random effect did not provide additional inference $(\triangle \mathrm{AICC} \sim$ reflecting equal inference and penalisation for an additional parameter). Thus only the site/group randomeffect was included in subsequent analyses.

The candidate models were ranked in order of AICc and relative support was assessed as the difference between each model's AICc and the minimum value from all models $(\triangle \mathrm{AICC})$. Models with $\triangle \mathrm{AICC} \leq 2$ were considered to have substantial support from the data and models with $\triangle \mathrm{AICC}>10$ as having no support (Burnham \& Anderson 2002). Akaike weights $\left(\omega_{i}\right)$ were calculated and used to assess the relative probability of each model. I used model averaging to evaluate the relative importance of each predictor by calculating summed weights for each variable (Burnham \& Anderson 2002).

Table 3.1 Comparison of inference provided by the global model (comprising all eight fixed-effects) with and without each of the two random-effect terms; Site/Group and Species.

\begin{tabular}{lrrrc}
\hline Models & $\mathbf{K}$ & AICc & $\boldsymbol{\Delta}$ AIC & $\boldsymbol{\omega}_{\mathbf{i}}$ \\
\hline Global + Site/Group & 10 & 161.70 & 0.000 & 0.739 \\
Global + Species + Site/Group & 11 & 164.01 & 2.312 & 0.233 \\
Global + Species & 10 & 168.20 & 6.500 & 0.029 \\
\hline
\end{tabular}




\subsection{Results}

\subsubsection{Description of sampled trees and sites}

A total of 282 trees were sampled in 45 groups at 15 sites across Wellington City (Figure 3.3). Between six and 30 trees were sampled at each site. Sampled trees were of 31 different species, 12 of which were not native to New Zealand (Table $3.2)$.

The DBH of sampled trees ranged between 5 and $279 \mathrm{~cm}(\bar{x} \pm S D, 43.4 \pm 45.8)$. Smooth barked trees were more common $(62 \%, n=176)$ than those with rough bark $(38 \%, \mathrm{n}=106)$ and bark thickness ranged between 0.2 and $52.5 \mathrm{~mm}(5.8 \pm$ $6.5 \mathrm{~mm})$. Mean tree height was $17.8 \pm 11.47 \mathrm{~m}$. Measures of sap sugar were highly variable; mean CER was $67.3 \pm 65.6$ k-ohms and mean Brix was $3.2 \pm 2.8$ ${ }^{\circ} \mathrm{Bx}$. Sampling sites ranged from severely exposed (TOPEX 10) to very sheltered (TOPEX 218; $92 \pm 56$ ) with a mean altitude of $167 \pm 95.6 \mathrm{MSL}$. There were on average $0.139 \pm 0.097$ trees per square meter in the 10 meters surrounding each tree. Trees were on average $1.85 \pm 1.09 \mathrm{~km}$ from the KWS fence and $86.5 \pm 78.2$ $m$ from the nearest building or road.

Bark damage was observed on at least one tree at 10 of the 15 sampled sites (67\%), including the 5 sites where damage had been identified prior to sampling. Damage was observed on 85 trees or $30 \%$ of trees sampled of 10 different tree species (Table 3.2). Three of the 19 native tree species sampled and seven of the twelve exotic species sampled had had least one tree observed with damage. Mahoe (Melicytus ramiflorus) was the only native species with more than one damaged tree sampled.

The extent of damage ranged from an estimated $2.5 \%$ to $60 \%$ of bark cover but was predominantly low with $64 \%$ of damaged trees showing between 2.5 and $10 \%$ bark damage. The majority of damage was bark removal in patches (85\%). Transverse gouges were less common (15\%). Only one damage type was found 
on each tree species. Most (73\%) damaged trees had bark removed from the trunk(s) only and in the remaining $27 \%$ lateral branches had also sustained damage. Damage was predominantly found only on the upper third of the tree ( $51 \%$ of damaged trees) and less commonly on both the upper and middle thirds (26\%), or all portions (11\%). In rare cases, damage was found solely on the lower (2\%), middle (9\%) or middle and lower (2\%) thirds of the tree. The majority (60\%) of damaged trees did not appear to have any foliage dieback, although 12 trees had $\geq 20 \%$ foliage loss or browning. No native species were observed with foliage loss or browning.

Exotic tree species were significantly more likely to be damaged than native species (Fisher's exact test, $p<0.001$ ). They also had a higher DBH (MannWhitney $U=1739.5, p<0.001$ ), thicker bark (Mann-Whitney $U=2704.5, p<$ $0.001)$, and lower solute values $\left(t_{206}=-4.932, p<0.001\right)$ than native species. Exotic species were on average found at more exposed sites $\left(t_{277}=-5.551, p<\right.$ $0.001)$, at lower altitudes $\left(\mathrm{t}_{280}=-2.612, p=0.009\right)$ and further from human disturbance (Mann-Whitney $U=6707.5, p<0.001$ ). 


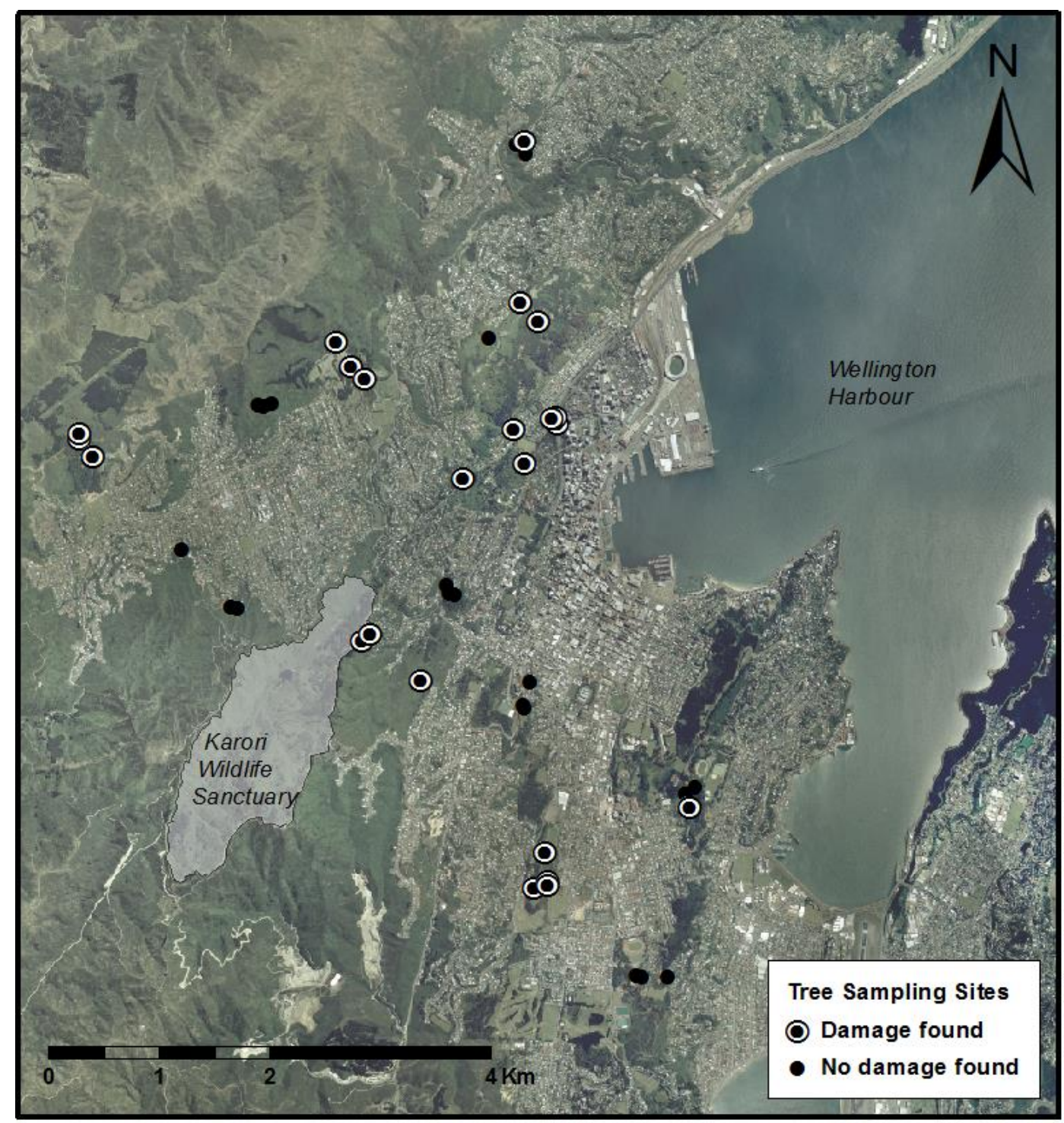

Figure 3.3 Map of Wellington City showing the location of the three groups at 15 sites at which trees were sampled and whether kākā damage was found on at least one tree in the group. A total of 282 trees were sampled. 
Table 3.2 The number of trees of each species sampled that were observed with and without bark damage resulting from sap foraging by kākā.

\begin{tabular}{|c|c|c|c|c|}
\hline Species & & $\begin{array}{c}\text { Trees } \\
\text { without } \\
\text { damage }\end{array}$ & $\begin{array}{c}\text { Trees } \\
\text { with } \\
\text { damage }\end{array}$ & $\begin{array}{c}\% \\
\text { damage }\end{array}$ \\
\hline \multicolumn{5}{|l|}{ Native } \\
\hline Mahoe & Melicytus ramiflorus & 38 & 10 & 21 \\
\hline Kohekohe & Dysoxylum spectabile & 29 & & \\
\hline Five finger & Pseudopanax arboreus & 11 & & \\
\hline Puriri & Vitex lucens & 10 & 1 & 9 \\
\hline Pigeonwood & Hedycarya arborea & 6 & & \\
\hline Kawakawa & Macropiper excelsum & 6 & & \\
\hline Putaputawētā & Carpodetus serratus & 5 & & \\
\hline Cabbage tree & Cordyline australis & 5 & & \\
\hline Mapou & Myrsine australis & 5 & & \\
\hline Hīnau & Elaeocarpus dentatus & 4 & & \\
\hline Kaikōmako & Pennantia corymbosa & 4 & & \\
\hline Fuchsia & Fuchsia excorticata & 3 & & \\
\hline Ngaio & Myoporum laetum & 3 & & \\
\hline Kohukohu & Pittosporum tenuifolium & 3 & & \\
\hline Pohutukawa & Metrosideros excelsa & 3 & & \\
\hline Titoki & Alectryon excelsus & 1 & 1 & 50 \\
\hline Karo & Pittosporum crassifolium & 2 & & \\
\hline Tarata (lemonwood) & Pittosporum eugenioides & 1 & & \\
\hline Kōwhai & Sophora microphylla & 1 & & \\
\hline \multicolumn{5}{|l|}{ Non-native } \\
\hline Macrocarpa & Cupressus macrocarpa & 13 & 35 & 73 \\
\hline Radiata pine & Pinus radiata & 21 & & \\
\hline Lawson cyprus & Chamaecyparis lawsoniana & 3 & 15 & 83 \\
\hline Japanese cedar & Cryptomeria japonica & 3 & 12 & 80 \\
\hline Yellow gum & Eucalyptus leucoxylon & 5 & 2 & 29 \\
\hline Silver birch & Betula pendula & 5 & & \\
\hline Eucalyptus & Eucalyptus sp. (unknown) & 4 & & \\
\hline Stone pine & Pinus pinea & & 4 & 100 \\
\hline English yew & Taxus baccata & & 4 & 100 \\
\hline English oak & Quercus robur & 2 & & \\
\hline Red flowering gum & Corymbia ficifolia & 1 & & \\
\hline Hiba cedar & Thujopsis dolabrata & & 1 & 100 \\
\hline Total & & 197 & 85 & \\
\hline
\end{tabular}




\subsubsection{Model results}

Of the 92 fixed-effects models in the set, more than half received little or no empirical support from the data (Appendix II). Most models outperformed the random effect model. Ten models were unsupported because they ranked lower than the random-effects model, and 46 were implausible ( $\Delta \mathrm{AICc}>10)$. Altitude, distance to KWS and disturbance were highly represented in these low ranking models. There was compelling support $(\triangle \mathrm{AICC} \leq 2)$ for the two highest ranking models in the set. The top ranking model, comprising DBH, solute and TOPEX, received considerable weighting $\left(\omega_{i}=0.231\right)$. DBH and TOPEX were also present in the second ranking model along with aspect. The confidence set $\left(\sum \omega_{i} \geq 0.95\right)$ comprised 24 models in which the variables DBH, bark thickness, solute, TOPEX and aspect were highly represented. Model averaging found that DBH was the parameter that provided the most inference for tree damage $\left(\Sigma \omega_{i}=0.859\right.$, Table 3.3). TOPEX also ranked highly $\left(\sum \omega_{i}=0.740\right)$.

Mean DBH of damaged trees $(\bar{x} \pm \mathrm{SE}, 64.8 \pm 5.2 \mathrm{~cm})$ was twice that of undamaged trees $\left(32.9 \pm 4.5 \mathrm{~cm}, \mathrm{t}_{139}=6.7, \mathrm{p}<0.001\right.$, Figure 3.4a). Topographic exposure values were a third lower for damaged trees $(75 \pm 5)$ than undamaged trees $(118 \pm 6)$, and so damaged trees were found on more exposed sites $\left(\mathrm{t}_{136}=-\right.$ $5.3, p<0.001$, Figure 3.4b). Damaged trees had lower mean solute values $\left(t_{156}=-\right.$ 4.9, $p<0.001$, Figure 3.4c) and thicker bark $\left(t_{127}=5.9, p<0.001\right.$, Figure $\left.3.4 d\right)$ than trees that had not sustained damage. There were no differences between damaged and undamaged trees in aspect (Fisher's exact test, $p=0.205$, Figure 3.4c), distance to Karori Wildlife Sanctuary ( $t_{114}=-1.6, p=0.118$, Figure 3.4f) or distance to anthropogenic disturbance $\left(\mathrm{t}_{156}=1.4, \mathrm{p}=0.164\right.$ Figure $\left.3.4 \mathrm{~g}\right)$. Although altitude ranked low in model averaging analyses, damaged trees were at higher altitudes on average than undamaged trees $\left(t_{156}=1.9, p=0.045\right.$, Figure $3.4 \mathrm{~h})$. 
Table 3.3 Summed Akaike weights of all model containing each fixed-effect.

\begin{tabular}{ll}
\hline Fixed-effects & $\boldsymbol{\Sigma} \boldsymbol{\omega}_{\boldsymbol{i}}$ \\
\hline DBH & 0.859 \\
TOPEX & 0.740 \\
Solute & 0.474 \\
Aspect & 0.339 \\
Bark thickness & 0.246 \\
Distance to Karori Wildlife Sanctuary & 0.097 \\
Disturbance & 0.044 \\
Altitude & 0.041 \\
\hline
\end{tabular}



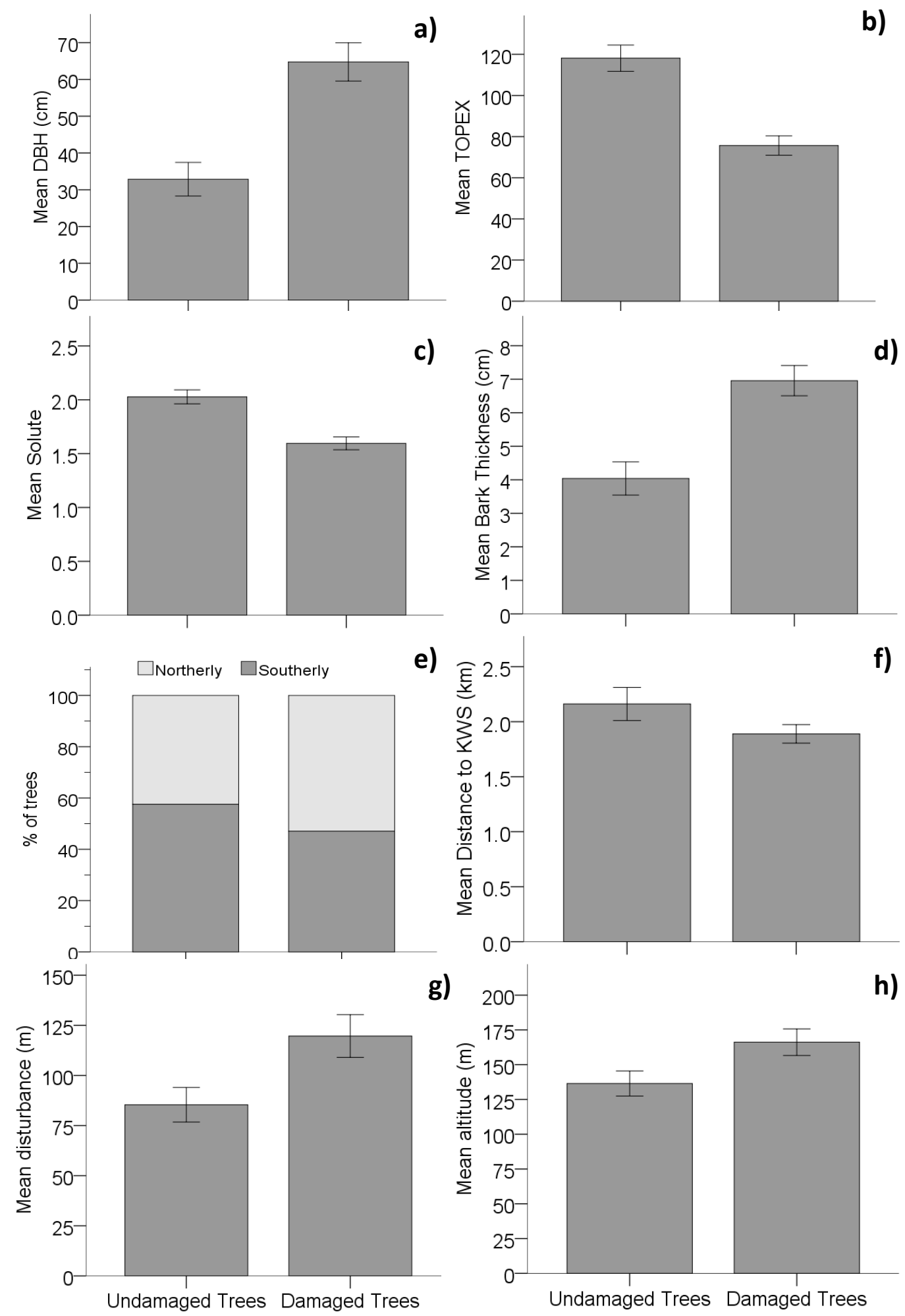

Figure 3.4 Mean $( \pm \mathrm{SE})$ of tree characteristics for trees sampled with and without bark damage. a) Diameter at breast height (DBH, cm), b) Topographic exposure (TOPEX), c) Solute value, d) Bark thickness ( $\mathrm{mm})$, e) Aspect (northerly or southerly), f) Minimum distance to Karori Wildlife Sanctuary fence (km), g) Anthropogenic disturbance (Distance to nearest house or road, m), h) Altitude (MSL). 


\subsection{Discussion}

Sap foraging kākā preferentially select trees for sap feeding based on tree characteristics and species. Trees damaged by kākā in Wellington City are more likely to be exotic species, particularly conifers that are large and found at exposed sites, such as on ridges and hillsides rather than in valleys.

\subsubsection{Characteristics of trees selected for sap feeding}

Tree size appears to be influential in the selection of trees for sap foraging by kākā. Diameter at breast height was the most informative characteristic for predicting bark damage and was highly correlated with tree height. Sap feeding damage was more likely to be found on taller trees with a wider girth. No significant relationship between kākā bark damage and tree diameter has been found previously, although in south Westland there appeared to be a trend towards sap feeding on larger trees (O'Donnell \& Dilks 1989). Selection for larger trees is common to many sap feeding species (Eberhardt 2000; Pejchar \& Jeffrey 2004; Eyre \& Goldingay 2005; Schlatter \& Vergara 2005; Kozma 2010). Although it has been suggested that larger trees may have more concentrated sap due to a greater surface area for photosynthesis (Pejchar \& Jeffrey 2004), a negative correlation between the measure of sap solutes and tree size in this study suggest that this is not always the case. Nevertheless increased hydrostatic pressure may lead to faster sap flow in taller trees (Crafts \& Crisp 1971) and this may result in sap exuding faster or in greater quantities at bark wounds. Kākā predominantly forage in canopy trees (O'Donnell \& Dilks 1994) and kākā were observed foraging in sap feeding trees during this study. Hence, preference for sap foraging in larger trees may also reflect the availability of other food resources or a general preference for being higher in the canopy.

Topographic exposure was the second most influential characteristic of tree selection. Trees on more exposed sites more likely to be damaged. In Wellington City, large areas of the Town Belt that contain some of the larger emergent trees 
are also predominantly found on ridges and steep hillsides. Hence, kākā preference for sap feeding on exposed sites may be an artefact of town planning. It may also reflect the topography of Wellington City and the way kākā use the landscape. Kākā may fly across rather than descending into valleys and so may be more likely to forage on hillsides and ridges. There may be particular characteristics of exposed sites however, that result in their selection as sites for sap feeding. Trees on more exposed sites may have higher rates of photosynthesis, transpiration and nutrient transport due to full sun for most of each day (Holbrook \& Zwieniecki 2005), which may lead to faster flowing or more concentrated sap. Pejchar and Jeffery (2004) suggested that the preference of the 'akiapōlā'au to forage for sap on trees on convex slopes may be due to their increased photosynthetic rates. Whether slopes were north or south facing, however, was not found to influence kākā tree selection, suggesting that direct sunlight may be not have an important impact on tree selection. Foraging at exposed sites may also be a consequence of kākā social behaviour. For example, calls from trees at exposed sites may be heard from further away.

Sap solute concentration provided some inference for tree selection but the relationship between solute concentration and bark damage was negative not positive. This may be because sap is such a highly concentrated source of energy that variation in sugar content is not within the range that kākā detect or select for. Lower solute values in damaged trees may also be because larger trees have more dilute sap, as suggested by inverse correlations between solute and both DBH and height. Sap volume and solute concentration may vary diurnally and seasonally (Goldingay 1987, 1991; Eyre \& Goldingay 2005), and kākā may be responsive to fine scale changes in sap solute concentration that were not captured in this study. It is also possible that the lower solute concentrations of sap from damaged trees may be a consequence of sap feeding. It has been suggested that damage caused by yellow-bellied sapsuckers influences the composition of the damaged tree's sap (Eberhardt 2000). 
Although there was a significant difference in mean bark thickness between damaged and undamaged trees, bark thickness does not appear to be an important influence on tree selection by kākā. The higher mean bark thickness of damaged trees is likely to be due to the strong correlation between bark thickness and tree size. Kākā have a large strong beak that can excavate invertebrates from live wood (Beggs \& Wilson 1987) so thick bark is unlikely to be a substantial barrier, particularly when it can be removed in layers or strips.

Disturbance, measured as the distance between the sampled tree and the nearest building or road, was also not influential. Despite the availability of large greenspaces in Wellington, kākā did not appear to preferentially forage for sap away from human activity. Kākā were also no more likely to feed closer to KWS, indicating that proximity to their reintroduction site and its supplementary food does not limit sap feeding.

\subsubsection{Tree species selection for sap feeding}

Tree species appears to be an important factor in selection of sap foraging trees. Many exotic tree species that were highly damaged in Wellington City were conifers, including macrocarpa, Lawson cyprus (Chamaecyparis lawsoniana) and Japanese cedar (Cryptomeria japonica). Others have observed that conifer species may be generally favoured by kākā (Beaven 1996) and the majority of conifers in the Wellington area are exotic species. Mahoe was the predominant native species found damaged. It is not known if these species were preferentially selected for sap feeding or were damaged in large numbers because they are more available. However, it is evident that some preferential selection of sap feeding trees is occurring. For example, radiata pine, kohekohe (Dysoxylum spectabile) and kawakawa (Macropiper excelsum) are common in Wellington City but were never observed with bark damage. Conversely, many rare tree species such as Japanese cedar (Cryptomeria japonica) and stone pine (Pinus pinea) were damaged. 
The exotic tree species sampled in this study were larger and were found at sites that were more exposed. Kākā may be more likely to fed on exotic species in part because they are selecting for these characteristics. Sap from exotic tree species may also be more accessible, higher quality, or be available in larger quantities. Native species have coevolved with kākā and so may have developed strategies to discourage sap feeding, such as defensive compounds in their sap or bark. Exotic tree species may lack similar defence mechanisms if other sap feeding species were not present during their evolutionary history and therefore these tree species may present a more attractive resource. Future studies comparing tree species use in relation to availability may provide a greater understanding of patterns of species selection.

Kākā appear to target conifers (Division: Pinophyta) for sap feeding. In this study, half of the species observed with damage and over $80 \%$ of the individual trees observed from damaged species were conifers. Native and exotic conifers were favoured in a previous study of kākā sap feeding (Beaven 1996) and observations in a range of forest types elsewhere in New Zealand have found damage to native conifer species (Bernard Smith, Karori Sanctuary Trust, pers. comm.; O'Donnell \& Dilks 1989; Berry 1998). Gymnosperms lack the p-proteins that plug sieve plates of damaged phloem cells of angiosperms sealing off wounds in the event of injury (Beck 2010). Hence sap may be exuded for longer from bark wounds in conifers than angiosperm species.

Rather than, or in addition to, preferentially selecting species on which to forage for sap, kākā may avoid trees based on species or individual characteristics. For example, no damage was found on radiata pine although it is a conifer and is present near to phylogenetically and phenotypically similar species, such as macrocarpa, that were heavily damaged. Kākā may avoid radiata pine due to characteristics such as secondary compounds in bark or sap that discourage feeding (e.g. Ku et al. 2007). 


\subsubsection{Sap feeding damage}

Bark damage to trees sampled in this study was predominantly minor, however some trees were extensively damaged, with damage covering major branches and the trunk down to a few meters above ground level. This may reflect 'testing' of trees to identify the best sites for sap feeding. Initially, a few removed bark patches or gouges may be formed in a tree and kākā may then frequently return to favoured trees for subsequent feeding. The majority of sap feeding scars were found on the upper third of a tree's trunk. This is similar to what has been found elsewhere in New Zealand (Innes 1994; Beaven 1996). Bark thickness reduces with height above the ground (Innes 1994) and sugar concentrations may be higher near the top of a tree as solutes are transported from photosynthetic tissues to the growing tree crown and branch tips (Innes 1994).

Only one of the two types of bark damage was observed on each tree species, suggesting that damage type may be linked to bark characteristics. The properties of bark, such as thickness, hardness and grain, would impact on the most efficient way to access the sapwood. In species that had patches of removed bark, such as Lawson cyprus and stone pine, bark is flaky and can be removed in strips. In species where bark did not come off in layers, transverse gouges were seen. These included thicker barked species such as Eucalyptus spp. and very thin barked species such as mahoe.

Bark damage may negatively impact tree health. Forty percent of damaged trees had some degree of foliage dieback or loss, although this cannot be attributed with certainty to bark damage caused by kākā. It is possible that dieback was underestimated as the canopy foliage of some trees was not able to be viewed easily from the ground. The impact of bark damage on tree health appears to differ between tree species. For example, the four English yew (Taxus baccata) trees sampled in this study had low levels of damage but had heavy dieback, possibly due to pathogen infection that may have resulted from bark removal 
(James Jones, pers. comm.) No native species were observed with foliage browning or loss, even mahoe, despite extensive bark damage. Native species have co-evolved with kākā and so it is possible that these species have evolved strategies that reduce the negative impacts of bark damage.

\subsubsection{Limitations and further research priorities}

The characteristics of trees and sites measured in this study were chosen based on observations of kākā sap feeding damage in Wellington City and literature from studies of tree selection by other sap feeding species. There may be characteristics important in tree selection that were not investigated in this study. For example, resource distribution, including supplementary anthropogenic food, may influence kākā distribution across the landscape and hence impact on where kākā forage for sap. Further studies could also investigate the role of secondary compounds in sap as they may play a role in tree selection (Pejchar \& Jeffrey 2004).

In this study, I was not able to directly measure sap sugar concentration or measure sap latency, quantity or duration of sap flow, since I could not generate a flow of sap by removing bark or incising phloem tissue. This has been a challenge common to other sap feeding studies (Eberhardt 2000). Cambial electrical resistance (CER) gives a measure of the solute availability in phloem tissue and has been used in previous tree selection studies (Mackowski 1988; Eberhardt 2000), however it also captures variability in phloem width, moisture, and growth rate (Carter \& Blanchard 1978; Plamping et al. 2008). CER is also confounded by variables such as tree age, seasonality and temperature which may limit its utility for comparisons between plant species and localities (Plamping et al. 2008). Although carbohydrates are the main component of sap (Holbrook \& Zwieniecki 2005), testing dissolved sugars in phloem tissue using a refractometer may also have captured variation in other solutes. Despite the limitations of these methods, they were the most accurate methods possible as direct measures of sugar content of sap or phloem tissue could not be obtained. 
Factors that influence the availability of sap, such as latency, quantity and duration of sap flow may have a considerable impact on the energy available from sap foraging, regardless of concentrations of solutes, and may also be influential in kākā sap tree selection. Kākā may select trees that produce more sap or continue to produce sap for a longer period of time. Trees used for sap feeding by the 'akiapōlā'au did not differ in solute concentration from unused trees, but selected trees produced more sap and sap flowed for longer (Pejchar \& Jeffrey 2004). Measurements of volume, latency or duration of sap flow were not possible as a flow of sap could not be obtained.

Damage is likely to have been underestimated in this study as damaged trees may have been overlooked or damage may not have been visible from the ground. Nevertheless, undetected damaged is unlikely to have biased the outcomes of the tree selection analyses since tree characteristics most likely had minimal impact on damage detectability.

The lack of previous data on kākā sap feeding and tree selection necessitated the exploratory approach used in this study. Subsequent studies should use the models supported here as the basis for candidate model set development and stronger inference. Comparison of tree selection in forest habitats would also be valuable to investigate if similar characteristics determine the distribution of damaged trees across landscape types.

Due to the diversity of plant species and landscape types in the urban environment, further sampling would be valuable to better understand the distribution of damage. For example, systematic sampling did not take place within KWS, although damage has also been observed there (Charles 2012). The low number of sampling sites in this study limited the inference that could be made at the landscape level and further research could investigate factors that influence the spatial distribution of damage. This could be coupled with a study understanding how kākā use the urban landscape and their utilisation of other resources in addition to sap. 
Further research into the effect of bark damage on tree health would be a valuable extension to this study and would provide a better understanding of the potential impacts of kākā sap feeding in urban areas. Negative impacts of bark damage such as foliage dieback and pathogen infection appear to vary between species and individual trees. Observations during this study suggest that trees nearing senescence or experiencing other environmental stressors may be less able to tolerate bark damage and native species may be more resilient. Since the impacts of bark damage on tree health, particularly the resulting safety risks, are the causes of conflict with people, understanding the links between bark damage and tree health may assist in managing the emerging conflict with kākā.

\subsubsection{Management recommendations}

Monitoring damaged trees is important as bark damage can increase the likelihood of structural failure- a hazard in a peopled landscape. Monitoring trees for bark damage can be time-consuming and costly so should be targeted to trees most likely to sustain damage and in areas where damaged trees may pose a risk. This study shows that damage monitoring should focus on large conifers, such as macrocarpa and Lawson cypress, at exposed sites as these are most likely to sustain considerable bark damage.

Long term management of the effects of kākā sap feeding should focus on planting species that are favoured for sap feeding yet resilient to bark damage. Although further research into species' resilience is required, this study suggests that native species may be less likely to be negatively affected by bark damage. Species that are negatively affected by bark damage should be avoided for new plantings; including Lawson cypress, English yew and rare conifer species such as stone pine, Japanese cedar and hiba cedar (Thujopsis dolabrata). This information will be valuable for Wellington City Council and Wellington Regional Council planting plans and should be communicated to Wellington residents. This will enable informed decisions to be made about tree species selection on both 
council and privately-owned land, and may reduce the negative impacts of kākā tree damage and kākā-human conflict in the long term.

As part of a gradual conversion to native species, many large exotic trees are being removed from the Wellington Town Belt (Wellington City Council 2012b). The trees targeted for removal include large conifers, such as macrocarpa, on exposed ridges and hillsides, the same trees that kākā appear to favour for sap feeding. A loss of sap feeding resources in the Town Belt may lead to an increase in sap feeding in areas where it has greater impact on people, such as in residential areas. Hence it may be useful to retain some large conifers until alternative resources for sap feeding are established. 



\section{Chapter Four: Behaviour and characteristics of sap feeding kākā}

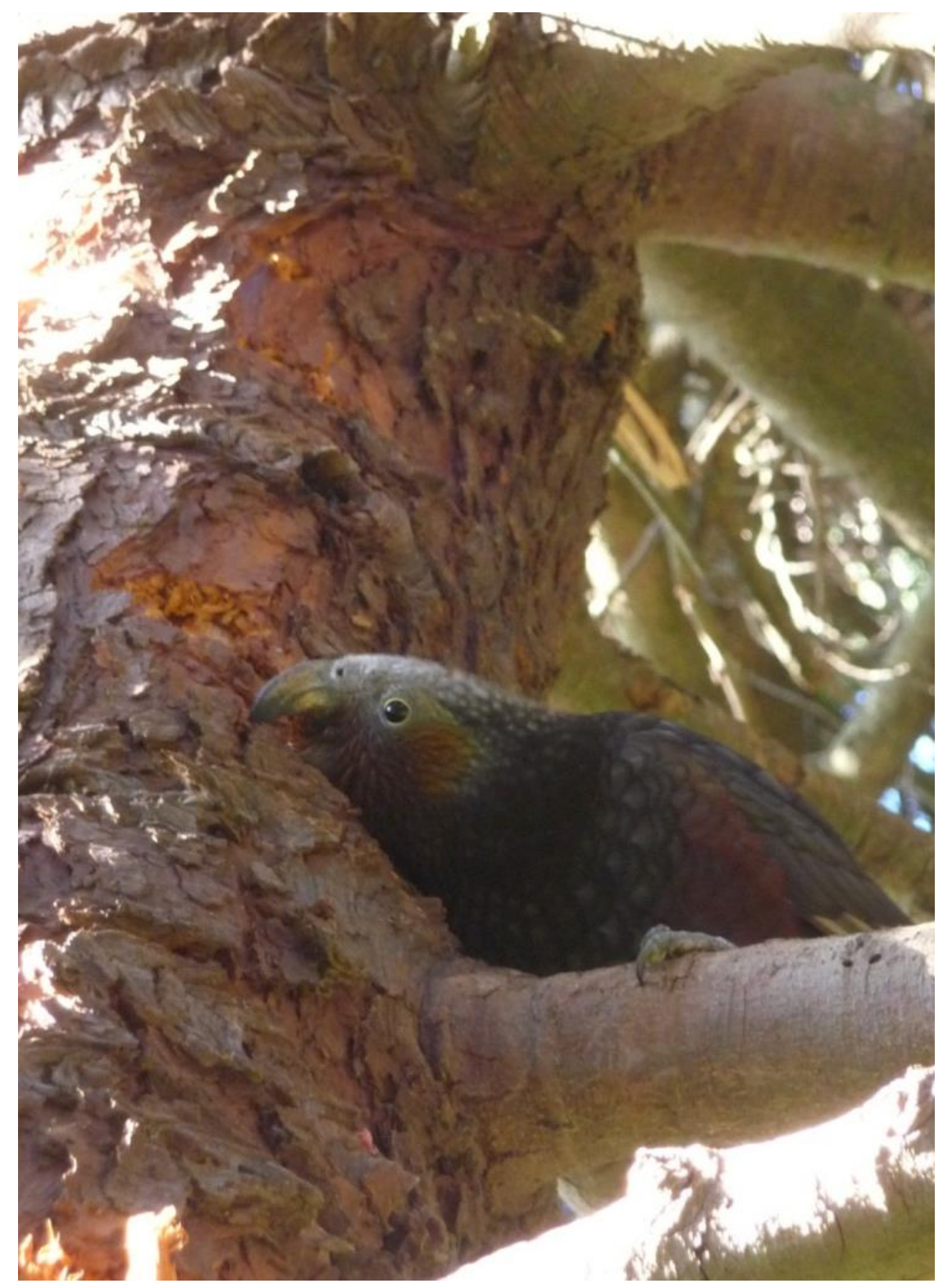

A kākā foraging for sap on macrocarpa (Cupressus macrocarpa), at Karori Cemetery, Karori, Wellington 


\section{Abstract}

Kākā (Nestor meridionalis) feed on phloem sap by removing tree bark, a rare behaviour among vertebrates. In Wellington City, sap foraging occurs on native and exotic trees, and the resulting damage is leading to conflict with residents. Little is known about the sap foraging behaviour of kākā as previous studies have been restricted by small sample sizes and limited demographic information about sap feeding birds. This study aimed to gain a greater understanding of kākā sap feeding behaviour and to test hypotheses that sap feeding is predominantly a female activity and that one type of sap foraging, forming transverse gouges, is restricted to adult kākā. I used instantaneous scan sampling to record the behaviour of kākā at 1-minute intervals during 25 60-100 minute observation periods at Anderson Park, Wellington Botanic Garden in August and September 2012, and during 12 opportunistic observations of sap feeding kākā in Wellington City from November 2011 to November 2012. Forty observations of sap feeding were made of 20 individually-identified birds. Sap feeding birds were predominantly young, eight (40\%) were juveniles (fledged in 2011/12) and seven (35\%) fledged in the preceding season (2010/11), reflecting the higher proportion of young birds in the population. All sap feeding birds of known sex were female $(n=6)$, however based on estimated sex, females were no more likely to sap feed than males (exact binomial test $p=0.916$ ). Nineteen of the 20 identified sap feeding kākā utilised supplementary feeding stations at ZealandiaKarori Wildlife Sanctuary. Kākā were observed displacing conspecifics and defending sap feeding sites from tui (Prosthemadera novaeseelandiae) and conspecifics. These results do not support hypotheses that sap feeding is predominantly a female behaviour or that it is restricted to adult birds. Sap appears to be an important resource for kākā across sexes and life stages, and provision of supplementary food is unlikely to reduce sap feeding and tree damage in Wellington City. 


\subsection{Introduction}

\subsubsection{Kākā foraging behaviour}

Kākā (Nestor meridionalis: Nestoridae) have a diverse diet and a large repertoire of foraging techniques (O'Donnell \& Dilks 1994). They have been termed sequential specialists as they move between different food sources, including invertebrates, nectar, seeds, fruits and sap, over the course of the year (O'Donnell \& Dilks 1994). Kākā are highly mobile and will move between forest patches across a large altitudinal range to exploit food availability at different times of year (O'Donnell \& Dilks 1994). Kākā may forage solitarily or congregate in large groups at a food source (Moorhouse 1991; Moorhouse 1997).

Kākā exhibit moderate dietary differentiation between the sexes (Greene et al. 2004). Fruit and burrowing invertebrates make up a larger proportion of the diet of males while females eat more nectar, sap and surface dwelling invertebrates (Greene 2004). Kākā exhibit sexual dimorphism in beak size. Males have a significantly longer and larger upper mandible than females which may result in differential foraging ability (Beggs \& Wilson 1991; Moorhouse et al. 1999). Kākā have a monogamous mating system and males provision females and young. The larger bill of males may enhance male provisioning ability (Moorhouse et al. 1999).

Kākā use a number of specialist foraging strategies. A high percentage of feeding time is spent digging into wood and bark to extract invertebrates. On Kapiti Island kākā spent a minimum of $40 \%$ of observed foraging time searching for and excavating insects in wood or bark (Moorhouse 1997). Wood and bark-dwelling invertebrate foraging was also the most frequent foraging activity in broadleaved rainforest (O'Donnell \& Dilks 1994) and in temperate beech (Nothofagus spp.) forest (Beggs \& Wilson 1991). Kākā also feed on sap by peeling off strips or gouging grooves into tree bark. Sap is an important food for kākā and considerable time may be spent foraging for this food resource (O'Donnell \& 
Dilks 1989; Beaven 1996). No other New Zealand bird is known to remove bark to feed on sap. Knowledge of this foraging strategy is currently limited and this behaviour is the focus of my study.

\subsubsection{Sap feeding}

Removing bark in order to feed on sap is a specialised behaviour that is rare among vertebrates (Snyder 1992). Species known to feed on sap include marsupial gliders (Petaurus spp., Smith 1982; Mackowski 1988; Goldingay 1991), marmosets (Family: Callitrichidae, Coimbra-Filho \& Mittermeier 1976; Lacher et al. 1984), squirrels (Sciurus spp., Kenward 1982; Kenward et al. 1988; Heinrich 1992; Snyder 1992), woodpeckers (Subfamily: Picinae, Tate 1973; Blendinger 1999; Eberhardt 2000; Kozma 2010), and a few other bird species (Hemignathus munroi, Pejchar \& Jeffrey 2004; Diglossa lafresnayii, Martin et al. 2009), including the kākā. A wider range of species will feed on sap from bark wounds produced by other species (Chapman et al. 1999).

In order to feed on sap, an animal must remove the outer bark layer of a tree to expose the living phloem tissue. Bark is a non-technical term referring to an outer tissue layer, the rhytidome; consisting of secondary (dead) phloem and periderm, and an inner layer of living phloem tissue (Beck 2010). Successive layers of periderm develop around secondary phloem to form the rhytidome and differences in the structure and formation of the rhytidome result in the bark differences that are apparent between plant species, such as thickness, furrowing, and type of exfoliation (Beck 2010). A sap feeding animal must breach the rhytidome layer to access the live phloem tissue. Phloem tissue consists of conducting cells, collectively known as sieve elements; and non-conducting parenchyma and supportive cells (Beck 2010). Conducting cells carry sap, a water-based solution that functions primarily to transport photosynthetic products from the site of photosynthesis to areas where it is utilised or stored. Sap movement is the result of hydrostatic pressure and is bidirectional, although solute moves predominantly downward from leaves to growing areas or storage 
organs (Beck 2010). Sucrose is the principal solute component in many plant species, but glucose, fructose and raffinose are also common (Innes 1994; Pate et al. 1998). Sap also contains high levels of free amino acids, and small quantities of hormones and minerals, such as potassium, calcium and sodium (Innes 1994; Douglas 2006; Beck 2010). Phloem sap varies in composition diurnally and seasonally, with plant development, and with abiotic factors such as temperature and water availability (Douglas 2006).

Since sap is poorly defended chemically in comparison to other plant tissues (Douglas 2006), the bark layer provides the main defence against herbivory. However, the sap of angiosperms contains P-proteins that quickly plug conducting cells in the event of injury, and phenolic compounds in the phloem of many conifer species play an important defence role (Beck 2010).

A number of sap-feeding species have been studied and demonstrate the range of behaviours associated with this type of foraging. The yellow-bellied glider (Petaurus australis) forages nocturnally for sap by incising small v-shaped holes in the trunks of Eucalyptus trees (Goldingay 1987). Usually only a single tree in a stand is selected and used repeatedly over a number of seasons (Kavanagh 1987; Mackowski 1988). Sap is an important food source for the yellow-bellied sap sucker (Sphyrapicus varius), a North American woodpecker, particularly during the breeding season when nestlings are fed insects dipped in sap (Eberhardt 2000). The yellow-bellied sap sucker drills numerous holes into the trunk of a tree, precisely patterning new sap holes above previous ones to 'girdle' sap, increasing the sap available for feeding (Eberhardt 2000). Sap-suckers may drill wells in the morning then return to feed in the afternoon when sap flow peaks (Long 2011). This species uses a variety of tree species sequentially across the year (Tate 1973). The 'akiapōlā'au (Hemignathus munroi), a Hawaiian honeycreeper, appears to cultivate increased sap flow in a similar way to the sapsucker, by drilling horizontal rows of holes and drilling above previous holes (Pejchar \& Jeffrey 2004). Sap-feeding trees are used across multiple generations 
by the 'akiapōlā'au (Pejchar \& Jeffrey 2004). Most sap feeding species forage solitarily, however the magellanic woodpecker (Campephilus magellanicus) has been observed foraging for sap in family groups with fledglings feeding from wells drilled by adults (Schlatter \& Vergara 2005).

Species that remove bark in order to feed on sap can have an important role in facilitating access for other species to this food resource. Sixteen species of birds were recorded foraging at sap sites of yellow-bellied gliders, either feeding on the sap exuding from wounds or on insects that were attracted to the sap (Chapman et al. 1999). Chapman (1999) found complex interspecfic interactions occurring between birds at sap sites, with dominant (usually larger) birds defending sap scars and displacing other birds, and stronger beaked birds facilitating sap feeding by maintaining the flow of sap. Similarly, sap from holes produced by white-fronted woodpeckers was an important food resource for a range of bird species in the Monte Desert, Argentina (Blendinger 1999). Although white-fronted woodpeckers actively defended their feeding holes from other birds, sap made up a significant proportion of the diet of a number of species (e.g. $80 \%$ of foraging observations of monk parakeet were of sap feeding). Species that make sap accessible may play important roles as keystone species in these communities (Chapman et al. 1999).

\subsubsection{Kākā sap feeding}

Although well-known anecdotally, sap feeding by kākā has been the subject of few studies. Previous descriptions and studies of sap feeding in the literature have been limited by small sample sizes, with a maximum of four sap-feeding individuals identified (Beaven 1996), and little demographic information for observed birds has been available.

Beaven (1996) studied kākā sap feeding and resulting tree damage in exotic plantations and adjoining native forest in Whirinaki, Bay of Plenty. Six birds were tracked and sap feeding was found to comprise $24 \%$ of total feeding observations, although there was considerable variation between individuals. 
Sap feeding was observed predominantly on Douglas fir (Pseudotsuga menziesii) and tawa (Beilschmiedia tawa) and bark damage in plantations was restricted to exotic trees within $1 \mathrm{~km}$ of native forest.

O'Donnell and Dilks (1989) observed sap feeding on southern rata (Metrosideros umbellata) in south Westland. They described how kākā would bend a flap of bark downward forming a 'trapdoor' and then gouge a series of holes into the cambial tissue to obtain sap. Trapdoors were arranged in horizontal rows and were found at any height on the trunk and main branches. They described a bout of sap feeding by two kākā lasting 57 minutes. An average of 6.6 minutes (range $1-12, n=7$ spells) was spent prising open bark and 1.8 minutes on average was spent lapping sap (range 1-3, $n=6$ spells). Scars were revisited numerous times, with one receiving at least four visits during the observation period. These 'trapdoor' marks have also been observed on tōtara (Podocarpus totara) in south Westland (Bernard Smith, Karori Sanctuary Trust, pers. comm.), however no trees in Wellington City have been observed with similar markings (Charles 2012).

Depending on the time of year, sap can form a minor or major part of the diet of kākā. Sap comprised 3\% of the kākā diet over the course of a year in Westland, but the majority of sap feeding occurred in late winter to early spring (O'Donnell \& Dilks 1989, 1994). At Mt Bruce Reserve in the southern North Island, sap feeding was only observed in August and September (Berry 1998). At Whirinaki, bark damage peaked from September to November and again from February to March (Beaven 1996). An individual kākā tracked from September to December spent $92 \%$ of observed foraging time sap feeding (Beaven 1996). Late winter and early spring is a time when there may be little nectar or flower sources available and energy needs are high due to low temperatures and the onset of breeding (Weathers et al. 1984; O'Donnell \& Dilks 1994) so sap may provide a source of high-energy food during this period (Beggs \& Wilson 1987; O'Donnell \& Dilks 1989). Beaven (1996) found that sap feeding occurred when other foods were 
not in short supply, suggesting that sap feeding may be linked to seasonal increases in sap sugar content rather than food shortage. Sap flow increases in early spring so sap may also be more easily accessible at this time of year (O'Donnell \& Dilks 1989). Seasonal differences in the timing of sap feeding in native and exotic forest may reflect variation in the timing of peak sap flow or sugar levels in the different tree species (Beaven 1996).

Sap feeding appears to be predominantly a female behaviour. Sap feeding was only observed in females on Kapiti Island (Moorhouse 1997) and at Mt Bruce (Berry 1998). Two female kākā were observed spending 40\% of their time in winter feeding on sap from mountain beech (Nothofagus solandri var. cliffortioides) (Beggs 1988). The only observation of a male feeding on sap was at Whirinaki where bark stripping accounted for $2.6 \%$ of observed foraging time for this bird and $98 \%$ of bark stripping observations were of the two tracked females (Beaven 1996). Sap may provide an important source of high-energy food for females prior to breeding (Beaven 1996). It has been speculated that female kākā may use hormonal indicators or increased nutrient content in sap to predict mast seed production and hence trigger the onset of breeding (Moorhouse 1997; Wilson et al. 1998). Restriction of sap feeding to one sex is not known in any other sap feeding species.

Sap foraging may also be restricted to older individuals. At Mt Bruce, older females spent considerable amounts of time forming distinctive horizontal groves in tree trunks whereas younger birds would follow them and lick at sap (Berry 1998). Since only older females were observed using specialised horizontal sap tapping techniques, Berry (1998) suggested that this type of sap foraging may be a learned skill that is acquired with age (Berry 1998). Restriction of bark removal to older kākā may also reflect insufficient muscle or beak strength of young birds, or lower need for high-energy sap among non-breeding birds. No studies of kākā or other sap feeding species have considered the age of sap feeding individuals. 
There is little known about possible interspecific interactions that may occur at sap wounds formed by kākā. I have found no evidence in the literature of other species feeding on sap from wounds produced by kākā. Tui (Prosthemadera novaeseelandiae) have been observed to associate with kākā while feeding on invertebrates (Medway 2005), and have been described as feeding on sap exuding from damaged branches (Dilks 2004) but there is no reports of tui or other bird species associating with kākā to take advantage of sap availability at the bark wounds created.

\subsubsection{Study population}

North Island kākā (Nestor meridionalis septentrionalis) were reintroduced to Wellington City in August 2002 with the release of six captive-reared kākā to Zealandia-Karori Wildlife Sanctuary (hereafter KWS, $41.290^{\circ} \mathrm{S} 174.753^{\circ} \mathrm{E}$, Miskelly et al. 2005). Subsequent translocations and considerable breeding success have led to a current estimated population in the Wellington area of approximately 180-250 birds (Karori Sanctuary Trust, unpubl. data).

The age of chicks that fledge from artificial nest boxes provided within the sanctuary is known and they are fitted with individually-identifiable coloured leg bands. The first confirmed kākā nest outside of KWS was found in December 2012 (Wannan 2012), however increasing numbers of unbanded kākā appearing in recent years suggest that nesting outside the sanctuary may have occurred in previous seasons (Raewyn Empson, Karori Sanctuary Trust, pers. comm.). It is also likely that some unbanded kākā are immigrants from populations outside of Wellington City.

Due to recent reintroduction and breeding success there is a higher proportion of young birds than adults in the population. The sex ratio for males and females of confirmed sex $(n=97)$ does not differ significantly from 0.5 (Karori Sanctuary Trust, unpubl. data), suggesting that there is a relatively balanced sex ratio in the Wellington City population as a whole. 


\subsubsection{Aims}

This study aimed to provide a greater understanding of sap feeding in kākā by describing and quantifying their sap feeding behaviour. I developed an ethogram and undertook systematic observations of kākā engaged in sap feeding behaviours. Small sample sizes in previous studies have limited the inferences that can be drawn and hypotheses have been largely speculative. This study aims to collate a larger sample of observations and to investigate hypotheses about sap feeding by utilising demographic data of individually identifiable birds in the population. I aimed to test hypotheses that sap feeding is predominantly restricted to female kākā (Beaven 1996; Moorhouse 1997; Berry 1998) and that more specialised horizontal gouging methods of extracting sap are restricted to older birds (Berry 1998).

\subsection{Method}

\subsubsection{Observations of kākā behaviour}

An ethogram of behavioural categories and their definitions was developed from preliminary ad libitum observations of kākā behaviour in the trees of public parks, gardens and bush fragments (hereafter greenspaces) in Wellington City. An ethogram is a comprehensive description of the characteristic behaviours of a species and provides a starting point for behavioural research (Lehner 1996). The ethogram was developed as device for studying the focal behaviour, sap feeding, and so is not an exhaustive list of all kākā behaviours. Some behaviours that were of less interest for this study (e.g. social interaction) were grouped into larger behavioural categories for analytical purposes and ease of data collection.

Behavioural observations were made in the Anderson Park area of the Wellington Botanic Garden $\left(-41.279^{\circ} \mathrm{S}, 174.770^{\circ} \mathrm{E}\right)$, as preliminary observations of kākā and tree damage indicated that this area was frequented by kākā. Observations began approximately one hour before sunset and ended when 
poor light prevented accurate observation. Observations were made 4-5 days per week over a six week period between mid-August and late-September 2012. This time of year was chosen as previous studies had shown this was a time of high sap feeding and anecdotal observations indicated this may be true in Wellington also.

The locations of kākā in the area were identified by kākā vocalisations or searching visually and the focal tree was chosen as the first tree in which kākā were observed. An instantaneous scan sampling method was used (Altmann 1974), whereby the behaviour of the focal bird was classified into one of the behavioural categories at 1-minute intervals. If more than one kākā was present, one was randomly selected as the focal bird. The behavioural category, presence of conspecifics, food being consumed, and vocalisations made were recorded. Leg band combinations of the focal bird and other birds present in the same tree were recorded. Observations were made consecutively until the bird was no longer in view (i.e. the bird moved away or it became too dark to clearly see behaviour). If other individuals were present in the area when the focal bird left, a new focal bird would be randomly selected and behaviour sampling would continue. If no observations of kākā were made, searching was ceased after 60 minutes. The presence of an observer was assumed to have little effect on focal bird behaviour as human presence and movement were common in the observation area and birds did not appear to be disturbed by the observer or other humans during observations.

Observation was preferentially made of sap foraging, the focal behaviour. Observations of a focal bird that was not sap feeding were ceased if another bird began sap feeding, and that bird became the focal bird. This bird was observed until it moved out of view or if it ceased sap feeding and another bird started. Observations of sap feeding were added to the sap feeding dataset (Section 4.2.2). 


\subsubsection{Observation of sap feeding behaviour}

In addition to the systematic behavioural sampling described above, observations of kākā engaged in sap feeding were made opportunistically over the course of the study between November 2011 and November 2012. Due to the rarity of observing sap feeding and the difficulty of predicting where and when it would occur, opportunistic focal behaviour sampling was adopted, allowing as many observations as possible to be included in the study. Whenever a kākā was observed removing bark from a tree it became the focal bird and sampling began. An instantaneous sampling method (Altmann 1974) was used where the behaviour occurring at 1-minute intervals was recorded. Sampling continued until the bird left the area or until the sap feeding bout ended and other behaviours were observed for at least 10 minutes. The leg band combinations of the focal bird and any nearby conspecifics were identified. The time and date, location, weather and tree species being fed on was also recorded. Other behaviours were noted, including conspecific and heterospecific interactions and vocalisation.

Observations of sap feeding occurred during systematic behaviour sampling at the Wellington Botanic Garden (Section 4.2.1), in other greenspaces around Wellington during fieldwork for Chapter Three, and as a result of alerts to sap feeding behaviour by members of the public. Two local residents approached me in response to requests for information about kākā damage and allowed me to observe kākā sap feeding on their properties. Two observations of sap feeding were supplied by a staff member and volunteer of Karori Sanctuary Trust and were judged to be reliable descriptions.

Observations were collated and analysed to produce a description of sap feeding behaviour. Records obtained from Karori Sanctuary Trust were used to determine the age (season fledged) and sex of identified birds (Karori Sanctuary Trust, unpubl. data). Sex categorisation was based on behavioural observation during breeding or predicted using a model based on discriminant function 
analysis of nestling body measurements and able to predict sex from nestling measurement data to 83\% accuracy (Karori Sanctuary Trust, unpubl. data). Measurements of weight; wing, tail and tarsus length; and beak length and width were taken from chicks when leg bands were fitted prior to fledging, approximately 38 to 48 days after hatching. Males tend to be larger, however there is an overlap with females, and smaller males are often within the range of females (Judi Lapsley Miller, pers. comm.). Sex is only confirmed based on observation of courtship and breeding behaviour or post-mortem. Sex prediction analysis was conducted by Judi Lapsley Miller, a volunteer at KWS. The estimated sex was used for the 12 sap-feeding individuals with fledgling data for whom sex was not known. 


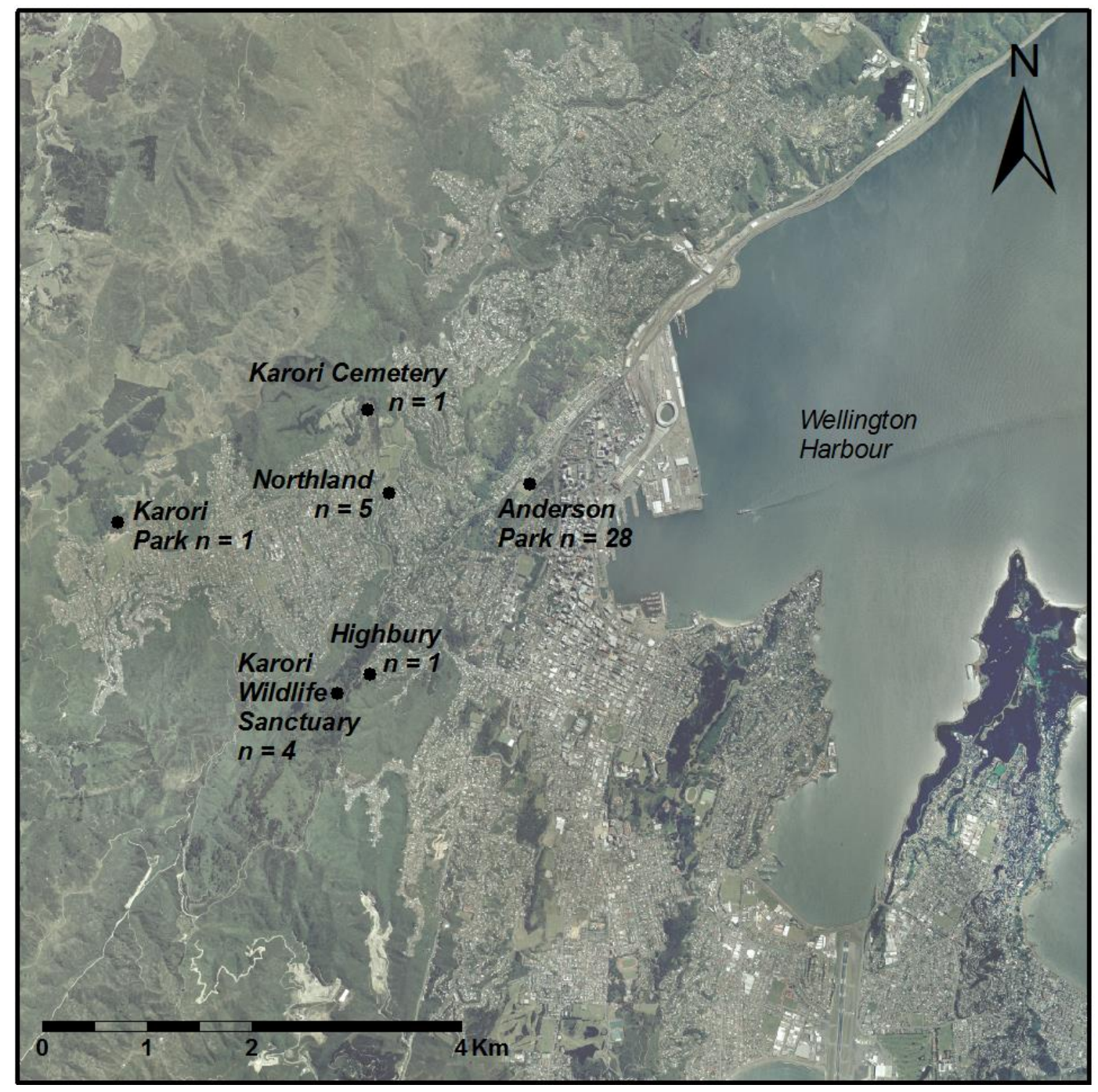

Figure 4.1 Locations of the six sites in Wellington City where kākā were observed sap feeding between November 2011 and November 2012, showing the number of times sap feeding was observed at the site. 


\subsection{Results}

\subsubsection{Observations of kākā behaviour}

Behaviour sampling took place in Anderson Park, Wellington Botanic Garden (Figure 4.1), for 25 60-100 minute periods resulting in 15 observation periods in which kākā were sampled for between 4 and 95 minutes. Systematic observations ceased after 25 observation days as no kākā were observed in the area on the final six observation days. Kākā were observed for a total of 804 minutes out of a total potential observation time of 1850 minutes.

The ethogram comprised nine behavioural categories, including three types of foraging, two categories of locomotion, playing, resting and social behaviours (Table 4.1).

All individuals identified during behavioural sampling were juveniles (fledged in $2011 / 12$ season, $n=18$ ) or fledged in the preceding season $(2010 / 11, n=10)$. The remaining observations were of unidentified or unbanded birds.

Kākā spent the majority of time foraging (Figure 4.2). Between 0 and $89 \%$ of foraging observations during an observation period were of the preferentially sampled sap feeding. Foraging for flowers and nectar comprised $22 \%$ of observation time and $15 \%$ of observation time was of foraging for seeds and cones. The remaining behaviour categories were less common; social interaction, resting/preening, climbing and walking, flying, and chewing in a non-foraging context comprised less than $10 \%$ of observation time each.

The percentage of time spent engaged in different activities differed between birds that fledged in the 2010/11 season and juveniles $\left(\chi_{4}^{2}=49.3, p<0.001\right)$. Juveniles spent more time foraging on flowers and seeds and more time playing than did birds that fledged in the $2010 / 11$ season (Figure 4.3). Birds that fledged in 2010/11 were observed spending a greater proportion of time foraging and feeding on sap ( $58 \%$ of observation time) than juveniles (26\%). 
Table 4.1 Ethogram of kākā behaviour, developed from observations of kākā in trees at Wellington Botanic Garden from June to August 2012.

\begin{tabular}{|c|c|}
\hline Behaviour & Description \\
\hline Foraging for sap & $\begin{array}{l}\text { Comprised stripping and/or prising bark from a tree } \\
\text { trunk or branch and using the tongue to lick sap from } \\
\text { exposed cambium or the under surface of removed } \\
\text { bark pieces. Prising and lapping were often } \\
\text { indistinguishable. }\end{array}$ \\
\hline $\begin{array}{l}\text { Foraging on } \\
\text { flowers/nectar }\end{array}$ & Manipulating and consuming nectar or whole flowers. \\
\hline $\begin{array}{l}\text { Foraging on } \\
\text { seeds/cones }\end{array}$ & Manipulating and consuming seeds, nuts and cones. \\
\hline Chewing other & $\begin{array}{l}\text { Using the beak to manipulate an object in a non- } \\
\text { foraging context. Included chewing and/or snapping } \\
\text { off twigs and chewing anthropogenic objects such as } \\
\text { wire. }\end{array}$ \\
\hline Playing & $\begin{array}{l}\text { Common play behaviours included swinging or } \\
\text { hanging upside down, often accompanied by wing } \\
\text { flapping and grasping the branch by one leg. Included } \\
\text { bite, wing flap, hang, and bill lock behaviour } \\
\text { categories of Diamond and Bond (2004). }\end{array}$ \\
\hline Climbing/walking & $\begin{array}{l}\text { Moving around a tree. Included walking, sidling and } \\
\text { using the bill to assist movement usually while } \\
\text { moving up or down the trunk. }\end{array}$ \\
\hline Flying & $\begin{array}{l}\text { Flying from a tree ended the observation period. } \\
\text { Occasionally birds would move around within a tree } \\
\text { by flying, this was usually when threatened by a } \\
\text { conspecific. }\end{array}$ \\
\hline Resting/Preening & $\begin{array}{l}\text { Generally perching immobile but included } \\
\text { movements such as wing or leg stretches or self- } \\
\text { preening. }\end{array}$ \\
\hline Conspecific interaction & $\begin{array}{l}\text { All non-play social behaviours between conspecifics. } \\
\text { This included beak touching, allo-preening, agonistic } \\
\text { behaviours and attempted mating. }\end{array}$ \\
\hline
\end{tabular}




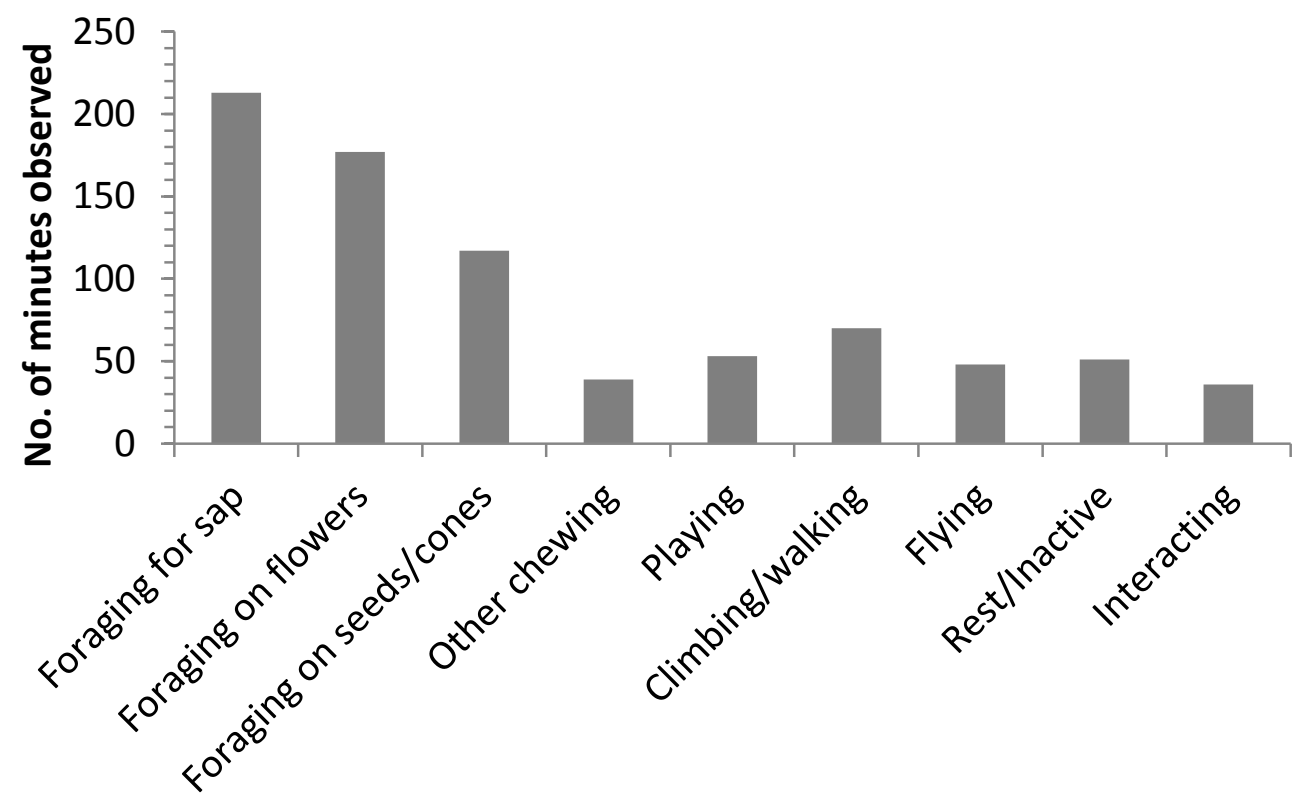

Figure 4.2 Number of minutes of each behaviour category observed during a total of 804 minutes of kākā observation over 25 days at Anderson Park, between mid-August and late-September 2012.

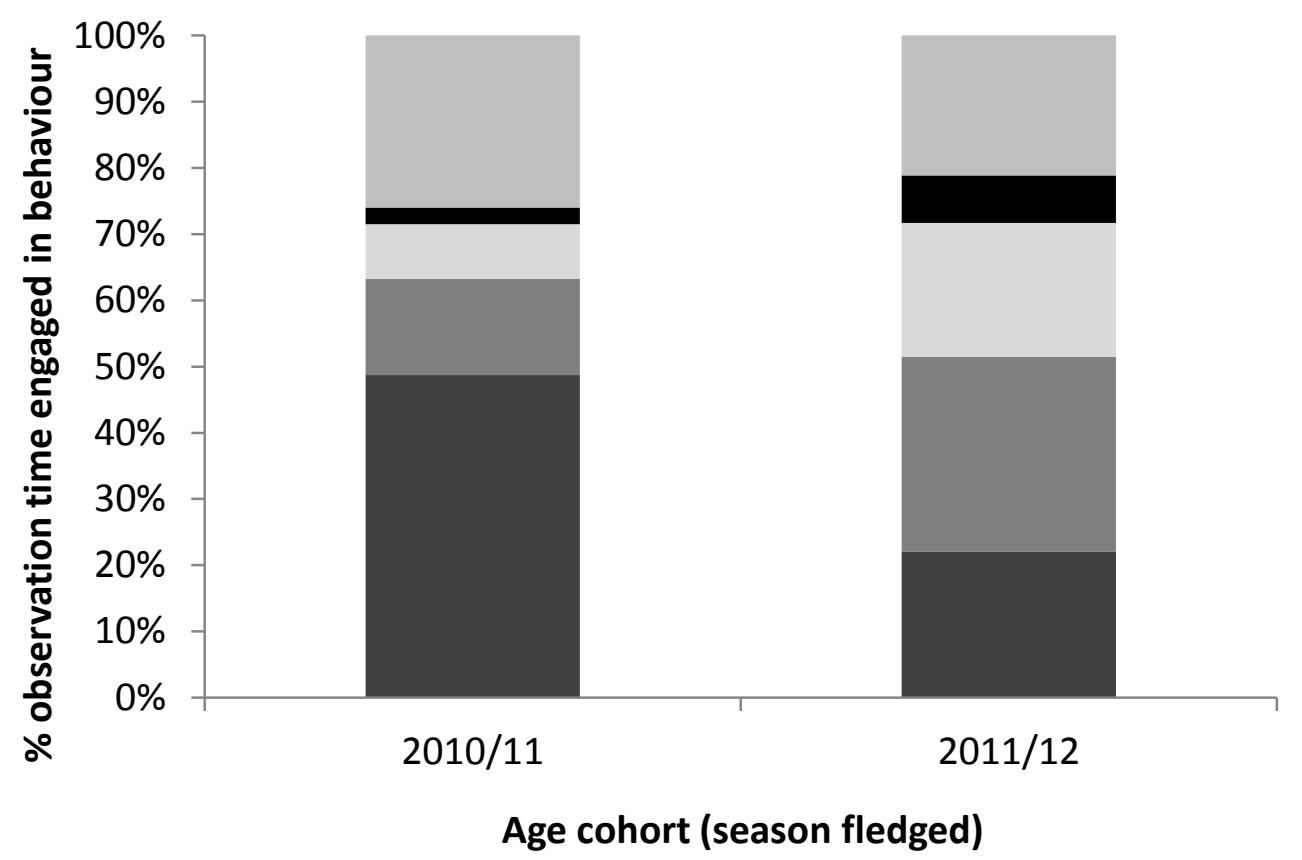

Other $\square$ Play $\backsim$ Foraging on seeds $\square$ Foraging on flowers $\square$ Sap foraging

Figure 4.3 Percentage of observation time spent by kākā on different behaviours by kākā that fledged in the 2010/11 season (total observation time: 158 mins) and 2011/12 season (total observation time: 336 mins). 


\subsubsection{Observations of kākā sap feeding behaviour}

Over the course of the study 40 observations of sap feeding were made and 20 individual kākā were identified foraging for sap (Table 4.2). The majority of individuals were observed sap feeding once, however three individuals were observed twice and one observed on six separate occasions. Unbanded kākā were observed sap feeding on eight occasions and birds were unable to be identified during four observations of sap feeding. A total of 547 minutes of sap feeding were observed over the course of the study.

Sap feeding was observed on 28 occasions at the Wellington Botanic Garden, all during systematic behavioural sampling (Section 4.3.1). Seventeen of these observations were of 13 different individual kākā, the remaining observations were of unbanded or unidentified kākā. Observations of sap feeding were made at Karori Cemetery (Figure 4.1, 1 observation), Karori Park (1), KWS (4) and in the suburb of Highbury (1). Five observations, of two individual kākā, were made on a single Lawson cypress (Chamaecyparis lawsoniana) tree on private property in the suburb of Northland. All observations of sap feeding at Wellington Botanic Garden were on Eucalyptus leucoxylon. Elsewhere in Wellington, sap feeding was observed on macrocarpa (Cupressus macrocarpa), Lawson cypress, Himalayan cedar (Cedrus deodara) and mahoe (Melicytus ramiflorus).

Two types of tree damage have been observed in Wellington; transverse gouges and removed patches of bark. Both adult and juvenile kākā were observed engaging in both types of bark damage and bark removal behaviour differed between the two types of damage. Transverse gouges were made by using the beak to prise a deep gouge through the bark layer. The lower mandible was hooked under the bark and prised away from the bird, with the upper mandible held against the outer side of the bark to assist with leverage. This resulted in the bark gouge being extended away from the bird. Lapping sap and deepening or lengthening the gouge could not be distinguished as they occurred simultaneously. A sap foraging kākā would move between multiple gouges 
regularly during a sap feeding bout, spending between 1 second and 2.5 minutes at a single gouge ( $\bar{x} \pm \mathrm{SD}, 45 \pm 43$ seconds, $\mathrm{n}=21$ ) before moving to another one nearby. Up to six bark gouges were utilised during a single sap feeding bout.

The other type of tree damage was characterised by the removal of patches of bark from a trunk or branch. The sap feeding bird would begin by prising off small pieces of bark until the cambial layer was reached. The mandible was then used to lever off small pieces of bark from around the edge of the bark wound, gradually enlarging its size. Bark was removed using the same technique as for horizontal gouges, with the upper mandible providing leverage and the lower mandible hooking under the bark and levering away from the bird. Removed pieces of bark were dropped to the ground often with a flicking motion of the head and the ground beneath recently damaged trees was often littered with bark pieces. At these types of bark wounds, a kākā would usually forage from only one or a few patches, alternating between enlarging the patch and lapping sap from edges that had previously been exposed. During this type of bark removal, lapping of sap could often be observed directly, particularly when large areas of cambium had been exposed. This occurred by the kākā holding its bill open and using the tongue to lick the exposed cambial surface, predominantly at the edges of the removed bark. The bird would also sometimes tilt its head and run the side of its bill over the exposed cambial surface lapping sap that had exuded. Sap was also often licked from the underside of a piece of bark immediately after it was removed from the tree.

Despite their strong beak, removing bark took considerable time and effort. When initiating a bark wound a kākā may test various points on the bark, presumably to find a weak spot such as a knot or ridge in the bark. Once the kākā had a firm grasp under the bark, it would lever the bark off. The head and neck would be used to lever off thinner bark but for thicker barked trees, a kākā would use its entire body as leverage. Sometimes a kākā would move around to 
find an improved foothold to increase leverage. The sap feeding bird may stand on a lateral branch but often clung to the trunk in any orientation.

The number of minutes spent sap feeding in a single bout ranged from less than 1 minute to 52 minutes, with a mean of $13.7 \pm 12.5$ minutes. Kākā were already engaged in sap foraging when sampling began in $33 \%(n=13)$ of observations so bout length is likely to be underestimated.

Sap feeding was observed on trees with many hundreds of scars and also on trees with no previous damage. Kākā returned to individual sap feeding trees repeatedly on multiple days for at least three weeks. Multiple observations of the removal of bark patches on three trees at two sites suggest that kākā may remove bark patches vertically down a tree trunk. Over the course of two to three weeks, new patches were observed to be removed beneath those already present or current patches were extended downward. No patterns were observed in the placement of transverse gouges on a tree.

All bark removal observed during this study was assessed to be for the purpose of sap foraging. Invertebrate feeding was not observed during the study however invertebrates may have been gleaned while removing bark to access sap. 


\subsubsection{Characteristics of sap feeding individuals}

Eight kākā observed sap feeding were identified as juveniles ( $40 \%$ of identified sap feeding kākā), having fledged in the 2011/2012 breeding season. Seven kākā fledged in 2010/2011, three in 2008/2009, and one each in 2007/2008 and 2004/05 (Table 4.2).

Six individuals observed sap feeding were known from previous breeding history to be females (Table 4.2). Behavioural observation of attempted mating during the course of this study suggested that one bird observed sap feeding was male. The sex of one bird is unknown as it was found as a juvenile so nestling measurements were not obtained. The sex of the remaining 12 identified birds was estimated. Six were estimated to be male and six female. Based on individuals whose sex was known or able to be estimated $(n=19$, ie. excluding one banded bird) $63 \%$ of sap feeding birds were female $(n=12)$. This is not significantly more than expected by chance (exact binomial test, $p=0.916$ ).

Sap feeding appears to be a predominantly solitary activity. Of the 40 observations of sap feeding, only four occurred when a conspecific was in the same tree and two with a conspecific within 1 metre of the sap feeder. Vocalisation was rare during sap feeding, compared to frequent calling during other foraging behaviours. Sap feeding bouts were significantly longer when there were no conspecifics present in the area (no conspecifics observed or heard from the observation point, $\left.\mathrm{t}_{12}=-5.34, p<0.001\right)$. The mean length of a sap foraging bout was $28.2 \pm 11.6$ minutes $(n=12)$ when the feeder was alone and $7.4 \pm 6.4$ minutes $(n=28)$ when conspecifics were present in the area.

I recorded eight instances of a kākā displacing a conspecific from a bark wound. This usually occurred simply by the bird approaching the sap feeding kākā who then flew off or moved away. The displaced kākā usually resumed sap feeding at a nearby wound within one minute. I observed one instance of a sap-feeding kākā chasing away a conspecific that landed nearby and two instances where a newly arrived bird unsuccessfully attempted to displace a sap feeding bird from a 
Table 4.2 Number and total duration of behavioural observations of kākā observed foraging for sap in Wellington between November 2011 and November 2012.

Duration of total behavioural observations for unbanded and unidentified kākā comprises the duration of only those observation periods where sap feeding was observed. Note observations of kākā that were never observed feeding for sap are not included.

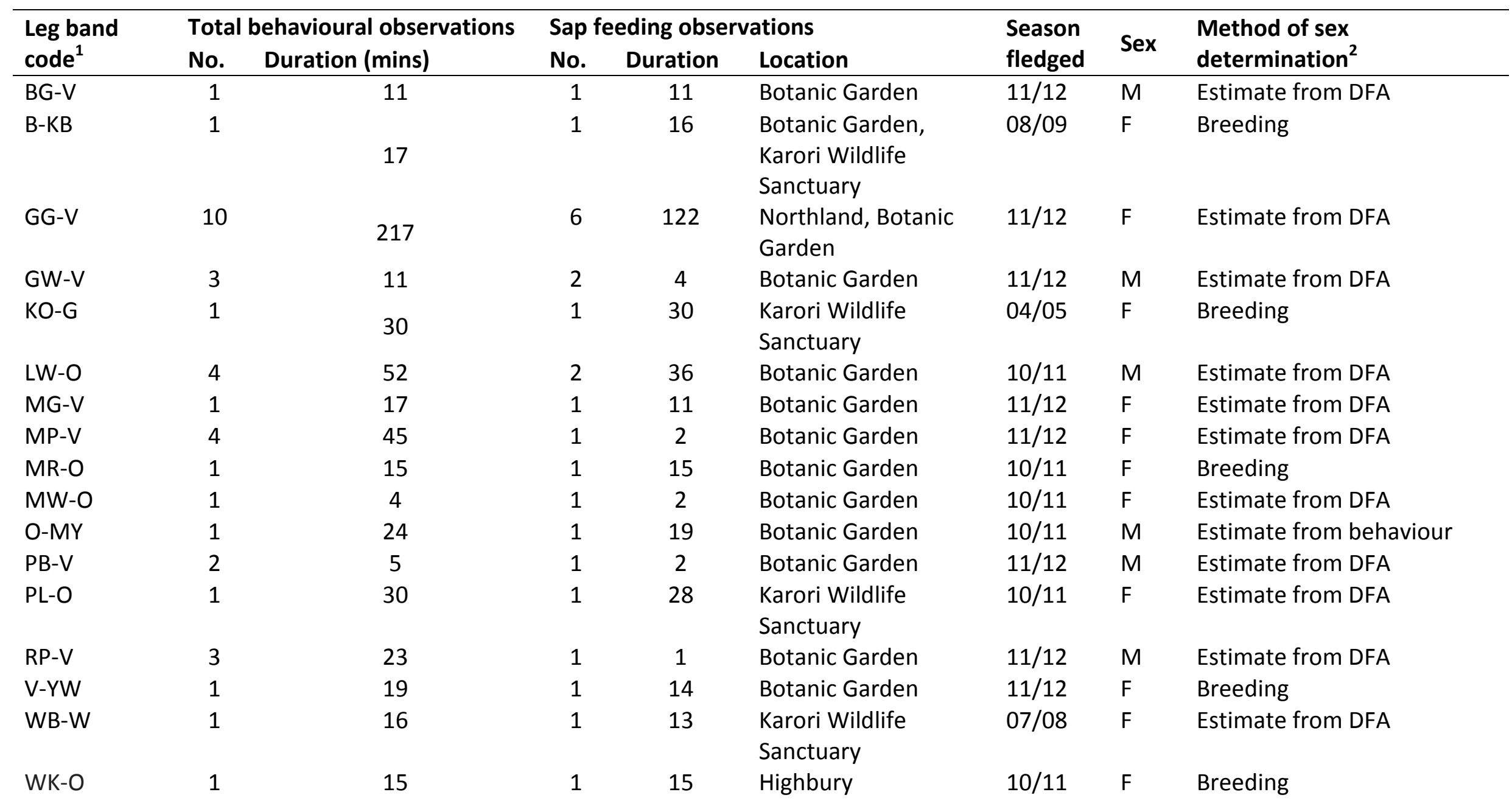




\begin{tabular}{lllllllll} 
W-OO & 2 & 66 & 1 & 52 & Karori Park & $08 / 09$ & F? & Unknown (found as juvenile) \\
YK-O & 2 & 18 & 1 & 5 & Botanic Garden & $10 / 11$ & M & Estimate from DFA \\
Y-RO & 2 & 71 & 2 & 53 & Northland & $08 / 09$ & F & Breeding \\
Unbanded & 8 & 77 & 8 & 62 & $\begin{array}{l}\text { Botanic Garden, } \\
\text { Karori Cemetery }\end{array}$ & & \\
Unidentified & 4 & 53 & 4 & 34 & Botanic Garden & & \\
\hline
\end{tabular}

${ }^{1}$ Codes used by Karori Wildlife Sanctuary to describe coloured leg band combinations. Birds are assigned a unique combination of three coloured bands that are read from bird's left to right, top to bottom. $B=B l u e, G=G r e e n, K=B l a c k, L=L i m e, M=M a u v e, O=O r a n g e, P=P i n k, R=R e d$, $\mathrm{S}=$ Silver, $\mathrm{V}=$ Lavender, $\mathrm{W}=$ White, $\mathrm{Y}=$ Yellow.

${ }^{2}$ The sex of birds without confirmed sex based on breeding or behavioural observation was estimated using a discriminant function analysis based on nestling measurements. 
bark wound. On one occasion I observed a tui (Prosthemadera novaeseelandiae) attempting to access sap while a kākā was foraging at bark wounds on Lawson cypress. The tui approached a recently made bark wound and was chased away by the kākā. After three similar attempts, the tui was able to access a bark wound and fed on sap from the edges of the removed bark for four minutes before being chased away again by the kākā.

Nineteen of the twenty individuals observed sap feeding during this study have been recorded during monthly surveys or by a microchip reader as visiting supplementary feeding stations within KWS in 2012. These birds were recorded feeding from stations between 1 and 1696 times over the course of the year. Two of the females observed feeding on sap bred at monitored nests within Karori Wildlife Sanctuary in the 2012/13 season and an additional two birds bred in both the 2011/12 and 2012/13 seasons.

\subsection{Discussion}

During this study 40 observations of sap feeding were recorded and 20 sap feeding kākā individually identified - a small sample but a considerable increase on previous studies.

Sap feeding was observed in kākā ranging in age from approximately six months old to eight years old. Forty percent of identified sap-feeding birds were juveniles and $75 \%$ were less than 2 years old. Hence it can be concluded that sap feeding is not restricted to adults. Contrary to the suggestion of Berry (1998), the complexity or skills required for either type of sap foraging does not restrict this technique to older birds. Young birds appeared to be competent at removing bark and foraging for sap. Therefore, if sap foraging is a learned behaviour, young kākā are able to quickly master the technique during their first months after fledgling. The high proportion of young birds observed sap feeding may suggest that sap feeding occurs predominantly in younger birds. However, the 
demography of the Wellington population is highly skewed due to recent expansion so this bias more likely reflects the higher proportion of young individuals in the population.

The only individuals of confirmed sex observed sap feeding were females. However, six sap feeding individuals were estimated to be male based on body measurements as fledglings and one individual displayed male mating behaviour. Only one other study has reported a male kākā sap feeding (Beaven 1996) and it has been suggested that sap feeding is predominantly a female behaviour (Beaven 1996; Berry 1998; Greene et al. 2004). The results of this study do not clarify whether males seldom feed on sap or whether the few observations of males in this and previous studies are due to small sample sizes. Future behavioural and breeding observations may enable confirmation of the sex of the birds observed sap feeding during this study. For the moment, however, the results of this study raise the probability that males also sap feed.

The high proportion of juveniles coupled with the observation of estimated males sap feeding suggests that sap is not only a supplementary food for females before breeding, but is important across the lifecycle for both sexes. Although four females were known to breed in the season following observations of sap feeding, two of these birds were observed sap feeding in April and May, at least five months before the onset of breeding.

The majority of birds observed sap feeding during this study (19 of 20 birds) accessed supplementary food at feeding stations within KWS during 2012. Many are also known to visit residential properties where supplementary food is provided, including fruit, seeds, nuts and sugar water (Judi Lapsley Miller, pers. comm.). This suggests that sap feeding is unlikely to be a response to food limitation as sap feeding birds make use of the continual supply of easily accessible food.

It is likely that the two feeding behaviours and resulting bark damage types relate to the nature of the tree bark as they were found on different tree species. 
Bark thickness, hardness and grain would impact on the most efficient way to access the sapwood. In species such as Lawson cypress and Japanese cedar (Cryptomeria japonica) bark is flaky and can be removed in strips. These species showed bark removal in patches. In species where bark did not come off in strips, transverse gouges were seen. These included thicker barked species such as Eucalyptus leucoxylon and very thin barked species such as mahoe.

The observation of tui feeding on sap during this study is the first report of another species feeding on sap from a tree wounded by kākā. Exploiting sap from the bark wounds of other sap feeding species is common and sap availability has been found to have a strong effect on community structure (Chapman et al. 1999). It is possible that other New Zealand bird species may also make use of this resource and sap may provide a valuable resource for birds living sympatrically with kākā. Kākā sap feeding may have other ecological impacts, for example, bats have been observed sheltering in crevices of sap foraging wounds on tōtara (Philip Simpson, pers. comm.)

The availability of supplementary food in Wellington City may impact on kākā behaviour and ecology. Supplementary feeding after release did not appear to alter natural feeding behaviours of kākā at Mt Bruce Reserve (Berry 1998). However the ubiquity of food in the urban landscape may have a greater impact than small-scale supplementary feeding during a soft release in native bush. For example, it is thought that food availability may reduce male provisioning behaviours during breeding in the Wellington population since some nesting females obtain their own food from nearby feeding stations (Judi Lapsley Miller, pers. comm.).

I did not find evidence that kākā that utilised supplementary food fed less on sap. Beaven (1996) and Innes (1994) suggested that provision of a high energy alternative food source may reduce bark damaging behaviours. The majority of sap feeding birds utilised KWS feeding stations and supplementary food provisioning is high among urban residents (see Chapter Five). This suggests that 
sap feeding in Wellington is not a response to energy demand and further provisioning of food is unlikely to curb problems.

Understanding kākā sap feeding behaviour in Wellington City has implications for other cities in New Zealand. Although Wellington is the only city with a resident breeding population of kākā, kākā have been sighted in other cities, including in downtown Auckland (Healy 2012), Hamilton (Neems 2009), Napier and Hastings (Carpinter 2010). These sightings are the result of the expansion of kākā populations near to urban areas assisted by habitat restoration and exotic predator control. Since sap feeding occurs across all life stages and is unlikely to be a pre-breeding behaviour, tree damage resulting from sap feeding may occur in cities that that do not support breeding populations and even those that receive occasional visits from vagrant kākā. Hence, tree damage due to sap feeding is likely to become more common in other cities too. 



\section{Chapter Five: Tolerating, and planting for birds: Avian-human conflict in New Zealand}

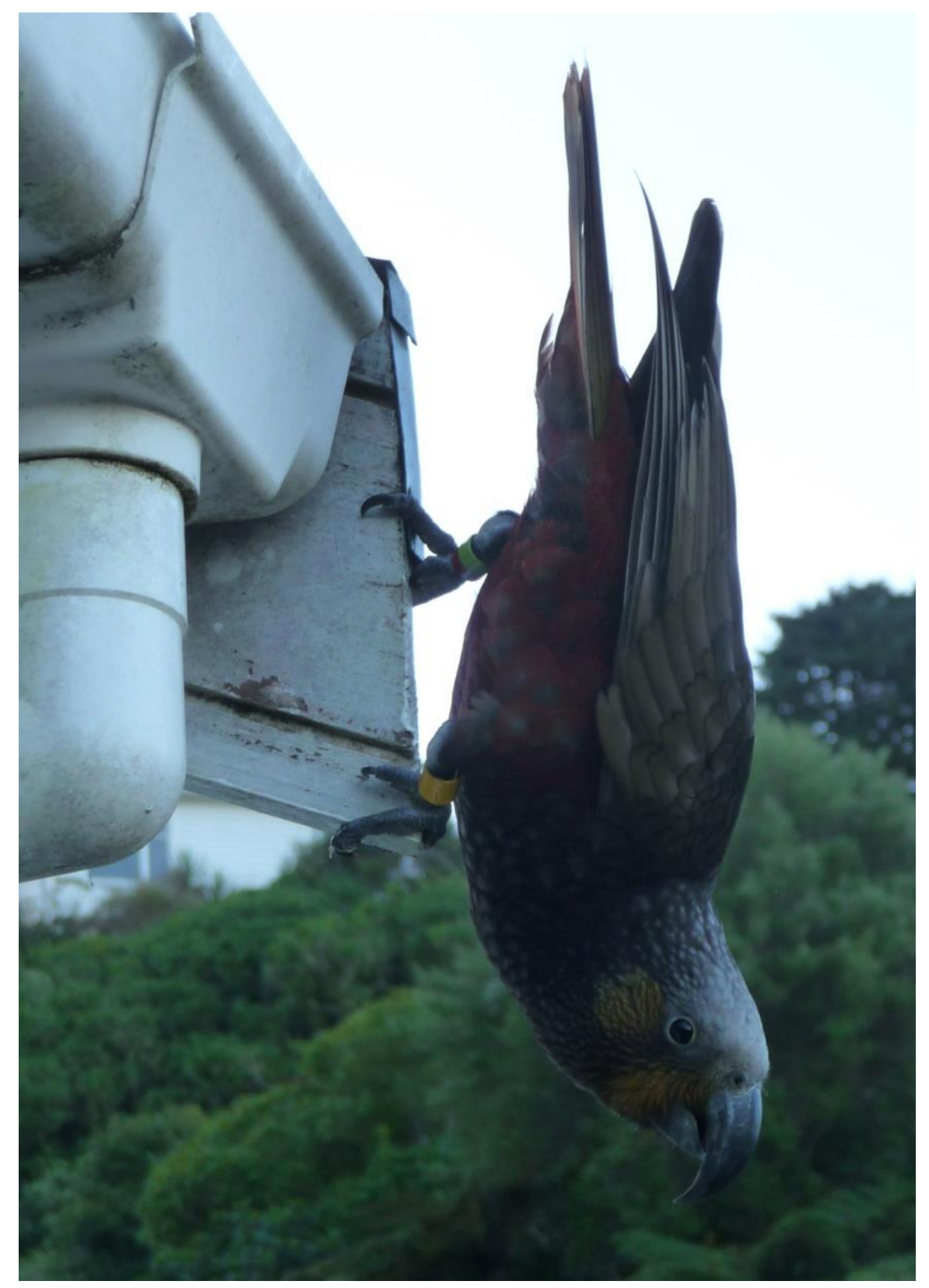

An adult kākā investigating a residential property in the suburb of Highbury, Wellington. 


\section{Abstract}

Human-wildlife conflict is increasing in urban areas worldwide. Since more negative attitudes to wildlife may lead to reduced support for biodiversity conservation, it is important to understand the relationship between urban residents' attitudes to wildlife and their experience of wildlife problems. In Wellington City, New Zealand, North Island kākā (Nestor meridionalis septentrionalis) are causing human-wildlife conflict by damaging trees and property. I conducted a household survey of 1030 Wellington City residents and used an Information-Theoretic approach to multi-model selection and inference to investigate the relationship between residents' biodiversity awareness and engagement with birds and natural areas and their attitude to birds and birdrelated problems. Respondents ( $n=635,61.8 \%$ return rate) had overwhelmingly positive attitudes towards native birds, despite $25 \%$ experiencing a bird problem. Planting trees to attract birds was the only predictor to provide substantial inference for attitude $\left(\omega_{i}=0.873\right)$. Biodiversity awareness, engaging with greenspaces and providing supplementary food for birds provided little explanation for attitude. When I then assessed how experiencing a problem with birds modified these relationships, the confidence model set $\left(\sum \omega_{i} \geq 0.95\right)$ was comprised of the models of planting for birds combined with the additive $\left(\omega_{i}=\right.$ $0.568)$ and interactive $\left(\omega_{i}=0.400\right)$ effects of experiencing a problem. Experience of a bird problem on its own was not found to provide inference for attitude $\left(\Delta \mathrm{AIC}=17.50, \omega_{i}=0.000\right)$. Respondents who had planted for birds were more likely to have positive attitudes even if they had experienced a bird-related problem. Hence attitude to birds and tolerance to problems may be most closely associated with a person's experience and engagement with birds rather than negative experiences. Increasing residents' engagement with birds and encouraging people who provide supplementary food for birds to instead attract them by planting trees and plants may assist in mitigating the growing conflict caused by kākā in Wellington City. 


\subsection{Introduction}

\subsubsection{Human-wildlife conflict}

Human-wildlife conflict is a challenging and widespread issue that threatens the conservation of many wildlife species (Dickman 2010). Traditionally, humanwildlife conflict was seen as a situation where wildlife impacted on human interests, such as when the resource demands of humans and wildlife overlapped (Peterson et al. 2010; White \& Ward 2010). It is increasingly recognised, however, that what may appear as conflict between humans and wildlife may more often be conflict between groups of people with different values, perspectives and objectives for wildlife (Marshall et al. 2007). These disagreements most commonly concern the way wildlife should be managed to address threats to human property, livelihoods, health or safety (Peterson et al. 2010). Hence human-wildlife conflicts represent complex interpersonal conflict that emerges from people's attributions and interpretations of a situation rather than simply resulting from negative interactions with wildlife (Marshall et al. 2007). The intrinsically social nature of human-wildlife conflicts must be addressed in the course of research and management in order for conflict to be effectively resolved (White et al. 2009).

Wildlife conflicts are complex issues, arising from a range of interacting biological, social, cultural, political and economic drivers (Dickman 2010; Young et al. 2010). These drivers include environmental factors, such as land-use and food availability, the behaviour of both people and wildlife, and social factors such as beliefs, values and social inequality (Dickman 2010). These elements mediate the relationship between humans and wildlife and affect the extent and perception of interactions that may lead to conflict. Human-wildlife conflict is an example of a 'wicked' problem; a complex, ill-defined and unstable problem often involving multiple players who may perceive and approach the problem differently (Rittel \& Webber 1973). Wicked problems have no single or optimal solution and partial solutions may generate further, often unforeseen, problems 
or conflicts between those involved (Rittel \& Webber 1973). Each conflict situation has its own locally-specific dynamics due to the unique combination of ecological, social, cultural, and political drivers that contribute to its complexity (Madden 2004; Dickman 2010).

It is increasingly recognised that social as well as ecological research is necessary to inform the understanding and management of human-wildlife conflicts (White et al. 2009). Since conflicts emerge as a result of perceptions and interpretations of a situation (Marshall et al. 2007), it is crucial to understand the social and psychological factors that drive people's perceptions of wildlife and their interactions with them. Conflict levels are seldom proportional to the degree of wildlife impact (Dickman 2010). This can be demonstrated by the fact that many of the most contentious and intractable conflicts globally are focused on carnivores and megaherbivores, despite other species such as invertebrates or rodents causing greater damage (Peterson et al. 2010). In order to understand a conflict, systematic measures of animal damage or impact should be complemented with research into the human dimension of a conflict situation, including the attitudes, values, perceptions and economic vulnerabilities of the stakeholders (Treves et al. 2006).

Since the level of conflict is rarely proportional to the degree of damage or other impact experienced, wildlife conflict is seldom mitigated solely by reducing the impact of wildlife (Dickman 2010). Effective and socially acceptable strategies for conflict management and wildlife conservation need to take into consideration peoples' behaviours, attitudes and perceptions (Dowle \& Deane 2009), hence social research is a vital first step in the management of wildlife conflicts. Understanding how people interact with wildlife may lead to a greater appreciation of the causes and consequences of problems and the potential solutions. For example, human behaviours, such as providing supplementary food or failing to secure refuse, may cause or exacerbate wildlife problems. Once quantified and understood, negative attitudes or behaviours can be targeted for 
change. For example, enhancing people's appreciation for wildlife and the nontangible benefits wildlife provides can change people's perception of a species and may be an effective tool for mitigating conflict by increasing tolerance of wildlife problems (Messmer 2000). The process of social research may also itself help to reduce conflict. By engaging the public and demonstrating that the opinions and experiences of the community are valued, social research may result in greater community ownership of the problem and lead to more effective conflict management (Messmer 2000; White \& Ward 2010).

Understanding the social drivers of conflict is particularly important when wildlife conflicts occur in urban areas. Urban perceptions of wildlife are often based on emotional and symbolic values and, as such, can be highly individualised (Bright et al. 2000; Patterson et al. 2003). Implementing widely accepted yet effective wildlife management strategies becomes increasingly challenging as urban communities diversify, since the diversity of perspectives leads to increased likelihood of conflict over wildlife management. Social science techniques are particularly valuable when understanding a diverse array of stakeholder perspectives (White \& Ward 2010) .

\subsubsection{Attitude}

One of the most common concepts explored in human dimensions of wildlife research is attitude (Manfredo 2008). Attitudes are "an association, in memory, of an evaluation of an object" or action, issue, or event (Fazio et al. 1982; Manfredo \& Dayer 2004). Attitudes can be influenced by beliefs and experiences (Homer \& Kahle 1988), vary depending on the context or situation (Ajzen \& Fishbein 1980) and often change over time (Jonker et al. 2006). A person's attitudes are formed through a variety of factors, including knowledge, beliefs, values, direct experience and cultural norms (Dickman 2010).

Biodiversity awareness, which can include species-specific and ecological knowledge and awareness of biodiversity issues and threats, may be an important predictor of a person's attitude towards wildlife. The value people 
place on wildlife often depends strongly on their knowledge of them (Macdonald \& Service 2007) and higher levels of knowledge about a wildlife species has been linked to more positive attitudes towards that species (Bath \& Buchanan 1989; Kaczensky et al. 2004; Bath et al. 2008). For example, Consorte-McCrea (2011) found that low levels of knowledge about the maned wolf (Chrysocyon brachyurus) were related to decreased positive and increased negative attitudes towards the species. Ecological awareness has also been linked to lower levels of dominionistic, negativistic and utilitarian attitudes towards the environment (Yore \& Boyer 1997). Similarly, an awareness of the rarity of a species and the factors that threaten its survival may lead to more positive attitudes towards a wildlife species (Kellert et al. 1996; Kaczensky et al. 2004; Sillero-Zubiri et al. 2004). Higher levels of wildlife knowledge and awareness may also result in more positive attitudes towards biodiversity conservation more generally (Bath \& Farmer 2000; Sillero-Zubiri et al. 2004; Consorte-McCrea 2011).

Spending time outdoors in parks and gardens may increase a person's connection to nature and result in more positive attitudes towards the environment and wildlife (Dunlap \& Heffernan 1975; Skelly \& Zajicek 1998; Heberlein et al. 2005; Kretser et al. 2009). Given the highly modified nature of urban landscapes, visiting natural areas such as parks and gardens may be an important way for urban residents to experience and engage with nature on a regular basis. In Sweden, greater time spent outdoors by urban residents was associated with more positive attitudes towards wolves (Heberlein et al. 2005). Seeing a species in the wild can result in more positive attitudes towards it and a stronger belief that it needs protection (Consorte-McCrea 2011). Hence, when spending time outdoors presents opportunities to view wildlife, outdoor experience may have a particularly strong impact on a person's attitudes to wildlife.

Direct and active experiences may have a greater impact on attitude than less direct experiences, such as viewing wildlife from a distance (Fazio 1990). Hence 
engaging with wildlife through deliberate activities may be a particularly strong predictor of wildlife attitudes. Taking part in wildlife engagement activities, such as bird watching and providing supplementary food for birds, has been linked to greater interest, affection and concern for nature and wildlife (Tarrant et al. 1997; Yore \& Boyer 1997; Kretser et al. 2009). Bird feeding may be a significant way to connect with nature for urban residents and can lead to a deep and passionate connection between feeders and 'their' birds (Jones 2011). Although selecting plant species to plant in backyard gardens in order to attract wildlife does not appear to have been studied previously, this activity may also allow direct engagement with wildlife and so may be associated with positive attitudes.

Experiencing negative interactions with wildlife may have a particularly strong impact on attitude, resulting in more negative attitudes towards the species at fault (Nyhus \& Sumianto 2000; Riley \& Decker 2000; Naughton-Treves et al. 2003; Bagchi \& Mishra 2006; Jonker et al. 2006). For example, attitudes of Massachusetts residents towards beaver were closely related to the level of beaver damage they had experienced in the past (Jonker et al. 2006). Negative interactions with other urban species, such as white-tailed deer (Odocoileus virginianus) and prairie dog (Cynomys spp.), have also been linked to more negative attitudes (Zinn \& Andelt 1999; West \& Parkhurst 2002). Hence, conflict with wildlife can result in more negative attitudes to wildlife species. Negative experiences may also impact on the way future wildlife interactions are perceived. One study found that previous experience of wildlife damage resulted in less positive perceptions of future interactions with wildlife (Kretser et al. 2009).

Factors influencing attitude are likely to be interrelated and may mediate and moderate each other and their relationship with attitude. Since factors such as biodiversity awareness and outdoor experience influence a person's attitude to wildlife these factors are also likely to influence perceptions of human-wildlife 
conflict. A US study found that people who engaged in non-consumptive wildlife activities (such as bird watching) were half as likely to report a negative wildlife interaction (Kretser et al. 2009).

\subsubsection{The importance of attitude}

The majority of the world's population lives in cities, and New Zealand is one of the most urbanised countries in the world with $86 \%$ of its population living in urban areas and nearly $72 \%$ in the 16 largest urban centres (Statistics New Zealand 2006b). Managing urban wildlife conflicts is important to allow urban residents to maintain a positive connection with the natural world. Positive experiences in the natural world are vital to ensure people continue to value nature, yet opportunities to experience and meaningfully connect with nature in urban environments are limited (Dunn et al. 2006). Seeing wildlife in urban neighbourhoods has been linked to increased feelings of connection to nature (Lischka et al. 2008) and even maligned species such as feral pigeons may play an important role in fostering this (Dunn et al. 2006). Hence it is important to understand how people interact with wildlife in the urban environment and the impact that negative interactions may have on attitudes towards wildlife.

One of the central reasons for focusing on people's attitudes is their link with behaviour. Although attitudes alone do not necessarily predict behaviour (McCleery et al. 2006), in conjunction with beliefs, norms and perceptions of behavioural control, attitudes are an important precursor of behavioural intentions (Ajzen 1991). Specific behaviours result from behavioural intentions mediated by situational factors such as economic constraints, social norms and opportunities for choice (Hines et al. 1987). The relationship is bidirectional, since attitudes can also be the result of behaviour (Manfredo 2008). Therefore, understanding attitudes towards wildlife and wildlife interactions is a key part of the management of human-wildlife conflicts (Jonker et al. 2006).

The attitudes of urban residents towards wildlife may have important implications for biodiversity conservation and environmental stewardship, both 
within and beyond cities. People with a positive attitude towards wildlife tend to provide greater support for conservation (Kaczensky et al. 2004; Kretser et al. 2009). For example, a cross-cultural study found that positive attitudes towards wildlife were linked to greater support for policies such as stricter environmental regulation, establishing national parks and providing tax incentives for voluntary habitat protection (Rauwald \& Moore 2002). The urban landscape can provide valuable habitat for threatened species (Lawson et al. 2008; Pennington et al. 2008) and community-driven conservation is particularly important in humandominated landscapes (Miller \& Hobbs 2002). Furthermore, with increasing numbers of people living in urban areas, support for conservation in landscapes outside cities will also need to come from urban residents (Miller 2005; Dunn et al. 2006). Therefore, reducing negative interactions between wildlife and humans in urban areas may be crucial for maintaining support for biodiversity conservation, in both urban and non-urban landscapes.

Fostering positive attitudes toward wildlife may also be important for proenvironmental behaviour more generally. A person's attitude towards wildlife may closely reflect their attitudes and relationship with nature (Kellert 1983) and interest and affinity for nature can be a powerful predictor for proenvironmental behaviour (Kals et al. 1999). Hence, experiences with and attitudes towards urban wildlife may play a crucial role in fostering attitudes and behaviours that benefit the environment in urban residents.

\subsubsection{Human dimensions of wildlife in New Zealand}

There has been little research conducted in New Zealand regarding people's interactions with, or attitudes towards, wildlife. The only known studies in New Zealand have explored people's attitudes in the context of conflict with an introduced synurbic bird species, the feral pigeon (Columba livia, Krimowa 2011; Ryan 2011). These studies found predominantly negative attitudes towards the species from local residents and business owners. Engagement with birds was the leading predictor of attitude, with those providing food or water for any 
species of bird having a more positive attitude towards pigeons (Ryan 2011). Greenspace visitation where pigeons are common (Ryan 2011) and frequency of seeing the species (Krimowa 2011) were found to be associated with more negative attitudes towards pigeons. Interacting with wildlife can have positive or negative effects on a person's attitudes to a species depending on their evaluation of the experience and their perceptions of the species. Exotic pests, like feral pigeon, may be perceived differently to native species (Jones \& Thomas 1998), hence predictors of attitude may vary between common synurbic species and natives.

The native kea (Nestor notabilis), a close relative of the kākā found only in alpine habitats, is infamous for causing problems in ski-field carparks, mountain huts and alpine towns where they engage in destructive behaviour particularly when attracted by food waste (Peat 1995). Although studies have recommended human behaviour change, such as improved waste disposal practices, to reduce conflict (Brejaart 1994), the social aspects of the problem have not been a focus of research. Kea also sometimes injure and kill sheep on high country farms by attacking them (Scott 2012). Research into this problem, including the social aspects of the conflict, is currently underway (Clio Reid, pers. comm.).

The ecological awareness and environmental behaviours of urban residents, factors that may be associated with wildlife attitude, have been quantified in a previous study based in Wellington City (Parker 2009). Parker (2009) found high levels of engagement with wildlife, such as feeding (42\%) and planting for birds (37\%), and demonstrated a positive relationship between greenspace visitation and ecological awareness.

\subsubsection{Human dimensions of conflict with kākā}

North Island kākā (Nestor meridionalis septentrionalis: Nestoridae) were reintroduced to Wellington City in 2002 (Miskelly et al. 2005) and subsequent breeding success has led to a current population estimate of 180-250 birds (Karori Sanctuary Trust, unpubl. data). 
Kākā strip bark from trees to feed on sap, leaving characteristic bark damage (Charles 2012). Bark damage has been observed on trees in Wellington City Council parks and reserves and on private land in many suburbs throughout the city (see Chapter Three). The tree damage caused by kākā in Wellington City is a concern for a number of reasons. Bark removal compromises the structural integrity of the tree, increases the risk of branch fall, induces epicormic growth and may result in foliage dieback and even death of the tree. Damaged trees are a significant hazard and tree removal is costly. Trees with considerable amenity and heritage value are being lost.

Other behaviours of kākā have also been the subject of complaints from Wellington City residents. Kākā cause minor damage to masonry, timber joinery and cladding (Charles 2012) and may eat fruit and nuts from residents' trees (Chug 2010). Their loud calls, particularly in the early morning, have also induced complaint from Wellington residents (pers. obs.).

The impact that experiencing property damage from kākā may have on people's attitude and behaviour toward kākā, as well as how it may impact their support for wildlife conservation, is unknown. Ensuring public support is particularly vital for private conservation organisations, such as the Karori Sanctuary Trust, that rely on financial, political and voluntary support from the local community.

\subsubsection{Aims}

This study had two main aims. First, to understand the nature and extent of bird problems experienced by residents of Wellington City, with a particular focus on those caused by kākā. This will give a relative measure of current and potential bird conflicts in Wellington City and will provide a baseline from which to measure future changes.

The second aim of this study was to investigate the relationship between residents' attitude to birds and their biodiversity awareness and engagement with birds and natural areas. I then assessed how experiencing a bird problem modified these relationships. 
With continued conservation success, conflicts between people and bird species may increase in New Zealand (see Chapter Six) and it is important to understand the possible social impacts of conflict. This study will provide insight into the impact that experiencing bird problems may have on people's attitudes towards birds, and may lead to recommendations for minimising the social impact of kākā damage in Wellington City. This will be the first reported study considering people's attitudes toward native bird species in New Zealand and will provide a valuable comparison to research in other countries.

\subsection{Method}

\subsubsection{Study area}

This study was carried out in inner city residential suburbs of Wellington City, New Zealand $\left(41.28^{\circ} \mathrm{S}, 174.77^{\circ} \mathrm{E}\right)$. A description of Wellington City and the general characteristics of its population was provided in the introduction to this thesis. The nine suburbs included in this study were Aro Valley, Brooklyn, Highbury, Karori, Kelburn, Northland, Vogeltown, Wadestown and Wilton.

\subsubsection{Questionnaire development}

The questionnaire was designed to quantify residents' attitudes to urban avifauna and related damage and to investigate factors that may lead to these attitudes. It also gathered information about the bird problems experienced by respondents and any actions taken to mitigate problems (see Appendix III for the questionnaire). This study focused on people's attitudes and experiences with wild birds and was not restricted to kākā. This broad taxonomic focus was chosen for a number of reasons. Tree damage may be relatively rare and localised in Wellington and therefore few residents may currently be experiencing problems or may not attribute damage to kākā. By collecting information about all types of bird problems I was able to assess the relative severity of problems caused by kākā, and this could be used to assess how the problem has increased if this 
survey was to be repeated in the future. I also wanted to avoid inadvertently increasing conflict by making people aware of an issue that they would otherwise not have been concerned about.

In order to inform the development of the questionnaire, I visited and talked to Wellington City residents who contacted me in response to a request published in a local newspaper (The Dominion Post, 6 March 2012) and on relevant websites, emailing lists and social media for reports of kākā sightings or problems (see Chapter Three).

Attitude was quantified by asking four questions about a person's attitude to birds, two questions about the person's tolerance and attitude towards problems and two questions about the person's attitude towards management of overabundant or problem-causing birds. These questions were adapted from previous studies of wildlife attitudes in the context of human-wildlife conflict in other countries (Jonker et al. 2006; Hill et al. 2007; König 2008; Carlos et al. 2009; Dowle \& Deane 2009). In selecting and adapting questions I sought to balance questions that were dissimilar enough to capture the salient dimensions of wildlife attitude with questions that were redundant enough to achieve internal consistency between items. Responses were given on a 5-point Likert scale where 1 signified strong agreement and 5 strong disagreement.

Four factors hypothesised to influence attitude towards wildlife were measured, biodiversity awareness, engagement with natural areas and two types of engagement with birds. In order to assess engagement with birds, respondents were asked if they put food or water out for birds and if they have planted trees or plants on their property in order to encourage birdlife. Biodiversity awareness was measured by combining two questions. The first question asked respondents to identify colour photographs of eight birds; four native and four introduced species, with a mixture of commonly known and rare species. Scientific or common names to at least family level were accepted (e.g. gull was assessed as correct for Larus dominicanus) and one point was awarded for each correct 
answer. The second question asked respondents to list the three greatest threats to native plants and animals in New Zealand. These were determined from consensus of the scientific literature to be habitat loss and fragmentation, invasive species, and over-exploitation (Dopson et al. 1999; Craig et al. 2000; Clout 2001; Walker et al. 2006; Kingsford et al. 2009; Kelly \& Sullivan 2010). Responses were categorised and one point was given for each threat correctly identified. Frequency of visits to public greenspace (defined as parks, reserves or public gardens) was used as a measure of a respondent's engagement with natural areas. Respondents were asked how often in the past year they visited greenspaces on a 5-point scale ranging from not at all to 2-3 times per week.

Respondents were asked if native or introduced birds cause any problems on their property and were asked to rate the problems' severity on a 4-point scale ranging from minor through to very severe. Since respondents were asked to self-evaluate their experience of problems, this measure incorporated the level of the problem (e.g. damage) as well as the respondent's evaluation of it. Respondents were asked to list the problems and the species they thought caused them. They were also asked if any actions had been taken to mitigate bird problems and for their estimated cost. Lastly, information on respondents' sex, age, highest educational level, income and ethnicity was collected in a similar format to New Zealand's 4-yearly government population census.

The questionnaire was piloted with 12 tertiary students to ensure statements and scales were clear and relevant, and the suggestions of pilot participants were used to improve the questionnaire.

\subsubsection{Survey distribution}

Questionnaires were hand-delivered to 1030 households in Wellington city. A preparatory letter, advising that a questionnaire would soon be delivered, was followed 7-8 days later by the delivery of a questionnaire, explanatory letter and postage-paid return envelope (Appendix III). A letter reminding people to 
complete the survey and thanking them for their contribution was delivered one week later.

Residents were also given the option of completing the survey online. The online version was identical to the hard-copy questionnaire and was developed on Survey Monkey (www.surveymonkey.com). Instructions for accessing the online survey were provided in the explanatory and reminder letter.

One thousand questionnaires were distributed to a stratified random selection of households in Wellington City. Fifty questionnaires were delivered at two randomly selected distribution sites within each of 9 suburbs. These suburbs were chosen as they are situated within the kākā extent zone developed in Chapter Three (Figure 3.1). These suburbs were Wadestown, Wilton, Northland, Kelburn, Karori (split into Karori East, and Karori West due to its large size), Highbury, Aro Valley, Brooklyn and Vogeltown (Figure 5.1). Suburbs falling within the kākā distribution zone but having large areas of high density housing were excluded. These were the suburbs of Newtown, Mt Cook and Thorndon.

Additionally, surveys were delivered to the 30 residents that reported a kākā sighting or kākā damage and gave permission for a questionnaire to be sent to their address. Minor formatting changes were made to these questionnaires so that they could be distinguished from those distributed randomly. Responses from these residents were included in the description of bird problems, but were excluded from subsequent modelling analyses.

Due to the survey distribution method and anonymous nature of the surveys, non-respondents were not able to be re-sampled or evaluated to determine if they differed from respondents. 


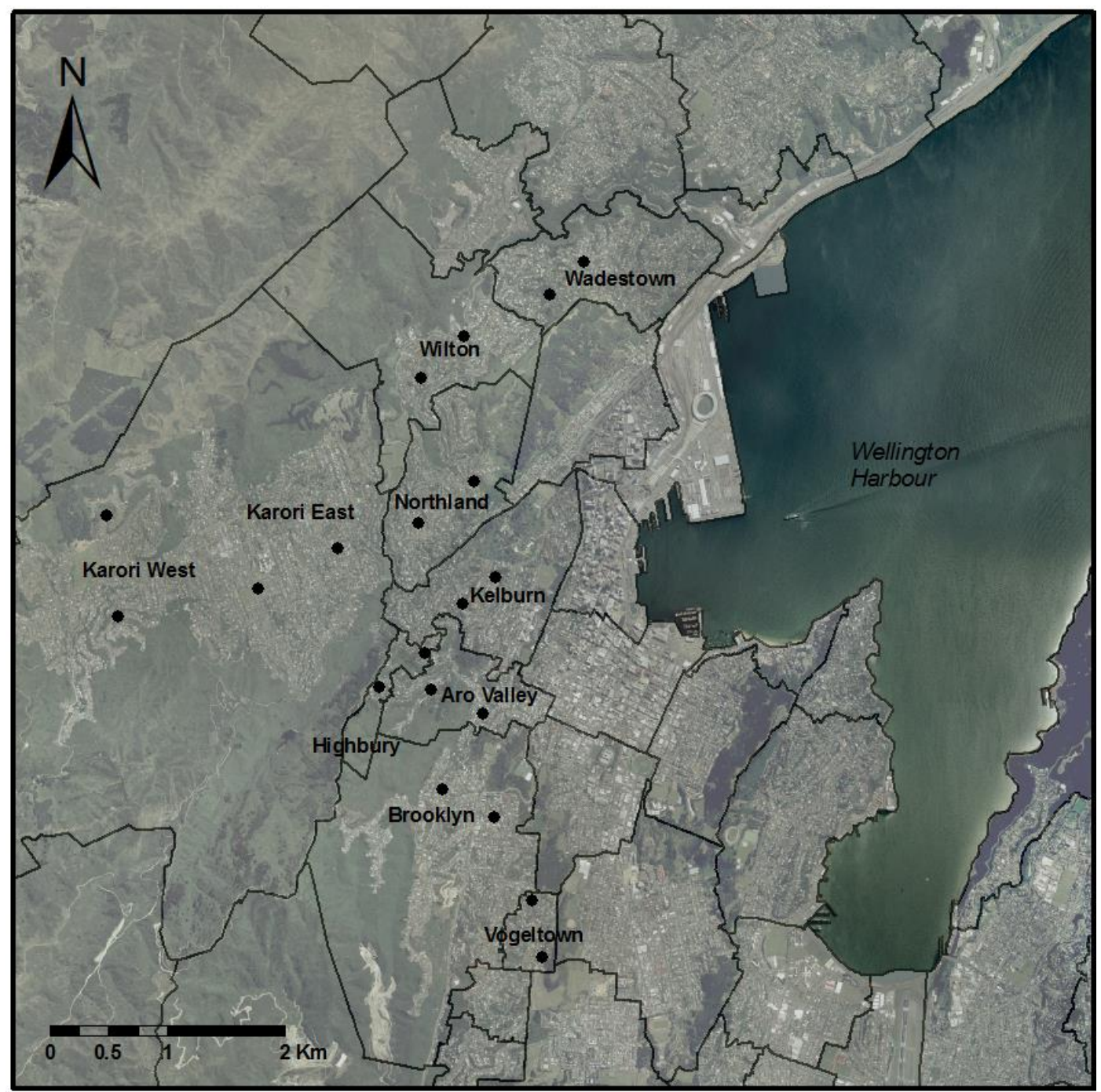

Figure 5.1 Household survey delivery locations, showing the two randomly determined start points for survey delivery (black dots) within each of the nine suburbs surveyed. The suburb of Karori was spilt into Karori East and Karori West due to its large size. 


\subsubsection{Statistical analysis}

\section{Data preparation and construct development}

The demography of survey respondents was compared to the demography of the population in the 9 suburbs included in the study. Age, sex, ethnicity, education and income data for relevant suburbs were obtained from the 2006 New Zealand Census (Statistics New Zealand 2006a) and compared to that of respondents using chi-squared tests.

Attitude and prevalence of bird problems were compared between the respondents from the randomly selected sample and those who had previously reported a kākā sighting or damage using the Fisher's exact test and Student's ttest.

A missing values analysis was conducted using SPSS (SPSS Statistics for Windows, Version 19.0) to assess the extent and pattern of missing values in the dataset. Respondents who failed to complete more than one question were not included in further analyses after comparison with the remaining dataset. Where one value (personal income in all cases) was missing for a respondent, missing data was imputed using the expectation-maximisation (EM) algorithm by treating income as a quantitative variable. Imputed data was recoded to an ordinal variable by rounding values to the nearest whole number.

The distribution of independent variables was assessed using plots and tests of skewness and kurtosis. Collinearity between independent variables was examined using Spearman's rho, rank biserial correlation coefficients and phi coefficients as appropriate for ordinal-ordinal, ordinal-dichotomous and dichotomous-dichotomous associations (Appendix I, Table Al.2). Collinearity between independent variables and demographic variables was assessed to determine whether the inclusion of demographic variables in models of attitude was warranted (Appendix I, Table Al.3). As attitude questions 7 and 8 were 
negatively phrased, response scores for these questions were inverted so that for all questions low values represented positive attitudes to birds. Principle component analysis was used to assess the validity of combining bird species identification score and environmental threat score into one variable, biodiversity awareness.

An exploratory factor analysis (EFA) was undertaken to explore the underlying structure of the eight attitude items. The dataset was split in half and exploratory analyses were run on a random sample of 289 respondents. Splitting the sample in this way enabled the factor structures identified in the exploratory analysis to be tested with a different sample in subsequent model analysis. Principal axis factoring was used as the extraction method as it does not require normally distributed data and oblique rotation of the factor loadings was chosen as variables are correlated. Factors with an Eigenvalue over 1 were retained.

\section{Structural equation modelling}

I attempted to use structural equation modelling (SEM) to construct models and compare hypotheses about factors that lead to attitude towards birds. SEM is a multivariate statistical method that encompasses factor and path analysis and is commonly used in social sciences and psychology (Kline 2005). This technique can be used to represent and test variables that cannot be directly measured, through the development of latent constructs using multiple indicator (observed) variables. It can also be used to explore indirect effects between variables, such as mediation or moderation by an intermediary variable (Kline 2005; Arhonditsis et al. 2006).

In order to develop a latent construct of attitude towards birds, a confirmatory factor analysis (CFA) was conducted in AMOS (IBM SPSS AMOS Version 19) using the subset of cases not used in the exploratory analysis. A single factor CFA model was constructed to test the loading of the six items identified by the EFA as forming the single factor labelled wildlife attitude. Due to non-normal distribution, bootstrapping was used to obtain a mean chi-squared value and 
Bollen-Stine p-value (Kline 2005; Ballantyne et al. 2011). I failed to find support for the measurement model. Structural equation modelling is not robust to departures from normality (Kline 2005) and the lack of support is probably due to extreme positive skew in the dependant variables. Extreme skew in individual attitude variables prevented the parcelling of variables to improve normality (Kline 2005). Thus, I adopted a simpler generalised linear modelling approach to model fitting in a multi-model selection and inference framework.

\section{Generalised linear modelling}

Summing the scores of the six attitude questions resulted in a highly skewed variable (skewness: 2.16, kurtosis: 7.36 ) due to the high proportion of respondents agreeing or strongly agreeing with all six attitude questions. The low proportion of respondents expressing a neutral or negative attitude to birds ( $n=$ $158,27 \%$ ) led to my interest in what generates these non-positive attitudes. Therefore attitude was modelled as a dichotomous variable to investigate differences between respondents with wholly positive attitudes towards birds and respondents with neutral or negative attitudes. Respondents who provided a positive score (scoring 1 or 2 on Likert scale) for the six attitude questions identified in the EFA as forming one factor were coded as having a positive attitude. Cases in which one or more attitude questions were scored neutral or negative (3-5 on Likert scale) were coded as non-positive. The binary response variable was modelled as a generalized linear function with a binomial error distribution and a logit-link function using the statistical package $R$ (Version 2.15.2, The R Foundation for Statistical Computing 2012).

I adopted an Information-Theoretic approach to multi-model selection and inference. This approach is superior to traditional null-hypothesis testing and allows multiple competing hypotheses to be compared evidentially (Johnson \& Omland 2004). To evaluate relationships between attitude and the variables of interest, two candidate sets of generalised linear models were fitted. Firstly, a set of candidate models was constructed using the four potential predictors of attitude; biodiversity awareness, greenspace visitation, feeding birds and 
planting to attract birds. Additive and interactive effects of variables were combined into models based on the thematic grouping of variables and as well as hypotheses suggested by previous research of attitudes towards wildlife. Single variable models assessed the individual predictive power of each variable. This resulted in a candidate set of 14 models. A second candidate set of models was constructed to investigate how experiencing a problem with birds modified the relationship between the four predictors and attitude. Additive and interactive effects of experiencing a problem were modelled with each of the four potential predictors of attitude and experiencing a problem was also included as a single variable model. This resulted in a candidate set of 13 models.

A set of demographic models was constructed and compared to the candidate sets of models comprising predictors of interest to confirm that demographic variables were uninformative in explaining attitude. The candidate model set for this analysis comprised all possible additive combinations of demographic variables.

Within each candidate model set, Akaike Information Criteria (AIC) were used to rank models in order of parsimony. Models with $\triangle \mathrm{AIC}<2$ were considered to have substantial support from the data and models with $\triangle A I C>10$ were considered implausible (Burnham and Anderson 2002). Akaike weights $\left(\omega_{i}\right)$ and evidence ratios were calculated and used to judge the relative power of each model (Burnham and Anderson 2002).

\subsection{Results}

\subsubsection{Questionnaire response}

Six hundred and thirty-five questionnaires were returned, resulting in a $61.8 \%$ response rate. These comprised 26 (86.7\%) of the 30 surveyed residents who had previously reported a kākā sighting or damage, and 611 (61.1\%) of the 1000 
randomly distributed surveys. This compares favourably with response rates of surveys in human-wildlife conflict studies in other countries $(47 \%$, Jonker et al. 2006; 30\%, Dowle \& Deane 2009; 29\%, Thornton \& Quinn 2009) and previous wildlife surveys in Wellington (35\%, Ryan 2011; 43\%, Parker 2009). The majority of questionnaires were returned via mail (mail: $n=553,87 \%$; online: $n=84$, $13 \%)$.

More females than males responded to the survey ( $65 \%$ female) and the majority (85.7\%) of respondents identified themselves as NZ European, with Other (7.9\%) and Asian (2.4\%) the next most common ethnicities. Respondents were highly educated (no formal qualifications 1.9\%; high school qualifications 9.9\%; vocational or trade qualifications $16.8 \%$; bachelor degree $36.4 \%$; postgraduate qualifications $32.7 \%$ ) and wealthy (annual income $<\$ 10,0006.3 \%$, $\$ 10,001-30,00015.4 \%, \$ 30,001-50,00014.8 \%, \$ 50,001-70,00017.4 \%, \$ 70,001-$ $100,00016.2 \%,>\$ 100,00020.7 \%)$. Most survey respondents were aged between $36-50(33.1 \%)$ and $51-70(37.8 \%)$. There were fewer respondents from younger (18-25 6.3\%, 26-35 10.8\%) and older (70+10.7\%) age categories.

Survey respondents differed significantly from the population of the surveyed suburbs. Respondents were older $\left(\chi_{4}^{2}=19.31, p=0.001\right)$, more educated $\left(\chi_{3}^{2}=\right.$ $29.22, p<0.001)$ and wealthier $\left(\chi_{3}^{2}=9.03, p=0.029\right)$ than residents in the suburbs surveyed. There were more female respondents $\left(\chi_{1}^{2}=8.76, p=0.003\right)$ and more Europeans and fewer Maori responding to the survey than resident in the suburbs $\left(\chi_{3}^{2}=15.27, p=0.002\right)$.

Respondents who were delivered a survey due to a previous sighting or damage report were more likely to report a problem (Fisher's exact test, $p=0.017$ ) than randomly selected respondents but there was no significant difference in attitude $\left(\mathrm{t}_{633}=0.401, p=0.688\right.$ ) between the groups.

\subsubsection{Descriptive statistics}

Respondents had high levels of engagement with wildlife (Figure 5.2a). More than half of respondents reported planting trees or plants in order to encourage 
birdlife and a third of respondents put food or water out for birds. Thirty-seven percent $(n=82$ ) of those putting food or water out for birds targeted native species. A quarter of respondents took part in both of these engagement activities. Respondents regularly visited greenspaces (Figure 5.2b). Biodiversity awareness was high, with $95 \%$ of respondents able to identify at least four bird species (Figure 5.2c) and a third able to identify two or more threats to native plants and animals (Figure 5.2d). Invasive species was the most commonly identified threat. 


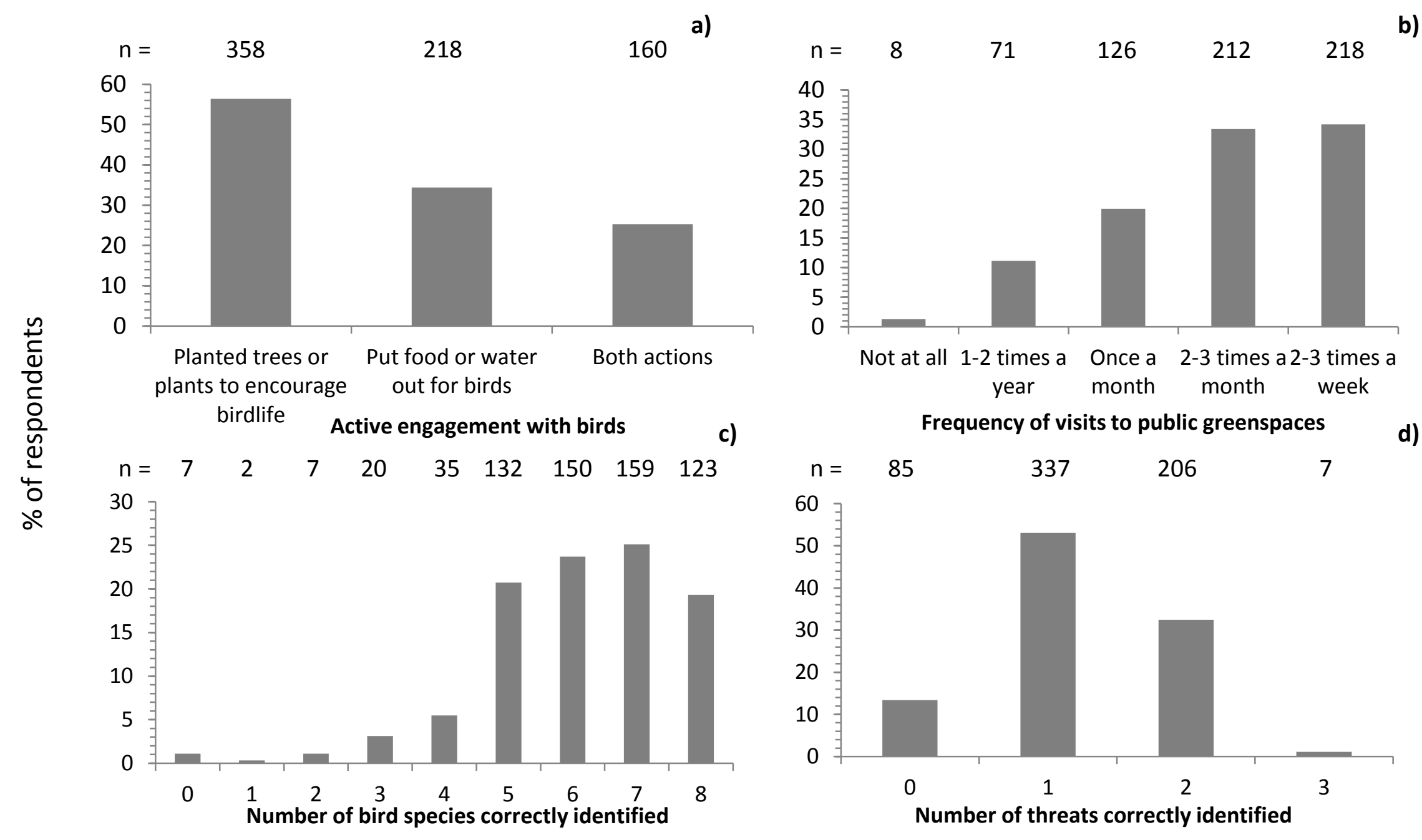

Figure 5.2 Percentage of survey respondents $(n=635)$ that, a) engaged with wildlife by planting trees to encourage birdlife or by putting food or water out for birds, b) visited public green spaces in the past year, by frequency of visitation, c) correctly identified bird species from pictures of 8 different species, and d) correctly identified the three top threats to New Zealand's native plants and animals. 


\section{Bird problems}

A quarter of respondents reported a problem with birds, the majority of which were minor (Figure 5.3a). A third of problems were due to fouling from bird droppings, commonly on washing, cars or outdoor furniture (Figure 5.3b). Damage to gardens and vegetation was also common. Problems in the other category included aggression, removing putty from window frames, damaging furniture and eating pet food.

A quarter of respondents who reported a bird problem listed kākā as causing one or more problems on their property. A quarter of those with kākā problems listed bark stripping as a problem on their property (Figure 5.3c). Although 86\% ( $n=32$ ) of problems caused by kākā were assessed as minor, three respondents experienced moderate problems and two experienced fairly severe problems. Problems caused by other native bird species were reported by $21 \%(n=32)$ of those who experienced a bird problem.

Actions taken to mitigate kākā problems included ceasing or reducing provision of supplementary food, installing nets over fruit trees and scaring away birds using a jet of water from a hose or toy (e.g. water pistol). Two respondents described having to remove trees from their property due to bark damage. One respondent who reported moderate damage from kākā suggested the kākā population should be reduced. 


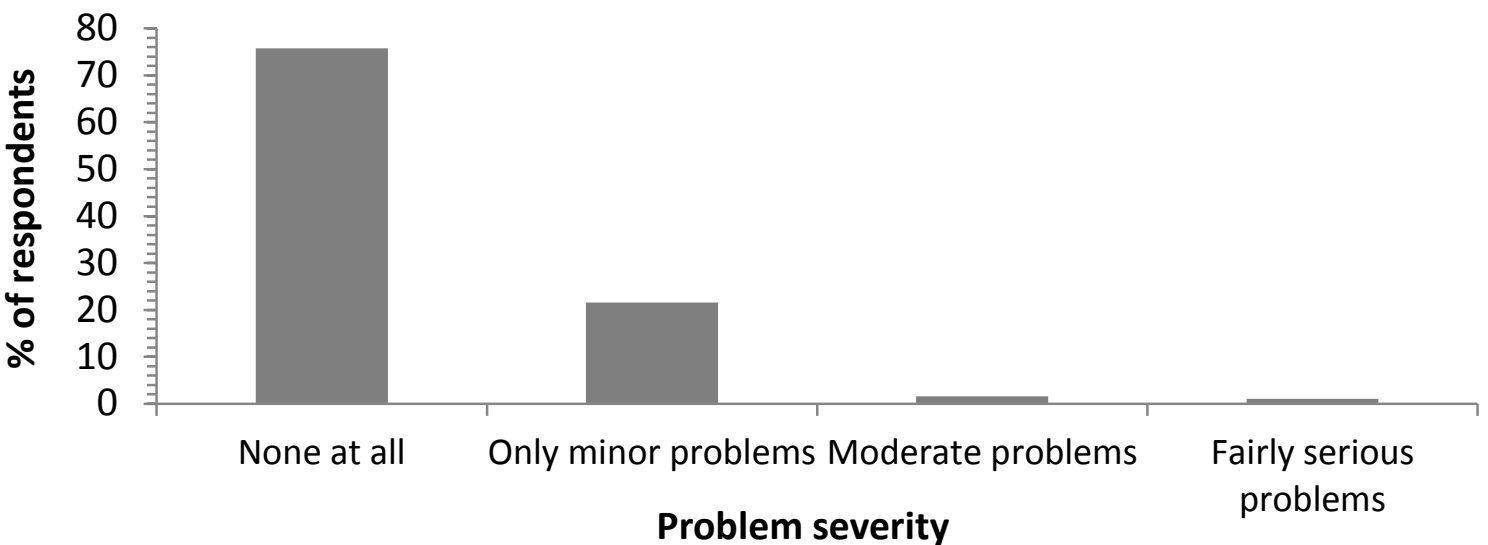

$\mathrm{n}=\quad 61$

16

42

23

15

32

b)

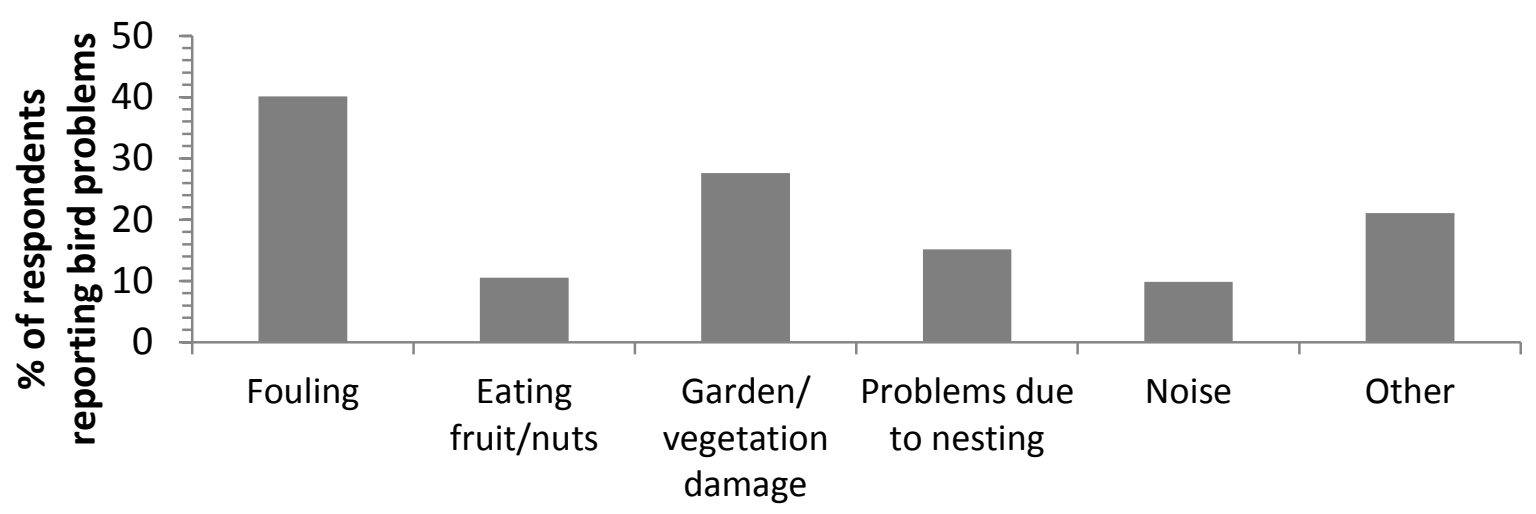

$\mathrm{n}=10$

9

9

Problem cause

$\begin{array}{lll}9 & 8 & 3\end{array}$

3

2 c)

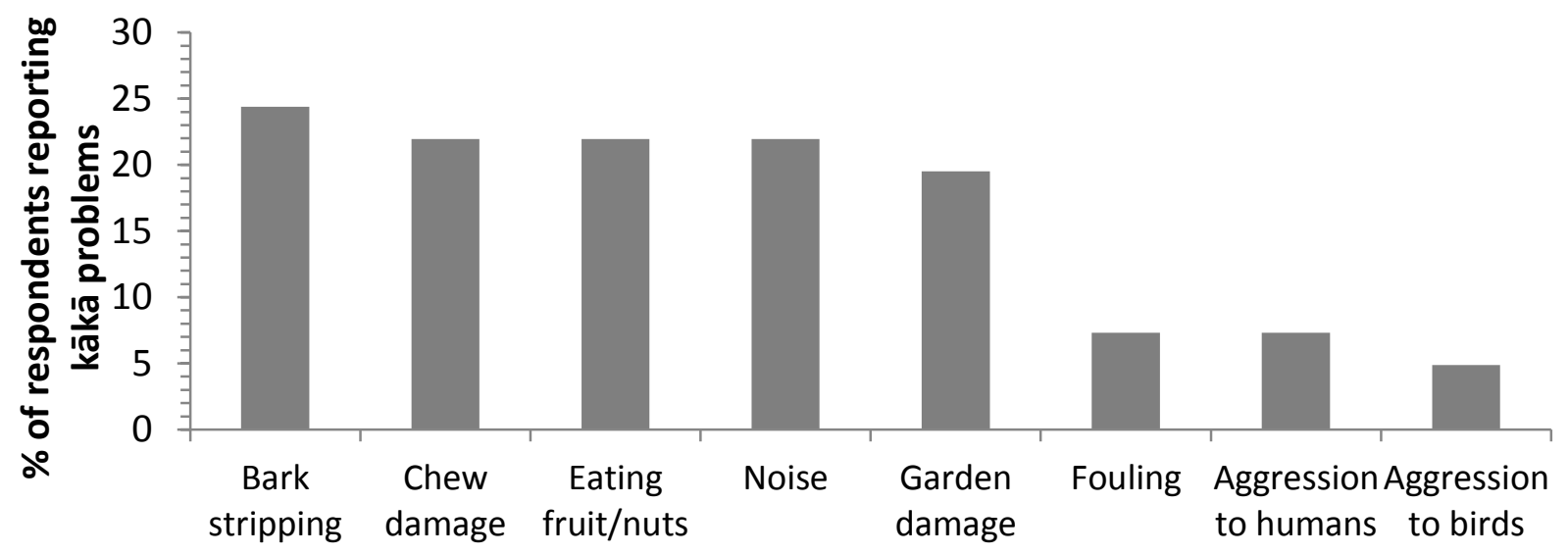

Problem cause

Figure 5.3 a) The percentage of respondents reporting a problem with birds, and the main causes of problems caused by b) all birds and c) kākā. Problem causes are presented as a percentage of $b$ ) the number of respondents reporting a problem $(n=156)$ or $c$ ) number of respondents reporting a problem caused by kākā $(n=41)$. Percentages do not add to 100 as some respondents reported multiple problems with birds or with kākā. 
Native birds are an asset for our city

I enjoy seeing and/or hearing native birds in my neighbourhood

I would like to see an increase in native birds in my neighbourhood

Native wildlife species deserve to be protected

Native wildlife has a right to live in our cities, regardless of problems they may cause

People should tolerate inconveniences and minor damage caused by native wildlife

Non-native birds should be managed if they cause problems or are overabundant

Native birds should be managed if they cause problems or are overabundant

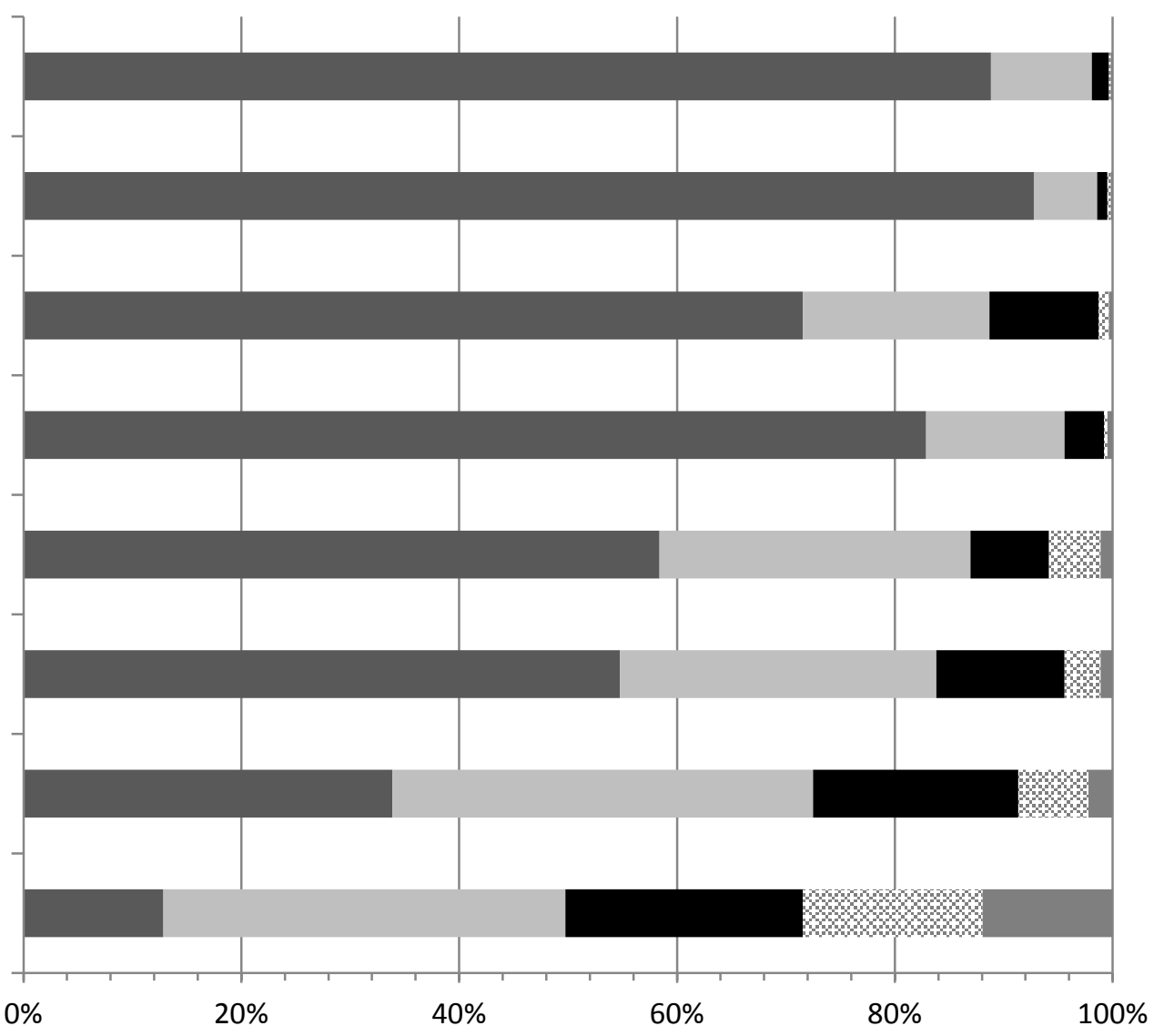

$\square$ Strongly Agree $\quad$ Agree $\square$ Neither agree nor disagree $\otimes$ Disagree $\quad$ Strongly disagree

Figure 5.4 The distribution of responses to the eight questions exploring respondents' attitudes towards birds and bird problems. 


\section{Attitude}

Most survey respondents (98\%) showed highly positive attitudes towards native birds by agreeing or strongly agreeing that they enjoy seeing native birds and considering them a city asset (Figure 5.4). Most respondents (87\%) wanted to see an increase in native birds, although some respondents said they did not want an increase due to the considerable recent population increases. Most respondents (96\%) agreed that native species deserve protection. Respondents were only slightly less positive towards wildlife when asked about attitudes to problems they cause. The majority of respondents (87\%) agreed or strongly agreed that native wildlife has a right to live in a city regardless of problems they may cause and most (84\%) agreed that inconveniences and minor damage should be tolerated. The majority of those who did not agree (12\%) were unsure rather than disagreeing with this question.

Most respondents (73\%) agreed that non-native species should be managed if they cause problems or are overabundant, although there was a high degree (19\%) of uncertainty about this question. Half of respondents thought there should be some degree of management of native species if they cause problems or are overabundant although a high number of respondents (28\%) were opposed to management.

\subsubsection{Model selection analysis}

\section{Data preparation and construct development}

Since the majority of problems were assessed as minor (89\%), experience of a bird problem was converted to a binary variable; either having experienced a problem or not. Bird species identification score and environmental threat score were correlated $(r=0.161 p<0.001)$ and principle component analysis extracted one factor accounting for $58.4 \%$ of the variance $(\lambda=1.167)$ so these two measures were summed to form a composite variable of biodiversity awareness.

Responses to each of the eight attitude questions were highly positively skewed, but the degree of skew and ordinal nature of the data prevented transformation 
to improve the distribution. Bartlett's test of sphericity confirmed that factor analysis was appropriate on the eight attitude items $\left(\chi_{28}^{2}=870.96, p<0.001\right)$ and the Kaiser-Meyer-Olkin measure of sampling adequacy was sufficiently large to suggest good factorability $(\mathrm{KMO}=0.769)$. Two factors were extracted with Eigenvalues greater than 1, which accounted for $48.8 \%$ of the common variance (Table 5.1). The first six questions concerning attitude to birds and bird damage were loaded onto one factor, labelled attitude to birds $(\lambda=3.41)$, and the two final questions were identified as a second factor, labelled attitude to management $(\lambda=1.526)$. The second factor was discarded from further analysis as attitude toward management is not the focus of this study. Cronbach's alpha demonstrated high internal reliability of the factor attitude to birds $(\alpha=0.822$ ) and each of the six items improved the alpha value.

Seventeen respondents failed to answer more than one survey question (comprising a missing value for income and one or more other demographic variables) and were removed from further analysis. These respondents were not significantly different from the remaining dataset in response to attitude questions ( $\left.t_{592}=-1.383, p=0.167\right)$, sex (Fisher's exact test, $p=0.544$ ) or reports of problems (Fisher's exact test $p=0.749$ ). Forty respondents failed to provide income data and missing values analysis suggested that income data were missing at random (Little's MCAR $\chi_{7}^{2}=18.370, p=0.010$ ). Data that are missing at random (c.f. missing completely at random) are missing independently of the relevant variable (income) and since they follow the same multivariate patterns as complete cases they can be predicted (Schafer \& Graham 2002). Data imputation resulted in a complete dataset for 594 respondents.

Planting for birds was correlated with greenspace visitation (Appendix I Table Al.2, $\left.r_{r b}=0.114, p=0.005\right)$, biodiversity awareness $\left(r_{r b}=0.148, p<0.001\right)$ and feeding $\left(r_{\varphi}=0.255, p<0.001\right)$. Greenspace visitation was also correlated with awareness $\left(r_{r b}=0.182, p=0.001\right)$. Since associations were low to moderate and 
models contained a small number of parameters, variables were placed together in models despite association.

The ordinal demographic variables, age, education and income, were significantly associated with between one and three predictors of interest (Appendix I Table Al.3, greenspace visitation: age $r_{s}=-0.16 p<0.001$, education $r_{s}=0.13 p=0.002$; awareness: education $r_{s}=0.14 p=0.001$, income $r_{s}=0.09 p=0.024$; feeding birds: age $\chi_{4}^{2}=34.95 p<0.001$, education $\chi^{2}{ }_{4}=24.01 p<0.001$; planting for birds: age $\chi^{2}$ $\left.{ }_{4}=23.64 p<0.001\right)$. Dichotomous variables, sex and ethnicity, were not significantly associated with predictors of interest. Due the high proportion of demographic variables associated with predictors of interest, it was unnecessary to include demographic variables in candidate models for model selection and inference. 
Table 5.1 Rotated factor matrix obtained during exploratory factor analysis of the eight questions used to explore respondents' attitude to birds and bird problems.

\begin{tabular}{|c|c|c|}
\hline & \multicolumn{2}{|c|}{ Factor } \\
\hline & 1 & 2 \\
\hline People should tolerate inconveniences and minor damage caused by native wildlife & .739 & .120 \\
\hline Native wildlife has a right to live in our cities, regardless of problems they may cause & .734 & .127 \\
\hline Native wildlife species deserve to be protected & .730 & -.161 \\
\hline I would like to see an increase in native birds in my neighbourhood & .688 & .022 \\
\hline I enjoy seeing and/or hearing native birds in my neighbourhood & .670 & -.164 \\
\hline Native birds are an asset for our city & .564 & -.205 \\
\hline Native birds should be managed if they cause problems or are overabundant ${ }^{1}$ & .241 & 669 \\
\hline Non-native birds should be managed if they cause problems or are overabundant ${ }^{1}$ & -.025 & .644 \\
\hline
\end{tabular}




\section{Structural equation modelling}

Confirmatory factor analysis failed to find support for the measurement model as shown by the mean chi-squared value $\left(\chi^{2}{ }_{9}=161.188, p<0.001\right)$, Bollen-Stine $p$ value $(p=0.002)$ and model fit indices $(\mathrm{CMIN} / \mathrm{DF}=17.910, \mathrm{RMR}=0.009, \mathrm{GFI}=$ 0.909). Structural equation modelling is not robust to departures from normality (Kline 2005) and the lack of support for the measurement model may have been due to extreme positive skew in the dependant variable.

\section{Information-Theoretic model selection and inference}

Despite the failure of SEM, high internal reliability and validity of the attitude construct indicated by the EFA and Cronbach's alpha confirm that the six attitude questions collectively measure a meaningful construct. When attitude was converted to a binary variable, $73 \%$ of respondents $(n=436)$ had positive attitudes, the remaining $27 \%(n=158)$ had neutral or negative attitudes towards birds.

In the first set of candidate models, the model comprising the single variable of planting for birds was the only model to have substantial support ( $\triangle \mathrm{AIC} \leq 2$, Table 5.2a). The Akaike weight of this model was more than ten times that of any other model in the set $\left(\omega_{i}=0.873\right)$ and all other models had comparatively trivial individual Akaike weights $\left(\omega_{i}<0.05\right)$. The confidence set of models $\left(\sum \omega_{i} \geq 0.95\right)$ comprised four models and all included planting for birds in addition to or interacting with greenspace visitation or biodiversity awareness.

In the second analysis, the additive and interactive effects of experiencing a problem with birds substantially improved support for all four predictors of attitude ( $\triangle \mathrm{AIC}>2$, Table $5.2 \mathrm{~b}$ ). Greatest support from the data was found for the models of planting and experiencing a bird-related problem and the confidence model set was comprised of these two models only. Both additive ( $\mathrm{AIC}=667.8$, $\left.\omega_{i}=0.568\right)$ and interactive effects (AIC $\left.=668.5, \omega_{i}=0.400\right)$ of these two variables had substantial support. The models of planting for birds and experiencing a problem generated similar support to the model of planting for birds on its own (Table 5.2, AIC $=667.8$ ) despite having an additional one or two parameters. 
Models that did not contain the variable planting for birds were implausible ( $\triangle A I C>10)$. Reporting a bird-related problem on its own was not found to explain residents' attitude $\left(\triangle \mathrm{AIC}=17.50, \omega_{i}=0.000\right)$.

The demographic analysis confirmed that sex, age, ethnicity, income and education did not explain respondents' attitude. No demographic model was plausible i.e. within $\triangle \mathrm{AIC}<10$ of the highest ranking models of the predictors of interest (Appendix IV, highest ranking model: age, AIC = 690.1).

The proportion of respondents with a positive attitude towards birds was higher for respondents who had planted on their properties to attract birds even when they had experienced a problem (Figure 5.5a). There was a greater difference in the proportion of positive attitudes between those who had and had not experienced a problem for respondents who did not plant for birds than for those who had planted for birds. Respondents who had not experienced a problem with birds had a higher proportion of positive attitudes across all levels of greenspace visitation (Figure 5.5b), biodiversity awareness (Figure 5.5c) and whether they fed birds or not (Figure 5.5d). However, these variables were not necessary to explain attitude when planting for birds was considered. 
Table 5.2 The two candidate model sets, a) 14 candidate models for the initial analysis exploring four potential predictors of attitude towards birds, and $b$ ) the 13 candidate models for the final analysis exploring the impact of experiencing a problem on the four potential predictors of attitude towards birds. Models are in descending order of Akaike Information Criterion (AIC).

${ }^{A}$ No. of estimating parameters in candidate model.

a)

\begin{tabular}{lllll}
\hline Predictors & $\mathrm{K}^{\mathrm{A}}$ & $\mathrm{AIC}$ & $\Delta \mathrm{AIC}$ & $\omega_{i}$ \\
\hline Planting & 2 & 667.8 & 0.00 & 0.873 \\
Planting + Greenspace & 3 & 674.0 & 6.20 & 0.039 \\
Planting * Greenspace & 4 & 675.3 & 7.50 & 0.021 \\
Awareness + Planting & 3 & 675.4 & 7.60 & 0.020 \\
Feeding + Planting & 3 & 675.5 & 7.70 & 0.019 \\
Greenspace + Feeding + Planting & 4 & 675.8 & 8.00 & 0.016 \\
Feeding * Planting & 4 & 677.5 & 9.70 & 0.007 \\
Greenspace + Awareness + Feeding + Planting & 5 & 677.6 & 9.80 & 0.006 \\
Greenspace + Feeding & 3 & 688.9 & 21.10 & 0.000 \\
Greenspace & 2 & 689.1 & 21.30 & 0.000 \\
Feeding & 2 & 690.1 & 22.30 & 0.000 \\
Awareness + Greenspace & 3 & 690.6 & 22.80 & 0.000 \\
Feeding * Greenspace & 4 & 690.7 & 22.90 & 0.000 \\
Awareness & 2 & 691.7 & 23.90 & 0.000 \\
\hline
\end{tabular}

b)

\begin{tabular}{lllll}
\hline Predictors & $\mathrm{K}^{\mathrm{A}}$ & $\mathrm{AIC}$ & $\Delta \mathrm{AIC}$ & $\omega_{i}$ \\
\hline Planting + Problem & 3 & 667.8 & 0.00 & 0.568 \\
Planting * Problem & 4 & 668.5 & 0.70 & 0.400 \\
Planting & 2 & 673.6 & 5.80 & 0.031 \\
Greenspace + Problem & 3 & 684.7 & 16.90 & 0.000 \\
Feeding + Problem & 3 & 684.8 & 17.00 & 0.000 \\
Greenspace * Problem & 4 & 685.2 & 17.40 & 0.000 \\
Problem & 2 & 685.3 & 17.50 & 0.000 \\
Awareness * Problem & 4 & 685.5 & 17.70 & 0.000 \\
Awareness + Problem & 3 & 686.5 & 18.70 & 0.000 \\
Feeding * Problem & 4 & 686.8 & 19.00 & 0.000 \\
Greenspace & 2 & 689.1 & 21.30 & 0.000 \\
Feeding & 2 & 690.1 & 22.30 & 0.000 \\
Awareness & 2 & 691.7 & 23.90 & 0.000 \\
\hline
\end{tabular}




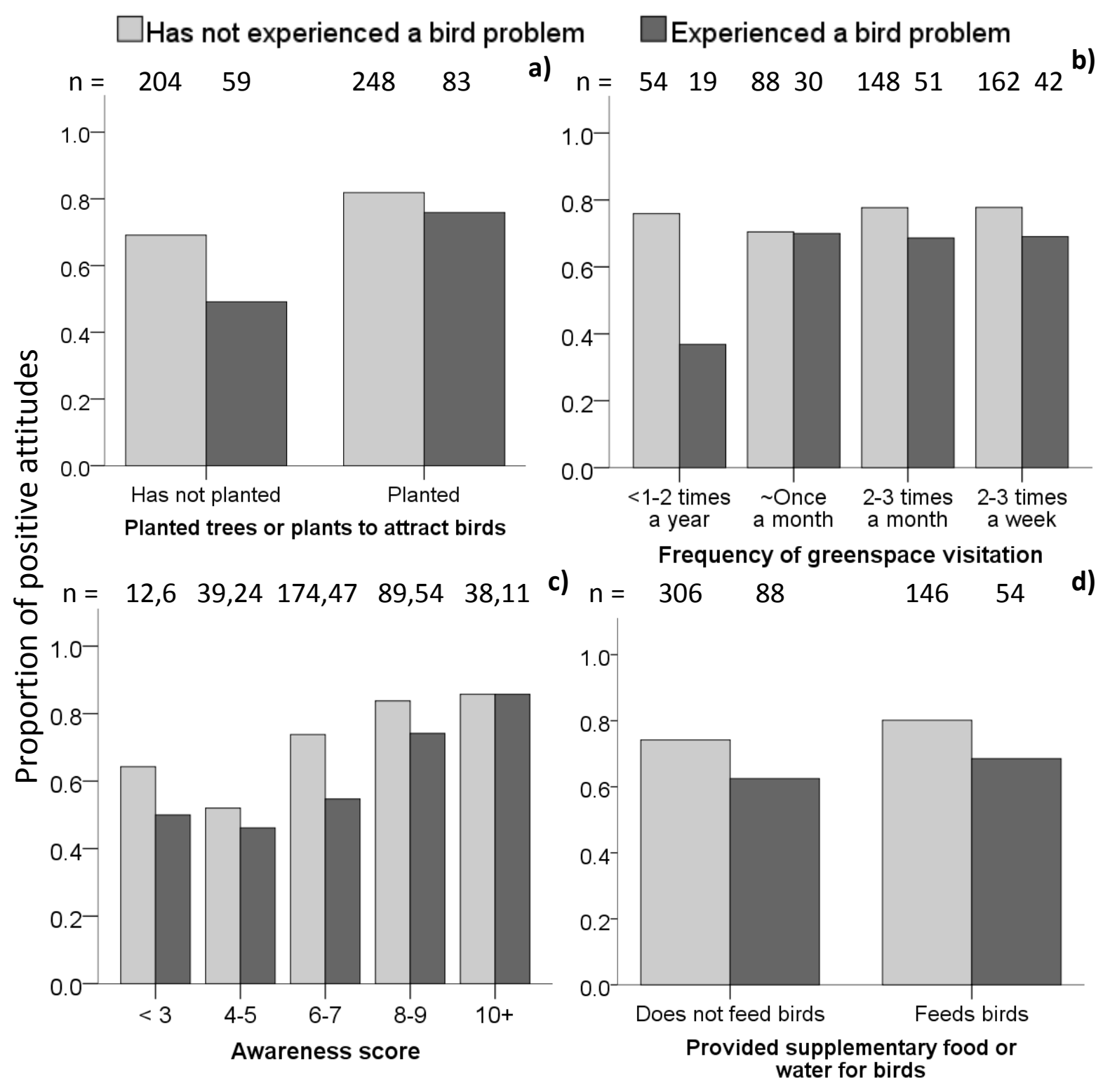

Figure 5.5 Proportion of respondents with a positive attitude towards birds according to whether they reported having experienced a problem with birds across each of the four predictors of attitude, a) planting trees or plants to attract birds, b) greenspace visitation, c) biodiversity awareness, and d) providing supplementary foods or water for birds. 


\subsection{Discussion}

The attitude of Wellington City residents to birds and bird problems was most closely linked to whether a respondent had planted on their property to attract birds. Respondents who had planted for birds were more likely to have positive attitudes towards birds even if they reported experiencing a problem with birds. Similar trends were found for greenspace visitation, biodiversity awareness, and providing supplementary food for birds, but these variables were less strongly associated with attitude.

\subsubsection{Experiencing bird problems}

Residents who had experienced a problem with birds were more likely to have negative attitudes across all levels of awareness and engagement with birds and natural spaces. Those with less positive attitudes towards birds may be more likely to assess and report minor damage and annoyances as a problem or, conversely, experiencing a bird problem may lead to reduced positive attitudes. Experiencing a problem with birds, however, was not by itself an influential predictor of a person's attitude. Since the majority of problems reported by residents were minor, this demonstrates that people may tolerate annoyances and minor damage caused by birds such that these experiences do not have a significant impact on attitudes. Previous studies of human-wildlife conflicts in other countries have also found that attitudes may be relatively robust to annoyances caused by wildlife (Jones \& Thomas 1998; Jonker et al. 2006) and that people are willing to tolerate damage and other nuisances until they lead to safety concerns or economic loss (Wittmann et al. 1998; Coluccy et al. 2001).

Although the majority of bird problems currently experienced by Wellington City residents are minor, if the city's kākā population continues to increase in size and distribution, damage and other problems may become more severe and widespread. Kākā problems described by survey respondents included threatening or 'attacking', causing damage to the roof, weatherboards, spouting 
and decking of homes, and damaging trees, in some cases necessitating their removal. Hence, kākā have the potential to cause both economic costs and pose a threat to people's safety. Tree or branch removal is costly and may be necessary to reduce the safety risks of damaged trees. Wildlife damage to sites of historic and cultural value does not appear to have been researched previously and was not explicitly evaluated in this study, however the destruction of highly valued places and public property, like the Wellington Botanic Garden, may have additional impacts on people's attitudes. Hence, if kākā problems increase in severity, they may have a greater impact on people's attitudes.

\subsubsection{Predictors of attitude}

Whether a respondent had planted trees or plants on their property in order to attract birds had a considerably stronger relationship with attitude than a person's experience of a bird problem or their biodiversity awareness, feeding of birds or engagement with natural areas. Engaging with birds by planting was associated with greater tolerance of bird problems. Respondents who had planted for birds and reported a problem were more likely to have positive attitudes than respondents who did not plant for birds even if they did not report bird-related problems. A smaller disparity in attitude between those reporting and not reporting a bird-related problem was associated with residents who planted for birds.

Planting to attract birds is a direct and powerful way of engaging with wild birds by improving habitat and resource availability and increasing opportunities to view and appreciate birds. The relationship between planting and attitude is likely to be bidirectional; people who appreciate and enjoy watching birds are more likely to invest time and resources into attracting them to their backyards and higher exposure to the birds attracted to plantings is likely to further increase or strengthen attitudes. People with more positive attitudes may then be less likely to assess minor damage or annoyances as problems. These links 
may be reinforced over time because although the planting may be a single event, residents can continue to engage with birds by observing them on their property and relate the birds' presence to their actions. Further study is required to determine how strong the bi-directional relationships between attitude, experience of problems and planting for birds are.

Planting on a residential property to attract birds involves a high level of engagement as it requires motivation and planning, knowledge of plant species, financial resources and gardening skills. Despite this, more than half of survey respondents had planted on their property to attract birds. Unlike other engagement activities, such as providing supplementary food, planting creates connections not just between urban residents and wildlife but also with ecological processes, cycles of plant growth and fosters a sense of connection to place (Moskell et al. 2010). These wider connections are also likely to be important in fostering attitudes to wildlife and to the natural world more generally and may contribute to the value a person places on biodiversity conservation.

It is possible that planting to attract birds may buffer the effects of experiencing conflict with wildlife. Direct experiences may lead to attitudes that are stronger, more stable over time and more resistant to change in response to external influences (Fazio \& Zanna 1981; Fazio et al. 1982). Hence, positive attitudes fostered through engagement activities such as planting for birds may be more likely to persist despite negative experiences with birds, in comparison to attitudes fostered through indirect experience such as learning about birds or incidentally watching them during visits to public greenspaces. People who engage with birds by providing natural foraging opportunities instead of providing supplementary food may also be more likely to have an ecosystems view of nature. This may be linked to a greater tolerance for problems as people may be more likely to appreciate the complexity of ecological interactions and 
recognise the contribution of human encroachment and habitat modification to wildlife issues.

There also appeared to be an important, albeit weak, relationship between bird problems and attitude at low levels of greenspace visitation. Birds are a conspicuous part of many natural areas, particularly in Wellington City where large and/or noisy native birds such as tui (Prosthermadera novaseelandae), kākā and kereru (Hemiphaga novaeseelandiae) are common, so visiting natural areas may be a way to engage with birds in a less direct way than planting. Those who seldom visit greenspaces are unlikely to have planted for birds and may be generally less engaged and tolerant of urban nature.

The lack of relationship between bird feeding and attitude was surprising as this activity is often seen as an important way for urban residents to connect with nature (Green \& Higginbottom 2000; Jones 2011; Ryan 2011). Although feeding birds is a popular form of engagement, it may not be beneficial to birds and many conservation organisations in New Zealand discourage bird feeding (e.g. Chug 2010). Hence, residents who value and appreciate birds may refrain from feeding birds. Many people who provide supplementary food for birds target exotic species (Parker 2009; Ryan 2011) and native species may be more likely to be attracted by planting. Hence planting to attract birds may increase experience and attitudes towards native species more specifically. Attracting birds through the provision of supplementary food may also be associated with the experience of bird problems as birds may be present in higher numbers and may develop unnatural behaviours or exhibit natural behaviours where they are not welcome (e.g. Beak maintenance by chewing on weatherboards, Temby 2004). Although bird feeding and experiencing problems were not correlated in this study, kākā have caused property damage in Wellington City when attracted by the provision of supplementary food (pers. obs.). People feed birds for a variety of reasons including pleasure, increased bird-watching opportunities, and a desire for 'environmental atonement' (Howard \& Jones 2004; Jones \& Reynolds 2008). 
Planting to attract birds is likely to provide many of these same benefits but may be less likely to generate problems such as high numbers of birds attracted to human provisioned food sources and increased likelihood of nuisance activity due to the reduced time required for foraging.

This survey demonstrates the high levels of interest, engagement and value placed on birds by Wellington City residents. The highly positive attitudes found by this study reflect similarly positive attitudes found in other human dimensions studies of wildlife (Jonker et al. 2006; Dowle \& Deane 2009; Consorte-McCrea 2011), including those of potentially dangerous animals (König 2008; Carlos et al. 2009; Thornton \& Quinn 2009). The high levels of engagement with birdlife found in this study were similar to previous studies in New Zealand and other countries that have found $20-60 \%$ of people feed wildlife (Rollinson et al. 2003; Lepczyk et al. 2004; Ishigame \& Baxter 2007; Parker 2009). High rates of residential planting to attract wildlife were also found in previous studies in Wellington (36\%, Parker 2009) and in the US (50\%, Lepczyk et al. 2004). The high return rate for this survey further suggests the high levels of interest in wildlife of Wellington City residents (White et al. 2005).

\subsubsection{Study limitations}

Although the extraordinarily high return rate of this study minimises the potential problems posed by non-response bias (White et al. 2005), survey respondents differed significantly from the population of the suburbs sampled. In particular, male, non-European, low-income and less-educated residents were not well represented in this study.

Both those with an interest in birds and those who experience bird-related problems may be over-represented in this study, however this is unlikely to have significantly modified outcomes of the modelling of attitude.

This analysis was somewhat limited by the highly skewed nature of the dependant variable. As this was the first reported study of attitudes towards native species in New Zealand the distribution of attitudes was not known. The 
questions used to develop the attitude metric were based on questions from studies of human wildlife conflict in other countries. The highly positive attitudes found in this study may be due to the focus on birds or the lower levels of wildlife conflict currently experienced in New Zealand. Despite this, understanding what leads to non-positive attitudes is of particular interest since targeting these attitudes for management is likely to lead to the greatest increases in tolerance and so will likely have the greatest impact on reducing conflict with kākā.

\subsubsection{Management recommendations}

This study has important implications for kākā conservation in Wellington City. Although the damage caused by kākā currently is relatively minor, the kākā population is growing and damage to trees and property is likely to become more severe and widespread. However, this study shows that attitude and tolerance to birds may be more closely linked to a person's positive experiences with birds than to problems. People's attitudes towards kākā may be relatively robust to problems at least while they remain minor, particularly if they engage with kākā in positive ways.

Ecological solutions to the problem of kākā damage in Wellington City (e.g. planting particular tree species) are likely to be long-term, therefore conflict mitigation in the near-term will need to be based on improving the attitudes and tolerance of residents to problems. Influencing public attitudes to increase tolerance to wildlife problems can be an effective conflict management strategy (Messmer 2000; Consorte-McCrea 2011).

Previous studies have found that people with less positive attitudes to wildlife are more likely to perceive an interaction as negative (Kretser et al. 2009) and are less willing to tolerate damage (Bath et al. 2008). They are also less likely to support species conservation or management that leads to population growth (Kaczensky et al. 2004; Gadd 2005; Jonker et al. 2006; Carlos et al. 2009). Since the majority of survey respondents have extremely positive attitudes, most 
Wellington City residents may be willing to tolerate damage from kākā and may continue to view kākā favourably even if damage increases. Residents with neutral or negative views towards birds however, may be less likely to tolerate kākā damage to trees or property. Strategies to mitigate conflict with kākā in Wellington City should focus on increasing appreciation for kākā and tolerance for problems among those who currently have neutral or negative attitudes, in particular among those who rarely experience or engage with birds.

Although this study did not demonstrate causation, it is possible that increased engagement with birds by planting on private property may lead to more positive attitudes towards them. Hence encouraging residents to plant for birds may be an effective strategy to increase positive attitudes and potentially mitigate conflict. Strategies could include increased promotion and support for residents to plant on their property and research to understand the barriers that prevent people from taking part in this activity. Barriers to planting on private property may include plant cost, lack of gardening knowledge and skills, difficulty in accessing information about plant species, and property tenure (e.g. living in rental accommodation). Labelling plants at garden centres may be an easy way to encourage home owners to select species for planting that are likely to attract native birds. The Wellington City Council Free Plants Program provides plants free of charge for residents to plant on publicly owned land such as road reserves. This may be a way for residents to take part in native planting without the expense of purchasing plants and may be a way for those living in rental accommodation to engage with birds with little financial outlay.

Since there will always be people who are uninterested in engaging with wildlife, encouraging residents who are already actively engaged with birds in other ways may be the most effective strategy to increase the proportion of residents who plant for birds. A third of survey respondents provided supplementary food to birds, yet this engagement activity was not found to be closely related to attitude and may in fact increase the likelihood of experiencing damage or other 
problems. Hence, encouraging those who currently provide supplementary food to modify their engagement method and instead attract birds to their properties by planting may be an effective strategy for conflict mitigation, by potentially reducing feeding-related problems and increasing the tolerance of these residents to bird problems.

Increasing native planting on private properties is also likely to have considerable ecological benefits by increasing habitat connectivity and resource availability for many native species in the urban landscape, and may be a precursor to residents' involvement in habitat restoration beyond their property.

This study suggests that traditional conflict management techniques such as public education campaigns to increase public knowledge and awareness may be ineffective at increasing tolerance to problems. Instead, increasing residents' engagement with birds and encouraging people who feed birds to instead plant trees and plants to attract them may be more effective strategies to mitigate conflict caused by kākā and other birds in Wellington City. 


\section{Chapter Six: Dietary breadth as a predictor of potential avian-human conflict in urban landscapes}

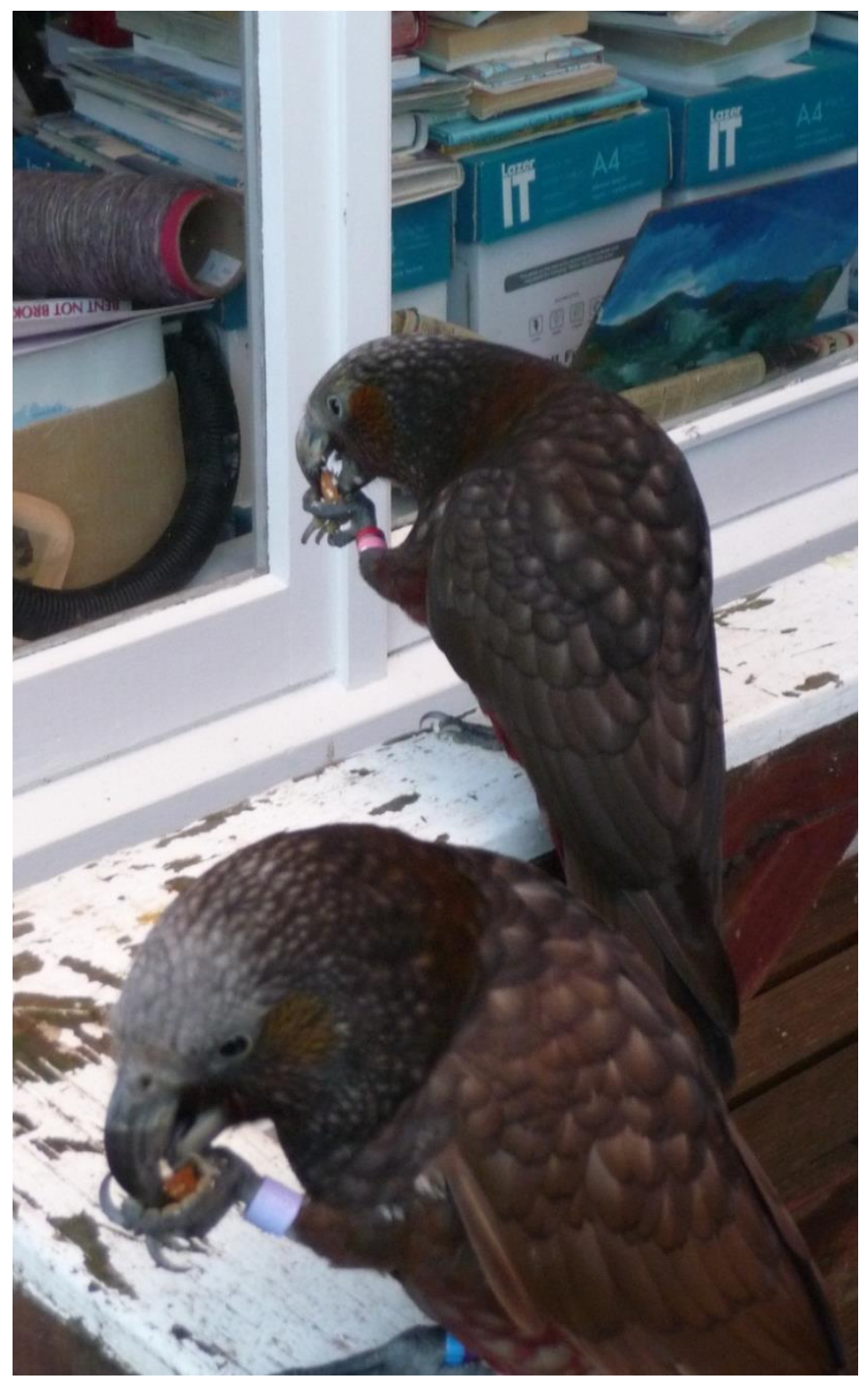

Kākā exploiting supplementary food provisioned by a Wellington City resident.

This chapter has been submitted for publication in Wildlife Research and is currently under review. 


\section{Abstract}

Avian-human conflict is a growing issue in urban areas. Studies of conflict tend to be species and situation specific and focus on landscape characteristics that generate or exacerbate the problem. My objective was to determine characteristics of native bird species that cause conflict in urban areas and to develop a model that can be used to assess the relative likelihood of a New Zealand species causing conflict in the future. Ecological, behavioural and lifehistory characteristics of 33 conflict-causing species identified from the literature and 106 randomly selected non-conflict congeners were compared using an Information-Theoretic approach to multi-model selection and inference. Variables from the confidence set of models $\left(\sum \omega_{i} \geq 0.95\right)$ were used to develop a model that was applied to the New Zealand urban avifauna to provide a relative measure of a species' potential to generate conflict. Model selection based on second-order Akaike Information Criterion indicated that dietary breadth alone best explained conflict $\left(\omega_{i}=0.851\right)$ and conflict species had broader diets $(\bar{x} \pm$ $\mathrm{SE}, 4.1 \pm 0.38$ dietary categories) than non-conflict species (3.1 \pm 0.13$)$. Using dietary breadth, flocking, clutch size, grainivory, territoriality and non-ground nesting - the confidence model set - New Zealand's native pukeko (Porphyrio porphyria), red-billed gull (Larus scopulinus) and kākā (Nestor meridionalis) were identified as the three species most likely to generate conflict with urban residents. Broad dietary requirements may allow a species to take advantage of novel and varied food sources in the urban environment and lead to population growth. Large populations at high density may amplify problems, exceeding residents' tolerance levels and resulting in conflict. Species characteristics relating to nesting, sociality and body size were found to be uninformative. Species with a broad diet, particularly those identified by this study as having a high potential for conflict, should be monitored to identify population growth and the emergence of problems in urban areas. This will allow proactive implementation of management, improving the likelihood of conflict mitigation. 


\subsection{Introduction}

Human-wildlife conflict is increasing in severity and frequency worldwide (Madden 2004) and is one of the most challenging issues facing conservation (Dickman 2010). Wildlife is growing in diversity and abundance in cities (Luniak 2004) and may reach extreme levels (Marzluff 2001) that can lead to conflict with people. Wildlife cause a wide range of problems in cities, including damaging property such as buildings, vehicles and gardens (Conover \& Chasko 1985; Zinn \& Andelt 1999; Temby 2004), and causing nuisance, particularly due to their noise and odour (Temby 2004; Rock 2005). Urban wildlife may also present threats to human safety, through attacks, vehicle collisions, water contamination and the transmission of zoonotic diseases (Zinn \& Andelt 1999; Messmer 2000; Conover 2001; Pruett-Jones et al. 2007).

Studies of human-wildlife conflict in urban landscapes have considered how features of the urban environment may cause or exacerbate the conflict. For example, the availability of anthropogenic food is often implicated in attracting wildlife to urban areas and allowing their populations to grow to larger sizes than would be possible with natural food sources (Belant et al. 1998; Temby 2004; Sha et al. 2009). This is a useful approach because these features of the landscape might then be manipulated to reduce the conflict (e.g. improved food-waste disposal). However, of the many wildlife species living in urban landscapes, only some conflict with people. Considering only features of the urban landscape does not explain why some species become pests while others coexist with people without conflict. Behavioural, ecological and life-history characteristics have been found to be important in determining which species are able to colonise and thrive in urban environments (Luniak 2004; Kark et al. 2007; Evans et al. 2011). In a similar way, species characteristics are likely to determine the propensity of some species to become urban pests. The characteristics of urban conflict species are likely to reflect both characteristics that enable the species to colonise and thrive in the urban environment as well as those that generate the 
conflict. Some characteristics may both increase the ease of urban colonisation and provoke conflict, others may only facilitate one step in this process.

\subsubsection{Potential conflict characteristics of birds}

Birds are an ideal class to use in the development of a model to explain conflict as they are diverse and common in urban landscapes globally (Marzluff 2001). Avifauna currently cause a variety of problems that may result in considerable conflict in urban areas. Nest building can generate problems due to noise, odour, nesting material build-up and property or vegetation damage (Fitzwater 1988; Belant 1997; Temby 2004; Pruett-Jones et al. 2007). Social behaviours, such as communal roosting, nesting and flocking, may cause or exacerbate conflict by concentrating the damage of individuals (Belant 1997; Sacchi et al. 2002; Rock 2005; Taylor et al. 2011). Urban residents may be attacked or intimidated by birds that aggressively defend territories (Fitzwater 1988; Temby 2004) and high population growth rates may allow species to increase to levels exceeding peoples tolerance. Wide dietary breadth may be linked to conflict as it may allow a species to exploit the variety of novel foods in the urban landscape, including refuse (e.g. landfills, waste bins) and supplementary food (Kark et al. 2007). Body size may be linked to conflict as larger animals are more conspicuousness and may be perceived as a safety risk or having a greater potential for damage (Dickman 2010).

Although urban human-wildlife conflict has received increased research attention, studies tend to be species and situation specific and there has been little synthesis across taxa or region. In this study I aimed to identify what ecological, behavioural and life-history characteristics would increase the likelihood of an avian species generating conflict in urban landscapes, using published examples from throughout the world. I develop a profile of traits that increase the likelihood of generating conflict and enable predictions to be made about which bird species are likely to become sources of conflict in the future. Management of urban human-wildlife conflict is challenging and control 
measures often have low success rates (Conover 2001; White \& Ward 2010). Hence, if potential conflict can be pre-empted the success of subsequent management may be significantly improved. The ability to predict what species may cause future conflict would be a valuable tool, allowing managers to monitor potential conflict species and implement control measures before situations become costly or widespread.

Effective predator control in urban and peri-urban reserves, in conjunction with habitat restoration programs, has led to an increase in native bird species in New Zealand cities (Miskelly et al. 2005; Brockie \& Duncan 2012; Waikato Regional Council 2012). New Zealand has few native mammals but a large and diverse native avifauna; hence birds are likely to generate the majority of human-wildlife conflicts. Although current rates of human-wildlife conflict in New Zealand cities are comparatively low, the increasing diversity and abundance of bird species in our cities increases the potential for bird-human conflict. Many of these species are closely related or ecologically similar to species that cause significant conflict overseas. Characteristics of urbanisation, such as increased food availability and altered predator dynamics can generate or exacerbate conflict, thus urban growth and intensification that is occurring in New Zealand (Dixon \& Dupuis 2003; Statistics New Zealand 2006b) may further contribute to increased conflict with birds. Therefore, with little urban bird conflict at present but a potential increase in coming years, New Zealand provides an ideal case study for testing the predictive power of this model. I identify species predicted by the model to have a high likelihood of generating conflict in New Zealand cities in the future.

\subsection{Method}

\subsubsection{Literature review and species selection}

I reviewed the literature to find journal articles, conference proceedings and reports (hereafter publications) describing cases of human-avian conflict in urban 
landscapes. I searched the Google Scholar, Web of Knowledge and Scopus databases using a search strategy that combined any of the keywords; humanwildlife conflict, conflict, problem, pest or damage; with any of; urban, city, cities, residential or suburb. Search results were examined to identify publications describing problems or conflict caused by bird species in urban landscapes. Publications from 1988 to the search date (June 2011) were included in the analysis as literature was sparse and rural-focused before this date. Additionally, the journals Human-Wildlife Interactions (formerly Human-Wildlife Conflicts) and Human Dimensions of Wildlife were searched. The bibliographies of publications identified in the database search were also searched for relevant publications that were obtained if accessible and included in the analysis if they fitted the criteria.

The sample of urban bird-human conflict literature was consulted to generate a list of bird species and main causes of conflict. Studies which described genera but did not specify the species at fault were not included in the analysis, resulting in the exclusion of woodpeckers (Picidae spp.). Species were included in the analysis if the report of conflict occurred within the native biogeographic range of the species. Commensal species thrive in the urban environment and have expanded naturally or with human assistance to cities far beyond their native range (Blair 2001). Commensal species have the potential to bias a study of this sort towards characteristics of synurbanization rather than conflict. Hence, although many commensals cause significant conflict, this study considered only species that cause conflict in urban areas within their native range.

For each conflict causing species, up to four other species from the same genus that have not been identified in the scientific literature as causing conflict were randomly selected (refer to Appendix $\mathrm{V}$ for species list). This generated a reasonable sample size for analysis but avoided biasing the sample towards genera with higher numbers of species. Genera with only one species and those with insufficient information on non-conflict congeners were excluded, resulting 
in the removal of the Australian brush turkey (Alectura lathami), galah (Eolophus roseicapillus), monk parakeet (Myiopsitta monachus), turkey vulture (Cathartes aura) and black vulture (Coragyps atratus) from the analysis.

The list of conflict species compiled for this study is not exhaustive. It is likely that many species, even those causing fairly significant conflicts, have not been the subject of scientific study. It is likely however, that funding and research effort are directed at the species causing the greatest problems. Hence it can be said that the conflict species compiled cause significant problems and are likely to cause more severe and extensive problems than other species from which the non-conflict list was compiled.

\subsubsection{Model development and data collection}

An Information-Theoretic (IT) approach was adopted to test hypotheses about species characteristics that cause conflict. An IT approach allows the testing of $a$ priori models based on prior research or theory by quantitatively ranking and weighting competing hypotheses evidentially (Burnham \& Anderson 2002). Models are ranked based on model fit and parsimony (i.e., preference is given to models with fewer parameters to avoid overfitting, Burnham \& Anderson 2002). The IT approach is superior to stepwise modelling (Johnson \& Omland 2004) and ensures that data dredging is avoided (Burnham \& Anderson 2002). A suite of 15 candidate models of species characteristics that may lead to conflict was compiled using examples of urban bird conflict from the literature.

Data for species characteristics were obtained from Handbook of the Birds of the World (del Hoyo et al. 1992) and referred to traits of the species within its native range and habitat. Mean body size was determined as the mean of the range given for males and females combined. Species were defined as non-colonial breeders if they were recorded as breeding solitarily or in small ( $<10$ individuals) groups in all instances. Species were recorded as forming flocks or defending territories only if this was stated by del Hoyo et al. (1992). Species were classified into nine dietary categories: granivore, folivore, frugivore, nectivore, insectivore, 
marine invertebrate predator, terrestrial predator, piscivore or scavenger. The number of dietary categories a species consumed was summed to obtain a score of diet breadth. Nest types were categorised by placement; ie. ground, cliff, cavity or tree/platform/other raised nest type and were recorded as being built using external materials if any material other than down, feathers or faeces was used in their construction. Non-ground nesting was defined as having one or more of the nest positions; cliff, cavity or tree/platform/other raised nest type. Clutch size was calculated as the median value of typical clutch size range.

\subsubsection{Analysis}

Collinearity of predictor variables was examined using a matrix of Pearson's and point biserial correlation coefficients and phi coefficients to measure associations between quantitative-quantitative, quantitative-dichotomous and dichotomous-dichotomous variables respectively (Appendix I Table AI.3). Models containing correlated or associated variables were modified to remove redundant variables. This resulted in the deletion of two full models as they were identical to current models after variable removal (Colonial nesting + Diet breadth, Flocking + Colonial Nesting) and the simplification of an additional model (Tree or cliff nesting removed from Nest colonially + Constructed nests + Tree or cliff nesting). This resulted in a suite of 13 models for analysis (Table 6.1).

To evaluate the effect of species characteristics as potential determinants of conflict the binary response variable conflict was modelled as a generalized linear function on a logit scale using R (Version 2.15.2, The R Foundation for Statistical Computing 2012). A preliminary analysis was run of all 12 fixed-effect predictor variables (the 'global model') with and without genus included as a random effect. The addition of genus did not improve the fit of the model (AICC global model $=157.342, \mathrm{AlCC}_{\text {global }}$ model + genus $\left.=159.787\right)$. Removing the random effect is justified because this analysis indicates that the dependant variable, conflict, is independent of taxonomic relationships. Therefore, despite phylogenetic 
structuring in the data, genus was not included as a random effect in further statistical analysis to improve parsimony.

Akaike Information Criterion adjusted for small-sample size (AICC) was calculated for each of the 13 models in the way described by Burnham and Anderson (2002). Relative power of each model was judged by comparing AICc, Akaike weights $\left(\omega_{i}\right)$ and evidence ratios (Burnham \& Anderson 2002). Models with $\triangle \mathrm{AICC}$ $\leq 2$ were considered to have compelling support from the data and models with $\triangle \mathrm{AICC}>10$ were considered implausible (Burnham and Anderson 2002).

To assess the potential of New Zealand urban bird species to generate conflict, the six variables from the confidence set of models $\left(\sum \omega_{i}=0.95\right)$ were rerun as a single model. Bird species listed by Brockie (1997) as living in New Zealand urban areas $(n=17)$ were assessed using this model. The kākā was also assessed due to the emerging conflict being generated by the recently reintroduced Wellington urban population (Charles 2012). Data for species characteristics was obtained from del Hoyo et al. (1992) as described earlier for conflict species. Coefficients from the confidence model were used to obtain a value indicating the relative likelihood of each New Zealand species generating conflict. Values for a 'worst case' and 'best case' (maximum and minimum values respectively of each species character) were calculated for comparison. 
Table 6.1. The candidate models for conflict between humans and bird species in urban areas.

Models are in descending order of second-order Akaike Information Criterion (AICC).

\begin{tabular}{|c|c|c|c|c|c|c|}
\hline Variables & Justification & Species examples & $\mathrm{K}^{\mathrm{A}}$ & AICC & $\Delta \mathrm{AICc}$ & $\omega_{i}$ \\
\hline Diet breadth ${ }^{1,2,3,4}$ & $\begin{array}{l}\text { Species that can feed from diverse food } \\
\text { sources, particularly anthropogenic waste, may } \\
\text { increase in population size and density leading } \\
\text { to conflict. }\end{array}$ & $\begin{array}{l}\text { American crow; Australian } \\
\text { white ibis; ring-billed, herring } \\
\text { \& silver gulls }\end{array}$ & 2 & 147.078 & 0.000 & 0.851 \\
\hline Flocking $^{1,3,5}$ & $\begin{array}{l}\text { Bird flocks cause conflict due to noise, fouling, } \\
\text { odour and disease transmission. }\end{array}$ & $\begin{array}{l}\text { Common grackle, blackbird, } \\
\text { American robin, corella, galah }\end{array}$ & 2 & 153.608 & 6.530 & 0.033 \\
\hline Clutch size ${ }^{6}$ & $\begin{array}{l}\text { High fecundity may improve ability to colonise } \\
\text { the urban landscape. }\end{array}$ & & 2 & 154.248 & 7.170 & 0.024 \\
\hline Granivore $^{3,7}$ & $\begin{array}{l}\text { Granivorous species may be more common in } \\
\text { urban landscapes and can exploit grain provided } \\
\text { as supplementary food by urban residents. }\end{array}$ & Sulphur-crested cockatoo & 2 & 154.468 & 7.390 & 0.021 \\
\hline Territorial ${ }^{1,8}$ & $\begin{array}{l}\text { Territorial species may threaten, frighten or } \\
\text { attack people in urban areas. }\end{array}$ & $\begin{array}{l}\text { Australian magpie, Mississippi } \\
\text { kite, mockingbird, masked } \\
\text { lapwing }\end{array}$ & 2 & 155.688 & 8.610 & 0.011 \\
\hline $\begin{array}{l}\text { Non-ground } \\
\text { nesting }\end{array}$ & $\begin{array}{l}\text { Species that nest above the ground may be } \\
\text { favoured by urban development. }\end{array}$ & & 2 & 155.978 & 8.900 & 0.010 \\
\hline Body size $e^{10}$ & $\begin{array}{l}\text { Larger bodied species are more conspicuous } \\
\text { and may be assessed as a greater risk. }\end{array}$ & Baboon, African elephant & 2 & 155.998 & 8.920 & 0.010 \\
\hline $\begin{array}{l}\text { Colonial } \\
\text { nesting }\end{array}$ & $\begin{array}{l}\text { Noise, odour, fouling and conspicuousness of } \\
\text { nesting colonies may lead to conflict. }\end{array}$ & $\begin{array}{l}\text { Herring gull, ring-billed gull, } \\
\text { Australian white ibis }\end{array}$ & 2 & 156.208 & 9.130 & 0.009 \\
\hline Cavity nesting ${ }^{1,3}$ & Nesting in building walls, beams and cavities & Welcome swallow, chimney & 2 & 156.268 & 9.190 & 0.009 \\
\hline
\end{tabular}


may lead to conflict due to noise, odour and fouling.

Constructed nests $^{12}$

Tree or Cliff nesting ${ }^{12,13}$

Colonial nesting + Constructed nests 12,14

Build-up of nesting materials clogs drains and causes water and structural damage.

Cliff and tree nesting species may modify behaviour to utilise roofs as nesting platforms, leading to conflict due to fouling, drainage obstruction and structural damage.

Large quantities of nesting material may build

up causing drain obstruction and building damage.

Colonial nesting + Large nesting colonies in trees in urban areas Tree nesting ${ }^{15}$ may cause habitat destruction. swift

Herring gull, ring-billed gull

$2 \quad 156.278 \quad 9.200$

0.009

Herring gull, ring-billed gull

$2 \quad 156.448 \quad 9.370$

0.008

Herring gull, ring-billed gull

$3 \quad 158.088 \quad 11.010 \quad 0.003$

Double-crested cormorant

${ }^{\mathrm{A}}$ No. of estimating parameters in candidate model.

${ }^{1}$ Fitzwater 1988, ${ }^{2}$ Belant et al. 1998, ${ }^{3}$ Temby 2004, ${ }^{4}$ Kark et al. 2007, ${ }^{5}$ Barnes \& Constantin 1993, ${ }^{6}$ Moller 2009, ${ }^{7}$ Fuller et al. 2008, ${ }^{8}$ Jones and Thomas 1999, ${ }^{9}$ Evans 2011, ${ }^{10}$ Dickman 2010, ${ }^{11}$ Martin et al. 2010, ${ }^{12}$ Belant et al. 1997, ${ }^{13}$ Sacchi 2002, ${ }^{14}$ Rock $2005,{ }^{15}$ Taylor 2011 


\subsection{Results}

Forty publications were found describing bird species that cause conflict in urban areas in their native range. Thirty-two conflict causing species were identified and used in the analysis, matched with between one and four non-conflict congeners for a total of 139 species (Appendix IV). Twenty-two species (69\% of conflict species) primarily caused conflict due to nesting or roosting behaviours. Six species (19\%) induced conflict through aggressive behaviour or attacking humans, four (13\%) were the subject of complaints due mainly to fouling unrelated to roosting and nesting and one species, the sulphur-crested cockatoo (Cacatua galerita), generated conflict by damaging buildings and outdoor furniture.

The model containing the single variable dietary breadth was found to have greatest support from the data $\left(\omega_{i}=0.851\right.$, Table 6.1$)$ and was the only model to have substantial support $(\triangle \mathrm{AIC} \leq 2)$. All other models had trivial individual Akaike weights $\left(\omega_{i}<0.05\right)$. Conflict species had a greater dietary breadth $(\bar{x}=4.1$ dietary categories $\pm 0.38 \mathrm{SE}$ ) than non-conflict species ( $\bar{x}=3.1$ dietary categories $\left.\pm 0.13 \mathrm{SE}, t_{39}=-2.502, p=0.017\right)$. Twenty-seven percent $(n=9)$ of conflict species had 6 or more dietary types, compared to $2 \%(n=3)$ of non-conflict species (Figure 6.1).

The confidence set of models $\left(\omega_{i} \geq 0.95\right)$ comprised six single-variable models, including the variables diet breadth, flocking, clutch size, grainivory, territoriality and non-ground nesting. Using this model the pukeko (Porphyrio porphyria), redbilled gull (Larus scopulinus) and kākā (Nestor meridionalis) were identified as the three species most likely to cause conflict in New Zealand cities (Table 6.2). The spur-winged plover (Vanellus miles), the kingfisher (Todiramphus sancta), and the paradise shelduck (Tadorna variegata) were also identified as having a high likelihood of generating conflict in New Zealand. 


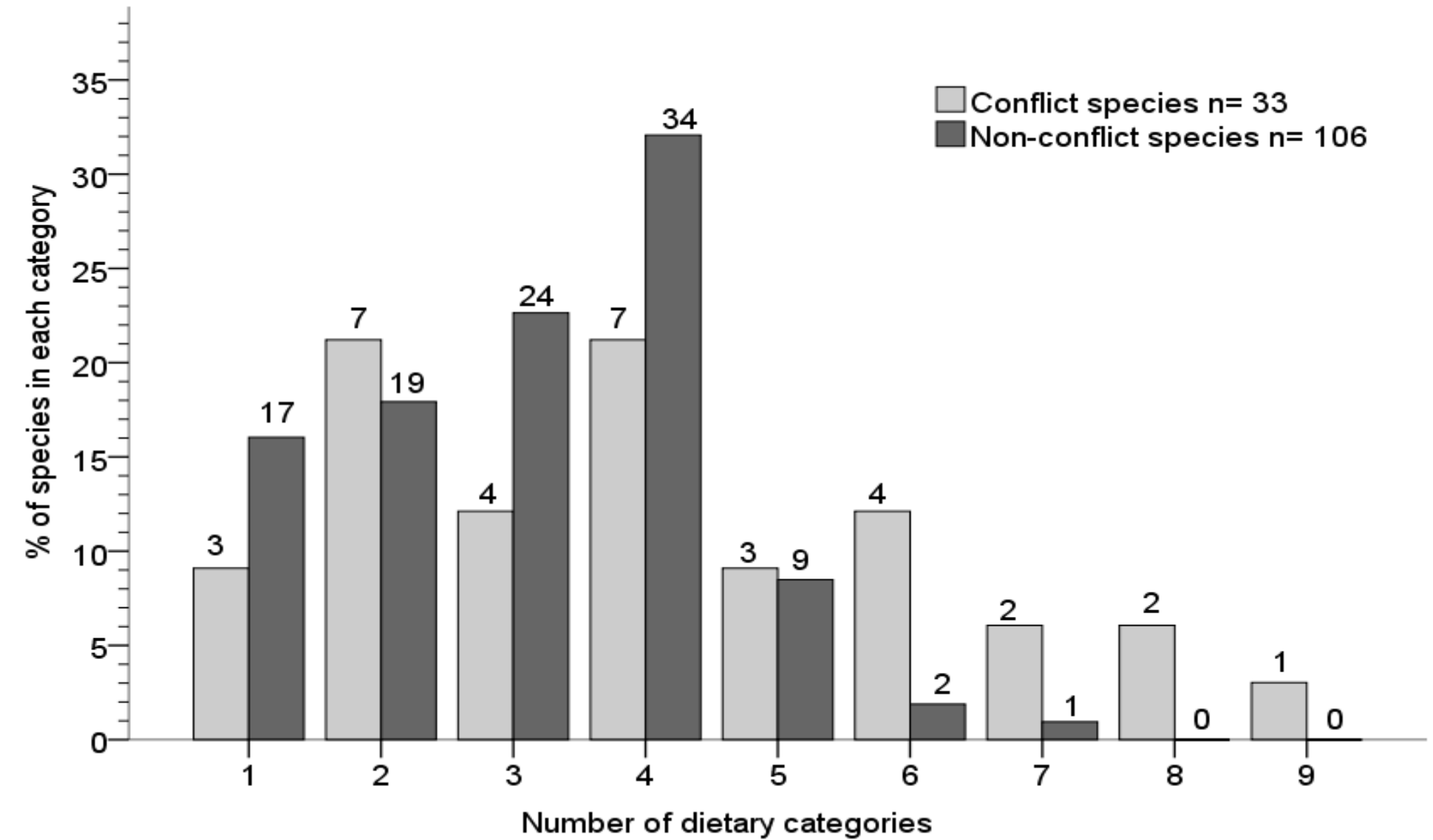

Figure 6.1 Dietary breadth, measured as the number of dietary categories consumed from, for conflict and non-conflict causing species.

Dietary categories were: granivore, folivore, frugivore, nectivore, insectivore, predator (marine invertebrates), predator (vertebrates), piscivore, scavenger. Numbers above each bar are the number of species in each category. 
Table 6.2 List of New Zealand urban bird species and their relative likelihood of generating conflict based on the confidence set of models. Large conflict values indicate a higher likelihood of the species generating conflict in the urban landscape.

\begin{tabular}{|c|c|c|c|c|c|c|c|c|}
\hline Species & & $\begin{array}{l}\text { Diet } \\
\text { breadth }\end{array}$ & Flocking $^{1}$ & $\begin{array}{l}\text { Clutch } \\
\text { Size }\end{array}$ & Grainivory $^{1}$ & Territorial $^{1}$ & $\begin{array}{l}\text { Non-ground } \\
\text { nesting }^{1}\end{array}$ & $\begin{array}{l}\text { Conflict } \\
\text { Value }\end{array}$ \\
\hline Pukeko & Porphyrio porphyrio & 8 & 1 & 4 & 1 & 0 & 0 & 0.09 \\
\hline Red billed gull & Larus scopulinus & 5 & 1 & 2 & 0 & 1 & 1 & -0.04 \\
\hline Kākā & Nestor meridionalis & 5 & 1 & 3.5 & 1 & 0 & 1 & -0.32 \\
\hline Spur-winged plover & Vanellus miles & 4 & 1 & 4 & 1 & 1 & 0 & -0.49 \\
\hline Paradise shelduck & Tadorna variegata & 4 & 0 & 9 & 1 & 0 & 1 & -0.64 \\
\hline Kingfisher & Todiramphus sancta & 4 & 0 & 5 & 0 & 1 & 1 & -0.87 \\
\hline Black shag & Phalacrocorax carbo & 3 & 1 & 3.5 & 0 & 0 & 1 & -1.23 \\
\hline NZ pigeon & Hemiphaga novaseelandiae & 2 & 1 & 1 & 0 & 1 & 1 & -1.28 \\
\hline Bellbird & Anthornis melanura & 3 & 1 & 3 & 0 & 0 & 1 & -1.33 \\
\hline Silvereye & Zosterops lateralis & 3 & 1 & 3 & 0 & 0 & 1 & -1.33 \\
\hline Black-backed gull & Larus dominicanus & 5 & 1 & 3 & 0 & 0 & 0 & -1.36 \\
\hline Black-billed gull & Larus bulleri & 4 & 1 & 2 & 0 & 0 & 0 & -1.91 \\
\hline Welcome swallow & Hirundo neoxena & 1 & 0 & 4.5 & 0 & 1 & 1 & -2.00 \\
\hline Grey warbler & Gerygone igata & 3 & 0 & 3.5 & 1 & 0 & 1 & -2.09 \\
\hline Morepork & Ninox novaseelandae & 2 & 0 & 2 & 0 & 1 & 1 & -2.16 \\
\hline Fantail & Rhipidura fulginosa & 1 & 0 & 3.5 & 0 & 1 & 1 & -2.20 \\
\hline Tui & Prosthermadera novaseelandae & 3 & 0 & 3 & 0 & 0 & 1 & -2.41 \\
\hline Pied oystercatcher & Haematopus ostralegus & 2 & 1 & 2.5 & 0 & 0 & 0 & -2.50 \\
\hline Best Case & & 1 & 0 & 1 & 0 & 0 & 0 & -4.22 \\
\hline Worst Case & & 9 & 1 & 11 & 1 & 1 & 1 & 3.36 \\
\hline
\end{tabular}

${ }^{1}$ Dichotomous variable $(1 / 0=$ presence/absence of the characteristic). 


\subsection{Discussion}

Dietary breadth was found to provide the best explanation for conflict between native bird species and humans in urban landscapes. Species with more generalist diets were more likely to cause conflict than those with more specialised dietary requirements. It is unlikely that dietary breadth itself generates conflict, but it may increase the likelihood of other behaviours and traits generating conflict by allowing birds to reach large population size and high density in the urban environment.

Birds with broad diets have been found to have an advantage over specialist species when colonising the urban landscape (Clergeau et al. 1998; Kark et al. 2007). Highly urbanised areas limit birds with specific dietary needs (Kark et al. 2007) as natural food sources may decrease or become fragmented with increasing urbanisation (Alberti 2008). The ability to utilise novel foods enables birds to exploit new niches provided by the urban landscape and in particular to take advantage of highly available food of anthropogenic origin (Kark et al. 2007) (Moller 2009). Species that have diverse diets may require little adaptation to exploit anthropogenic waste, whereas birds with more specialist diets may not be able to take advantage of this food source. Generalists may also be better able to exploit directly provisioned anthropogenic food such as bread and food scraps.

Species that have the ability to take advantage of anthropogenic food sources may exhibit rapid population growth and may be able to reach population densities far above those found under natural conditions (McKinney 2006). The consistent, virtually unlimited supply of food provided by urban refuse (e.g. landfills, waste bins) and supplementary feeding has been found to influence the distribution of opportunistic bird species (Maciusik et al. 2010; Ryan 2011), to allow urban colonies of birds, such as gulls and ibis, to grow to extraordinary population densities and to lead to population levels exceeding people's 
tolerance (Belant et al. 1998; Martin et al. 2010). Rock (2005) links historical fluctuations in populations of herring (Larus argentatus) and lesser black-backed gulls (Larus fuscus) in the United Kingdom to the availability of waste in landfills, policies against burning of waste, and a botulism outbreak caused by the introduction of black plastic garbage bags. A positive correlation between consumption of waste and fledgling rate in glaucous gulls (Larus hyperboreus) suggests that the ability to exploit this food source may increase recruitment and overall population growth (Weiser \& Powell 2010). Burgeoning urban populations of other bird species, such as the Australian white ibis (Threskiornis molucca, Martin et al. 2010) have also been attributed to diet breadth and food availability. Studies of conflict situations often implicate a species' ability to exploit landfills, other waste sources and intentionally provisioned food as the cause of significant population growth that generates conflict (Belant et al. 1998; Temby 2004; Rock 2005; Martin et al. 2010).

The frequency and severity of a wildlife problem is likely to increase with increased population size and density of the species at fault. There are many examples of conflict situations that have increased along with population growth (Conover \& Chasko 1985; Belant 1997; Pruett-Jones et al. 2007; Martin et al. 2010). Although nest position, breeding and non-breeding sociality, clutch size, body size, diet and habitat type were not found to provide an explanation for conflict in this analysis, these characteristics may generate or exacerbate conflict when combined with large population size and/or high density. Broad diet may not itself cause conflict but instead amplifies the problems caused by cohabitation of birds and humans in urban areas. The level of a problem, such as the amount of faeces or the volume of nesting material transferred to a site, may be proportional to the number of birds in the population. Higher densities concentrate the problem into a smaller area exacerbating the conflict. Furthermore, larger populations are more conspicuous and may increase the salience of the problems being caused, so influencing residents' attitudes towards the conflict situation. Therefore, by influencing a species' ability to take 
advantage of food resources in the urban environment, dietary breadth mediates the degree of impact of other behaviours and traits, by influencing their severity, frequency and level of conspicuousness.

There may be a threshold of damage or disturbance above which an annoyance becomes a conflict. Decker and Purdy (1988) developed the concept of Wildlife Acceptance Capacity (WAC) to describe the maximum wildlife population level in an area that is acceptable to people. Above a certain population level the damage or risk posed by the species will exceed the acceptance threshold and so cause conflict. The level of nuisance or risk that is tolerated varies between communities and across time with numerous individual and social factors. Although developed as a tool to aid in the social dimension of wildlife management, WAC demonstrates the importance of population size and density in generating conflict. Species that can exploit a wide range of food types may be more likely to exceed the level of tolerance due to their ability to reach larger population sizes and densities.

\subsubsection{Case study: New Zealand}

The pukeko was identified as the New Zealand species with the highest relative likelihood of generating conflict. This species has a highly varied diet (del Hoyo et al. 1992), consuming foods from eight of the nine diet categories used in this study. The pukeko causes considerable crop damage in rural areas around the country and is controlled through sport shooting (O'Sullivan 2011). Pukeko are predominantly found near water, particularly swamp and riparian habitats (Craig 1979). With restoration of wetland habitats in or near cities (eg. Morton 2011; Rilkoff 2012), urban populations of this species may increase, which may lead to problems such as garden and ornamental plant damage and traffic hazards.

The red-billed gull is also a potential conflict species in New Zealand. This species has a wide dietary breadth, forms large flocks and may be aggressive. Gulls cause significant conflict in other countries due to nesting and roosting on buildings resulting in complaints due to noise, odour, aggression, fouling and building 
damage (Belant 1997; Rock 2005). Although ranking lower in this analysis, the two other native gull species; the southern black-backed gull (Larus dominicanus) and black-billed gull (Larus bulleri) may also cause problems. All three species have highly varied diets; including marine and terrestrial invertebrates, fish, small reptiles, mammals and refuse (del Hoyo et al. 1992). Despite some studies concerning gulls roosting near airports and the resultant risk of bird strike (Caithness 1968; Chilvers et al. 1997), there have been no published studies of conflicts caused by these species in New Zealand urban areas. Populations of all three species have increased along with urbanization (del Hoyo et al. 1992) and there are reports of black-backed gulls nesting on city buildings (Brockie 1997), a trait that overseas has led to serious conflict situations when combined with high urban population size and density. Urban populations of gulls should be monitored to ensure that significant growth does not occur that could lead to conflict.

The kākā is a threatened parrot, predominantly found on offshore islands or in large tracts of remnant native forest on the mainland. Kākā were reintroduced to the Wellington region in 2002 (Miskelly et al. 2005). When threats such as predation are controlled, the diverse diet and wide repertoire of foraging techniques of the kākā (O'Donnell \& Dilks 1994; Moorhouse 1997) may allow urban population expansion leading to conflict. Kākā in the Wellington region have been observed eating fruit off trees (Chug 2010), causing damage to masonry, timber joinery and cladding and damaging trees by removing large strips of bark (Charles 2012). Resulting tree management costs, property damage and potential loss of valuable amenity and heritage trees is leading to emerging conflict within the city (Charles 2012).

Other species, such as the spur-winged plover (Vanellus miles), paradise shelduck (Tadorna variegata) and black shag (Phalacrocorax carbo), gained a relatively high score in this analysis and have potential to generate conflict. The spurwinged plover causes problems in Australia due to aggressive defence of nesting 
territories (Temby 2004) and similar problems may arise in New Zealand. The paradise shelduck has benefitted from human modification of natural landscapes and has a highly adaptable diet (del Hoyo et al. 1992). This duck is already considered a pest in agricultural areas (del Hoyo et al. 1992) and has the potential to cause problems similar to those generated by ducks such as the mallard (Anas superciliosa) and Pacific black duck (Anas platyrhynchos) such as eutrophication of ponds and lakes, damage to parks and gardens and invasion of backyard swimming pools (Fitzwater 1988; Temby 2004). The black shag has the potential to cause similar conflict to the closely related double-crested cormorant (Phalacrocorax auritus) that has generated significant opposition in the US due to noise, smell and vegetation destruction (Taylor et al. 2011).

\subsubsection{Conclusion}

As this study has shown, emergence of avian-human conflict is linked not just to features of the urban environment, but fundamentally to characteristics of the species themselves. Broad dietary requirements allow for population growth and increased density of a species, amplifying potential problems which may in turn lead to conflict. The limited success of management techniques in reducing established avian conflicts (eg. Conover \& Chasko 1985; Barnes \& Constantin 1993) demonstrates the importance of implementing monitoring and control measures early which may increase the likelihood of successful conflict mitigation. Avian species with broad dietary requirements, particularly those identified in this analysis, should be monitored to detect population growth and problems as they arise in urban areas. Early identification of emerging problems will allow proactive implementation of management strategies increasing the likelihood of successful conflict management. 



\section{Chapter Seven: Discussion}

North Island kākā (Nestor meridionalis septentrionalis: Nestoridae) damage tree bark while foraging for sap on a variety of native and exotic tree species.

Together with other property damage, this is leading to human-kākā and humanhuman conflict about kākā in Wellington City. Sap is likely to be an important resource for both male and female kākā across all life stages and large exotic conifers on exposed ridges and hillsides appear to be favoured for sap foraging. Urban avian-human conflict may increase in New Zealand especially for species with diverse diets such as pukeko (Porphyrio porphyria), red-billed gull (Larus scopulinus), and kākā (Nestor meridionalis). However, residents, particularly those who engage with birds, appear to be tolerant of bird-related problems. This study provides an understanding of the social and biological dimensions of the emerging conflict with kākā in Wellington City and can inform a pre-emptive approach to management that may reduce the negative impacts of damage caused by kākā and foster increased tolerance to problems caused by birds.

\subsection{Study summary}

Kākā forage for sap on a wide range of native and exotic tree species in Wellington City. They appear to favour exotic species for sap foraging, particularly conifers such as macrocarpa (Cupressus macrocarpa) and Lawson cypress (Chamaecyparis lawsoniana). Kākā may favour these species due to their large emergent growth habit or because these species lack physiological adaptations to quickly stem the flow of sap from wounds, resulting in sap flowing faster or for a longer duration. The high numbers of exotic conifer species with damage may also reflect the disproportionate number of these species in the Wellington landscape. Native tree species may have developed strategies to cope with the bark damage and sap loss resulting from kākā sap feeding as no native species were seen with the signs of stress such as epicormic growth or foliage loss and dieback that were observed on many damaged exotic trees. 
Kākā preferentially forage for sap on larger trees, a common preference among sap-feeding species (Pejchar \& Jeffrey 2004; Eyre \& Goldingay 2005; Schlatter \& Vergara 2005). A preference for larger trees may relate to greater hydrostatic pressure in taller trees (Crafts \& Crisp 1971) and therefore greater speed or duration of sap flow, or may reflect the kākā's preference for foraging higher in the canopy.

Kākā also preferentially selected trees that were found on exposed sites. Trees on ridges and hillsides may have greater exposure to sunlight resulting in more concentrated or faster flowing sap. Feeding on trees at these sites may facilitate vocal communication between kākā or reflect a preference for kākā to move between high points across the hilly Wellington landscape.

Previous observations of sap feeding kākā led to the hypothesis that sap feeding is predominantly a female activity providing additional high energy food before breeding (Beaven 1996; Berry 1998). Although no confirmed males were observed foraging for sap, I did not find evidence to suggest that sap feeding is exclusive to females. Individuals estimated to be male as well as juvenile kākā were observed sap feeding. Because the sex of many birds in this study was estimated from fledgling measurements, further study is required to confirm this finding. Nevertheless, sap appears to be a resource utilised by both males and females across adult and juvenile life stages. Therefore, tree damage from sap feeding may also occur in other New Zealand cities where kākā are resident but do not breed or where they are occasional visitors.

The time and energy expended by kākā to access sap and the defence of sap feeding scars from conspecifics and other species suggests that sap is a highly valued resource. Kākā removed tree bark for sap feeding despite access to highquality food at feeding stations within Zealandia-Karori Wildlife Sanctuary and food provisioning by a third of Wellington City residents. This demonstrates that sap feeding is not a response to food limitation and is unlikely to be necessary to meet energy needs. It has previously been suggested that provision of high- 
energy supplementary food may reduce the need for sap feeding and hence reduce bark damage. This study demonstrates that provision of supplementary food is unlikely to be an effective strategy for reducing sap foraging damage.

This study does not clarify why kākā engage in sap feeding. It is possible that sap may contain nutrients not available in other foods or signals for breeding (Beaven 1996; Wilson et al. 1998). Other parrot species such as sulphur-crested cockatoo (Cacatua galerita) and little corella (Cacatua sanguinea) chew wood to assist in beak maintenance (Temby 2004, 2010), and bark removal may have a similar function for kākā. Bark removal may also play a role in beak development for juvenile kākā. These hypotheses could be tested by nutrient analyses of sap and experiments with captive or free-ranging kākā.

Wellington City residents had overwhelmingly positive attitudes towards birds. The vast majority of survey respondents valued and enjoyed seeing native birds and believed that minor problems should be tolerated. This is encouraging as positive attitudes towards wildlife are linked to greater tolerance to wildlife problems and support for species conservation (Kaczensky et al. 2004; Liu et al. 2011). Respondents who had planted trees or plants on their property to encourage birds were most likely to have positive attitudes and were more tolerant of bird problems. Hence, attitude to birds appears to be most closely associated with a person's level of engagement. The experience of bird problems had a minor impact on attitudes to birds, except where it interacted with engagement with birds. Hence people may be willing to tolerate minor problems caused by kākā without these problems having a significant impact on attitudes. It is possible that direct engagement with birds may foster positive attitudes and increase tolerance to bird problems and so encouraging urban residents to engage with birds by attracting them through planting may be an effective way of reducing negative attitudes and increasing tolerance to problems caused by birds. 
Based on the modelling of characteristics of urban avian-conflict species in other countries, kākā were identified as one of the New Zealand bird species most likely to cause conflict in urban landscapes, along with pukeko (Porphyrio porphyria) and red-billed gull (Larus scopulinus). In this analysis, dietary breadth was found to provide the greatest inference for urban avian-human conflict. The ability to utilise a range of food sources, including the ability to exploit foods of anthropogenic origin, may lead to increased population size and density that magnifies the problems caused by birds. The kākā's broad diet and ability to exploit supplementary foods is likely to be a factor in their population growth and increasing distribution in New Zealand cities. Being able to exploit intentionally provisioned food brings kākā into closer contact with people, buildings and other anthropogenic objects increasing the likelihood of problems, particularly due to the bold and investigative behaviour of kākā.

The power of dietary breadth for predicting urban conflict species and the tendency for people to tolerate minor or infrequent problems suggest that the increase in severity of a problem, resulting from a species reaching high population size and density due to a broad diet, may be what exceeds people's level of tolerance. Hence conflicts with wildlife may originate not simply from the occurrence of a problem but its increased magnitude or prevalence, with large and dense populations generating more severe problems and hence more likely to result in conflict. This suggests that two complementary approaches may be effective in managing conflicts with wildlife; reducing the negative impact of wildlife by managing the density of the conflict species and increasing people's level of tolerance to problems. Management strategies that integrate ecological and social dimensions commonly focus on both of these approaches and may be more effective at minimising conflicts (Madden 2004; Jonker et al. 2006). My study has approached the conflict with kākā from both ecological and social angles and identifies management strategies to reduce the negative impacts of kākā sap feeding and potentially increase people's tolerance. 


\subsection{Management of urban wildlife conflict}

Since the majority of people now reside in urban areas and may have limited experiences with wildlife beyond those living in cities (Dunn et al. 2006), it is important that human-wildlife interactions in urban landscapes are generally positive. However, characteristics of the urban landscape such as anthropogenic food, lowered predation rates and high densities of people and wildlife increase the likelihood of people having negative interactions with wildlife. Coupled with increasing social diversity and highly individualised perspectives on wildlife and wildlife management (Patterson et al. 2003), there is an increased likelihood of conflict with wildlife and over wildlife management in cities compared with lesspopulated landscapes. Although there are few conflict species and relatively minor problems being experienced with wildlife currently in New Zealand cities, problems caused by kākā and other avian species identified in this study are likely to increase and result in higher levels of conflict between humans and urban wildlife in the future.

If conflict is not adequately addressed, sustained progress and support for conservation may be lost (Madden 2004). Public support for conservation is especially important in New Zealand where volunteers and community groups make a considerable contribution to biodiversity conservation. Communitybased conservation and restoration groups are numerous (see www.naturespace.org.nz) and supporting community-led conservation is a pivotal part of the Department of Conservation's new approach to biodiversity conservation (Department of Conservation 2012). Managing emerging conflicts with kākā and other urban wildlife is likely to be crucial to ensuring the New Zealand public continues to support and contribute to conservation in the future.

The dynamic and complex nature of human-wildlife interactions means that the complete and sustained resolution of conflicts is rare (Dickman 2010). Instead, management of wildlife conflict is an on-going process of finding equilibrium between the diverse values, perspectives and experiences of people and the resource requirements and conservation of wildlife (Dickman 2010; Decker \& 
Chase 1997). My study makes the first steps in this process by exploring the ecological, behavioural and social aspects of kākā conflict in Wellington City and suggesting ways to manage interactions between kākā and people.

\subsection{Management recommendations}

The considerable breeding success of the Wellington City kākā population has resulted in a high rate of population growth since the initial translocation to Zealandia-Karori Wildlife Sanctuary in 2002. The wide range of exotic trees used for sap feeding in the modified landscape of urban Wellington demonstrates the kākā's ability to alter its foraging strategies in a human-modified landscape. This ability to manage and adapt in the urban landscape, coupled with a strong dispersal ability, and extensive predator control and highly-available food in the Wellington region, means that the kākā population may continue to grow and disperse further. If the population increases, it is likely that more sap foraging will occur, resulting in an increase in bark damage on trees in the Wellington region. It is also likely that other kākā problems, including damage to buildings and other property, loss of fruit and nuts, and noise will also become more prevalent.

As I have shown, sap appears to be an important food resource for both sexes of kākā across all life stages and hence it is unlikely that kākā sap feeding in Wellington City can be reduced. Therefore, management of this conflict should focus on reducing the negative impacts of the bark damage that results from sap feeding. The results of this study suggest a number of possible strategies to reduce the negative impacts of sap feeding and other damage by kākā.

Management of the conflict with kākā in Wellington City should integrate ecological and social approaches to reduce the negative impacts of damage to trees and property and should include some or all of the following:

1. Monitoring potentially hazardous trees with high levels of damage to mitigate risks to people. 
2. Increasing the proportion of damage tolerant species in the landscape by planting species with greater tolerance to bark damage on public and private land.

3. Retaining trees that are favoured by kākā for sap feeding in areas where they pose minimal hazard.

4. Further research into repellent and aversion methods to protect highly valued trees and to discourage property damage.

5. Increasing Wellington City residents' engagement with birds by encouraging the planting of trees and plants to attract birds on private property.

A monitoring plan should be implemented to identify trees in public greenspaces that are heavily damaged and that may pose a risk to public safety. Comprehensive monitoring of trees across all public greenspaces within the kākā's distribution will be costly and time consuming. Monitoring should be focused on the trees most likely to sustain damage and areas where damaged trees may pose a risk to public safety. This study helps guide monitoring by suggesting that it should be targeted towards large conifers, particularly those on exposed sites that are frequented by people.

Long-term management of the impact of kākā sap feeding in urban areas should focus on planting tree species that are less likely to exhibit negative effects of bark damage such as reduced health and structural integrity. Increasing the proportion of tree species that are favoured by kākā for sap feeding yet are more resilient to bark damage may reduce sap feeding on more vulnerable species and so reduce the negative impacts of bark damage which lead to conflict. Further research will be needed to determine the differential tolerance of tree species to bark damage and to identify species that are highly favoured by kākā yet resilient to bark damage. These species can then be recommended for future planting. 
Although this study did not quantify how different tree species are affected by bark damage, subjective assessments of foliage loss and browning suggest that native tree species, such as mahoe, may be more tolerant of bark damage caused by sap foraging. Previous observations of sap feeding damage elsewhere in New Zealand suggest that native species, such as rata (Metrosideros spp.) and tōtara (Podocarpus totara), may be favoured by kākā for sap feeding but not be negatively affected by bark damage (Buller 1888; O'Donnell \& Dilks 1989). Future tree planting on public and private land should focus on planting these species. Species that were found in this study to have negative effects of bark damage should be avoided for future planting, these include exotic cypress and cedar species, such as Lawson cypress and Japanese cedar (Cryptomeria japonica), pine species (Pinus spp.) other than radiata pine, and some Eucalyptus species. Information should be provided to Wellington residents as to the tree species recommended for future planting on private property.

Vegetation management on public land, particularly on the Wellington Town Belt, has the potential to impact on the availability and distribution of trees that kākā target for sap feeding. In order to minimise the negative impacts of bark damage, tree species favoured by kākā for sap feeding should be retained in areas where safety concerns are minimal, such as on steep hillsides away from buildings, roads, walking-paths and mountain bike tracks. Some areas of the Wellington Town Belt are being restored to native vegetation, which in many cases requires the removal of large exotic conifers (Wellington City Council $2012 b)$. This study suggests that large conifers may be a favoured sap resource for kākā and these large trees also provide other resources such seeds and nesting cavities (Wannan 2012). The removal of these trees, before the establishment of native tree species that provide sap resources, may cause kākā to shift sap feeding to where bark damage is likely to have a greater negative impact on people, such as on more valued amenity trees in parks and residential areas. Hence, it may be useful to retain some large conifers, particularly 
macrocarpa, in the Town Belt until alternative resources for sap feeding are available.

Further research should investigate ways to protect particular highly valued specimen trees from future damage from kākā. Aversion or repellent techniques may be effective at dissuading kākā from sap foraging on particular focal trees. Research is currently underway to trial repellent substances for kea. The aim is to determine a practical yet effective surface repellent that will deter kea from attacking sheep, predator control traps and human property (Kea Conservation Trust 2013a). Similar repellents may be able to be used to deter kākā from trees and property. Application of repellents is likely to be resource intensive so this strategy would only be feasible to protect a limited number of highly valued trees, such as those with particular heritage or cultural value. Aversion techniques, such as squirting kākā with water, may be more challenging as they must be consistently applied in order for learning to occur. Despite this, several survey respondents in this study reported using water to deter kākā from trees or buildings. Aversion techniques and repellents may also be useful to protect trees that would pose a risk to safety if damaged, such as those near roads or busy walkways.

Prior research and experience with kea may also be useful in reducing or managing the property damage caused by kākā. Strategies for deterring kea from wiring, vehicles, and vulnerable building materials may have useful applications in Wellington City. For example, heavy duty heat-shrink, conduits and resin have been used successfully to protect wiring and aerials from kea (Kea Conservation Trust 2013a). Removing lead and other toxic metals from the environment will also be important to protect kākā from ingesting and being poisoned by these metals.

Since a substantial reduction in tree damage is unlikely, social techniques to maintain positive attitudes and increase tolerance are likely to be a crucial dimension of managing conflict with kākā. Changing perceptions of wildlife 
interactions and increasing tolerance levels by enhancing peoples appreciation of wildlife can be an effective strategy to reduce conflict with wildlife (Messmer 2009).

Residents who do not engage with urban birds tend to have less positive attitudes that may be more negatively affected by experiencing problems. These residents are the least likely to tolerate problems caused by birds such as kākā. It is possible that encouraging residents to engage and connect with urban birds may increase their appreciation and tolerance for kākā and other birds and so may reduce conflict. Strategies to increase planting on private property may include increased promotion of the ecological and social benefits of planting, improving access to information about species selection, planting techniques and plant care, and identifying and addressing barriers to planting on private property. Although some barriers to planting, such as plant cost, could be reduced, others such as land tenure and a lack of interest and motivation may be more challenging. Engaging with the natural world at a young age has been linked to attitude and support for conservation later in life (Chawla 1999; Wells \& Lekies 2006) and encouraging families and children to plant for birds may be particularly important since problems caused by birds are likely to increase in New Zealand cities in the future.

Residents that currently engage with birds by providing supplementary food could be encouraged to change their engagement activities and instead plant vegetation to attract birds to their properties. Providing natural foraging opportunities for birds may fulfil the same desire to watch, engage with and provide for birds but may be less likely to lead to problems such as high bird densities and property damage that are associated with supplementary food provision.

The Wellington City Council acknowledges the importance of social as well as ecological goals for biodiversity conservation. Social objectives identified in their Biodiversity Strategy include increasing public appreciation and awareness of the 
importance of biodiversity, and motivating, inspiring and educating residents to increase community participation in conservation (Wellington City Council 2007). Encouraging and supporting residents to plant native species on private land in order to attract birds is likely to have wider social and ecological benefits and will complement larger scale urban restoration programs.

Although the kākā population in Wellington City is the only population breeding in an urban area, kākā are increasingly being sighted in many cities around the country (Neems 2009; Carpinter 2010; Healy 2012). Since sap feeding occurs at all life stages and most likely in both sexes, bark damage may occur in other urban areas where kākā are sighted even if they are not resident. Hence, it is likely that the problems experienced in Wellington City will increasingly occur in other cities where kākā are found. By understanding the emerging issues in Wellington City, information about the ecological and social causes of problems and potential management strategies can be used to reduce the negative impacts of urban kākā in other cities. Therefore this research is relevant for kākā conservation and urban biodiversity management across New Zealand.

\subsection{Conclusion}

This thesis has investigated the emerging conflict between North Island kākā and people in Wellington City, with a particular focus on the tree damage caused by kākā while foraging for sap. It is likely that tree and other damage caused by kākā in Wellington City will increase. However, a pre-emptive approach is possible to reduce the negative impacts of damage which may mitigate the emerging conflict between residents and kākā. An integrated understanding of the social and biological dimensions is critical to the successful management of humanwildlife conflicts. This study has integrated ecological, behavioural and social science to understand the emerging conflict with kākā in Wellington City and can be used as a template for future study of urban human-wildlife conflicts, particularly in New Zealand where an integrated approach has not be utilised before. 


\section{Appendix I: Correlation and association matrices}

Al.1 Correlation matrix of variables used in Chapter Three for the analysis of tree selection for sap feeding. Associations between quantitative-quantitative, quantitative-dichotomous and dichotomous-dichotomous variables were measured using Pearson's and point biserial correlation coefficients and phi coefficients respectively. $\mathrm{N}=158$.

\begin{tabular}{|c|c|c|c|c|c|c|c|c|c|c|c|c|}
\hline \multirow[t]{2}{*}{ Disturbance } & Coefficient & $.257^{* *}$ & & & & & & & & & & \\
\hline & Sig. & .001 & & & & & & & & & & \\
\hline \multirow[t]{2}{*}{$\overline{\text { CER }}$} & Coefficient & $.252^{* *}$ & $.364^{* *}$ & & & & & & & & & \\
\hline & Sig. & .001 & .000 & & & & & & & & & \\
\hline \multirow[t]{2}{*}{ Brix } & Coefficient & $-.322^{* *}$ & $-.208^{* *}$ & $-.370^{* *}$ & & & & & & & & \\
\hline & Sig. & .000 & .009 & .000 & & & & & & & & \\
\hline \multirow{2}{*}{$\begin{array}{l}\text { Bark } \\
\text { thickness }\end{array}$} & Coefficient & $.169^{*}$ & -.083 & $.222^{* *}$ & $-.304^{* *}$ & & & & & & & \\
\hline & Sig. & .034 & .299 & .005 & .000 & & & & & & & \\
\hline \multirow[t]{2}{*}{ Bark type $^{1}$} & Coefficient & $.275^{* *}$ & .040 & $.350^{* *}$ & $-.330^{* *}$ & $.498^{* *}$ & & & & & & \\
\hline & Sig. & .000 & .614 & .000 & .000 & .000 & & & & & & \\
\hline \multirow[t]{2}{*}{$\overline{\mathrm{DBH}}$} & Coefficient & $.344^{* *}$ & -.003 & $.261^{* *}$ & $-.340^{* *}$ & $.670^{* *}$ & $.578^{* *}$ & & & & & \\
\hline & Sig. & .000 & .968 & .001 & .000 & .000 & .000 & & & & & \\
\hline \multirow{2}{*}{$\begin{array}{l}\text { Distance to } \\
\text { KWS }\end{array}$} & Coefficient & $-.272^{* *}$ & .047 & -.050 & -.048 & .072 & .038 & .065 & & & & \\
\hline & Sig. & .001 & .557 & .536 & .546 & .367 & .633 & .418 & & & & \\
\hline \multirow[t]{2}{*}{ Height } & Coefficient & $.339^{* *}$ & $.228^{* *}$ & $.262^{* *}$ & $-.491^{* *}$ & $.641^{* *}$ & $.607^{* *}$ & $.816^{* *}$ & $.253^{* *}$ & & & \\
\hline & Sig. & .000 & .004 & .001 & .000 & .000 & .000 & .000 & .001 & & & \\
\hline \multirow[t]{2}{*}{ TOPEX } & Coefficient & .105 & $-.215^{* *}$ & $-.277^{* *}$ & $.177^{*}$ & $-.362^{* *}$ & $-.356^{* *}$ & $-.250^{* *}$ & -.029 & $-.283^{* *}$ & & \\
\hline & Sig. & .188 & .007 & .000 & .026 & .000 & .000 & .002 & .714 & .000 & & \\
\hline \multirow[t]{2}{*}{ Density } & Coefficient & .005 & $.325^{* *}$ & -.043 & .046 & $-.431^{* *}$ & $-.423^{* *}$ & $-.445^{* *}$ & $-.190^{*}$ & $-.373^{* *}$ & .104 & \\
\hline & Sig. & .954 & .000 & .594 & .563 & .000 & .000 & .000 & .017 & .000 & .193 & \\
\hline \multirow[t]{3}{*}{ Aspect $^{1}$} & Coefficient & $-.190^{*}$ & -.020 & .041 & .128 & -.001 & -.048 & $-.219^{* *}$ & $-.535^{* *}$ & $-.324^{* *}$ & $-.257^{* *}$ & $.168^{*}$ \\
\hline & Sig. & .017 & .799 & .611 & .110 & .993 & .550 & .006 & .000 & .000 & .001 & .035 \\
\hline & & $\frac{\stackrel{0}{\frac{0}{3}}}{\stackrel{+}{+}}$ & 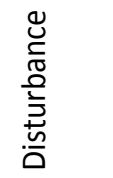 & 邑 & $\stackrel{x}{\frac{x}{\omega}}$ & 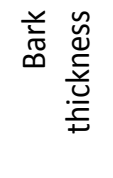 & 竞 & I & 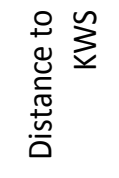 & 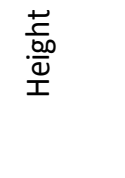 & $\begin{array}{l}\text { 㟧 } \\
\text { 음 }\end{array}$ & $\begin{array}{l}\frac{3}{n} \\
\frac{2}{2} \\
0\end{array}$ \\
\hline
\end{tabular}

\footnotetext{
${ }^{1}$ Dichotomous variable. ${ }^{* *}$ Correlation is significant at the 0.01 level (2-tailed). $*$ Correlation is significant at the 0.05 level ( 2 -tailed).
} 
Al.2 Correlation matrix of variables used in Chapter Five for the analysis of predictors of attitude to birds and bird problems. Correlations between ordinalordinal, ordinal-dichotomous and dichotomous-dichotomous variables were measured using Spearman's rho, rank biserial correlation coefficients and phi coefficients respectively. $\mathrm{N}=594$.

\begin{tabular}{|c|c|c|c|c|c|}
\hline \multirow[t]{2}{*}{ Awareness $^{1}$} & Coefficient & $.182^{* *}$ & & & \\
\hline & Sig. & .001 & & & \\
\hline \multirow[t]{2}{*}{ Feeding $^{2}$} & Coefficient & -.037 & .074 & & \\
\hline & Sig. & .367 & .073 & & \\
\hline \multirow[t]{2}{*}{ Planting $^{2}$} & Coefficient & $.114^{* *}$ & $.148^{* *}$ & $.255^{* *}$ & \\
\hline & Sig. & .005 & .000 & .000 & \\
\hline \multirow[t]{3}{*}{ Problem $^{2}$} & Coefficient & -.047 & .032 & .052 & .031 \\
\hline & Sig. & .257 & .443 & .208 & .453 \\
\hline & & 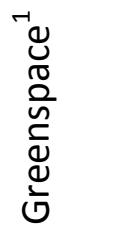 & 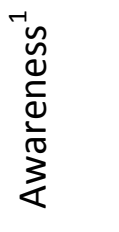 & 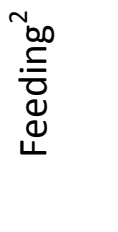 & 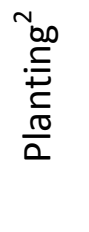 \\
\hline
\end{tabular}

${ }^{1}$ Ordinal variable. ${ }^{2}$ Dichotomous variable.

${ }^{* *}$ Correlation is significant at the 0.01 level (2-tailed). ${ }^{*}$ Correlation is significant at the 0.05 level (2-tailed). 
Al.3 Matrix showing associations between demographic variables and predictor variables used in Chapter Five. Correlation between ordinal variables was measured using Spearman's rho, all other associations were measured using chisquared tests. $\mathrm{N}=594$.

\begin{tabular}{lllll}
\hline & Greenspace $^{2}$ & Awareness $^{2}$ & Feeding $^{1}$ & Planting $^{1}$ \\
\hline \multirow{2}{*}{ Sex $^{1}$} & $\chi^{2}{ }_{4}=4.981$ & $\chi^{2}{ }_{4}=6.279$ & $\chi^{2}{ }_{1}=0.376$ & $\chi^{2}{ }_{1}=0.147$ \\
& $p=.289$ & $p=.179$ & $p=.540$ & $p=.701$ \\
\hline \multirow{2}{*}{ Age $^{2}$} & $r_{s}=-.159^{* *}$ & $r_{s}=-.013$ & $\chi^{2}{ }_{4}=34.952^{* *}$ & $\chi^{2}{ }_{4}=23.639^{* *}$ \\
& $p<.001$ & $p=.748$ & $p<.001$ & $p<.001$ \\
\hline \multirow{2}{*}{ Education $^{2}$} & $r_{s}=.129^{* *}$ & $r_{s}=.135^{* *}$ & $\chi^{2}{ }_{4}=24.011^{* *}$ & $\chi^{2}{ }_{4}=2.094$ \\
& $p=.002$ & $p=.001$ & $p<.001$ & $p=.718$ \\
\hline \multirow{2}{*}{ Income $^{2}$} & $r_{s}=.074$ & $r_{s}=.093^{*}$ & $\chi^{2}{ }_{6}=10.688$ & $\chi^{2}{ }_{6}=4.506$ \\
& $p=.073$ & $p=.024$ & $p=.098$ & $p=.609$ \\
\hline \multirow{2}{*}{ Ethnicity $^{1}$} & $\chi^{2}{ }_{4}=1.618$ & $\chi^{2}{ }_{4}=7.009$ & $\chi^{2}{ }_{1}=0.005$ & $\chi^{2}{ }_{1}=1.192$ \\
& $p=.805$ & $p=.135$ & $p=.946$ & $p=.275$ \\
\hline
\end{tabular}

${ }^{1}$ Dichotomous variable. ${ }^{2}$ Ordinal variable

**significant at the 0.01 level. ${ }^{*}$ significant at the 0.05 level. 
Al.3 Correlation matrix of variables used in Chapter Six for the analysis of characteristics of urban avian-human conflict species. All variables are dichotomous unless otherwise identified. Associations between quantitative-quantitative, quantitative-dichotomous and dichotomous-dichotomous variables were measured using Pearson's and point biserial correlation coefficients and phi coefficients respectively. $\mathrm{N}=139$.

\begin{tabular}{|c|c|c|c|c|c|c|c|c|c|c|c|c|}
\hline Territoriality & $\begin{array}{l}\text { Coefficient } \\
\text { Sig. }\end{array}$ & $\begin{array}{l}-.161 \\
.058\end{array}$ & & & & & & & & & & \\
\hline \multirow[t]{2}{*}{ Grainivory } & Coefficient & -.160 & -.152 & & & & & & & & & \\
\hline & Sig. & .059 & .074 & & & & & & & & & \\
\hline \multirow[t]{2}{*}{ Diet Breadth $^{1}$} & Coefficient & $.319^{* *}$ & -.092 & $.332^{* *}$ & & & & & & & & \\
\hline & Sig. & .000 & .280 & .000 & & & & & & & & \\
\hline Colonial & Coefficient & $.383^{* *}$ & -.159 & $-.219^{* *}$ & $.262^{* *}$ & & & & & & & \\
\hline Nesting & Sig. & .000 & .062 & .010 & .002 & & & & & & & \\
\hline \multirow[t]{2}{*}{ Flocking } & Coefficient & -.033 & $-.240^{* *}$ & .032 & .129 & $.259^{* *}$ & & & & & & \\
\hline & Sig. & .696 & .004 & .712 & .131 & .002 & & & & & & \\
\hline \multirow[t]{2}{*}{ Tree Nesting } & Coefficient & .036 & $.215^{*}$ & -.039 & $.201^{*}$ & -.060 & -.105 & & & & & \\
\hline & Sig. & .675 & .011 & .649 & .017 & .483 & .218 & & & & & \\
\hline Tree or Cliff & Coefficient & .050 & .146 & $-.201^{*}$ & .077 & .021 & -.123 & $.805^{* *}$ & & & & \\
\hline Nesting & Sig. & .557 & .087 & .018 & .366 & .809 & .150 & .000 & & & & \\
\hline \multirow[t]{2}{*}{ Cavity Nesting } & Coefficient & $-.254^{* *}$ & $-.237^{* *}$ & .091 & $-.300^{* *}$ & $-.239^{* *}$ & .062 & $-.336^{* *}$ & $-.289^{* *}$ & & & \\
\hline & Sig. & .003 & .005 & .288 & .000 & .005 & .472 & .000 & .001 & & & \\
\hline Non-ground & Coefficient & -.062 & .013 & -.106 & -.075 & -.109 & -.114 & $.643^{* *}$ & $.799^{* *}$ & $.285^{* *}$ & & \\
\hline Nesting & Sig. & .472 & .876 & .214 & .379 & .203 & .181 & .000 & .000 & .001 & & \\
\hline \multirow[t]{2}{*}{ Built Nests } & Coefficient & -.078 & .046 & $-.208^{*}$ & .039 & .069 & .094 & $.269^{* *}$ & $.334^{* *}$ & $-.200^{*}$ & $.187^{*}$ & \\
\hline & Sig. & .363 & .589 & .014 & .651 & .415 & .266 & .002 & .000 & .019 & .028 & \\
\hline \multirow[t]{3}{*}{ Clutch Size $^{1}$} & Coefficient & .105 & .086 & $.181^{*}$ & .077 & $-.197^{*}$ & $-.171^{*}$ & -.143 & -.159 & -.074 & $-.214^{*}$ & .145 \\
\hline & Sig. & .219 & .313 & .033 & .369 & .020 & .044 & .093 & .061 & .387 & .012 & .090 \\
\hline & & $\begin{array}{l}\text { in } \\
\text { in } \\
\text { in } \\
\text { Oे } \\
0\end{array}$ & 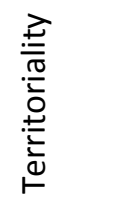 & $\begin{array}{l}\frac{2}{0} \\
\stackrel{2}{\frac{1}{\pi}} \\
\frac{\pi}{0}\end{array}$ & 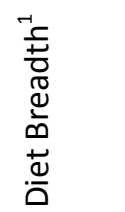 & 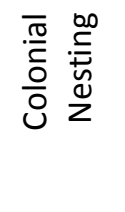 & 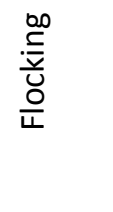 & 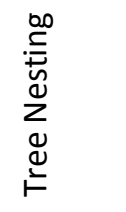 & 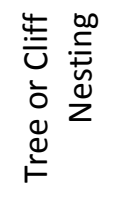 & 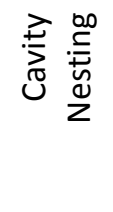 & 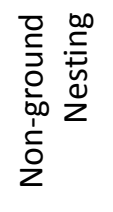 & 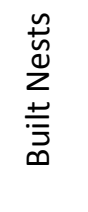 \\
\hline
\end{tabular}

${ }^{1}$ Quantitative variable. ${ }^{* *}$ significant at the 0.01 level (2-tailed). ${ }^{*}$ significant at the 0.05 level (2-tailed). 


\section{Appendix II: Candidate model set for model averaging}

Suite of 93 candidate models used for model averaging in the analysis from Chapter Three of characteristics associated with tree damage. Models are presented in descending order of second-order Akaike Information Criterion (AICC). Presence of a variable in the model is indicated by a $1 .{ }^{\text {A }}$ No. of estimating parameters in candidate model.

\begin{tabular}{|c|c|c|c|c|c|c|c|c|c|c|c|c|}
\hline $\begin{array}{l}\text { Model } \\
\text { No. }\end{array}$ & DBH & $\begin{array}{l}\text { Bark } \\
\text { thickness }\end{array}$ & Solute & Altitude & TOPEX & $\begin{array}{l}\text { Distance to } \\
\text { sanctuary }\end{array}$ & Disturbance & Aspect & $K^{A}$ & $\mathrm{AICC}$ & $\triangle \mathrm{AICC}$ & $\omega_{i}$ \\
\hline 44 & 1 & & 1 & & 1 & & & & 5 & 156.395 & 0.000 & 0.231 \\
\hline 54 & 1 & & & & 1 & & & 1 & 5 & 156.895 & 0.500 & 0.180 \\
\hline 47 & 1 & & 1 & & & & & 1 & 5 & 158.595 & 2.200 & 0.077 \\
\hline 12 & 1 & & & & 1 & & & & 4 & 158.761 & 2.367 & 0.071 \\
\hline 52 & 1 & & & & 1 & 1 & & & 5 & 158.795 & 2.400 & 0.070 \\
\hline 39 & 1 & 1 & & & 1 & & & & 5 & 159.195 & 2.800 & 0.057 \\
\hline 59 & & 1 & 1 & & 1 & & & & 5 & 159.395 & 3.000 & 0.052 \\
\hline 62 & & 1 & 1 & & & & & 1 & 5 & 160.595 & 4.200 & 0.028 \\
\hline 37 & 1 & 1 & 1 & & & & & & 5 & 160.695 & 4.300 & 0.027 \\
\hline 48 & 1 & & & 1 & 1 & & & & 5 & 160.895 & 4.500 & 0.024 \\
\hline 53 & 1 & & & & 1 & & 1 & & 5 & 160.895 & 4.500 & 0.024 \\
\hline 42 & 1 & 1 & & & & & & 1 & 5 & 161.195 & 4.800 & 0.021 \\
\hline 15 & 1 & & & & & & & 1 & 4 & 161.861 & 5.467 & 0.015 \\
\hline 10 & 1 & & 1 & & & & & & 4 & 162.161 & 5.767 & 0.013 \\
\hline 16 & & 1 & 1 & & & & & & 4 & 162.861 & 6.467 & 0.009 \\
\hline
\end{tabular}




\begin{tabular}{|c|c|c|c|c|c|c|c|c|c|c|c|c|}
\hline 69 & & 1 & & & 1 & & & 1 & 5 & 162.995 & 6.600 & 0.009 \\
\hline 18 & & 1 & & & 1 & & & & 4 & 163.561 & 7.167 & 0.006 \\
\hline 43 & 1 & & 1 & 1 & & & & & 5 & 163.595 & 7.200 & 0.006 \\
\hline 45 & 1 & & 1 & & & 1 & & & 5 & 163.695 & 7.300 & 0.006 \\
\hline 51 & 1 & & & 1 & & & & 1 & 5 & 163.795 & 7.400 & 0.006 \\
\hline 56 & 1 & & & & & 1 & & 1 & 5 & 163.995 & 7.600 & 0.005 \\
\hline 57 & 1 & & & & & & 1 & 1 & 5 & 163.995 & 7.600 & 0.005 \\
\hline 60 & & 1 & 1 & & & 1 & & & 5 & 163.995 & 7.600 & 0.005 \\
\hline 46 & 1 & & 1 & & & & 1 & & 5 & 164.295 & 7.900 & 0.004 \\
\hline 9 & 1 & 1 & & & & & & & 4 & 164.361 & 7.967 & 0.004 \\
\hline 67 & & 1 & & & 1 & 1 & & & 5 & 164.395 & 8.000 & 0.004 \\
\hline 58 & & 1 & 1 & 1 & & & & & 5 & 164.895 & 8.500 & 0.003 \\
\hline 61 & & 1 & 1 & & & & 1 & & 5 & 164.995 & 8.600 & 0.003 \\
\hline 40 & 1 & 1 & & & & 1 & & & 5 & 165.195 & 8.800 & 0.003 \\
\hline 63 & & 1 & & 1 & 1 & & & & 5 & 165.395 & 9.000 & 0.003 \\
\hline 79 & & & 1 & & 1 & & & 1 & 5 & 165.395 & 9.000 & 0.003 \\
\hline 68 & & 1 & & & 1 & & 1 & & 5 & 165.695 & 9.300 & 0.002 \\
\hline 1 & 1 & & & & & & & & 3 & 165.756 & 9.361 & 0.002 \\
\hline 21 & & 1 & & & & & & 1 & 4 & 165.761 & 9.367 & 0.002 \\
\hline 23 & & & 1 & & 1 & & & & 4 & 165.861 & 9.467 & 0.002 \\
\hline 41 & 1 & 1 & & & & & 1 & & 5 & 166.195 & 9.800 & 0.002 \\
\hline 38 & 1 & 1 & & 1 & & & & & 5 & 166.395 & 10.000 & 0.002 \\
\hline 78 & & & 1 & & 1 & & 1 & & 5 & 167.295 & 10.900 & 0.001 \\
\hline 13 & 1 & & & & & 1 & & & 4 & 167.361 & 10.967 & 0.001 \\
\hline 26 & & & 1 & & & & & 1 & 4 & 167.561 & 11.167 & 0.001 \\
\hline 77 & & & 1 & & 1 & 1 & & & 5 & 167.695 & 11.300 & 0.001 \\
\hline
\end{tabular}




\begin{tabular}{|c|c|c|c|c|c|c|c|c|c|c|c|}
\hline 11 & 1 & & 1 & & & & & 4 & 167.761 & 11.367 & 0.001 \\
\hline 71 & 1 & & & & 1 & & 1 & 5 & 167.795 & 11.400 & 0.001 \\
\hline 72 & 1 & & & & & 1 & 1 & 5 & 167.795 & 11.400 & 0.001 \\
\hline 14 & 1 & & & & & 1 & & 4 & 167.861 & 11.467 & 0.001 \\
\hline 66 & 1 & & 1 & & & & 1 & 5 & 167.895 & 11.500 & 0.001 \\
\hline 73 & & 1 & 1 & 1 & & & & 5 & 167.995 & 11.600 & 0.001 \\
\hline 2 & 1 & & & & & & & 3 & 168.156 & 11.761 & 0.001 \\
\hline 49 & 1 & & 1 & & 1 & & & 5 & 168.995 & 12.600 & 0.000 \\
\hline 81 & & 1 & & & 1 & & 1 & 5 & 169.295 & 12.900 & 0.000 \\
\hline 55 & 1 & & & & 1 & 1 & & 5 & 169.395 & 13.000 & 0.000 \\
\hline 76 & & 1 & 1 & & & & 1 & 5 & 169.395 & 13.000 & 0.000 \\
\hline 19 & 1 & & & & 1 & & & 4 & 169.561 & 13.167 & 0.000 \\
\hline 82 & & 1 & & & & 1 & 1 & 5 & 169.595 & 13.200 & 0.000 \\
\hline 50 & 1 & & 1 & & & 1 & & 5 & 169.695 & 13.300 & 0.000 \\
\hline 33 & & & & 1 & & & 1 & 4 & 169.761 & 13.367 & 0.000 \\
\hline 20 & 1 & & & & & 1 & & 4 & 170.161 & 13.767 & 0.000 \\
\hline 17 & 1 & & 1 & & & & & 4 & 170.261 & 13.867 & 0.000 \\
\hline 5 & & & & 1 & & & & 3 & 170.656 & 14.261 & 0.000 \\
\hline 3 & & 1 & & & & & & 3 & 170.956 & 14.561 & 0.000 \\
\hline 70 & 1 & & & & 1 & 1 & & 5 & 171.395 & 15.000 & 0.000 \\
\hline 64 & 1 & & 1 & & 1 & & & 5 & 171.695 & 15.300 & 0.000 \\
\hline 90 & & & & 1 & 1 & & 1 & 5 & 171.695 & 15.300 & 0.000 \\
\hline 91 & & & & 1 & & 1 & 1 & 5 & 171.695 & 15.300 & 0.000 \\
\hline 85 & & & 1 & 1 & & & 1 & 5 & 171.895 & 15.500 & 0.000 \\
\hline 65 & 1 & & 1 & & & 1 & & 5 & 172.295 & 15.900 & 0.000 \\
\hline 31 & & & & 1 & 1 & & & 4 & 172.561 & 16.167 & 0.000 \\
\hline
\end{tabular}




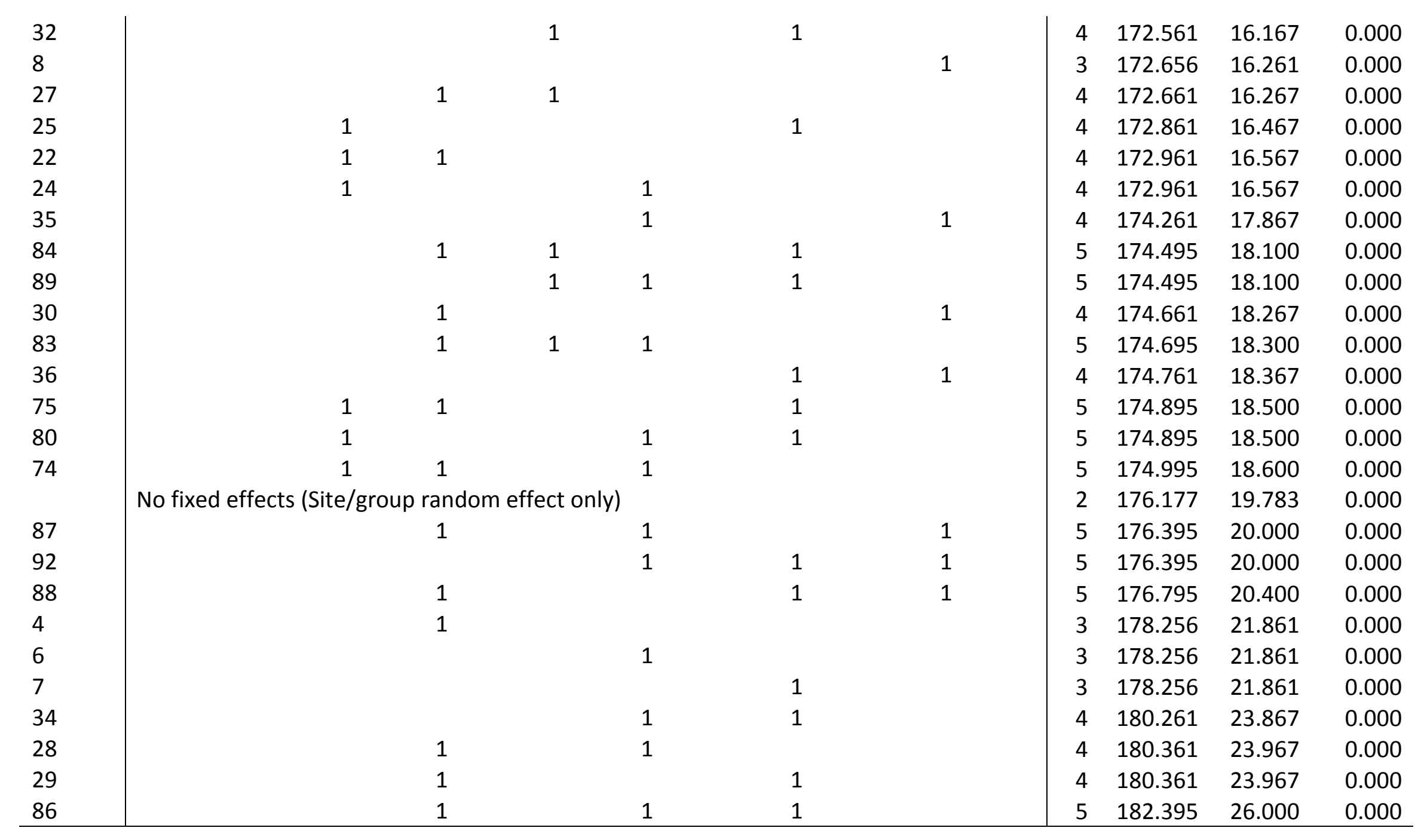




\section{Appendix III: Questionnaire}

The following pages contain copies of the questionnaire and the three associated information letters distributed for the household survey described in Chapter Five. 


\section{VICTORIA UNIVERSITY OF WELLINGTON \\ Te Whare Wānanga o te Ūpoko o te Ika a Māui}

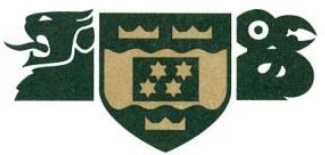

MSc Research Project:

"Residents' Relationship with Birds in Wellington"

30 April 2012

Dear Householder,

About a week from now you will receive in the mail a request to fill out a brief questionnaire for an important research project being conducted at Victoria University of Wellington.

The purpose of this 10 minute questionnaire is to investigate the relationship between residents and birds in Wellington city. Your household has been chosen to due to its geographic location as representative of people living in Wellington city.

I am writing in advance because many people like to know ahead of time that they will receive the survey. Your answers on the questionnaire are confidential and anonymous. The results of the questionnaire will only be used for our study. Once the study is complete, a report will be made available for you on the Victoria University website.

Thank you for your time and consideration with this important research. It's only with the generous help of people like you that our research can be successful.

Sincerely,

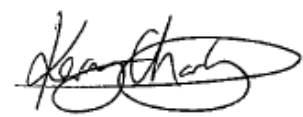

Kerry Charles

MSc Student, Centre for Biodiversity and Restoration Ecology, Victoria University of Wellington Email: Kerry.Charles@ vuw.ac.nz Phone: 044635233 extn 8126

Supervisor: Dr Wayne Linklater

Senior Lecturer, Centre for Biodiversity and Restoration Ecology, Victoria University of Wellington http://www.victoria.ac.nz/sbs/staff/staff_academic/linklaterwayne/linklaterwayne.aspx

\section{SCHOOL OF BIOLOGICAL SCIENCES}

Te Kura Mātauranga Koiora

FACULTY OF SCIENCE

Te Wāhanga Pūtaiao

P.O. Box 600, Wellington, New Zealand

Telephone +64-4-463-5339, Facsimile +64-4-463-5331

Email Biosci@vuw.ac.nz 


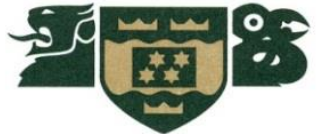

\section{Participant Information Sheet}

\section{MSc Research Project: \\ "Residents' Relationship with Birds in Wellington"}

7 May 2012

Dear Householder,

I am writing to ask your help in a study being conducted to investigate the relationship between people and wild birds in Wellington city. Results from this study will help better understand peoples' experiences with and attitudes towards birds and may contribute to city planning.

Your household has been chosen from houses within Wellington city. I am inviting you to participate in a questionnaire that will not exceed 10 minutes in length.

The information on the questionnaire is anonymous; you will not be asked your name or other sensitive information. You are provided with a postage-paid return envelope so that you can send the completed questionnaire in anonymously.

This research has been approved by the Victoria University Ethics Committee. The results of the questionnaire will only be used for this study and will form the basis of my masters thesis research. The thesis will be submitted for marking to the School of Biological Sciences and deposited in the University Library. It is intended that one or more articles will be submitted for publication in scholarly journals. All material collected will be kept confidential and questionnaires will be destroyed five years after the end of the project. If you change your mind about participating, you can withdraw your responses from the study for up to one month after returning your questionnaire. Once the study is complete, a report will be made available on the Victoria University website.

This survey is voluntary. However, I hope you will take a few minutes to help our research by filling in the questionnaire.

If you have any other questions about this project, please feel free to contact me using the contact details provided below.

Thank you very much for helping with this important study!

Sincerely,

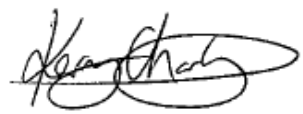

Kerry Charles

MSc Student, Centre for Biodiversity and Restoration Ecology, Victoria University of Wellington

Email: Kerry.Charles@vuw.ac.nz Phone: 044635233 extn 8126

Supervisor: Dr Wayne Linklater

Senior Lecturer, Centre for Biodiversity and Restoration Ecology, Victoria University of Wellington

Email: Wayne.Linklater@vuw.ac.nz Phone: 044635233 extn 8575 


\section{Survey of Residents' Relationship with Birds in Wellington}

\section{Please Start Here}

1. Do you put food or water out for birds?

$\square$ Yes $\longrightarrow$ No
$\square$ If yes, what bird species do you feed or water most?

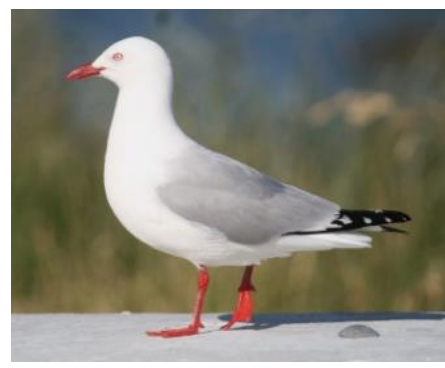

2. In the past year, how often did you visit a green space (park, reserve or public garden)?
$\square$ Not at all
$\square$ Once or twice a year
$\square$ About once a month
$\square$ Two to three times a month
$\square$ Two to three times a week

3. To what extent do you agree or disagree with the following statements: Circle a number for each statement

\begin{tabular}{|c|c|c|c|c|c|}
\hline & $\begin{array}{l}\text { Strongly } \\
\text { Agree }\end{array}$ & & $\begin{array}{l}\text { Neither agree } \\
\text { Nor disagree }\end{array}$ & & $\begin{array}{l}\text { Strongly } \\
\text { Disagree }\end{array}$ \\
\hline Native birds are an asset for our city & 1 & 2 & 3 & 4 & 5 \\
\hline $\begin{array}{l}\text { I enjoy seeing and/or hearing native birds in my } \\
\text { neighbourhood }\end{array}$ & 1 & 2 & 3 & 4 & 5 \\
\hline $\begin{array}{l}\text { Native wildlife has a right to live in our cities, regardless } \\
\text { of problems they may cause }\end{array}$ & 1 & 2 & 3 & 4 & 5 \\
\hline $\begin{array}{l}\text { I would like to see an increase in native birds in my } \\
\text { neighbourhood }\end{array}$ & 1 & 2 & 3 & 4 & 5 \\
\hline Native wildlife species deserve to be protected & 1 & 2 & 3 & 4 & 5 \\
\hline $\begin{array}{l}\text { People should tolerate inconveniences and minor } \\
\text { damage caused by native wildlife }\end{array}$ & 1 & 2 & 3 & 4 & 5 \\
\hline $\begin{array}{l}\text { Non-native birds should be managed if they cause } \\
\text { problems or are overabundant }\end{array}$ & 1 & 2 & 3 & 4 & 5 \\
\hline $\begin{array}{l}\text { Native birds should be managed if they cause problems } \\
\text { or are overabundant }\end{array}$ & 1 & 2 & 3 & 4 & 5 \\
\hline
\end{tabular}

4. Write the name of the bird species pictured* in the blank spaces provided, or tick the 'don't know' box if unsure.

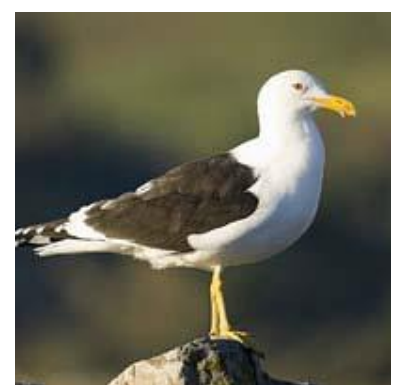

Bird 1

$\square$ Don't know

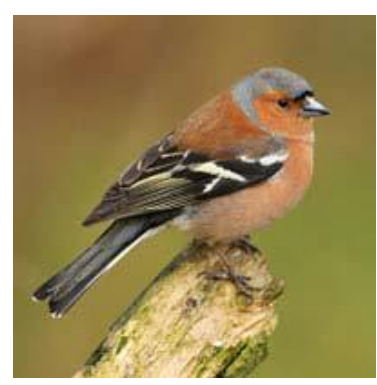

Bird 5

Don't know

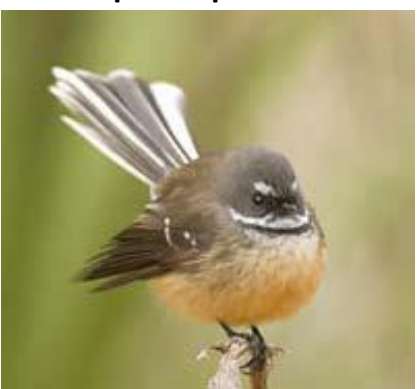

Bird 2

Don't know

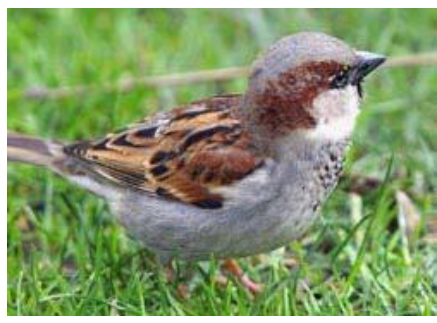

Bird 6

Don't know

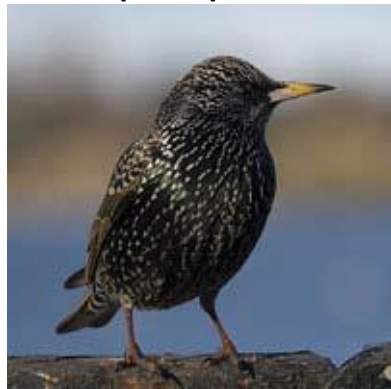

Bird 3

Don't know

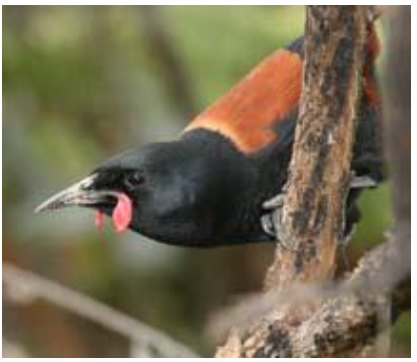

Bird 7

Don't know

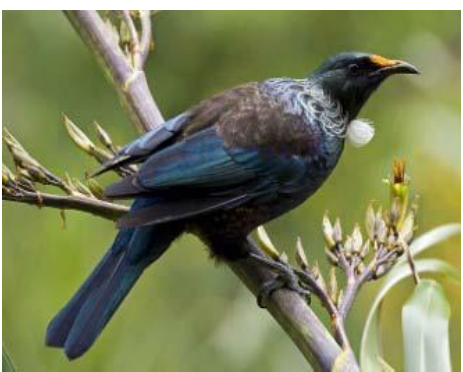

Bird 4

Don't know

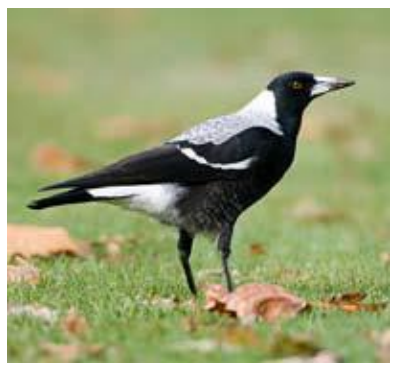

Bird 8

Don't know

Please turn the page 
What do you think are the three greatest threats to native plants and animals in New Zealand?

i. ii. iii.

5. At your home:

Which of these activities have you done in the last month?

Yes

No

Composting organic waste

Kerbside recycling

Which of these activities have you done in the last year?

Donated to an environmental charity

Volunteered for an environmental organisation

Attended a public meeting in support of the environment

Signed a petition in support of the environment

Planted trees or plants to encourage bird life on your property

6. Do native or introduced birds cause any problems on your property?
$\square$ None at all
Go to question 10
$\square$ Only minor problems
$\square$ Moderate problems
$\square$ Fairly serious problems
$\square$ Very severe problems

7. List the problems you experience and the species you think cause each problem Problem

Species

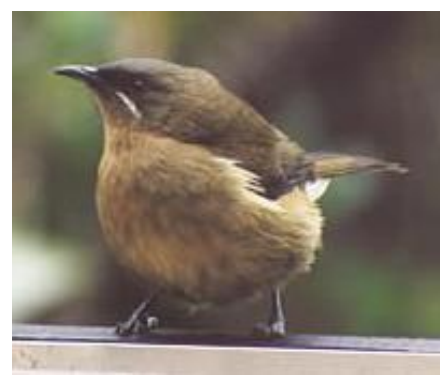

8. Have you taken any action to deal with bird problems on your property? If yes, what is the estimated cost (\$) of these actions?

9. Are you:

$\square$ Female $\square$ Male

10. Please tick the age group you belong to:
$\square 18-25$
$26-35$
$36-50$
$51-70$
Over 70

11. What is your highest educational level?
$\square$ No formal qualifications
$\square$ High school qualification
$\square$ Vocational or Trade qualification
$\square$ Bachelor degree
Postgraduate degree

12. Which describes your annual personal income before tax?

$$
\begin{aligned}
& \square \text { Less than } \$ 10,000 \\
& \square \$ 10,001-30,000 \\
& \square \$ 30,001-50,000 \\
& \square \$ 50,001-70,000 \\
& \square \$ 70,001-100,000 \\
& \square \$ 100,000 \text { or more }
\end{aligned}
$$

13. Which ethnic group do you belong to?
$\square$ New Zealand European
$\square$ Maori
Pacific Islander
Asian
Other. Please specify

Thank you for your help. Return of the survey implies you have consented to participate in this study. You will receive a letter reminding you to return the survey. If you have already returned the survey, please ignore this letter. Surveys can be returned in the envelope provided, or send to: FreePost Bird Study, School of Biological Sciences, Victoria University of Wellington, PO Box 600, Wellington 6140 


\title{
VICTORIA UNIVERSITY OF WELLINGTON \\ Te Whare Wānanga o te Ūpoko o te Ika a Māui
}

\section{0 \\ MSc Research Project: \\ "Residents' Relationship with Birds in Wellington"}

16 May 2012

Dear Householder,

Recently a short questionnaire about birds in the city was mailed to you. Your household was chosen due to its important location and being representative of city residents. As such your participation in this survey is an important addition to the questionnaires also received from your neighbors.

If you have already completed and returned the questionnaire, please accept our sincere thanks. If not, it would be much appreciated if you could complete and return your survey in the postagepaid envelope provided. If you have misplaced your survey, please contact me using the contact details provided below and I will provide a replacement copy.

Alternatively, you can complete the survey online. Go to: www.surveymonkey.com/s/BVN53TP . The hard copy and online surveys are identical, please only complete one or the other.

I'm especially grateful for your help because it is only by asking people like you to share your opinions and experience that we can understand how people in Wellington interact with birds and the value and problems of wildlife in cities. The study is an important one because it will provide information to help improve the relationship between birds and residents in our city.

Thank you very much for helping with this important study!

Sincerely,

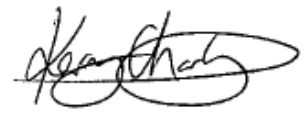

Kerry Charles

MSc Student, Centre for Biodiversity and Restoration Ecology, Victoria University of Wellington Email: Kerry.Charles@vuw.ac.nz Phone: 044635233 extn 8126

Supervisor: Dr Wayne Linklater

Senior Lecturer, Centre for Biodiversity andRestoration Ecology, Victoria University of Wellington http://www.victoria.ac.nz/sbs/staff/staff academic/linklaterwayne/linklater-wayne.aspx

\author{
SCHOOL OF BIOLOGICAL SCIENCES \\ Te Kura Mātauranga Koiora \\ FACULTY OF SCIENCE \\ Te Wāhanga Pūtaiao \\ P.O. Box 600, Wellington, New Zealand \\ Telephone +64-4-463-5339, Facsimile +64-4-463-5331 \\ Email Biosci@vuw.ac.nz
}




\section{Appendix IV: Candidate model set for demographic analysis}

Candidate model set for the demographic analysis used in Chapter Five. All possible combinations of each of the six demographic variables are included in the set. Models are in descending order of Akaike Information Criterion (AIC).

\begin{tabular}{llccc}
\hline Predictors & $\mathrm{K}^{\mathrm{A}}$ & $\mathrm{AIC}$ & $\Delta \mathrm{AIC}$ & $\omega_{i}$ \\
\hline Age & 2 & 690.1 & 0.000 & 0.099 \\
Age + Ethnicity & 3 & 690.3 & 0.200 & 0.090 \\
Ethnicity & 2 & 690.6 & 0.500 & 0.077 \\
Income & 2 & 691.0 & 0.900 & 0.063 \\
Age + Income & 3 & 691.3 & 1.200 & 0.054 \\
Age + Income + Ethnicity & 4 & 691.5 & 1.400 & 0.049 \\
Income + Ethnicity & 3 & 691.5 & 1.400 & 0.049 \\
Age + Education & 3 & 691.9 & 1.800 & 0.040 \\
Sex + Age & 3 & 692.1 & 2.000 & 0.037 \\
Sex & 2 & 692.1 & 2.000 & 0.037 \\
Education & 2 & 692.1 & 2.000 & 0.037 \\
Age + Education + Ethnicity & 4 & 692.2 & 2.100 & 0.035 \\
Sex + Age + Ethnicity & 4 & 692.3 & 2.200 & 0.033 \\
Sex + Ethnicity & 3 & 692.6 & 2.500 & 0.028 \\
Education + Ethnicity & 3 & 692.6 & 2.500 & 0.028 \\
Sex + Income & 3 & 693.0 & 2.900 & 0.023 \\
Education + Income & 3 & 693.0 & 2.900 & 0.023 \\
Sex + Age + Income & 4 & 693.2 & 3.100 & 0.021 \\
Age + Education + Income & 4 & 693.2 & 3.100 & 0.021 \\
Sex + Age + Income + Ethnicity & 5 & 693.5 & 3.400 & 0.018 \\
Age + Education + Income + Ethnicity & 5 & 693.5 & 3.400 & 0.018 \\
Sex + Income + Ethnicity & 4 & 693.5 & 3.400 & 0.018 \\
Education + Income + Ethnicity & 4 & 693.5 & 3.400 & 0.018 \\
Sex + Age + Education & 4 & 693.9 & 3.800 & 0.015 \\
Sex + Education & 3 & 694.0 & 3.900 & 0.014 \\
Sex + Age + Education + Ethnicity & 5 & 694.2 & 4.100 & 0.013 \\
Sex + Education + Ethnicity & 4 & 694.6 & 4.500 & 0.010 \\
Sex + Education + Income & 4 & 695.0 & 4.900 & 0.009 \\
Sex + Age + Education + Income & 5 & 695.2 & 5.100 & 0.008 \\
Sex + Age + Education + Income + & 6 & 695.5 & 5.400 & 0.007 \\
Ethnicity & 5 & 695.5 & 5.400 & 0.007 \\
Sex + Education + Income + Ethnicity & 5 & &
\end{tabular}

${ }^{\mathrm{A}}$ Number of estimating parameters in the model 


\section{Appendix V: Species list for conflict analysis}

Conflict species and non-conflict congeners used in the analysis in Chapter Six. Citations refer to studies used to identify the species as involved in an urban conflict situation.

\begin{tabular}{|c|c|c|c|c|}
\hline \multicolumn{3}{|l|}{ Conflict species } & \multicolumn{2}{|l|}{ Non-conflict species } \\
\hline Red-winged blackbird & Agelaius phoeniceus & (Fitzwater 1988) & $\begin{array}{l}\text { Tricoloured blackbird } \\
\text { Red-shouldered blackbird } \\
\text { Tawny-shouldered blackbird } \\
\text { Yellow-shouldered blackbird }\end{array}$ & $\begin{array}{l}\text { Agelaius tricolour } \\
\text { Agelaius assimlis } \\
\text { Agelaius humeralis } \\
\text { Agelaius xanthomus }\end{array}$ \\
\hline Pacific black duck & Anas superciliosa & (Temby 2004) & American black duck & Anas rubripes \\
\hline Mallard & Anas platyrhynchos & (Fitzwater 1988) & $\begin{array}{l}\text { Blue-winged teal } \\
\text { Grey teal } \\
\text { Red shoveler } \\
\text { Yellow-billed pintail } \\
\text { Cape teal } \\
\text { Spot-billed duck } \\
\text { Northern shoveler }\end{array}$ & $\begin{array}{l}\text { Anas discors } \\
\text { Anas gibberifrons } \\
\text { Anas platalea } \\
\text { Anas georgica } \\
\text { Anas capensis } \\
\text { Anas poecilorhyncha } \\
\text { Anas clypeata }\end{array}$ \\
\hline Canada goose & Branta canadensis & $\begin{array}{l}\text { (Conover \& } \\
\text { Chasko 1985) }\end{array}$ & $\begin{array}{l}\text { Barnacle goose } \\
\text { Red-breasted goose } \\
\text { Brent goose } \\
\text { Hawaiian goose }\end{array}$ & $\begin{array}{l}\text { Branta leucopsis } \\
\text { Branta ruficollis } \\
\text { Branta bernicla } \\
\text { Branta sandvicensis }\end{array}$ \\
\hline Sulphur-crested cockatoo & Cacatua galerita & (Temby 2004) & Major Mitchell's cockatoo & Cacatua leadbeateri \\
\hline
\end{tabular}




\begin{tabular}{|c|c|c|c|c|}
\hline $\begin{array}{l}\text { Long-billed corella } \\
\text { Little corella }\end{array}$ & $\begin{array}{l}\text { Cacatua tenuirostris } \\
\text { Cacatua sanguinea }\end{array}$ & & $\begin{array}{l}\text { Western corella } \\
\text { White cockatoo } \\
\text { Salmon crested corella } \\
\text { Yellow crested cockatoo } \\
\text { Solomon corella } \\
\text { Philippine corella }\end{array}$ & $\begin{array}{l}\text { Cacatua pastinator } \\
\text { Cacatua alba } \\
\text { Cacatua moluccensis } \\
\text { Cacatua sulphurea } \\
\text { Cacatua ducorpsii } \\
\text { Cacatua haematuropygia }\end{array}$ \\
\hline Chimney swift & Chaetura pelagica & (Fitzwater 1988) & $\begin{array}{l}\text { Grey-rumped swift } \\
\text { Chapman's swift } \\
\text { Ashy-tailed swift } \\
\text { Short-tailed swift }\end{array}$ & $\begin{array}{l}\text { Chaetura cinereiventris } \\
\text { Chaetura chapmani } \\
\text { Chaetura andrei } \\
\text { Chaetura brachyura }\end{array}$ \\
\hline $\begin{array}{l}\text { Toresian crow } \\
\text { American crow } \\
\text { Chihuahuan raven }\end{array}$ & $\begin{array}{l}\text { Corvus orru } \\
\text { Corvus brachyrhynchos } \\
\text { Corvus cryptoleucus }\end{array}$ & (Fitzwater 1988) & $\begin{array}{l}\text { Collared crow } \\
\text { Fish crow } \\
\text { Jamaican crow } \\
\text { Mariana crow } \\
\text { Tamaulipus crow } \\
\text { Carrion crow } \\
\text { Large billed crow } \\
\text { Pied crow } \\
\text { Ethiopian raven } \\
\text { Thick-billed raven } \\
\text { Little raven }\end{array}$ & $\begin{array}{l}\text { Corvus pectoralis } \\
\text { Corvus ossifragus } \\
\text { Corvus jamaicensis } \\
\text { Corvus kubaryi } \\
\text { Corvus imparatus } \\
\text { Corvus corone } \\
\text { corvus macrorhynchos } \\
\text { Corvus albus } \\
\text { Corvus edithae } \\
\text { Corvus crassirostris } \\
\text { Corvus mellori }\end{array}$ \\
\hline $\begin{array}{l}\text { Australian magpie } \\
\text { Grey butcherbird }\end{array}$ & $\begin{array}{l}\text { Cracticus tibicen } \\
\text { Cracticus torquatus }\end{array}$ & $\begin{array}{l}\text { (Jones \& Thomas } \\
\text { 1999) } \\
\text { (Rock 2005) }\end{array}$ & $\begin{array}{l}\text { Black butcherbird } \\
\text { Black-backed butcherbird } \\
\text { Pied butcherbird } \\
\text { Hooded butcherbird }\end{array}$ & $\begin{array}{l}\text { Cracticus quoyi } \\
\text { Cracticus mentalis } \\
\text { Cracticus nigrogularis } \\
\text { Cracticus cassicus }\end{array}$ \\
\hline Little blue egret & Egretta caerulea & (Fitzwater 1988) & Slaty egret & Egretta vinaceigula \\
\hline
\end{tabular}




\begin{tabular}{|c|c|c|c|c|}
\hline Great egret & Egretta alba & & $\begin{array}{l}\text { Black egret } \\
\text { Tricoloured egret } \\
\text { Reddish egret } \\
\text { Snowy egret } \\
\text { Intermediate egret } \\
\text { Eastern reef egret } \\
\text { Little egret }\end{array}$ & $\begin{array}{l}\text { Egretta ardesiaca } \\
\text { Egretta tricolor } \\
\text { Egretta ruferscens } \\
\text { Egretta thula } \\
\text { Egretta intermedia } \\
\text { Egretta sacra } \\
\text { Egretta garzetta }\end{array}$ \\
\hline Brewers blackbird & Euphagus cyanocephalus & (Fitzwater 1988) & Rusty blackbird & Euphagus carolinus \\
\hline $\begin{array}{l}\text { American coot } \\
\text { Magpie lark }\end{array}$ & $\begin{array}{l}\text { Fulica americanus } \\
\text { Grallina cyanoleuca }\end{array}$ & (Fitzwater 1988) & $\begin{array}{l}\text { White-winged coot } \\
\text { Red-fronted coot } \\
\text { Giant coot } \\
\text { Red-knobbed coot } \\
\text { Torrent-lark }\end{array}$ & $\begin{array}{l}\text { Fulica leucoptera } \\
\text { Fulica rufifrous } \\
\text { Fulica gigantean } \\
\text { Fulica cristata } \\
\text { Grallina bruijni }\end{array}$ \\
\hline Welcome swallow & Hirundo neoxena & (Temby 2004) & $\begin{array}{l}\text { Pacific swallow } \\
\text { Barn swallow } \\
\text { White-throated swallow } \\
\text { Pearl-breasted swallow }\end{array}$ & $\begin{array}{l}\text { Hirundo tahitica } \\
\text { Hirundo rustica } \\
\text { Hirundo albigularis } \\
\text { Hirundo dimidiata }\end{array}$ \\
\hline Mississippi kite & Ictinia mississippiensis & $\begin{array}{l}\text { (Fitzwater 1988), } \\
\text { (Peterson \& } \\
\text { Brown 1985) }\end{array}$ & Plumbeous Kite & Ictinia plumbea \\
\hline $\begin{array}{l}\text { Ring-billed gull } \\
\text { Laughing gull } \\
\text { Herring gull } \\
\text { Silver gull } \\
\text { Lesser black-backed gull }\end{array}$ & $\begin{array}{l}\text { Larus delawarensis } \\
\text { Larus atricilla } \\
\text { Larus argentatus } \\
\text { Larus novaehollandiae } \\
\text { Larus fuscus }\end{array}$ & $\begin{array}{l}\text { (Belant 1997) } \\
\text { (Belant 1997) } \\
\text { (Belant 1997) } \\
\text { (Temby 2004) } \\
\text { (Rock 2005) }\end{array}$ & $\begin{array}{l}\text { Black-headed gull } \\
\text { Mew gull } \\
\text { Glaucous gull } \\
\text { California gull } \\
\text { Pacific gull } \\
\text { Great black-backed gull }\end{array}$ & $\begin{array}{l}\text { Larus ridibundus } \\
\text { Larus canus } \\
\text { Larus hyperboreus } \\
\text { Larus californicus } \\
\text { Larus pacificus } \\
\text { Larus marinus }\end{array}$ \\
\hline
\end{tabular}




\begin{tabular}{|c|c|c|c|c|}
\hline & & & $\begin{array}{l}\text { Grey gull } \\
\text { Western gull } \\
\text { Grey-headed gull } \\
\text { Black-billed gull } \\
\text { Mediterranean gull } \\
\text { Little gull } \\
\text { Slaty backed gull } \\
\text { Brown headed gull } \\
\text { White eyed gull }\end{array}$ & $\begin{array}{l}\text { Larus modestus } \\
\text { Larus occidentalis } \\
\text { Larus cirrocephalus } \\
\text { Larus bulleri } \\
\text { Larus melanocephalus } \\
\text { Larus minutes } \\
\text { Larus schistisagus } \\
\text { Larus brunnicephalus } \\
\text { Larus leucophthalmus }\end{array}$ \\
\hline Northern mockingbird & Mimus polyglottos & (Fitzwater 1988) & $\begin{array}{l}\text { Bahama mockingbird } \\
\text { Chalk-browed mockingbird } \\
\text { Long-tailed mockingbird } \\
\text { Tropical mockingbird }\end{array}$ & $\begin{array}{l}\text { Mimus gundlachii } \\
\text { Mimus saturninus } \\
\text { Mimus longicaudatus } \\
\text { Mimus gilvus }\end{array}$ \\
\hline Brown-headed cowbird & Molothrus ater & (Fitzwater 1988) & $\begin{array}{l}\text { Shiny cowbird } \\
\text { Giant cowbird } \\
\text { Screaming cowbird } \\
\text { Bronzed cowbird }\end{array}$ & $\begin{array}{l}\text { Molothrus bonariensis } \\
\text { Molothrus oryzivorus } \\
\text { Molothrus rufoaxillaris } \\
\text { Molothrus aeneus }\end{array}$ \\
\hline $\begin{array}{l}\text { Black-crowned night } \\
\text { heron }\end{array}$ & Nycticorax nycticorax & (Fitzwater 1988) & $\begin{array}{l}\text { Yellow-crowned night heron } \\
\text { Rufous night heron } \\
\text { White-backed night heron }\end{array}$ & $\begin{array}{l}\text { Nycticorax violaceus } \\
\text { Nycticorax caledonicus } \\
\text { Nycticorax leuconotus }\end{array}$ \\
\hline Double-crested cormorant & Phalacrocorax auritus & $\begin{array}{l}\text { (Taylor et al. } \\
\text { 2011) }\end{array}$ & $\begin{array}{l}\text { Great cormorant } \\
\text { Little pied cormorant } \\
\text { Common (European) shag } \\
\text { Rough-faced shag }\end{array}$ & $\begin{array}{l}\text { Phalacrocorax carbo } \\
\text { Phalacrocorax } \\
\text { melanoleucos } \\
\text { Phalacrocorax aristotelis } \\
\text { Phalacrocorax } \\
\text { carunculatus }\end{array}$ \\
\hline
\end{tabular}




\begin{tabular}{|c|c|c|c|c|}
\hline Common grackle & Quiscalus quiscalus & (Fitzwater 1988) & $\begin{array}{l}\text { Nicaraguan grackle } \\
\text { Carib grackle } \\
\text { Greater Antillean grackle } \\
\text { Great-tailed grackle }\end{array}$ & $\begin{array}{l}\text { Quiscalus nicaraguensis } \\
\text { Quiscalus lugubris } \\
\text { Quiscalus niger } \\
\text { Quiscalus mexicanus }\end{array}$ \\
\hline Australian white ibis & Threskiornis molucca & $\begin{array}{l}\text { (Martin et al. } \\
\text { 2010) }\end{array}$ & $\begin{array}{l}\text { Sacred ibis } \\
\text { Black-headed ibis } \\
\text { Straw-necked ibis }\end{array}$ & $\begin{array}{l}\text { Threskiornis aethiopicus } \\
\text { Threskiornis } \\
\text { melanocephalus } \\
\text { Threskiornis spinicollis }\end{array}$ \\
\hline American robin & Turdus migratorius & (Fitzwater 1988) & $\begin{array}{l}\text { Glossy black thrush } \\
\text { Kurrichane thrush } \\
\text { Brown-headed thrush } \\
\text { Redwing }\end{array}$ & $\begin{array}{l}\text { Turdus serranus } \\
\text { Turdus libonyanus } \\
\text { Turdus chrysolaus } \\
\text { Turdus iliacus } \\
\end{array}$ \\
\hline $\begin{array}{l}\text { Masked lapwing } \\
\text { (Spur-winged plover) }\end{array}$ & Vanellus miles & (Temby 2004) & $\begin{array}{l}\text { Northern lapwing } \\
\text { Banded lapwing } \\
\text { Spur-winged lapwing } \\
\text { Red-wattled lapwing }\end{array}$ & $\begin{array}{l}\text { Vanellus vanellus } \\
\text { Vanellus tricolor } \\
\text { Vanellus spinosis } \\
\text { Vanellus indicus }\end{array}$ \\
\hline
\end{tabular}





\section{References}

Adams, C. E., and K. J. Lindsey 2010. Urban Wildlife Management 2nd ed. CRC Press, Boca Ratan, FL.

Adams, L. W. 1994. Urban wildlife habitats: A landscape perspective. University of Minnesota Press, Minneapolis, MN.

Ajzen, I. 1991. The theory of planned behavior. Organizational Behavior and Human Decision Proesses 50:179-211.

Ajzen, I., and M. Fishbein 1980. Understanding attitudes and predicting social behaviour. Prentice-Hall, Englewood Cliffs, NJ.

Alberti, M. 2008. Advances in Urban Ecology. Springer, New York, NY.

Altmann, J. 1974. Observational study of behavior: sampling methods. Behaviour 69:227-267.

Arhonditsis, G., C. Stow, L. Steinberg, M. Kenney, R. Lathrop, S. McBride, and K. Reckhow. 2006. Exploring ecological patterns with structural equation modeling and Bayesian analysis. Ecological Modelling 192:385-409.

Bagchi, S., and C. Mishra. 2006. Living with large carnivores: predation on livestock by the snow leopard (Uncia uncia). Journal of Zoology 268:217-224.

Bale, C. L., J. B. Williams, and J. L. Charley. 1998. The impact of aspect on forest structure and floristics in some eastern Australian sites. Forest Ecology and Management 110:363-377.

Ballantyne, R., J. Packer, and J. Falk. 2011. Visitors' learning for environmental sustainability: Testing short- and long-term impacts of wildlife tourism experiences using structural equation modelling. Tourism Management 32:1243-1252.

Barnes, T. G., and B. U. Constantin. 1993. Managing urban pest bird problems in Kentucky. Kentucky Cooperative Extension Service report FOR 62. University of Kentucky, Lexington, KY.

Bath, A., and L. Farmer. 2000. Europe's carnivores - a survey of children's attitudes towards wolves, bears and otters. WWF UK Campaign for Europe's Carnivores. WWF-UK Report, Goldalming, Surrey, UK.

Bath, A., A. Olszanska, and H. Okarma. 2008. From a human dimensions perspective, the unknown large carnivore: public attitudes toward Eurasian lynx in Poland. Human Dimensions of Wildlife 13:31-46.

Bath, A. J., and T. Buchanan. 1989. Attitudes of interest groups in Wyoming toward wolf restoration in Yellowstone National Park. Wildlife Society Bulletin 17:519-525.

Beaven, B. M. 1996. Sap feeding behaviour of North Island kaka (Nestor meridionalis septentrionalis, Lorenz 1896) in plantation forests. MSc Thesis. Waikato University, Hamilton, New Zealand.

Beck, C. B. 2010. An introduction to plant structure and development: plant anatomy for the twenty-first century. Cambridge University Press, Cambridge, UK.

Beggs, J. R. 1988. Energetics of kaka in a South Island beech forest. MSc Thesis. University of Auckland, Auckland, NZ.

Beggs, J. R., and P. R. Wilson. 1987. Energetics of South Island kaka (Nestor meridionalis meridionalis) feeding on the larvae of kanuka longhorn beetles (Ochrocydus huttoni). New Zealand Journal of Ecology 10:143-147. 
Beggs, J. R., and P. R. Wilson. 1991. The kaka Nestor meridionalis, a New Zealand parrot endangered by introduced wasps and mammals. Biological Conservation 56:2338.

Belant, J. L. 1997. Gulls in urban environments: landscape-level management to reduce conflict. Landscape and Urban Planning 38:245-258.

Belant, J. L., S. K. Ickes, and T. W. Seamans. 1998. Importance of landfills to urbannesting herring and ring-billed gulls. Landscape and Urban Planning 43:11-19.

Berry, R. 1998. Reintroduction of kaka (Nestor meridionalis septentrionalis) to Mount Bruce Reserve, Wairarapa, New Zealand. Science for Conservation 89. Department of Conservation, Wellington, New Zealand.

Blair, R. B. 2001. Creating a homogeneous avifauna. Pages 459-486 in J. M. Marzluff, R. Bowman, and R. Donelly, editors. Avian Ecology and Conservation in an Urbanizing World. Kluwer Academic Publishers, Boston, MA.

Blendinger, P. G. 1999. Facilitation of sap-feeding birds by the white-fronted woodpecker in the Monte Desert, Argentina. The Condor 101:402-407.

Brejaart, R. 1994. Aspects of the ecology of kea, Nestor notabilis (Gould), at Arthur's Pass and Craigieburn Valley. MAS Thesis. Lincoln University, Christchurch, NZ.

Bright, A. D., M. J. Manfredo, and D. C. Fulton. 2000. Segmenting the public: an application of value orientations to wildlife planning in Colorado. Wildlife Society Bulletin 28:218-226.

Brockie, B. 1997. City nature : a guide to the plants and animals of New Zealand cities and towns. Viking, Auckland, NZ.

Brockie, R. E., and C. Duncan. 2012. Long term trends in Wellington City bird counts: 1969-2006. Notornis 59:1-6.

Buller, W. L. 1888. A history of the birds of New Zealand. The Author, London, UK.

Burdon, N. 2010. Magpie ends tour hopes. Southland Times, Invercargill. 30 Sept 2010, p. 20.

Burnham, K. P., and D. R. Anderson 2002. Model selection and multimodel inference: a practical information-theoretic approach. Springer, New York, NY.

Caithness, T. A. 1968. Poisoning gulls with alpha-chloralose near a New Zealand airfield. The Journal of Wildlife Management 32:279-286.

Carlos, A. W. D., A. D. Bright, T. L. Teel, and J. J. Vaske. 2009. Human-black bear conflict in urban areas: an integrated approach to management response. Human Dimensions of Wildlife 14:174-184.

Carpinter, B. 2010. Kaka start to flock back to the Bay. The Dominion Post, Wellington, NZ. 9 Oct 2010, p. 19.

Carter, J. K., and R. O. Blanchard. 1978. Electrical resistance related to phloem width in red maple. Canadian Journal of Forest Research-Revue Canadienne De Recherche Forestiere 8:90-93.

Chapman, A., M. G. Bradford, and C. J. Hoskin. 1999. Sap suckers: A novel bird 'guild' in wet sclerophyll forests of tropical north Queensland. Emu 99:69-72.

Charles, K. E. 2012. Tree damage in Wellington as a result of foraging for sap and barkdwelling invertebrates by the North Island kaka (Nestor meridionalis septentrionalis). Notornis 59:180-184.

Chawla, L. 1999. Life paths into effective environmental action. The Journal of Environmental Education 31.

Chilvers, B. L., C. J. Ryan, and G. J. Hickling. 1997. Factors affecting pilot-reported birdstrike rates at Christchurch International Airport, New Zealand. New Zealand Journal of Zoology 24:1-7. 
Chug, K. 2010. Kaka face new threat - from humans. The Dominion Post, Wellington, NZ. 12 Feb 2010, p. 1.

Clergeau, P., J. P. L. Savard, G. Mennechez, and G. Falardeau. 1998. Bird abundance and diversity along an urban-rural gradient: A comparative study between two cities on different continents. Condor 100:413-425.

Clout, M. 2001. Where protection is not enough: active conservation in New Zealand. Trends in Ecology \& Evolution 16:415-416.

Coimbra-Filho, A. F., and R. A. Mittermeier. 1976. Exudate-eating and tree-gouging in marmosets. Nature 262:630.

Coluccy, J. M., R. D. Drobney, D. A. Graber, S. L. Sheriff, and D. J. Witter. 2001. Attitudes of central Missouri residents toward local giant Canada geese and management alternatives. Wildlife Society Bulletin 29:116-123.

Conover, M. 2001. Resolving human-wildlife conflicts. The science of wildlife damage management. CRC Press, Boca Raton, FL.

Conover, M. R. 1997. Wildlife management by metropolitan residents in the United States: practices, perceptions, costs, and values. Wildlife Society Bulletin 25:306311.

Conover, M. R., and G. G. Chasko. 1985. Nuisance Canada goose problems in the eastern United States. Wildlife Society Bulletin 13:228-233.

Consorte-McCrea, A. G. 2011. Conservation of the maned wolf (Chrysocyon brachyurus): carnivore and people relationships in the southeast of Brazil. PhD Thesis. University of Kent, Cambridge, UK.

Crafts, A. S., and C. E. Crisp 1971. Phloem transport in plants. W. H. Freeman, San Francisco, CA.

Craig, J. 1979. Habitat variation in the social organization of a communal gallinule, the pukeko, Porphyrio porphyrio melanotus. Behavioral Ecology and Sociobiology 5:331-358.

Craig, J., S. Anderson, M. Clout, B. Creese, N. Mitchell, J. Ogden, M. Roberts, and G. Ussher. 2000. Conservation issues in New Zealand. Annual Review of Ecology and Systematics 31:61-78.

Craig, S. A. 1985. Social organization, reproduction and feeding behaviour of a population of yellow-bellied gliders, Petaurus australis (Marsupialia: Petauridae) Australian Wildlife Research 12:1-18.

Decker, D. J., and L. C. Chase. 1997. Human dimensions of living with wildlife: a management challenge for the 21st century. Wildlife Society Bulletin 25:788795.

Decker, D. J., and K. G. Purdy. 1988. Toward a concept of wildlife acceptance capacity in wildlife management. Wildlife Society Bulletin 16:53-57.

del Hoyo, J., A. Elliott, and J. Sargatal, editors. 1992. Handbook of the Birds of the World, Vol 1-14. Lynx [for] ICBP, Barcelona, Spain.

Department of Conservation. 2012. Annual Report for the year ended 30 June 2012. Department of Conservation, Wellington, NZ.

Diamond, J., and A. B. Bond 1999. Kea, Bird of Paradox. University of California Press, Berkeley, $\mathrm{CA}$.

Diamond, J., and A. B. Bond. 2004. Social play in kaka (Nestor meridionalis) with comparisons to kea (Nestor notabilis). Behaviour 141:777-798.

Dickman, A. J. 2010. Complexities of conflict: the importance of considering social factors for effectively resolving human-wildlife conflict. Animal Conservation 13:458-466. 
Dilks, P. 2004. Population status, breeding and ecology of Chatham Island tui (Prosthemadera novaeseelandiae chathamensis). Notornis 51:217-226.

Distefano, E. 2004. Human-wildlife conflict worldwide: collection of case studies, analysis of management strategies and good practices. Food and Agriculture Organisation of the United Nations, Rome, Italy. Available online, from www.fao.org/SARD/COMMON/ecg/1357/en/HWC final.pdf.

Ditchkoff, S. S., S. T. Saalfeld, and C. J. Gibson. 2006. Animal behavior in urban ecosystems: Modifications due to human-induced stress. Urban Ecosystems 9:512.

Dixon, J., and A. Dupuis. 2003. Urban intensification in Auckland, New Zealand: A challenge for new urbanism. Housing Studies 18:353-368.

Dopson, S., P. J. de Lange, C. C. Ogle, B. D. Rance, S. P. Courtney, and J. Molloy. 1999. The conservation requirements of New Zealand's nationally threatened vascular plants. Threatened species occasional publication. Department of Conservation, Wellington, NZ.

Douglas, A. E. 2006. Phloem-sap feeding by animals: problems and solutions. Journal of Experimental Botany 57:747-754.

Dowle, M., and E. Deane. 2009. Attitudes to native bandicoots in an urban environment. European Journal of Wildlife Research 55:45-52.

Dunlap, R. E., and R. B. Heffernan. 1975. Outdoor recreation and environmental concern: an empirical examination. Rural sociology 40:18-30.

Dunn, R. R., M. C. Gavin, M. C. Sanchez, and J. N. Solomon. 2006. The pigeon paradox: dependence of global conservation on urban nature. Conservation Biology 20:1814-1816.

Eberhardt, L. S. 2000. Use and selection of sap trees by yellow-bellied sapsuckers. The Auk 117:41-51.

Evans, K. L., D. E. Chamberlain, B. J. Hatchwell, R. D. Gregory, and K. J. Gaston. 2011. What makes an urban bird? Global Change Biology 17:32-44.

Eyre, T. J., and R. L. Goldingay. 2005. Characteristics of sap trees used by yellow-bellied gliders in southern Queensland. Wildlife Research 32:23-35.

Fall, M. W., and W. B. Jackson. 2002. The tools and techniques of wildlife damage management - changing needs: an introduction. International Biodeterioration \& Biodegradation 49:87-91.

Fazio, R., J.-M. Chen, E. McDonel, and S. Sherman. 1982. Attitude accessibility, attitudebehavior consistency, and the strength of the object-evaluation association. Journal of Experimental Social Psychology 18:339-357.

Fazio, R. H., and M. P. Zanna. 1981. Direct experience and attitude-behavior consistency. Pages 161-202 in L. Berkowitz, editor. Advances in Experimental Social Psychology Volume 14. Academic Press Inc., New York, NY.

Fitzwater, W. D. 1988. Solutions to urban bird problems. Pages 254-259 in A. C. Crabb, and R. E. Marsh, editors. 13th Vertebrate Pest Conference, University of Nebraska, Lincoln, NE.

Francis, R. A., and M. A. Chadwick. 2012. What makes a species synurbic? Applied Geography 32:514-521.

Fuller, R. A., P. H. Warren, P. R. Armsworth, O. Barbosa, and K. J. Gaston. 2008. Garden bird feeding predicts the structure of urban avian assemblages. Diversity and Distributions 14:131-137.

Gadd, M. E. 2005. Conservation outside of parks: Attitudes of local people in Laikipia, Kenya. Environmental Conservation 32:50-63. 
Garrod, A. H. 1872. Note on the tongue of the Psittacine genus Nestor. Proceedings of the Zoological Society:787-789.

Glikman, J., J. Vaske, A. Bath, P. Ciucci, and L. Boitani. 2012. Residents' support for wolf and bear conservation: the moderating influence of knowledge. European Journal of Wildlife Research 58:295-302.

Goldingay, R. L. 1987. Sap feeding by the marsupial Petaurus australis: an enigmatic behaviour? Oecologia 73:154-158.

Goldingay, R. L. 1991. An evaluation of hypotheses to explain the pattern of sap feeding by the yellow-bellied glider, Petaurus australis. Australian Journal of Ecology 16:491-500.

Green, R. J., and K. Higginbottom. 2000. The effects of non-consumptive wildlife tourism on free-ranging wildlife: A review. Pacific Conservation Biology 6:183-197.

Greene, T. C., R. G. Powlesland, P. J. Dilks, and L. Moran. 2004. Research summary and options for conservation of kaka (Nestor meridionalis). DOC science internal series. Department of Conservation, Wellington, NZ.

Grueber, C. E., S. Nakagawa, R. J. Laws, and I. G. Jamieson. 2011. Multimodel inference in ecology and evolution: challenges and solutions. Journal of Evolutionary Biology 24:699-711.

Harding, E. G., S. L. Vehrencamp, and P. D. Curtis. 2009. External characteristics of houses prone to woodpecker damage. Human-Wildlife Conflicts 3:136-144.

Healy, C. 2012. Kaka rescued from busy city street. East \& Bays Courier, Auckland, NZ. 2 Nov 2012, p.

Heberlein, T., G. Ericsson, ouml, and ran. 2005. Ties to the countryside: accounting for urbanites attitudes toward hunting, wolves, and wildlife. Human Dimensions of Wildlife 10:213-227.

Heinrich, B. 1992. Maple sugaring by red squirrels. Journal of Mammalogy 73:51-54.

Higgins, P. J., editor. 1999. Handbook of Australian, New Zealand and Antarctic birds. Vol 4: Parrots to Dollarbird. Oxford University Press, Melbourne, Australia.

Hill, M. 2003. Wellington Botanic Garden. RECN512 practicum heritage inventory (research report), towards a degree in Museum and Heritage Studies. Victoria University of Wellington, Wellington, NZ.

Hill, N. J., K. A. Carbery, and E. M. Deane. 2007. Human-possum conflict in urban Sydney, Australia: public perceptions and implications for species management. Human Dimensions of Wildlife 12:101-113.

Hines, J. M., H. R. Hungerford, and A. N. Tomera. 1987. Analysis and synthesis of research on responsible environmental behavior: a meta-analysis. The Journal of Environmental Education 18:1-8.

Holbrook, N. M., and M. A. Zwieniecki 2005. Vascular transport in plants. Elsevier Academic Press, Amsterdam, Netherlands.

Holloway, J. T. 1948. Damage by kaka in rimu forests of western Southland. New Zealand Journal of Forestry 5:437-438.

Homer, P. M., and L. R. Kahle. 1988. A structural equation test of the value-attitudebehavior hierarchy. Journal of Personality and Social Psychology 54:638-646.

Howard, P., and D. N. Jones 2004. A qualitative study of wildlife feeding in south-east Queensland. Royal Zoological Society of New South Wales, Sydney, Australia.

Innes, J. 1980. Kaka damage to exotics in Tawhai and Granville forests. Unpubl. N.Z. Forest Service Report. FRI, Rotorua, NZ.

Innes, J. 1994. Kaka damage to exotic plantation trees at Whirinaki Forest - a preliminary report. Landcare Research Contract Report: LC9495/36. Manaaki Whenua Landcare Research, Hamilton, NZ. 
Ishigame, G., and G. S. Baxter. 2007. Practice and attitudes of suburban and rural dwellers to feeding wild birds in southeast Queensland, Australia. Ornithological Science 6:11-19.

IUCN 2012. The IUCN Red List of threatened species: Nestor meridionalis. Accessed on 26 June 2012, from www.iucnredlist.org/apps/redlist/details/106001412/0.

Johnson, J. B., and K. S. Omland. 2004. Model selection in ecology and evolution. Trends in Ecology \& Evolution 19:101-108.

Jones, D. 2011. An appetite for connection: why we need to understand the effect and value of feeding wild birds. Emu 111:I-VII.

Jones, D. N., and S. J. Reynolds. 2008. Feeding birds in our towns and cities: a global research opportunity. Journal of Avian Biology 39:265-271.

Jones, D. N., and L. K. Thomas. 1998. Managing to live with Brisbane's wildlife: magpies and the management of positive and negative interactions. Proceedings of the Royal Society of Queensland 107:45-49.

Jones, D. N., and L. K. Thomas. 1999. Attacks on humans by Australian magpies: management of an extreme suburban human-wildlife conflict. Wildlife Society Bulletin 27:473-478.

Jonker, S. A., R. M. Muth, J. F. Organ, R. R. Zwick, and W. F. Siemer. 2006. Experiences with beaver damage and attitudes of Massachusetts residents toward beaver. Wildlife Society Bulletin 34:1009-1021.

Kaczensky, P., M. Blazic, and H. Gossow. 2004. Public attitudes towards brown bears (Ursus arctos) in Slovenia. Biological Conservation 118:661-674.

Kals, E., D. Schumacher, and L. Montada. 1999. Emotional affinity toward nature as a motivational basis to protect nature. Environment and Behavior 31:178-202.

Kark, S., A. Iwaniuk, A. Schalimtzek, and E. Banker. 2007. Living in the city: can anyone become an 'urban exploiter'? Journal of Biogeography 34:638-651.

Karori Sanctuary Trust. 2011. Annual Report. Karori Sanctuary Trust, Wellington, NZ.

Karori Sanctuary Trust. 2012a. Annual Report. Karori Sanctuary Trust, Wellington, NZ.

Karori Sanctuary Trust 2012b. Report a bird (sighting). Karori Sanctuary Trust, Wellington, NZ. Accessed on 12 November 2012, from www.visitzealandia.com/contact-us/report-a-bird/.

Kavanagh, R. P. 1987. Forest phenology and its effect on foraging behaviour and selection of habitat by the Yellow-Bellied Glider, Petaurus australis Shaw. Australian Wildlife Research 14:371 - 384.

Kea Conservation Trust 2013a. Human - Kea Conflict. Kea Conservation Trust, NZ. Accessed on 31 January 2013, from www.keaconservation.co.nz/keaendangeredspecies/keawildpopulation/humank eaconflict.

Kea Conservation Trust 2013b. Kea Projects. Kea Conservation Trust, NZ. Accessed on 31 January 2013, from www.keaconservation.co.nz/keaprojects.

Kellert, S. R. 1983. Affective, cognitive, and evaluative perceptions of animals. Human Behavior \& Environment: Advances in Theory \& Research 6:241-267.

Kellert, S. R., M. Black, C. R. Rush, and A. J. Bath. 1996. Human culture and large carnivore conservation in North America. Conservation Biology 10:977-990.

Kelly, D., and J. J. Sullivan. 2010. Life histories, dispersal, invasions, and global change: progress and prospects in New Zealand ecology, 1989-2029. New Zealand Journal of Ecology 34:207-217.

Kenward, R. E. 1982. Bark stripping by grey squirrels - some recent research. Quarterly Journal of Forestry 76:108-121. 
Kenward, R. E., T. Parish, J. Holm, and E. H. M. Harris. 1988. Grey squirrel bark-stripping. I. The roles of tree quality, squirrel learning and food abundance. Quarterly Journal of Forestry 52:9-20.

Kile, G. A., J. D. Kellas, and R. G. Jarrett. 1982. Factors influencing electrical resistance in stems of Eucalyptus obliqua, Eucalyptus globulus subsp bicostata and Eucalyptus viminalis. Australian Forest Research 12:129-138.

Kingsford, R. T., J. E. M. Watson, C. J. Lundquist, O. Venter, L. Hughes, E. L. Johnston, J. Atherton, M. Gawel, D. A. Keith, B. G. Mackey, C. Morley, H. P. Possingham, B. Raynor, H. F. Recher, and K. A. Wilson. 2009. Major conservation policy issues for biodiversity in Oceania. Conservation Biology 23:834-840.

Kline, R. B. 2005. Principles and practice of structural equation modeling. Guilford Press, New York.

Knight, J. 2000. Natural enemies: people-wildlife conflicts in anthropological perspective. Routledge, New York, NY.

König, A. 2008. Fears, attitudes and opinions of suburban residents with regards to their urban foxes. European Journal of Wildlife Research 54:101-109.

Kozma, J. M. 2010. Characteristics of trees used by white-headed woodpeckers for sap feeding in Washington. Northwestern Naturalist 91:81-86.

Kretser, H. E., P. D. Curtis, J. D. Francis, R. J. Pendall, and B. A. Knuth. 2009. Factors affecting perceptions of human-wildlife interactions in residential areas of northern New York and implications for conservation. Human Dimensions of Wildlife 14:102-118.

Krimowa, S. 2011. Pigeons and People: resource ecology and human dimensions of urban wildlife. MSc Thesis. Victoria University, Wellington, NZ.

$\mathrm{Ku}, \mathrm{C}$., J. Jang, and S. Mun. 2007. Exploitation of polyphenol-rich pine barks for potent antioxidant activity. Journal of Wood Science 53:524-528.

Lacher, T. E., Jr., G. A. B. d. Fonseca, C. Alves, Jr., and B. Magalhaes-Castro. 1984. Parasitism of trees by marmosets in a central Brazilian gallery forest. Biotropica 16:202-209.

Lawson, D., C. Lamar, and M. Schwartz. 2008. Quantifying plant population persistence in human-dominated landscapes. Conservation Biology 22:922-928.

Lehner, P. N. 1996. Handbook of ethological methods. Cambridge University Press, Cambridge, UK.

Lepczyk, C. A., A. G. Mertig, and J. G. Liu. 2004. Assessing landowner activities related to birds across rural-to-urban landscapes. Environmental Management 33:110-125.

Lischka, S. A., S. J. Riley, and B. A. Rudolph. 2008. Effects of impact perception on acceptance capacity for white-tailed deer. Journal of Wildlife Management 72:502-509.

Liu, F., W. J. McShea, D. L. Garshelis, X. Zhu, D. Wang, and L. Shao. 2011. Human-wildlife conflicts influence attitudes but not necessarily behaviors: Factors driving the poaching of bears in China. Biological Conservation 144:538-547.

Long, A. M. 2011. Orientation of sap wells excavated by yellow-bellied sapsuckers. The Wilson Journal of Ornithology 123:164-167.

Luniak, M. 2004. Synurbization - adaptation of animal wildlife to urban development. Pages 50-55 in W. W. Shaw, L. K. Harris, and L. Vandruff, editors. Proceedings of the 4th International Symposium on Urban Wildlife Conservation, University of Arizona, Tucson, AZ.

Macdonald, D. W., and K. Service 2007. Key Topics in Conservation Biology. Blackwell Publishing, Malden, MA. 
Maciusik, B., M. Lenda, and P. Skorka. 2010. Corridors, local food resources, and climatic conditions affect the utilization of the urban environment by the black-headed gull Larus ridibundus in winter. Ecological Research 25:263-272.

Mackowski, C. M. 1988. Characteristics of eucalypts incised for sap by the yellow-bellied glider Petaurus australis Shaw (Marsupialia: Petauridae), in northeastern New South Wales. Australian Mammalogy 11:5-14.

Madden, F. 2004. Creating coexistence between humans and wildlife: global perspectives on local efforts to address human-wildlife conflict. Human Dimensions of Wildlife 9:247-257.

Manfredo, M. J. 2008. Who Cares about Wildlife? Social Science Concepts for Exploring Human-Wildlife Relationships and Conservation Issues. Springer, New York, NY.

Manfredo, M. J., and A. A. Dayer. 2004. Concepts for exploring the social aspects of human-wildlife conflict in a global context. Human Dimensions of Wildlife 9:120.

Marshall, K., R. White, and A. Fischer. 2007. Conflicts between humans over wildlife management: on the diversity of stakeholder attitudes and implications for conflict management. Biodiversity and Conservation 16:3129-3146.

Martin, J., K. French, and R. Major. 2010. Population and breeding trends of an urban coloniser: the Australian white ibis. Wildlife Research 37:230-239.

Martin, P. R., F. Bonier, and I. T. Moore. 2009. First observation of sap well use and maintenance by the glossy flowerpiercer (Diglossa lafresnayii) (Thraupidae). Wilson Journal of Ornithology 121:213-215.

Martinez-Trinidad, T., W. T. Watson, M. A. Arnold, L. Lombardini, and D. N. Appel. 2010. Comparing various techniques to measure tree vitality of live oaks. Urban Forestry \& Urban Greening 9:199-203.

Marzluff, J. M. 2001. Worldwide urbanization and its effects on birds. Pages 19-38 in J. M. Marzluff, R. Bowman, and R. Donelly, editors. Avian ecology and conservation in an urbanizing world. Kluwer Academic Publishers, Norwell, MA.

Massei, G., R. J. Quy, J. Gurney, and D. P. Cowan. 2010. Can translocations be used to mitigate human-wildlife conflicts? Wildlife Research 37:428-439.

McCleery, R. A., R. B. Ditton, J. Sell, and R. R. Lopez. 2006. Understanding and improving attitudinal research in wildlife sciences. Wildlife Society Bulletin 34:537-541.

McKinney, M. L. 2006. Urbanization as a major cause of biotic homogenization. Biological Conservation 127:247-260.

Medway, D. G. 2005. Feeding association of tui (Prosthemadera novaeseelandiae) with North Island kaka (Nestor meridionalis septentrionalis). Notornis 52:111-112.

Messmer, T. A. 2000. The emergence of human-wildlife conflict management: turning challenges into opportunities. International Biodeterioration \& Biodegradation 45:97-102.

Messmer, T. A. 2009. Human-wildlife conflicts: emerging challenges and opportunities. Human-Wildlife Conflicts 3:10-17.

Miller, J. R. 2005. Biodiversity conservation and the extinction of experience. Trends in Ecology \& Evolution 20:430-434.

Miller, J. R., and R. J. Hobbs. 2002. Conservation where people live and work. Conservation Biology 16:330-337.

Miskelly, C., R. Empson, and K. Wright. 2005. Forest birds recolonising Wellington. Notornis 52:21-26.

Miskelly, C. M., D. J. E., G. P. Elliott, R. A. Hitchmough, R. G. Powlesland, H. A. Robertson, P. M. Sagar, R. P. Scofield, and G. A. Taylor. 2008. Conservation status of New Zealand birds, 2008. Notornis 55:117-135. 
Moller, A. P. 2009. Successful city dwellers: a comparative study of the ecological characteristics of urban birds in the Western Palearctic. Oecologia 159:849-858.

Moorhouse, R., T. Greene, P. Dilks, R. Powlesland, L. Moran, G. Taylor, A. Jones, J. Knegtmans, D. Wills, M. Pryde, I. Fraser, A. August, and C. August. 2003. Control of introduced mammalian predators improves kaka Nestor meridionalis breeding success: reversing the decline of a threatened New Zealand parrot. Biological Conservation 110:33-44.

Moorhouse, R. J. 1991. Annual variation in productivity of North Island kaka on Kapiti Island, New Zealand. Acta XX Congressus Internationalis Ornithologici:690-696.

Moorhouse, R. J. 1997. The diet of the North Island kaka (Nestor meridionalis septentrionalis) on Kapiti Island. New Zealand Journal of Ecology 21:141-152.

Moorhouse, R. J., M. J. Sibley, B. D. Lloyd, and T. C. Greene. 1999. Sexual dimorphism in the North Island kaka Nestor meridionalis septentrionalis: selection for enhanced male provisioning ability? Ibis 141:644-651.

Morton, J. 2011. Innovative wetland to make Rotorua's name. New Zealand Herald, Auckland, NZ. 01 Oct 2011, p. A015.

Moskell, C., S. Broussard Allred, and G. Ferenz. 2010. Examining motivations and recruitment strategies for urban forestry volunteers. Cities and the Environment (Online) 3: Article 9.

Mussen, D. 2012. Spray-on repellent could outwit incorrigible kea. The Press, Christchurch, NZ. 21 Sept 2012, p. 3.

Naughton-Treves, L., R. Grossberg, and A. Treves. 2003. Paying for tolerance: rural citizens' attitudes toward wolf depredation and compensation. Conservation Biology 17:1500-1511.

Naughton-Treves, L., and A. Treves. 2005. Socio-ecological factors shaping local support for wildlife: crop-raiding by elephants and other wildlife in Africa. Pages 252-277 in R. Woodroffe, S. Thirgood, and A. Rabinowitz, editors. People and Wildlife: Conflict or Co-existence? Cambridge University Press, Cambridge, UK.

Neems, J. 2009. Birds shining examples of conservation success. Waikato Times, Hamilton, NZ. 3 Oct 2009, p. 11.

New Zealand Notable Trees Trust 2012. Notable Trees of New Zealand, Nelson, NZ. Accessed on 12 December 2012, from www.notabletrees.org.nz.

NIWA 2012. Climate Summaries. Accessed on 31 January 2013, from www.niwa.co.nz/education-and-training/schools/resources/climate/summary.

Nyhus, P. J., and R. T. Sumianto. 2000. Crop-raiding elephants and conservation implications at Way Kambas National Park, Sumatra, Indonesia. Oryx 34:262274.

O'Donnell, C. F. G. 1993. More sap feeding by the kaka. Notornis 40:79-80.

O'Donnell, C. F. J., and P. J. Dilks. 1989. Sap-feeding by the kaka (Nestor meridionalis) in South Westland New Zealand. Notornis 36:65-71.

O'Donnell, C. F. J., and P. J. Dilks. 1994. Foods and foraging of forest birds in temperate rainforest, South Westland, New Zealand. New Zealand Journal of Ecology 18:87-107.

O'Donnell, C. F. J., and G. Rasch. 1991. Conservation of Kaka in New Zealand: A review of status, threats, priorities for research and implications for management. Science and Research Internal Report No. 101. Department of Conservation, Wellington, NZ.

O'Sullivan, P. 2011. Peckish pukeko harm crops. Hawkes Bay Today, Hastings, NZ. 1 Dec 2011, p. A017. 
O'Donnell, C. F. J., and G. Rasch. 1991. Conservation of kaka in New Zealand: A review of status, threats, priorities for research and implications for management. Science and Research internal report no. 101. Department of Conservation, Wellington.

Ostry, M. E., and T. H. Nicholls. 1976. How to identify sapsucker injury on trees. USDA Forest Service leaflet. North Central Forest Experiment Station, St. Paul, MN.

Parker, J. 2009. An analysis of urban ecological knowledge and behaviour in Wellington, New Zealand. MSc Thesis. Victoria University of Wellington, Wellington, NZ.

Pate, J., E. Shedley, D. Arthur, and M. Adams. 1998. Spatial and temporal variations in phloem sap composition of plantation-grown Eucalyptus globulus. Oecologia 117:312-322.

Patterson, M. E., J. M. Montag, and D. R. Williams. 2003. The urbanization of wildlife management: Social science, conflict, and decision making. Urban Forestry \& Urban Greening 1:171-183.

Peat, N. 1995. Kea advocacy strategy: Towards resolving conflicts between kea and people. Department of Conservation, Dunedin, NZ.

Pejchar, L., and J. Jeffrey. 2004. Sap-feeding behavior and tree selection in the endangered Akiapolaau (Hemignathus munroi) in Hawaii. The Auk 121:548-556.

Pennington, D. N., J. Hansel, and R. B. Blair. 2008. The conservation value of urban riparian areas for landbirds during spring migration: Land cover, scale, and vegetation effects. Biological Conservation 141:1235-1248.

Peterson, B. R., and C. S. Brown. 1985. Aggressive behavior of Mississppi kites in suburban areas. Proceedings of the Great Plains Wildlife Damage Control Workshop, University of Nebraska, Lincoln, NE.

Peterson, M. N., J. L. Birckhead, K. Leong, M. J. Peterson, and T. R. Peterson. 2010. Rearticulating the myth of human-wildlife conflict. Conservation Letters 3:7482.

Plamping, K., M. Haigh, M. J. Cullis, and R. E. Jenkins. 2008. Evaluation of cambial electrical resistance for the appraisal of tree vitality on reclaimed coal lands. International Journal of Mining, Reclamation and Environment 23:21-32.

Powlesland, R. G., T. C. Greene, P. J. Dilks, R. J. Moorhouse, L. R. Moran, G. Taylor, A. Jones, D. E. Wills, C. K. August, and C. L. August. 2009. Breeding biology of the New Zealand kaka (Nestor meridionalis) (Psittacidae, Nestorinae). 56 56:11-33.

Pruett-Jones, S., J. R. Newman, C. Newman, M., M. L. Avery, and J. R. Lindsay. 2007. Population viability analysis of monk parakeets in the United States and examination of alternative management strategies. Human-Wildlife Conflicts 1:35-44.

Rauwald, K. S., and C. F. Moore. 2002. Environmental attitudes as predictors of policy support across three countries. Environment and Behavior 34:709-739.

Riley, S. J., and D. J. Decker. 2000. Wildlife stakeholder acceptance capacity for cougars in Montana. Wildlife Society Bulletin 28:931-939.

Rilkoff, M. 2012. New wetlands to keep park lakes cleaner. Taranaki Daily News, New Plymouth, NZ. 6 Aug 2012, p. 4.

Rittel, H. J., and M. Webber. 1973. Dilemmas in a general theory of planning. Policy Sciences 4:155-169.

Robertson, C. J. R., P. Hyvonen, M. J. Fraser, and C. R. Pickard 2007. Atlas of bird distribution in New Zealand 1999-2004. Ornithological Society of New Zealand, Wellington, NZ.

Rock, P. 2005. Urban gulls: problems and solutions. British Birds 98:338-355.

Rollinson, D. J., R. O'Leary, and D. N. Jones. 2003. The practice of wildlife feeding in suburban Brisbane. Corella 27:52-58. 
Ryan, A. C. 2011. The distribution, density, and movements of feral pigeons Columba livia and their relationship with people. MSc Thesis. Victoria University of Wellington, Wellington, NZ.

Sacchi, R., A. Gentilli, E. Razzetti, and F. Barbieri. 2002. Effects of building features on density and flock distribution of feral pigeons Columba livia var. domestica in an urban environment. Canadian Journal of Zoology-Revue Canadienne De Zoologie 80:48-54.

Schafer, J. L., and J. W. Graham. 2002. Missing data: our view of the state of the art. Psychological Methods 7:147-177.

Schlatter, R. P., and P. Vergara. 2005. Magellanic woodpecker (Campephilus magellanicus) sap feeding and its role in the Tierra del Fuego forest bird assemblage. Journal of Ornithology 146:188-190.

Scott, I. 2012. Some impacts of wildlife in a South Island high country farming venture. Kokako 19:15-18.

Sha, J. C. M., M. D. Gumert, B. Lee, A. Fuentes, S. Rajathurai, S. Chan, and L. Jones-Engel. 2009. Status of the long-tailed macaque Macaca fascicularis in Singapore and implications for management. Biodiversity and Conservation 18:2909-2926.

Shepherd, W., and W. Cook 1988. Botanic Garden Wellington : a New Zealand history 1840-1987. Millwood Press, Wellington, NZ.

Sillero-Zubiri, C., M. Hoffmann, and D. W. Macdonald. 2004. Canids: foxes, wolves, jackals and dogs. Status survey and conservation action plan. IUCN/SSC Canid Specialist Group, Gland, Switzerland and Cambridge, UK.

Skelly, S. M., and J. M. Zajicek. 1998. The effect of an interdisciplinary garden program on the environmental attitudes of elementary school students. HortTechnology 8:579-583.

Smith, A. P. 1982. Diet and feeding strategies of the marsupial sugar glider in temperate Australia. Journal of Animal Ecology 51:149-166.

Snyder, M. A. 1992. Selective herbivory by Albert's squirrel mediated by chemical variability in Ponderosa Pine. Ecology 73:1730-1741.

Statistics New Zealand 2006a. Census of Population and Dwellings: Table Builder, Wellington, NZ. Accessed on 25 Aug 2012, from http://www.stats.govt.nz/tools and services/tools/TableBuilder.aspx.

Statistics New Zealand. 2006b. New Zealand in profile. Statistics New Zealand, Wellington, NZ.

Stewart, C. M., J. F. Melvin, Ditchbur.N, S. H. Tham, and E. Zerdoner. 1973. Effect of season of growth on chemical composition of cambial saps of Eucalyptus regnans trees. Oecologia 12:349-372.

Tarrant, M. A., A. D. Bright, and H. Ken Cordell. 1997. Attitudes toward wildlife species protection: assessing moderating and mediating effects in the value - attitude relationship. Human Dimensions of Wildlife 2:1-20.

Tate, J., Jr. 1973. Methods and annual sequence of foraging by the sapsucker. The Auk 90:840-856.

Taylor, B., D. Andrews, and G. S. Fraser. 2011. Double-crested cormorants and urban wilderness: conflicts and management. Urban Ecosystems 14:377-394.

Temby, I. D. 2004. Urban wildlife issues in Australia. Pages 26-34 in W. W. Shaw, L. K. Harris, and L. Vandruff, editors. Proceedings of the 4th International Symposium on Urban Wildlife Conservation, University of Arizona, Tucson, AZ.

Temby, I. D. 2010. Managing Impacts of the Little Corella on the Fleurieu Peninsula. Management report. Autumn 2010. Accessed from 
http://www.alexandrina.com.au/webdata/resources/files/Managing Impacts o f Little Corellas - Ian Temby report.pdf.

Thornton, C., and M. S. Quinn. 2009. Coexisting with cougars: public perceptions, attitudes, and awareness of cougars on the urban-rural fringe of Calgary, Alberta, Canada. Human-Wildlife Conflicts 3:282-295.

Treves, A., R. B. Wallace, L. Naughton-Treves, and A. Morales. 2006. Co-managing human-wildlife conflicts: a review. Human Dimensions of Wildlife 11:383-396.

van Horik, J., B. Bell, and K. C. Burns. 2007. Vocal ethology of the North Island kaka (Nestor meridionalis septentrionalis). New Zealand Journal of Zoology 34:337345.

van Horik, J. O. 2005. Vocal communication, behaviour and ecology of the North Island kaka (Nestor meridionalis septentrionalis) on Kapiti Island, New Zealand. MSc Thesis. Victoria University of Wellington, Wellington, NZ.

Waikato Regional Council. 2012. Report on the Hamilton Halo project - Five year review. Waikato Regional Council, Hamilton, NZ.

Walker, S., R. Price, D. Rutledge, R. T. T. Stephens, and W. G. Lee. 2006. Recent loss of indigenous cover in New Zealand New Zealand Journal of Ecology 30:169-177.

Wannan, O. 2012. Freed pair of kaka raise chicks in town belt. The Dominion Post, Wellington, NZ. 20 Dec 2012, p. A10.

Weathers, W. W., W. A. Buttemer, A. M. Hayworth, and K. A. Nagy. 1984. An evaluation of time-budget estimates of daily energy expenditure in birds. The Auk 101:459472.

Weiser, E. L., and A. N. Powell. 2010. Does garbage in the diet improve reproductive output of glaucous gulls? Condor 112:530-538.

Wellington City Council. 1998. Capital Spaces. Open space strategy for Wellington. Wellington City Council, Wellington, NZ.

Wellington City Council. 2007. Biodiversity Action Plan. Wellington City Council, Wellington, NZ.

Wellington City Council 2012a. About Wellington: Facts and Figures. Accessed on 31 January 2013, from http://www.wellington.govt.nz/aboutwgtn/glance/index.html.

Wellington City Council. 2012b. Draft Town Belt Management Plan. Wellington City Council, Wellington, NZ.

Wellington City Council 2012c. Wellington 2040: Wellington Today. Accessed on 31 January 2013, from http://www.wellington2040.co.nz/unfoldingfuture/wellington-today.

Wellington City Council 2013. Wellington City Council Community Profile. Accessed on 31 January 2013, from http://profile.idnz.co.nz/Default.aspx?id=366\&pg=8000\&gid=10.

Wells, N. M., and K. S. Lekies. 2006. Nature and the life course: Pathways from childhood nature experiences to adult environmentalism. Children, Youth and Environments 16:1-24.

West, B. C., and J. A. Parkhurst. 2002. Interactions between deer damage, deer density, and stakeholder attitudes in Virginia. Wildlife Society Bulletin 30:139-147.

West, R. 2005. Council ducks for cover on pigeons. The Daily News. 13 July 2005, p. 3.

White, P. C. L., N. V. Jennings, A. R. Renwick, and N. H. L. Barker. 2005. Review: Questionnaires in ecology: a review of past use and recommendations for best practice. Journal of Applied Ecology 42:421-430.

White, P. C. L., and A. L. Ward. 2010. Interdisciplinary approaches for the management of existing and emerging human-wildlife conflicts. Wildlife Research 37:623-629. 
White, R. M., A. Fischer, K. Marshall, J. M. J. Travis, T. J. Webb, S. di Falco, S. M. Redpath, and R. van der Wal. 2009. Developing an integrated conceptual framework to understand biodiversity conflicts. Land Use Policy 26:242-253.

Whiting, A. E., and K. K. Miller. 2008. Examining the Living with Possums policy in Victoria, Australia: community knowledge, support and compliance. Pacific Conservation Biology 14:169-176.

Whittingham, M. J., P. A. Stephens, R. B. Bradbury, and R. P. Freckleton. 2006. Why do we still use stepwise modelling in ecology and behaviour? Journal of Animal Ecology 75:1182-1189.

Wilson, P. R., B. J. Karl, R. J. Toft, J. R. Beggs, and R. H. Taylor. 1998. The role of introduced predators and competitors in the decline of kaka (Nestor meridionalis) populations in New Zealand. Biological Conservation 83:175-185.

Wittmann, K., J. J. Vaske, M. J. Manfredo, and H. C. Zinn. 1998. Standards for lethal response to problem urban wildlife. Human Dimensions of Wildlife 3:29-48.

Yore, L. B., and S. Boyer. 1997. College students' attitudes towards living organisms: the influence of experience \& knowledge. The American Biology Teacher 59:558563.

Young, J. C., M. Marzano, R. M. White, D. I. McCracken, S. M. Redpath, D. N. Carss, C. P. Quine, and A. D. Watt. 2010. The emergence of biodiversity conflicts from biodiversity impacts: characteristics and management strategies. Biodiversity and Conservation 19:3973-3990.

Zinn, H. C., and W. F. Andelt. 1999. Attitudes of Fort Collins, Colorado, residents toward prairie dogs. Wildlife Society Bulletin 27:1098-1106. 